\title{
Weathering Characteristics of Building Stone at Ottawa, Canada.
}

\author{
by
}

\begin{abstract}
Matthew Colin Egner
A thesis submitted to the Faculty of

Graduate Studies and Research in partial

fulfilment of the requirements for the degree of

Master of Science
\end{abstract}

Department of Earth Sciences

Carleton University

Ottawa, Ontario

December, 1993

copyright

1993 Matthew C. Egner 
National Library

of Canada

Acquisitions and

Bibliographic Services Branch

395 Wellington Street

Ottawa, Ontario

K1A ON4
Bibliothèque nationale

du Canada

Direction des acquisitions et des services bibliographiques

395, rue Wellington

Ottawa (Ontario)

K1A ON4
Your file Votre rélerence

Our file Notre reference
THE AUTHOR HAS GRANTED AN IRREVOCABLE NON-EXCLUSIVE LICENCE ALLOWING THE NATIONAL LIBRARY OF CANADA TO REPRODUCE, LOAN, DISTRIBUTE OR SELL COPIES OF HIS/HER THESIS BY ANY MEANS AND IN ANY FORM OR FORMAT, MAKING THIS THESIS AVAILABLE TO INTERESTED PERSONS.
L'AUTEUR A ACCORDE UNE LICENCE IRREVOCABLE ET NON EXCLUSIVE PERMETTANT A LA BIBLIOTHEQUE NATIONALE DU CANADA DE REPRODUIRE, PRETER, DISTRIBUER OU VENDRE DES COPIES DE SA THESE DE QUELQUE MANIERE ET SOUS QUELQUE FORME QUE CE SOIT POUR METTRE DES EXEMPLAIRES DE CETTE THESE A LA DISPOSITION DES PERSONNE INTERESSEES.
THE AUTHOR RETAINS OWNERSHIP OF THE COPYRIGHT IN HIS/HER THESIS. NEITHER THE THESIS NOR SUBSTANTIAL EXTRACTS FROM IT MAY BE PRINTED OR OTHERWISE REPRODUCED WITHOUT HIS/HER PERMISSION.
L'AUTEUR CONSERVE LA PROPRIETE DU DROIT D'AUTEUR QUI PROTEGE SA THESE. NI LA THESE NI DES EXTRAITS SUBSTANTIELS DE CELLECI NE DOIVENT ETRE IMPRIMES OU AUTREMENT REPRODUITS SANS SON AUTORISATION. 


\section{ABSTRACT}

Studies have focused mainly on the deterioration of building stone specific to the environments of Europe and the United States, but little information is available on the weathering characteristics of building stone in Canada. Several prominent buildings in Ottawa have needed replacement or restoration due in part to the choice of stone used in relation to the environmental conditions. The Parliament buildings are mostly constructed with sandstone from Nepean, Nova Scotia, and Ohio, and display various features and rates of weathering due to the diverse assemblage of rock types and configuration of the buildings. The most common and detrimental process is salt crystallization, which results in spalling. Halite is the principal salt near ground level and close to entryways, whereas gypsum is dominant higher up on the building where exposure is obscured. A thin black coating of iron compounds and carbon soot is common on many blocks, especially those close to ground level or where the block is angled so to retain snow and flowing water. The Victoria Museum is similar to the Parliament buildings, but displays a cleaner facade. Weathering due to wind direction is well represented by spalling and pitting along the inner side of Wallace sandstone blocks which form chimneys. The former Daly building (demolished in 1991) had developed serious internal fractures from water penetration along stylolites and irregular bedding. Most of the weathering characteristics are directly attributable to environmental responses to these sedimentary structures. Weathering features correlate reasonably well with the physical characteristics, including responses to freeze/thaw and wet/dry cycle tests. Indiana limestone demonstrated the greatest mass loss under experimental conditions. Although not the most absorbent or porous rock, the fraction of fine pore sizes is high, proving that pore size is a significant contributor to weathering rates. Increasing resistance to weathering in the Ottawa area, after Indiana limestone, is shown by, respectively: Ohio sandstone, Wallace sandstone, granite, other limestones, Nepean sandstone, and finally, mafic intrusive rocks. Core from local drill holes indicate that the lower beds of the Nepean sandstone are most suitable for replacement rock, due to the thick bedding, low porosity and high quartz content. Although limestone contains fractures, seams, and/or stylolites over the entirety of the Ottawa Group, a section which correlates with the Lowville to Hull Formations of the Ottawa Group, might provide suitable building stone, if shaly lenses and stylolites are avoided. 


\section{ACKNOWLEDGEMENTS}

The author would like to thank several people and organizations who contributed time, effort and data to this thesis. If it were not for the persistence and support of Dr. J.A Donaldson, this thesis would not even have been initiated. (In turn, his interest in the weathering of building stone was initiated through a collaborative study with Dr. G. Suter, Civil Engineering Department, Carleton University).

Thanks are owed to: Patty Grattan-Bellew, National Research Council, for his time in helping develop ideas for experiments and analyses, as well as support for the pore size analyses; Gordon Bernius, Geological Survey of Canada (GSC), for geophysical data and interpretations; Steve Fruen for providing me with access to the GSC core library and assistance in finding appropriate drill core; Tomm Dann at Environment Canada for supplying me with information on pollution statistics and their interpretation; Luigi Mysak at CANMET for allowing me into the Bells Corners Quarry; Mario Pietrantonio at the Tile Centre who provided me with various samples of representative stone-types; Don Nixon of Public Works for his insight into the structural aspects of the Parliament Buildings; Marcel Joannise, Public Works stone mason, for providing me with generous samples from the Parliament Buildings and for transmitting his knowledge of the stone types; Peter Jones for microprobe interpretations; Ron Conlon for X-ray analyses and identifications; Joseph Van Blockland and Zongsei Deng for helping me with "C" programming; Mr. A. Raffler for supplying me with his personal depth micrometer; Doctors Fred Michel, Ian Clark, and Marg McCully for their editing and input; and finally my family and friends for their support. 


\section{TABLE OF CONTENTS}

Acceptance Sheet II

Abstract III

Acknowledgements $\quad$ IV

Table of Contents $\quad \mathrm{V}$

List of Tables and Figures $\quad$ VII

List of Plates $\quad$ IX

List of Appendices $\quad \mathrm{X}$

Chapter 1. Introduction

1.1 General ......................................................................... 1

1.2 Purpose and method of study ……………........................ 2

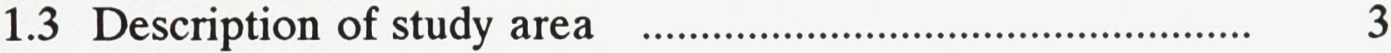

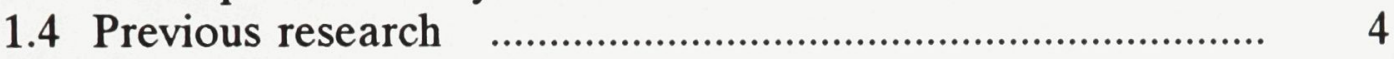

Chapter 2. Weathering

2.1 Physical weathering ………................................................. 9

2.2 Chemical weathering ………............................................... 13

2.3 Biological weathering ……………….................................. 16

Chapter 3. The Environment

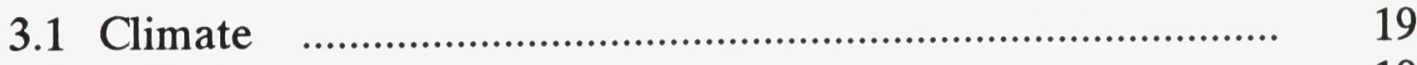

3.2 Pollution ........................................................................... 19

Chapter 4. Building Stone Data

4.1 History of building stone in Ottawa ……............................ 34

4.2 Stone types and specifications ……………....................... 36

4.3 Analytical tests ................................................................ 58

4.4 Scanning Electron Microscopy ……………........................ 75

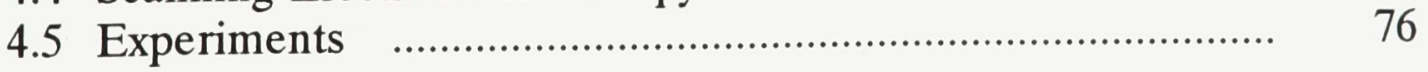


Chapter 5. Weathering Features

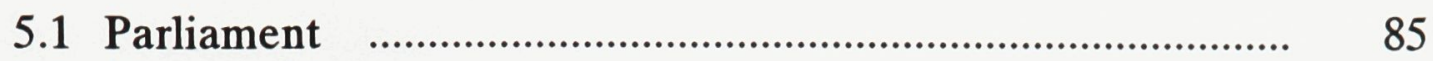

5.2 Victoria Museum ……...................................................... 94

5.3 Daly Building ………......................................................... 95

5.4 Notre Dame Cemetary ……………..................................... 97

Chapter 6. Discussion of Results

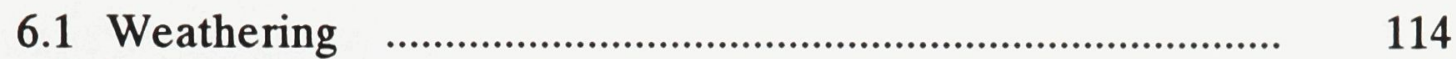

6.2 Replacement material ….................................................... 124

6.5 Preservation ...................................................................... 126

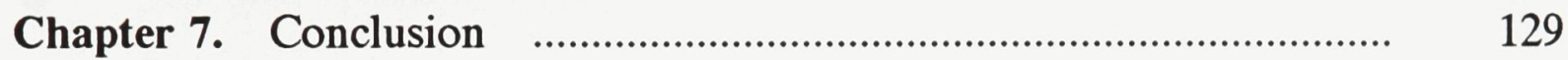

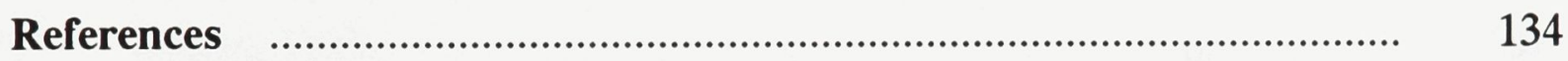

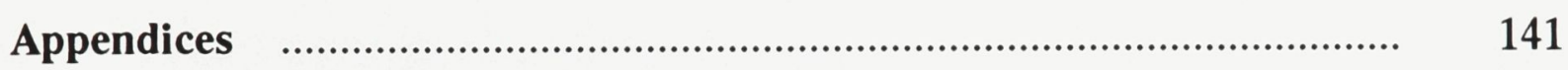




\section{LIST OF TABLES AND FIGURES}

TABLES

PAGE

1. The Climate of Ottawa, Canada f............................................. 20

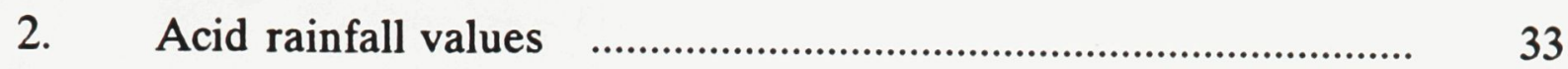

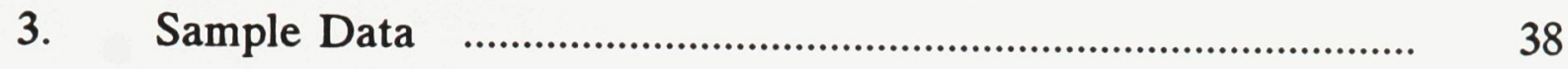

\section{FIGURES}

1. Sulphur Dioxide Levels _......................................................... 22

2. Carbon Monoxide Levels _........................................................ 23

3. Nitrogen Dioxide Levels _................................................... 24

4. Ozone Levels _.................................................................... 25

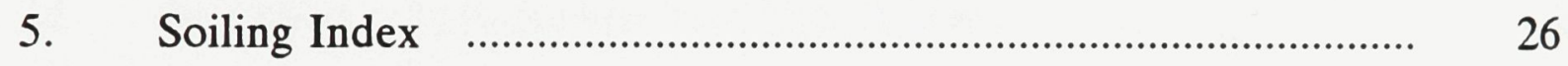

6. Total Suspended Particulate Matter ……................................ 27

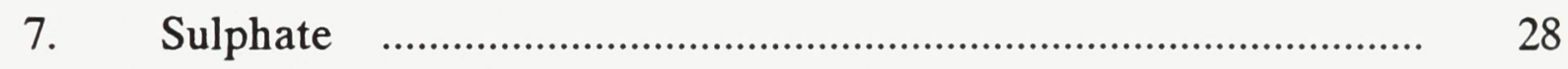

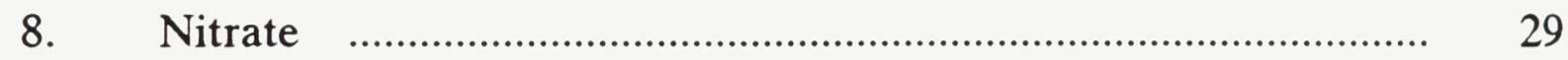

9. Average Bulk Specific Gravity _................................................. 61

10. Bulk Specific Gravity for ASTM Samples ……........................ 62

11. Bulk Specific Gravity - Results and Accuracy _.......................... 63

12. Absorption - First Sample String ………................................ 64

13. Absorption - Second Sample String …….................................. 65

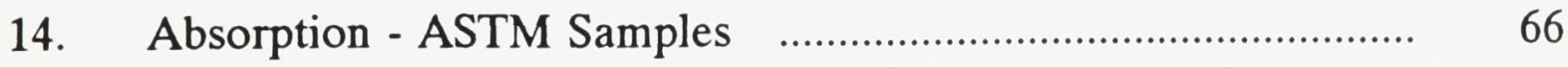




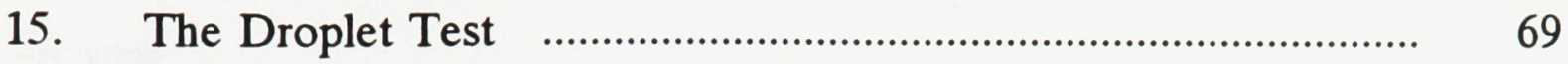

16. Pore Size Distribution (PSD) - Nepean Sandstone $\quad$.................. 70

17. PSD - Wallace Sandstone _.........................................................

18. PSD - Ohio Sandstone …......................................................... 72

19. PSD - Indiana Limestone _........................................................ 73

20. PSD - Coburg Limestone _...................................................... 74

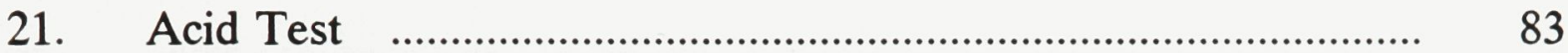

22. Experiments With Salt ……………......................................... 84

23. $\mathrm{pH}$ Level of Moss and Mortar ……......................................... 93

24. Correlation of Properties and Experiments _............................ 121

25. Correlation of Deterioration with Pore Size …....................... 122 
1. Optical microscopy: samples 1 and 2 ....................................... 40

2. Optical microscopy: samples 3 and 4 ...................................... 42

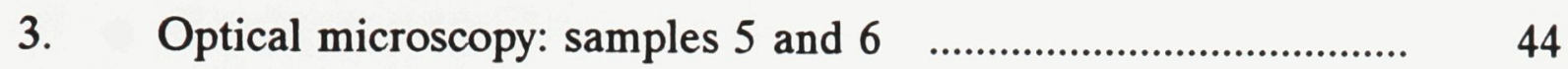

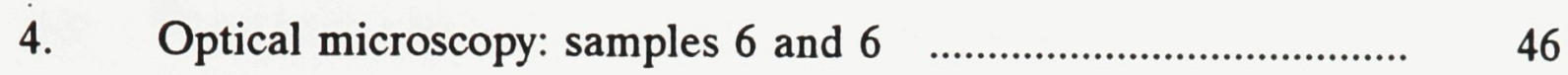

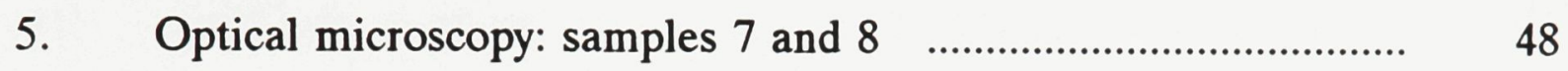

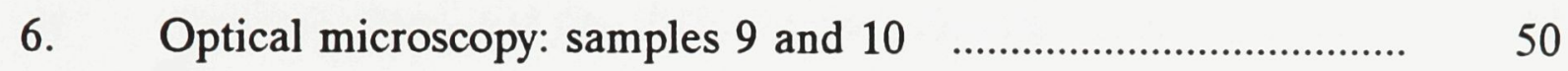

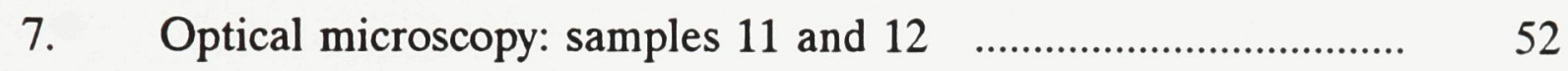

8. Optical microscopy: samples 13 and 14 .................................... 54

9. Scanning electron microscopy: gypsum effluorescence $\quad \ldots \ldots \ldots . . . . \quad 80$

10. Scanning electron microscopy: black crust on sandstone $\quad \ldots \ldots . . . \quad 82$

11. Photography: differential weathering of Nepean sandstone and spalling of Wallace sandstone $\quad$...................................................... 101

12. Photography: influence salt on Ohio sandstone and mortar cappings on Wallace sandstone

13. Photography: gypsum scaling in a gable and iron oxide weathering in granite

14. Photography: soot accumulation and direction $\ldots \ldots \ldots \ldots \ldots \ldots \ldots \ldots \ldots . . . . . . . . . .107$

15. Photography: Soot lines at cornice and moss weathering $\ldots . . . \quad 109$

16. Photography: weathering At the Victoria Museum …............ 111

17. Photography: Daly building stone, and deterioration from a nearby Ottawa limestone building 


\section{LIST OF APPENDICES}

\section{APPENDIX}

PAGE

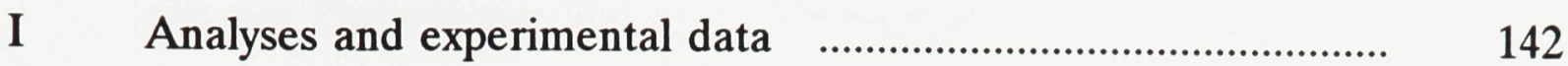

II Headstone algorithm and data f.............................................. 148

III Drill hole logs _................................................................... 155

IV Drill hole sections _.................................................................. 177

V Building plans and the Bells Corners Quarry $\quad \ldots \ldots \ldots \ldots \ldots \ldots \ldots \ldots \ldots . . . . . . . . . . . . .194$ 


\section{Introduction}

\section{$\underline{1.1 \text { General }}$}

Ottawa, Ontario was first settled by Europeans in the late 1700s. At that time, buildings were crudely fashioned from logs and lumber due to the Land Vestige Act which deterred people from building any permanent structure that could easily be appropriated by the crown. In 1821 , the law was changed to protect landowners and builders, from which time stone buildings were constructed.

The oldest remaining stone building in Ottawa is the Bytown Museum, previously called the Commissariat Building, located alongside the canal just east of Parliament. This structure was built by Thomas McKay in 1827 as a storehouse and office for canal barges. The stone is limestone taken from the site.

Since that time, stone became an important building material, first for durability and comfort, and later for the decorative charm. Many buildings in lowertown were constructed of local limestone, but most have since been either destroyed or renovated.

Robert Skead, of Nepean, recognized the value of Nepean Sandstone in the mid 1800s and began quarrying the stone for houses and roadways. For reasons of appearance and durability, this stone was chosen for use in the Parliament buildings and later for several other government buildings. In addition to the local limestone and Nepean sandstone, several other rock-types were used in these buildings.

More recently, granite and anorthosite have been used extensively for facades in private and public buildings. These facades tend to be very thin relative to stone 
building blocks, and their local weathering properties are as yet unknown.

It is important to know the geological characteristics of different rock types in order to assess their potential for weathering. Stones that have been employed in local buildings over a period of time display weathering features, and can be compared in a relative way. Due to the numerous variables involved in weathering, duplication of weathering cannot be absolutely reproduced in a laboratory. However, through petrography, chemical analyses, laboratory experiments, and qualitative analysis, several conclusions about weathering agents, features, and performance can be made.

Building stone is continually weathering through mechanical and chemical means, diminishing structural integrity and appearance. This thesis attempts to address: the manner in which stone weathers; relative rates of weathering and performance; agents of weathering; degree of weathering in Ottawa buildings; preservation of stone; and replacement materials. Although the structural properties of stone are known, geological properties have been overlooked as an important aspect of degradation.

\subsection{Purpose and method of study}

The purpose of this study has been to assess the effects of weathering on the appearance and performance of building stone used in the Ottawa area, and to suggest solutions to recent problems related to the stone. The methods by which this has been accomplished are: visual examination of local buildings, analysis of the 
the properties of the various types of stone used, and experimentation to simulate some weathering characteristics. Samples of various types of common building stone were collected and examined for mineralogical and textural properties. Analyses were performed to determine the absorptive properties, and experiments tested the relative durability of each stone type by means of freezing and thawing with salt water, wetting and drying with salt water, and vulnerability to acids. Drill core was examined to better understand the relationship between rock durability and stratigraphy, and to suggest suitable replacement material sources.

\subsection{Description of study area.}

Because of the concentration of buildings that are prominent and relatively old, the downtown core of Ottawa was chosen for this investigation. Emphasis was placed on buildings which are famous and have also been the focus of some recent structural distress. Three main buildings were chosen on the basis of these criteria: Parliament, the Victoria Museum, and the Daly Building. Other buildings are mentioned due to their historical significance, the type of stone involved, or as a comparison to the buildings studied.

All of the buildings are bounded by the Ottawa River to the north, the Queensway to the south, Bronson Avenue to the west, and King Edward Avenue to the east. Rock samples for the Parliament Buildings were primarily collected at the workshop of the stonemason located at Plouffe Park, Wellington Street. Other samples were collected at the site of the former Daly Building, Parliament Buildings, 
Victoria Museum, Notre Dame Cemetery, and The Tile Centre Company on Carling Avenue.

In addition to buildings, core from drill holes around the Ottawa region was examined to gain a better understanding of the variations in Nepean sandstone and local limestone, and to locate possible replacement stone for renovations. At the moment, no Nepean Sandstone is being quarried. Borehole locations are generalized due to poor records of actual siting. Drill hole core was logged at the Geological Survey of Canada Core Library located at Tunneys Pasture and Hull. In addition, outcrops were examined within the Bells Corners (CANMET) quarry.

\subsection{Previous research}

Although much has been written on the weathering of rocks and minerals, less has been written on the effects of weathering on stone used for building. Virtually no previous research has been carried out on the weathering effects of building stone in Ottawa. Most weathering research has emphasized the effects of water on expansion of rocks, mineral alteration, frost in porous systems, and salt crystallization in porous systems.

The foremost authority on building stone weathering is Erhard Winkler. Winkler has written many papers on the impact of weathering on stone buildings in the United Kingdom and the United States. John Ashurst is also a leading authority on building stone and architecture as a research architect with the Directorate of Ancient Monuments and Historic Buildings, Government of the United Kingdom. 
Much of Winkler's and Ashurst's research papers were written in the 1970s, when the preservation of historic buildings rose to prominence.

Hudec (1975) outlined the correlation of rock weathering parameters. Weathering is ascribed to two distinct factors: water and temperature. Hudec emphasized that the porosity of a rock has significant direct and indirect effects on rock properties.

Hudec and Sitar (1975) reviewed the effects of water sorption on carbonate expansivity. The authors concluded that the moisture content has an effect on the thermal expansion of the rock, and that a rock could expand isothermally through changes in moisture content. The soundness of a rock could depend on this isothermal expansion effect.

Litvan (1975) showed that with all $\mathrm{NaCl}$-impregnated water solutions in porous cement paste, two exothermic reactions take place upon freezing: the first at $-8^{0} \mathrm{C}$ for pure water and slightly lower depending on the concentration of salt; the second is invariant at $-22^{\circ} \mathrm{C}$, which is the eutectic point of the solution. Salt solutions of low concentration (3-5\% according to Verbeck and Klieger, 1956) are the most damaging to rock scaling due to the blocking effect in pores. When the salt content of exuded solutions freeze on the surface or outer portion of a pore channel, the pores are blocked and thermodynamic equilibrium cannot be attained without damage.

Jerwood, Robinson and Williams (1990) performed frost and salt weathering experiments on chalk in order to determine temperature and concentration effects. 
As in previous studies, the authors found that a low $(5.5 \%) \mathrm{NaCl}$ concentration was more detrimental than a high $(12.5 \%)$ concentration. $\mathrm{NaCl}$ solutions are most destructive under very cold $\left(-30^{\circ} \mathrm{C}\right)$ regimes; however, $\mathrm{NaSO}_{4}$ alone or combined with $\mathrm{NaCl}$ in solution is damaging under mild or cold regimes. $\mathrm{MgSO}_{4}$ inhibits the breakdown of chalk cubes under intense freezing conditions.

Maage (1975) studied the influence of pore size distribution in bricks on frost resistance. From experiments, a linear relation was observed between the frost resistance and the inverse value of the intruded pore volume. Maage concluded that frost resistance is proportional to the volume of pores greater than 3 um in diameter.

Sharp and others $(1982,1989)$ performed a study on the balustrade of St. Pauls Cathedral, London, England, in which weathering rates were measured with a micro-erosion meter. The purpose of the study was to determine if weathering rates change with time. The conclusion was that weathering rates have neither increased nor decreased, but have remained constant in an environment of decreasing $\mathrm{SO}_{2}$ levels but increasing $\mathrm{NO}_{2}$ levels.

Several studies were performed on buildings and monuments to determine rates and features of weathering. Dragovich (1987) evaluated the weathering of marble monuments and the effect of acid rain in urban areas.

Winkler (1987) discussed the various factors of weathering on buildings in the eastern United States, and reports on some of the features in the stone test wall erected in 1948 by the National Bureau of Standards in Washington, D.C. The wall is composed of 2352 blocks of stone from quarries in the U.S.A and Europe. Indiana 
limestone, which tops the wall and is exposed to the north and south, developed a definite relief between the matrix and fossil fragments. Some of the sandstone blocks show crumbling of the surface and spalling along bedding planes.

Xidakis and others (1990) described weathering features in Greece. Gauri (1990) described the decay of, and the preservation techniques for, famous stone buildings around the world. Bell and Coulthard (1990) addressed preservation techniques in the United Kingdom. Attewell and Taylor (1990) discussed the rate of weathering at Durham Cathedral, England. Livingston and Baer (1990) commented on the use of tombstones as a research tool for weathering of stone. Kertesz (1990) studied the decay and conservation of stone in Hungary.

Goossens and others (1989) investigated the effects of acid on the surface of feldspar. Ballantyne and others (1989) examined the impact of weathering under latelying snow patches.

Three important papers have been written on the effects of biologica on rocks. Schenk and others (1989) report on accelerated silicate weathering due to organic substances. Experiments were conducted using salicylic, tartaric, and citric acids. Complex-forming organic ligands are adsorbed and result in higher concentrations of dissolved aluminum in solution.

Cooks and Otto (1990) observed by means of scanning electron microscopy and X-ray fluorescence that lichen (Lecidea aff. sarcogynoides) contributes to the chemical weathering of Magaliesberg quartzite by chelation and by physical weathering through hyphae penetration. 
Dorn (1989) outlined the importance of biological weathering; in a subsequent paper (1990), he discussed the character of rock varnish, noting high concentrations of iron or manganese of biological origin. 


\section{Chapter 2. Weathering}

\subsection{Physical weathering.}

Physical weathering is the degradation of rocks and minerals by means of mechanical methods which exert stress on the cohesion of the material and result in rupture. Physical weathering can be caused by either external forces or internal stress. The main physical factors which control rock weathering are (Winkler, 1973):

1. frost and ice formation

2. salt crystallization

3. pressure release

4. chemical changes

5. thermal expansion

6. moisture content

7. abrasion

The seven factors listed above work to different degrees, depending on the environment, and result in characteristic weathering features. Some features are shared by more than one mode of weathering; the most commonly observed degradation features are (Winkler, 1973):

1. sheeting and spalling 
2. honeycomb

3. fracturing

4. plucking

5. discoloration

6. etching

7. efflorescence

Sheeting is a response to released stress on a given rock face. The resulting pattern is a set of sheets that develop by way of fractures parallel to the rock face. Spalling is the same response but involves the rupture and removal of fragments as flakes of various shapes. Spalling can be produced by release of stress, crystal growth, or moisture swelling.

Crystal growth, the most detrimental agent of rock weathering in building stone, includes salt crystallization, ice formation, and chemical alteration of minerals. In each circumstance, a significant volume change occurs as crystals grow and the stresses on the rock can easily fracture grains and grain boundaries.

With the exception of saline solutions, ice formation is the most detrimental physical weathering agent. During freezing, water expands 9\% (Ollier, 1969) and theoretically, pressures of $30,000 \mathrm{lb} / \mathrm{in}^{2}$ can be obtained at $-22^{\circ} \mathrm{C}$ in a confined space. Most rock pores and fractures are not confined; however, with the combination of surface ice formation (sealing in the core water) and supercooling of inner water, a confined system can be simulated. Frost can act directly or indirectly to break down 
rock. Directly, ice formation causes expansion in pores and cracks, wedging apart the grains. Indirectly, the repetition of freeze and thaw causes disorder of particles during contraction to the original form.

The destruction of rock by pure water has been well studied by Dunn and Hudec (1966), and Hockman and Kessler (1950). Dunn and Hudec surmised that the destruction by pure water is due to expansion of sorbed and ordered water. Hockman and Kessler suspected that rapid wetting and drying cause rock destruction. Griggs (1936) determined that rock bursts, commonly thought to be the consequence of thermal expansion of minerals, are actually the result of capillary moisture expanding within the pores of the rock.

The combination of moisture and salts causes the most damage in rock disintegration. Moisture is derived from the atmosphere and the ground. The transport of moisture and ions within a rock depends on the available pore space and pore size. Moisture fills the rock by way of condensation and penetration. The more water in a capillary system, the greater the travel ability. The greater the relative humidity, the greater the capillary condensation. Vos (1969) performed experiments with clay bricks exposed to various concentrations of $\mathrm{NaCl}$ at different relative humidities. Although the behavior of bricks may differ from natural stone, his data indicate that higher concentrations of salt produce greater hygroscopic moisture content at lower relative humidities.

Kaiser (1929) performed an experiment with sandstone from the Regensberg Cathedral, England, in which layers at $5 \mathrm{~cm}$ intervals were removed and the salt 
content $\left(\mathrm{SO}_{4}\right)$ measured. Salt migration to the surface was clearly evident, and the salt content dropped off rapidly within a few centimetres below the surface. Kaiser also made two other important observations. The density of the rock increased at the surface, especially for soft and friable rock. Secondly, the amount of gypsum plus calcium sulphite is greater on surfaces that are exposed to light.

Salt which moves to the surface of rock and crystallizes at the outlet of capillaries forms a white powdery efflorescence. Efflorescence indicates the presence of salts and moisture movement. Subflorescence is salt produced by crystallization just below a thin skin of sooty crust, and results in the loosening and removal of the surface crust. Along with the crystallization of salt, hydration can lead to pore wall pressure and disruption. Hydration pressures of some prominent salts were calculated by Winkler and Wilhelm (1970) for various temperatures and relative humidities. The hydrates of $\mathrm{CaSO}_{4}$ and $\mathrm{NaCO}_{3}$ were observed to exert enough pressure to cause deterioration of rock, whereas the hydrates of $\mathrm{MgSO}_{4}$ exerted low pressures. Low temperatures and high relative humidities create the greatest amounts of internal pressure.

Some salts exhibit a high degree of differential expansion within a rock. $\mathrm{NaCl}$ is one such mineral. Cooke and Smalley (1968) demonstrated that with a temperature increase from $0^{\circ}$ to $60^{\circ} \mathrm{C}$, granite will expand by less than $.02 \%$, whereas $\mathrm{NaCl}$ will expand by $0.5 \%$.

Iron in rock from weathering minerals can be mobilized and precipitated as ferric oxide or hydroxide, commonly in rusty bands or rings. The expansion due to 
precipitation can break apart the grains and matrix of the rock. Iron and manganese can also form a thin coating on rock analogous to "desert varnish". The origin of desert varnish has been reported to be biological (Dorn, 1990); others however, report it to be inorganic (Smith and Whalley, 1988). Both factors probably contribute to the buildup of desert varnish.

\section{$\underline{2.2 \text { Chemical weathering. }}$}

Chemical weathering is governed by Le Chatelier's principle: a system in equilibrium will respond to re-establish equilibrium if stress is applied. Two important factors involved in chemical weathering are the course of a reaction and the rate of the reaction. The course of reaction often depends on removal of material. The rate can be regulated by removal of weathering products, and also by the environment. Removal of the product maintains an open system and the reaction can continue. If the product is not removed, the system becomes closed and equilibrium is reached, terminating the reaction.

Important variables to reactions are $\mathrm{pH}, \mathrm{Eh}$, and ionic potential. The $\mathrm{pH}, \mathrm{a}$ measure of $\mathrm{H}^{+}$ion concentration, controls the solubility of most ions, and is therefore important with respect to acid rainfall. These controls on chemical reactions determine the type of weathering in a specific environment. The main types of chemical weathering are solution, oxidation, reduction, hydration, hydrolysis, carbonation, and chelation.

Chemical weathering of building stone can be arranged around the two main 
groups of minerals that form the rock types, silicates and carbonates. Although the chemical composition of a mineral is the principal determinant of weathering, crystal structure, size, and shape also play important roles. Hence, two mineral grains with the same or similar chemical composition could weather quite differently if their grain sizes, crystal structures and/or shapes differ.

Water acts on silicate structures to replace cations with $\mathrm{H}^{+}$ions, oxidize ferrous to ferric ions and then hydrate the remaining unstable material. Depending on the $\mathrm{pH}$ of the water, the hydroxyl groups can easily be removed in solution. Stitcher and Bach (1966) summarized silicate weathering in terms of a set of stability trends.

Chemical weathering of silicate rocks is controlled by solubilization of ions from silicate minerals. This in turn loosens and liberates ions so that they can be removed in solution. Openings in the lattice are then exposed to hydration. Hydrogen ions permeate the surface of a mineral and corrode the silicate structure. Silica and cations are detached and removed by leaching. The remaining aluminum, potassium, silicon, oxygen and hydrogen ions can recombine to form clay minerals. Amongst the feldspars, albite leaches faster than orthoclase. In tests of silicate minerals for rates of leaching, Keller et al. (1963) determined that leaching rates are doubled for Ca, $\mathrm{Mg}, \mathrm{Na}$, and $\mathrm{K}$ in $\mathrm{CO}_{2}$-rich water compared to distilled water. Dennen and Anderson (1962) demonstrated that temperature and relative humidity are more important factors in the above-ground weathering of silicate minerals than is the composition of the rock. 
The degree of weathering is calculated for igneous rocks by the "abrasion $\mathrm{pH}$ " value (Grant, 1969). This estimate is based on the amount of $\mathrm{H}^{+}$ions within the rock. In general, the more acidic that a rock is, the more kaolinite clay content there is, indicating a greater degree of weathering.

Carbonate rocks are chemically weathered by solution; the solubility of carbonates is controlled by temperature and by $\mathrm{pH}$ (which is greatly influenced by the amount of $\mathrm{CO}_{2}$ in the solvent). The process of solution is greatly enhanced when $\mathrm{CO}_{2}$ combines with water to form $\mathrm{H}_{2} \mathrm{CO}_{3}$ through the following reaction (Winkler, 1973):

$$
\begin{aligned}
& \mathrm{H}_{2} \mathrm{O}+\mathrm{CO}_{2}-\cdots>\mathrm{H}_{2} \mathrm{CO}_{3} \\
& \mathrm{H}_{2} \mathrm{CO}_{3}+\mathrm{CaCO}_{3} \ldots->\mathrm{Ca}\left(\mathrm{HCO}_{3}\right)_{2}
\end{aligned}
$$

Winkler (1966) observed that, for a cool climate and $889 \mathrm{~mm}$ of rainfall per year, approximately $1.5 \mathrm{~mm}$ of surface reduction has occurred over 50 years for headstones in South Bend, Indiana, U.S.A. Loughlin (1931) reported 3.14mm of surface reduction over 100 years for $109 \mathrm{~mm}$ of rainfall in New York, U.S.A. Others have cited weathering rates for carbonates as follows:
Marble, S. Australia (Cann, 1974)...
$0.1 \mathrm{~mm} / 100$ years
Limestone, Belgium (Kupper, 1975).. $\quad 0.25 \mathrm{~mm} / 100 y e a r s$
Limestone, Haifa, Israel (Klein, 1984)... $0.5 \mathrm{~mm} / 100$ years
Marble, U.K. (Attewell et al., 1990)... 0.2-1.4mm/100years (range) 
Kaye (1957) showed that the motion of a solvent is a significant factor in carbonate dissolution. An exponential increase in flow rates results in a linear increase in dissolution. A stagnant solvent will become saturated with ions and reach equilibrium with the adjacent rock, but a constant stream of flow continues to remove ions from the system.

\subsection{Biological weathering.}

In biological weathering, both physical and chemical disintegration can be promoted by the presence and activity of living organisms. Although most living organisms can have an effect on stone, only some produce a significant effect. Bacteria, moss, lichen, and birds cause the greatest amount of damage.

Bacteria can be grouped as either autotrophic or heterotrophic. Heterotrophic bacteria obtain energy from organic matter released by plants and lichens, and so cause little damage to stone. Autotrophic bacteria derive energy from the sun and Eh or $\mathrm{pH}$ reactions. These bacteria can be further subdivided as nitrogen-fixing, sulphur, or iron bacteria.

Kauffmann (1960) established that some autotrophic bacteria attack carbonate rocks by nitrification through the following reaction:

$$
2 \mathrm{CaCO}_{3}+\left(\mathrm{NH}_{4}\right)_{2} \mathrm{SO}_{4}+4 \mathrm{O}_{2}=\mathrm{Ca}\left(\mathrm{NO}_{3}\right)_{2}+\mathrm{CaSO}_{4}+2 \mathrm{CO}_{2}+4 \mathrm{H}_{2} \mathrm{O}
$$

This process adds to the natural formation of gypsum on carbonate rocks. 
Sulphur bacteria can convert sulphur to sulphate by secreting an oxidizing solution. Millot and Cogne (1967) identified Thioballicus thiooxidans (a common sulphur bacteria) on stone surfaces ranging in numbers from several thousand per gram of rock to one million. However, Voute (1969) reported several million per gram on tropical rock surfaces.

Ferrobacillus ferroooxidans and Thiobacillus ferrooxidans are the most common iron bacteria that act to oxidize pyrite and other sulphides to release sulphuric acid.

Moss grows where there is moisture, shade, and a mineral component. The lower north-facing side of a stone wall is ideally suited to moss growth, as long as the moss can attach a root. Mosses have a tendency to prevail along fractures in the mortar due to the water retention and friable nature of the mortar. As the moss grows, it wedges the mortar out and permits water flow. Although this is more common in the mortar, fractured and porous rock are also at risk. The effects of moss and other lower order plants on rock is discussed by Schaffer (1932).

Drzal and Smyk (1968) found that fungi and Actinomycetes produce carbonic, nitric, and sulphuric acids in order to break down silicates, especially micas and orthoclase. Silverman and Munoz (1970) determined that the degree of leaching of common elements varies as follows:

$\mathrm{Si}$

$0.3-31 \%$

$\mathrm{Al}$

$0.7-11.8 \%$ 
$\mathrm{Fe} \quad 25-60 \%$

The fungus Penicillium simplicissimum WB-28 was found to secrete nitric acid, which released these elements over a period of 7 days, and the $\mathrm{pH}$ of the solution dropped from an initial 6.8 to 3.5 .

These data indicate the vulnerability of mafic igneous rocks such as gabbro to fungal attack. Although lichens are a significant factor in rock weathering, the polluted urban environment generally prohibits their growth.

Other organisms which contribute to the break-up of rock include birds, plants, and insects. Birds produce various quantities of phosphoric and nitric acids which can promote the formation of gypsum. Plant roots can pry apart component parts of a stone block, increasing the circulation of water and promoting the growth of other organisms. Insects may inhabit crevices in rock, but are probably not a significant factor in weathering. 


\section{Chapter 3. The Environment}

\subsection{Climate.}

Weather statistics for Ottawa are gathererd by Environment Canada approximately $0.4 \mathrm{~km}$ north of the Ottawa Airport terminal building. The airport is about $10.5 \mathrm{~km}$ south of the city centre at latitude $45^{\circ} 19^{\prime} \mathrm{N}$ and longitude $75^{\circ} 40^{\prime} \mathrm{W}$. Instruments are located at an elevation of $114 \mathrm{~m}$ above sea level.

The climate of Ottawa is considered to be cold continental, with large variations in temperature. Important climatic statistics are covered in Table 1 . The maximum temperature recorded at Ottawa was $38^{\circ} \mathrm{C}$ in 1944 and the minimum was $-36^{\circ} \mathrm{C}$ in 1943 . The average low for January is $-15^{\circ} \mathrm{C}$ and the average high for August is $26^{\circ} \mathrm{C}$. The average annual temperature is $5.7^{\circ} \mathrm{C}$. The annual number of freeze/ thaw days for 1992 was 77.

Ottawa receives an average of $662.9 \mathrm{~mm}$ of rainfall and $227.3 \mathrm{~mm}$ of (water equivalent) snowfall per year. The total amount of precipitation averages $890.2 \mathrm{~mm}$ and is fairly evenly distributed throughout the year. The average high annual relative humidity is roughly $88 \%$ and the average low is $50 \%$. In 1992 there were 37 days of fog. In contrast, there were 2008.5 hours of sunshine in 1992 . The predominant wind direction is WNW, with an average velocity of $14.6 \mathrm{~km} /$ hour.

\subsection{Pollution.}

The principal pollutants (1991) are measured by the National Air Pollution 


\section{The Climate of Ottawa, Canada}

\begin{tabular}{|c|c|}
\hline Statistic & Value \\
\hline \hline Average annual rainfall & $662.9 \mathrm{~mm}$ \\
Average annual snowfall (water equiv.) & $227.3 \mathrm{~mm}$ \\
Average annual precipitation & $890.2 \mathrm{~mm}$ \\
\hline Average maximum temperature & $26.3 \mathrm{C}$ \\
Average minimum temperature & $-15.4 \mathrm{C}$ \\
Average annual temperature & $5.7 \mathrm{C}$ \\
\hline Number of freeze/thaw days (1991) & 77 \\
\hline Average annual relative humidity (high) & $88 \%$ \\
Average annual relative humidity (low) & $50 \%$ \\
\hline Number of foggy days (1991) & 37 \\
\hline Predominant wind direction & $\mathrm{WNW}$ \\
Average wind velocity & $14.6 \mathrm{~km} / \mathrm{h}$ \\
\hline Average annual sunshine & $2008.5 \mathrm{hours}$ \\
\hline
\end{tabular}

Table 1. Long term climate statistics for Ottawa. Compiled from Environment Canada, 1991. Averages are from 1951-1980. 
Surveillance division of Environment Canada. Details on data collection and instrumentation are provided by the Environmental Protection Series, NAPS annual summary, 1991.

The main pollutants are $\mathrm{SO}_{2}, \mathrm{CO}, \mathrm{NO}_{2}$, ozone, soot, sulphate, and nitrate. Statistics were gathered for Ottawa and for: Sudbury, ON; Toronto, ON; Windsor, ON; Montreal, QU.; and Saskatoon, SK. These cities were chosen to determine the level of pollution with respect to larger urban centres and more isolated, smaller urban areas. The statistics were then plotted for contrast (Figures 1-8).

$\mathrm{SO}_{2}$ is measured in parts per billion and gauges the amount of gaseous emissions in the air. These emissions are mainly derived from paper mills, smelters, and other industries. From Figure 1, the levels of $\mathrm{SO}_{2}$ at Ottawa are lower than at any of the other measured locations, and one third that of the Toronto level. Sudbury has the highest level of $\mathrm{SO}_{2}$ due to nickel smelting operations, and Windsor the second highest level, possibly due to automotive and other industries from Detroit and nearby centres.

$\mathrm{CO}$, measured in parts per million, is mainly produced by the burning of fossil fuels and wood. In urban areas, cars are the main contributing factor to the levels of $\mathrm{CO}$. Ottawa has the second highest level of $\mathrm{CO}$ for the areas measured, only slightly less than the level for Toronto, and equal to that of Windsor. Sudbury and Saskatoon have much lower levels of $\mathrm{CO}$.

Automobile exhaust also accounts for $\mathrm{NO}_{2}$ emissions. Ottawa has considerably higher levels of $\mathrm{NO}_{2}$ than Sudbury and Saskatoon, but slightly lower levels than 

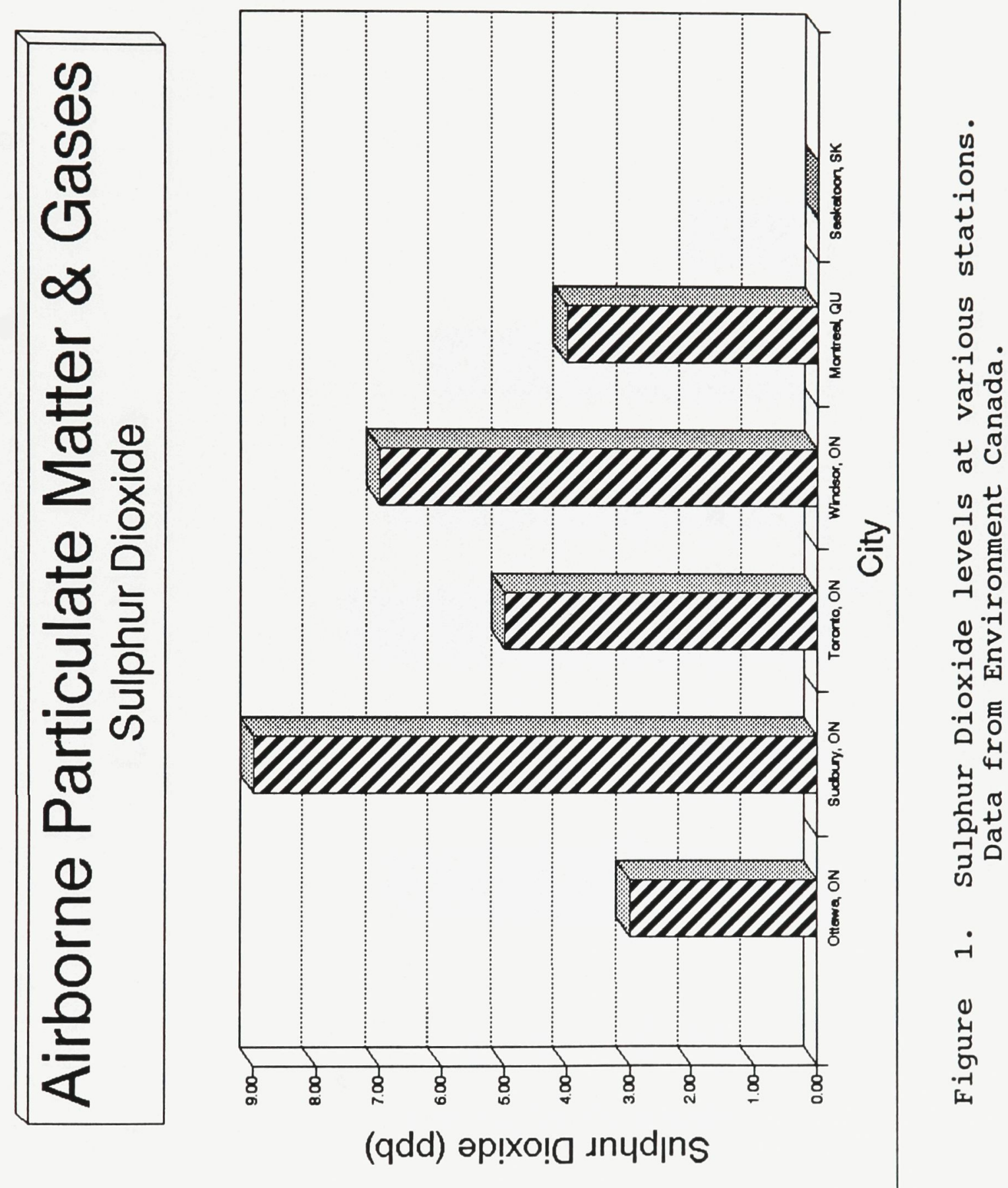


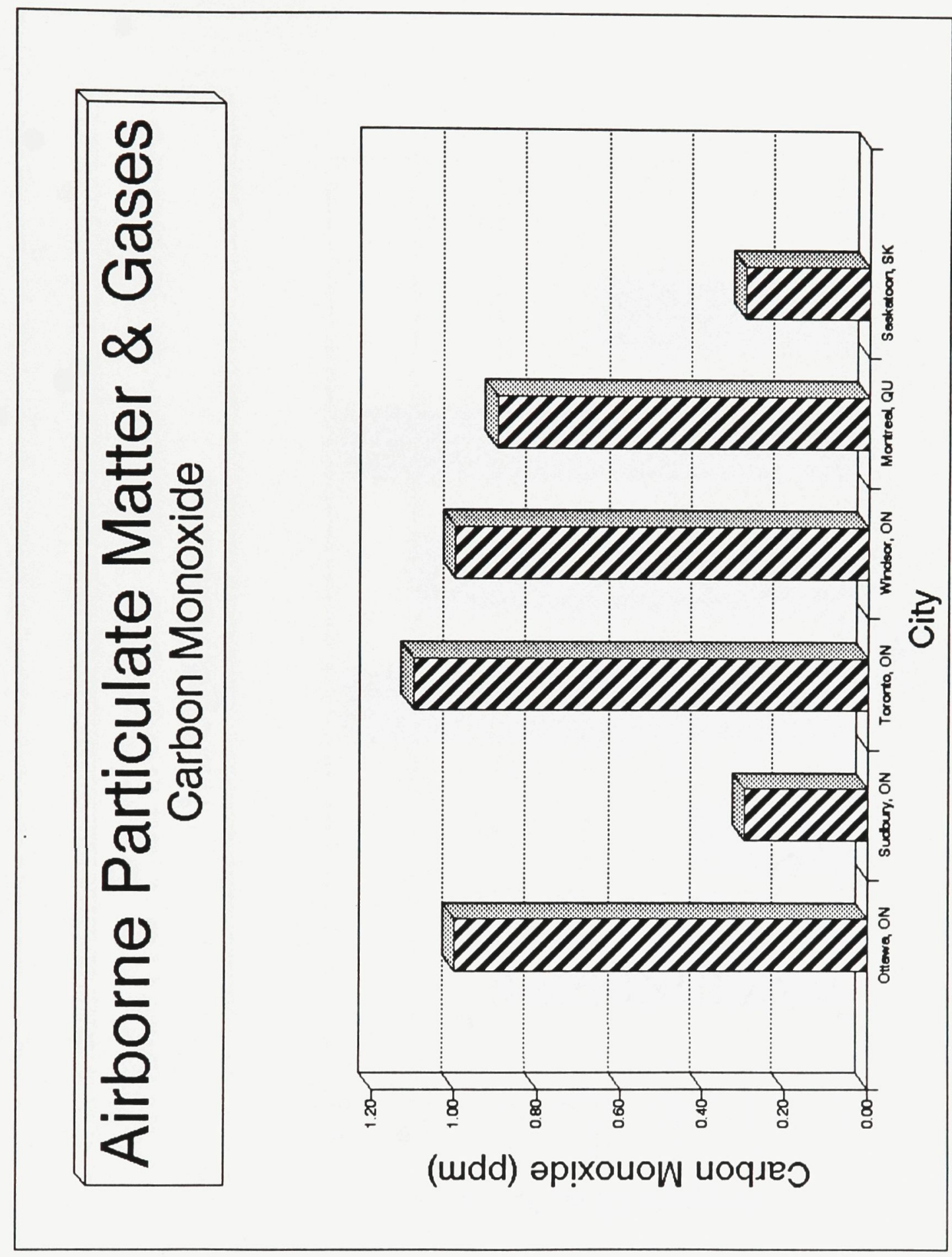

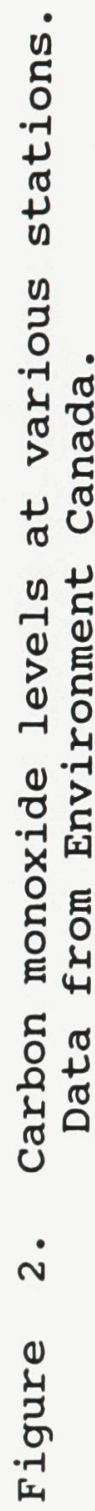



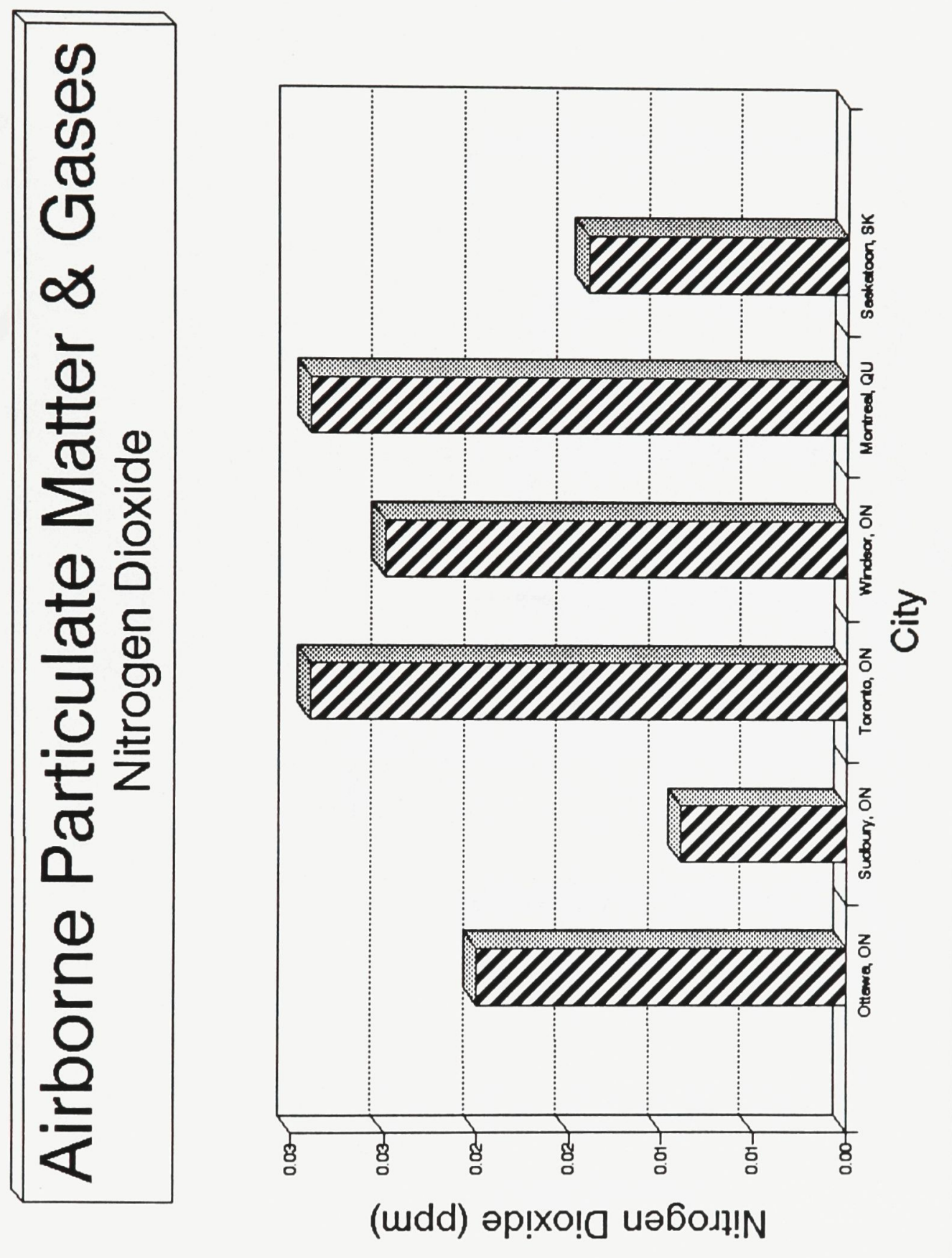

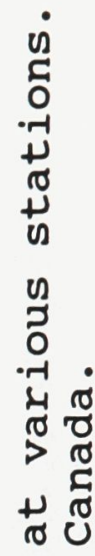

n

닫

$>$ E

(1)

(1).

?

-

O

겅 트

ट 4

(1)

ช

다

$+$

$\dot{m}$

वृ 


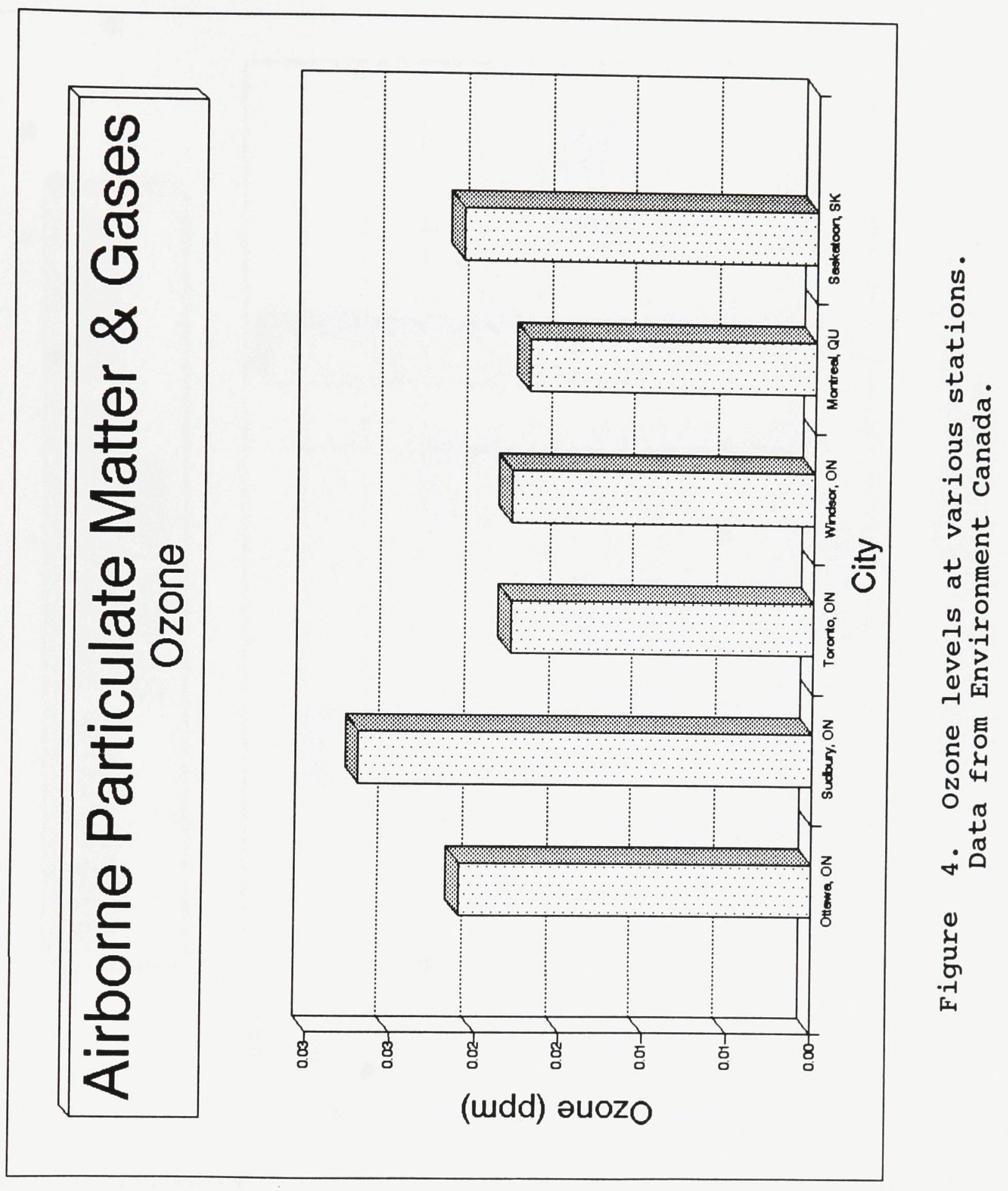




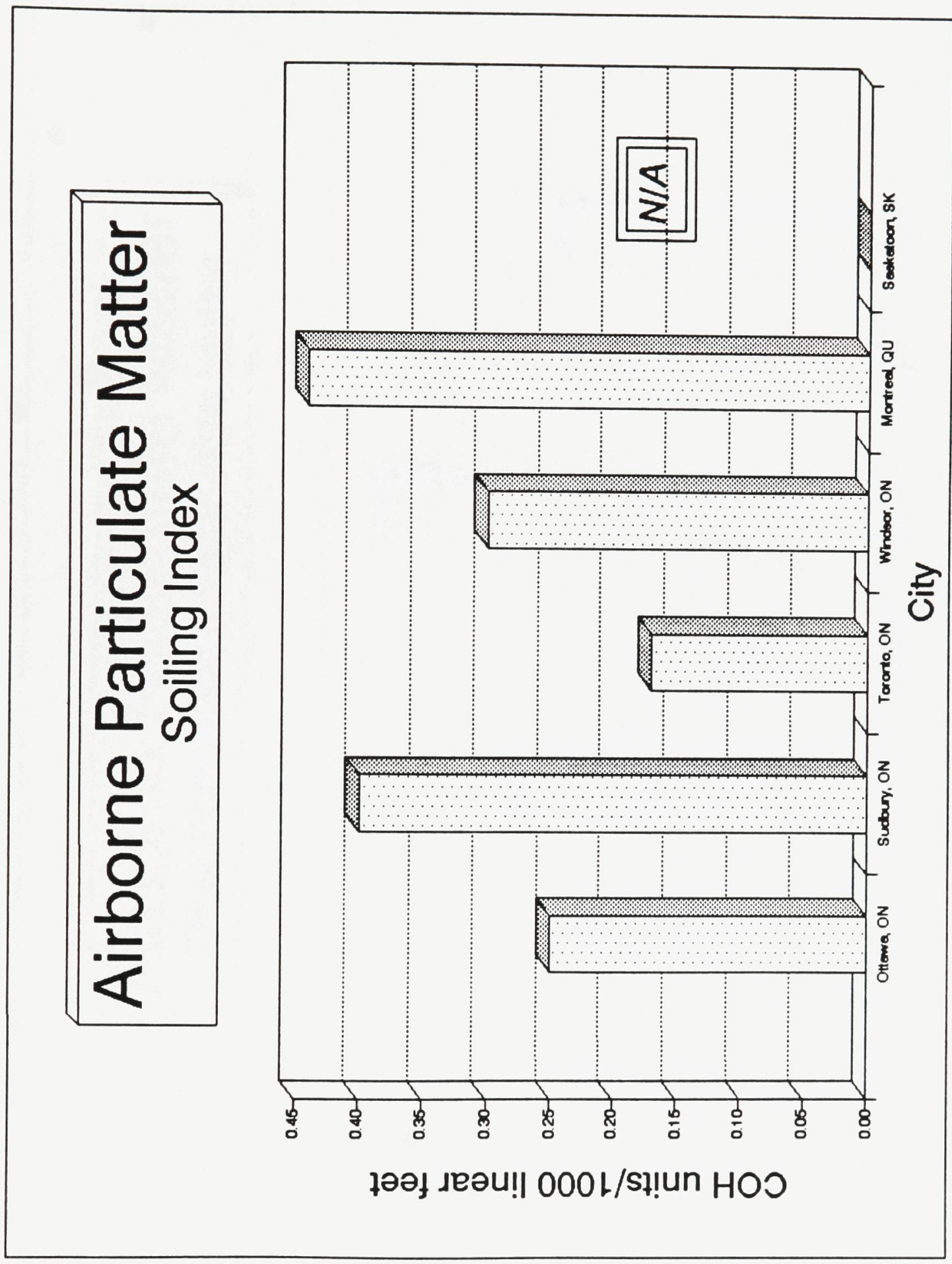

D 

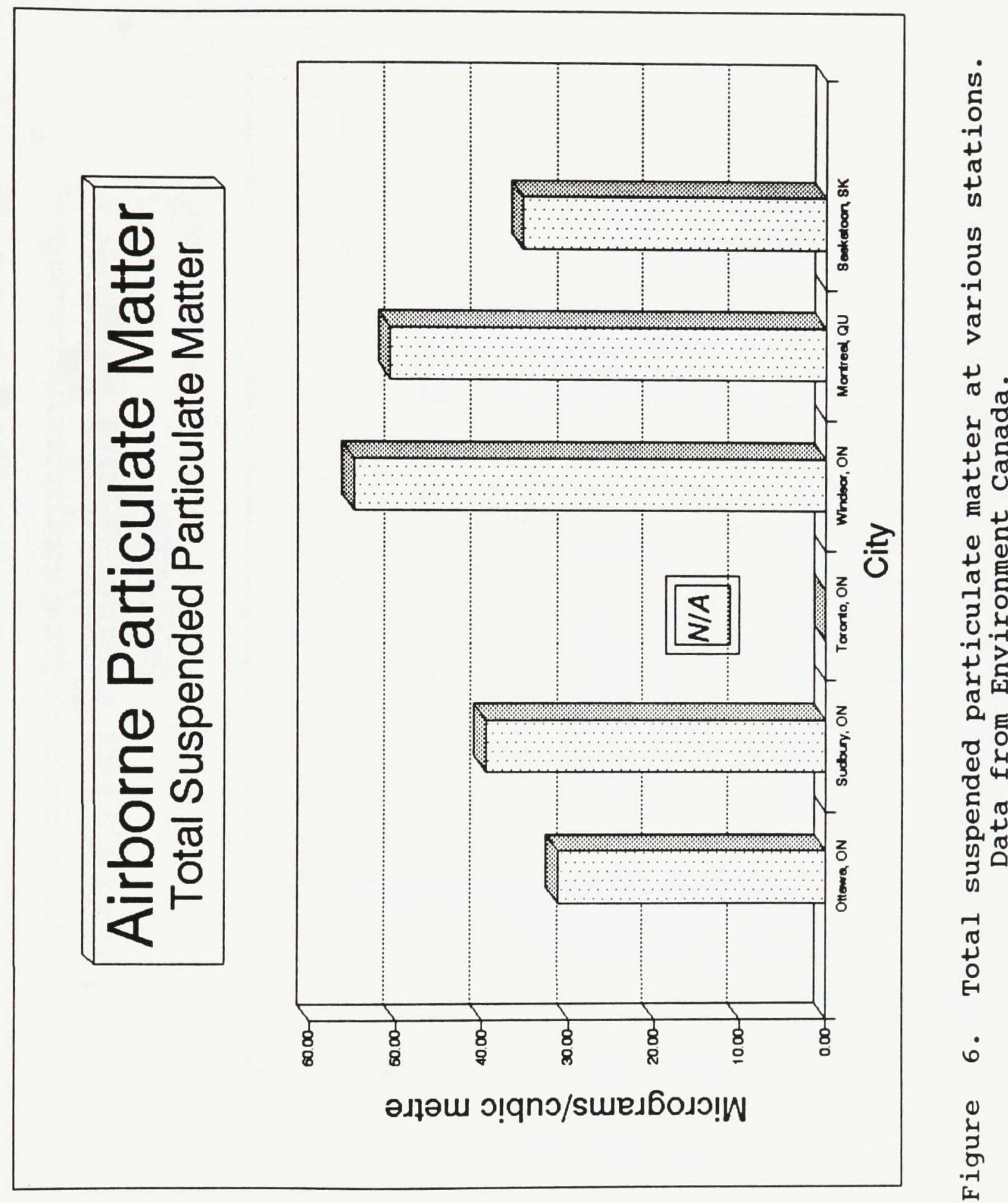


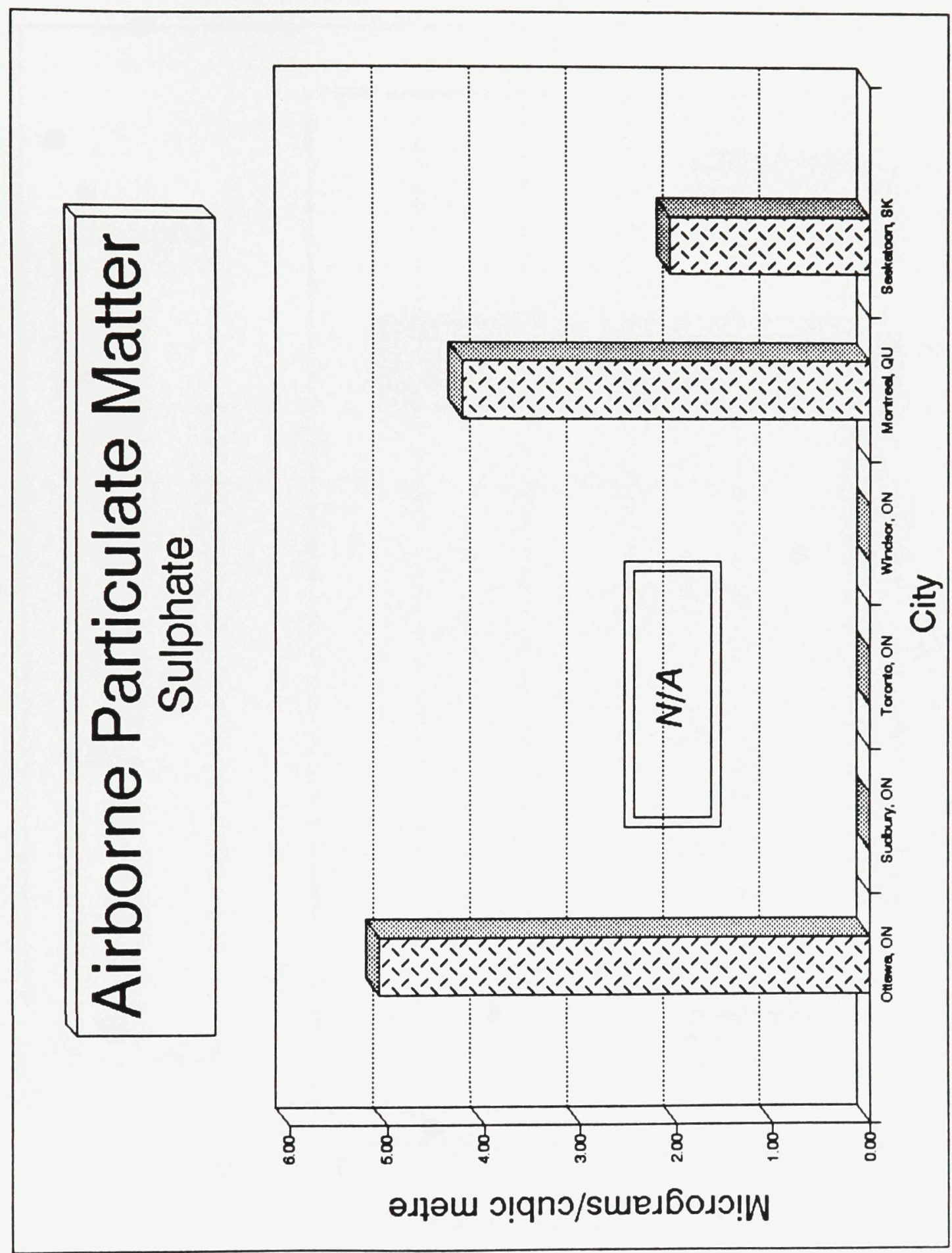

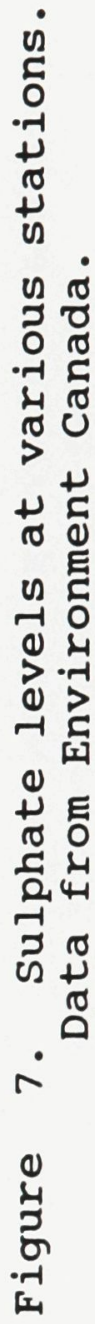




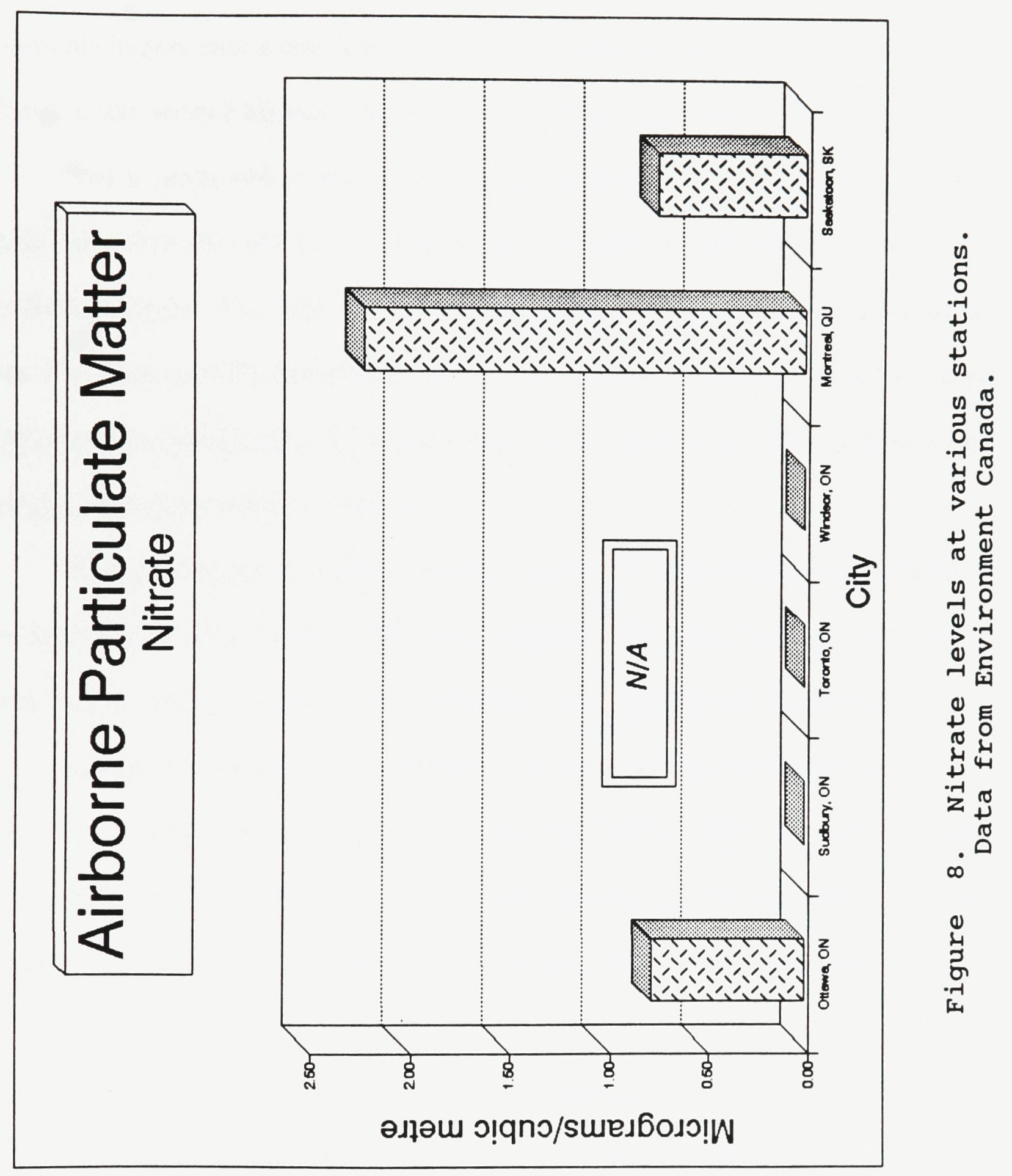


Toronto, Windsor or Montreal.

Ozone, $\mathrm{O}_{3}$, is a by-product of automobile and industrial combustion and commonly lingers over a city. The levels of ozone are similar for all areas measured. Ottawa ranks second highest, with an average 1991 level of $0.02 \mathrm{ppm}$.

Soot is measured in two different ways. The first is called the Soiling Index which measures the amount of reflectance (or lack of reflectance) of airborne particulate matter. The units are $\mathrm{COH}$ (coefficient of Haze) units per 1000 linear feet. The main particle detected is carbon. The second way soot is measured is as total suspended particulate matter in micrograms per cubic metre. This measurement includes all larger particles in the air.

Ottawa ranks moderately for soiling, much lower than Sudbury and Windsor, but much higher than Toronto. However, Ottawa ranks lowest for total suspended particulates, nearly half the level of Windsor (Toronto data not available).

Finally, the particulates sulphate and nitrate were measured in micrograms per cubic metre. Although amounts were reported for Ottawa, data were not available for Sudbury, Windsor, and Toronto. Sulphate was high in Ottawa relative to both Montreal and Saskatoon, but nitrate was very low compared to Montreal and about the same for Saskatoon.

The acidity of rainfall for Ottawa was approximated using data from three stations monitored by Environment Canada and the Ontario Ministry of Environment and Energy. The three sites are:

Dorset - $200 \mathrm{~km} \mathrm{SW} \mathrm{of} \mathrm{Ottawa}$ 


\section{Chalk River - 200 km NW of Ottawa}

Sutton - $200 \mathrm{~km} \mathrm{E}$ of Ottawa

Using the values from Table 2 , the average $\mathrm{pH}$ of rainfall at Ottawa is approximately 4.2 (unweighted average). Environmental damage to sensitive lakes is apparent below a pH of 4.7 and considered serious at pH 4.0 (Climatic Perspectives, Aug. 23-29, 1993).

Many of the pollutants discussed earlier act directly or indirectly to accelerate the weathering of stone. These pollutants can act to dissolve minerals or discolour the stone face.

$\mathrm{SO}_{2}$ oxidizes to sulphate which then reacts with water to form sulphuric acid. $\mathrm{NO}_{2}$ also reacts with oxygen to form nitrate, which then reacts with water to form nitric acid. $\mathrm{CO}$ reacts with water to form carbonic acid. All three acids dissolve minerals. Ozone is a measure of the added oxidation potential of the environment: the more ozone in a given environment, the faster $\mathrm{SO}_{2}$ and $\mathrm{NO}_{2}$ can be oxidized and become acids. The soiling index and total suspended particulate measurement indicate the amount of soot in the air which can accumulate on rock and blacken surfaces.

The $\mathrm{pH}$ of acid rain provides a measure of the potential for rainwater to deface carbonate surfaces and accelerate the corrosion of silicate rocks. The greatest effect on carbonate should be either on the west or east sides of buildings (since the prevailing winds are from the west, moisture generally is directed onto west-facing 
sides; since many of the storms come from the east, rain may be driven onto eastfacing sides). The south should show the least weathering due to prolonged exposure to sunshine. 


\begin{tabular}{|l|c|c|c|}
\hline \multicolumn{4}{|c|}{ ACID RAINFALL } \\
\hline Site & Date & $\mathrm{pH}$ & Rainfall \\
& & & \\
\hline Dorset & 23 & 3.7 & $2 \mathrm{~mm}$ \\
& 24 & 4.3 & $4 \mathrm{~mm}$ \\
& 26 & 4.2 & $1 \mathrm{~mm}$ \\
& 27 & 4.6 & $10 \mathrm{~mm}$ \\
Chalk River & 23 & 3.9 & $17 \mathrm{~mm}$ \\
& 24 & 4.2 & $5 \mathrm{~mm}$ \\
& 27 & 4.4 & $9 \mathrm{~mm}$ \\
& & & \\
Sutton & 24 & 3.8 & $50 \mathrm{~mm}$ \\
& 27 & 4.5 & $10 \mathrm{~mm}$ \\
\hline
\end{tabular}

Table 2. Acidity of rainfall during August 22-28, 1993. From : Climatic Perspectives, August 23-29, 1993 


\section{Chapter 4. Building Stone}

\subsection{History of building stone in Ottawa.}

The first stone type used for buildings in Ottawa was local limestone, probably removed from the Rideau Canal or along the Ottawa River. The oldest stone building in Ottawa is the Bytown Museum (formerly the Commissariat Building) which was built in 1827 from blocks of local limestone and some igneous and metamorphic fieldstone. The oldest part of town is the Byward market area, where most buildings were built with locally quarried limestone. Some of the more notable local limestone buildings in this area are: the Geological Museum at 541 Sussex Street (1880), the Clarendon Hotel at 543 Sussex Street (1865), the Valade House at 142 St. Patrick (1865), the Donnelly House at 365 Sussex (1844, restored in 1974); the Daly Building, built in 1904-5, was possibly the last large structure built with local limestone. The Chateau Laurier (1908-12) utilized Indiana Limestone, as did the Government Conference Centre (1912). The Lorne building facade on Elgin Street is made of Deschambault limestone from Quebec. Acquiring replacement and renovation records for some of these buildings is difficult.

Although locally derived limestone continued to be used for smaller structures, Nepean sandstone became a more common building stone toward the latter part of the 1800s. Nepean sandstone was quarried just north of Timm Road and east of Eagleson Road in Bells Corners. The quarry is at most $9 \mathrm{~m}$ deep, and covers an area of almost $3,000 \mathrm{~m}^{2}$. Some of the more prestigious houses used Nepean sandstone, 
and this stone became a significant component in government buildings such as: Parliament (1860-1867, Centre Block 1917-1927); the War Museum at 300 Sussex Street (1904-08); Victoria Museum at Metcalf and McLeod Streets (1905-12); Lisgar Collegiate (1874, rebuilt 1893); the Connaught building on Sussex Street (1913-14); the Royal Canadian Mint at 320 Sussex Street (1905-08); and the Confederation Building on Wellington and Bank Streets (1927-31). Walls of some of these buildings are primarily Nepean sandstone, and others are a mixture of Nepean sandstone, Wallace sandstone, Ohio sandstone, Potsdam sandstone and other types of stone. The Langevin Block, at Wellington and Elgin Streets, was built in 1883-1889 with sandstone from New Brunswick. The sandstone is bimodal, very coarse grained (up to $1 \mathrm{~cm}$ wide clasts), and brown in colour. Although no specimens of the rock could be collected, spalling and pitting is evident in the large lower-level blocks.

The most common types of non-local building stone used in the late 1800's or early 1900's were: Wallace sandstone, Ohio sandstone, Potsdam sandstone, Tyndall limestone, Deschambeault limestone, Indiana limestone, Hampstead granite, and, Stanstead granite (Quebec). Local limestone continued to be an important component only in foundations. Nepean sandstone is decorative, but not particularly uniform. Wallace sandstone is a very consistent stone available in considerable quantity. Ohio sandstone is also uniform, abundant, and soft, making it easy to fashion into large, variously shaped blocks. Tyndall limestone is soft, coarsely fossiliferous and distinctively coloured, which makes it an attractive polished interior stone. Indiana limestone is soft and easily carved into figures. 
Most buildings constructed in the 1900 s opted for brick or other materials. In the past thirty years, however, building stone has reappeared, mainly for use as facades. These facades have been made of granite, anorthosite, limestone, and many other rock types. For the most part, it is too early to evaluate the durability of these facades.

\section{$\underline{4.2 \text { Stone types and specifications }}$}

For this thesis, 16 samples of building stone were gathered: nine types of stone from buildings in Ottawa, and seven types from a supplier of tile and building stone. These samples were labelled 1 through 16 and from these, eight sub-samples for each were cut and labelled A through $\mathrm{H}$.

Some samples were large enough to cut American Standard and Testing Methods (ASTM) regulation sized sub-samples (minimum 2" faces, maximum 3" faces); however, most samples were too small, and only chip sub-samples (2" x 1" x 0.25 ") could be used. Table 3 defines the samples and their sources, if known. For X-ray diffraction identification, refer to Appendix I, and for thin section examination, refer to Plates $1-8$.

Number 1 is Nepean sandstone. This sample, derived from the Parliament buildings and supplied by the stone mason from Public Works, was a rectangular core building block from Centre Block. Sub-samples cut from this block were big enough to comply with the ASTM regulations, and so for many tests, ASTM size restrictions were followed. 
Nepean sandstone is a relatively pure quartz arenite which varies in porosity and type of cement depending on the stratigraphic horizon. Quartz cement is the most common, but layers and lenses containing calcite cement are abundant. Much of the Nepean sandstone is bimodal, and both sphericity and roundness are well to moderately well developed.

Bedding and cross-bedding are apparent both in-situ and in building blocks, and slight waning-current grading is common. Fractures were not seen in thin section either between the grains or within the grains. Although rarely seen in thin section or detected in X-ray diffraction patterns, pyrite is common in some building blocks.

Number $\mathbf{2}$ is Wallace sandstone from Wallace, Nova Scotia. A large block was acquired which had been a sill for a window on the Peace Tower of the Parliament buildings. ASTM regulation size blocks and additional chips were cut from this sample.

The rock is greenish brown, lightly speckled, and vaguely bedded. The grain size is unimodal. The average modal composition is $80 \%$ quartz, $20 \%$ plagioclase feldspar, and some clay minerals and mica. Both bedding and cross bedding are commonly accentuated by faint alignments of opaque minerals (Plate 1B). Grains are semi-angular to rounded, unoriented, and closely packed. Most of the quartz grains have a faint colour, and although pervasive fractures are rare, micro-fractures within some of the grains are common.

Number 3 is Ohio sandstone from Ohio, U.S.A. This sample, an ornamental cap for a stairway rail leading into the Centre Block of the Parliament buildings, was 


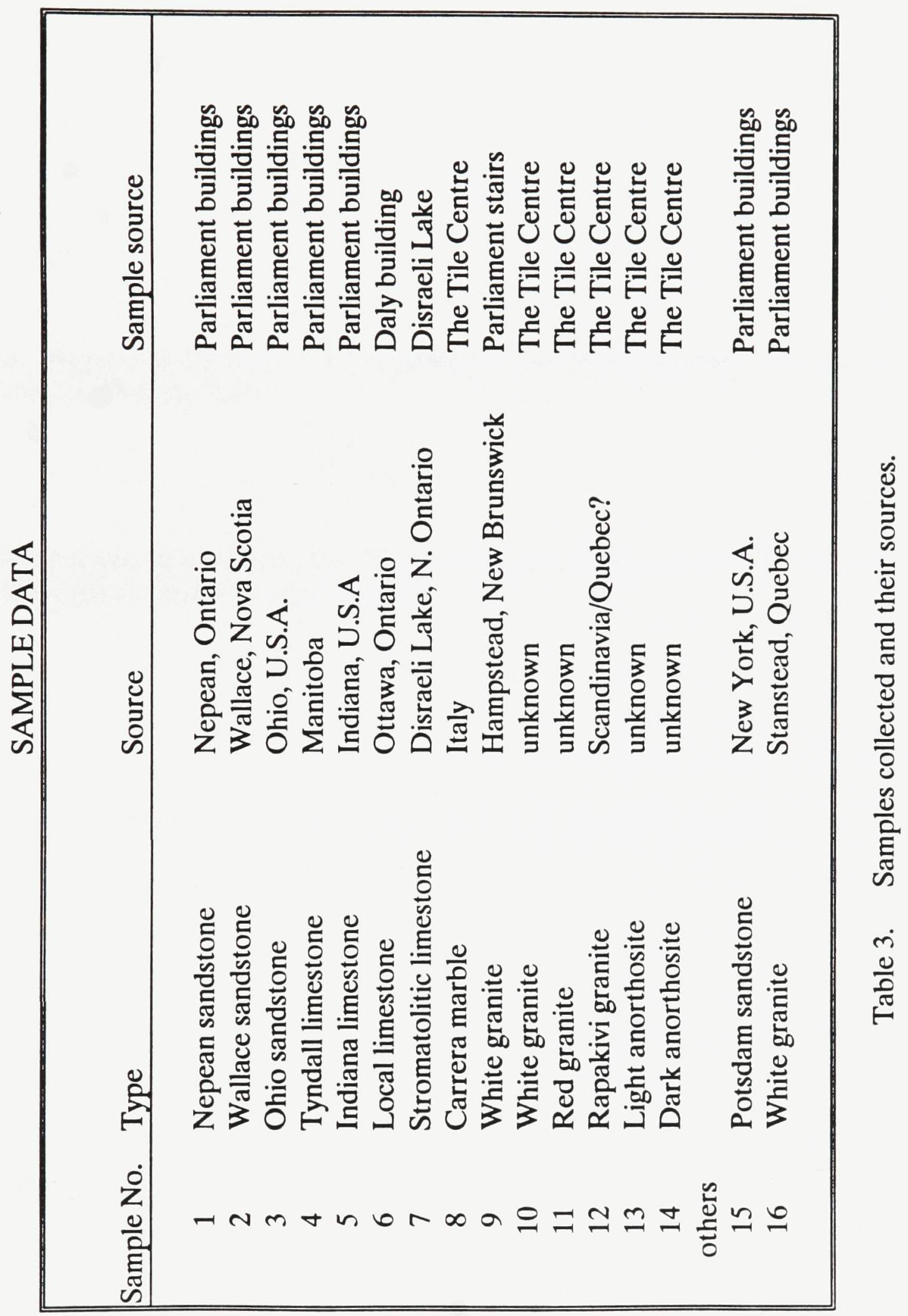




\section{Plate 1.}

A. Nepean sandstone: $2.5 \mathrm{X}$, crossed polars. Well rounded, bimodal quartz grains, well packed together.

B. Wallace sandstone: $2.5 \mathrm{X}$. Note the slightly pinkish-brown colour imparted by the lithic grains and silty matrix (A).

** Note: $2.5 \mathrm{X}$ is the magnification of the ocular lense. 

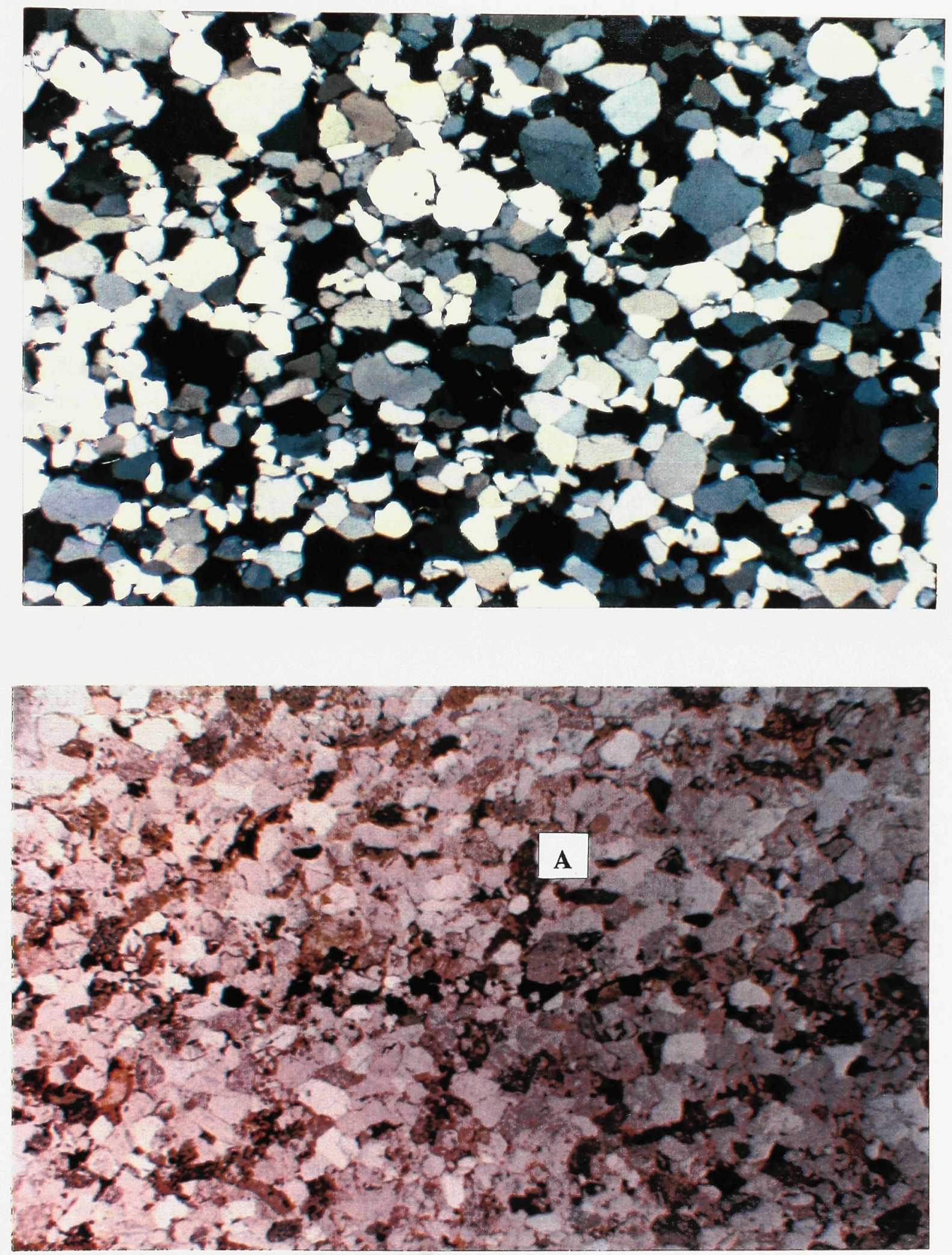


\section{Plate 2.}

A. Ohio sandstone: $2.5 \mathrm{X}$. Central clay-rich layer separates fine grained beds of angular lithic and quartz sand grains. Darker brown material is clay and iron oxide staining.

B. Indiana Limestone: $2.5 \mathrm{X}$. This is an assemblage of ooids and fossil fragments showing only faint alignment parallel to bedding (close to long dimension of photograph). 

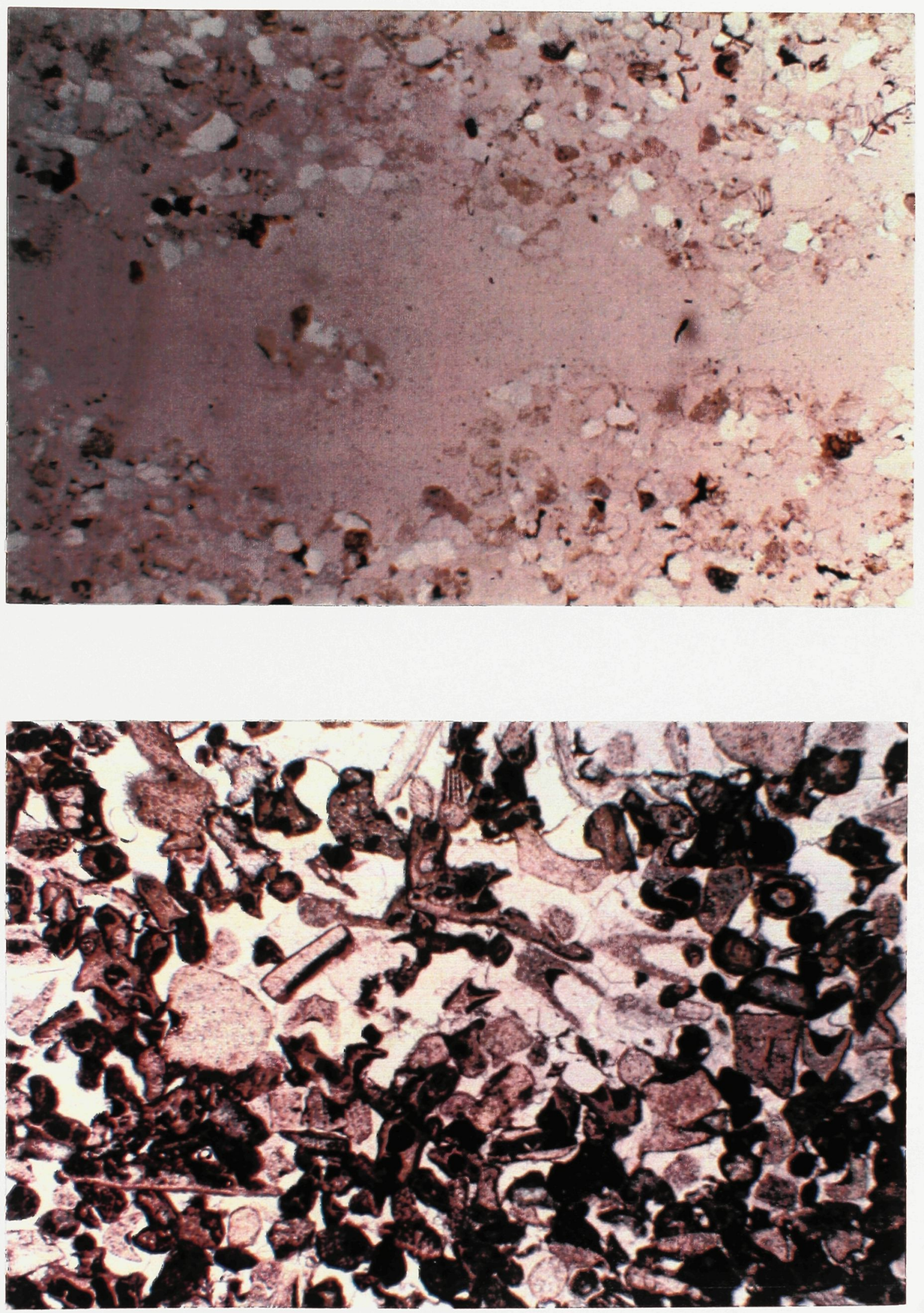
Plate 3.

A. Tyndall limestone: $2.5 \mathrm{X}$. Slight variations in colour denote bedding.

B. Cobourg limestone: $2.5 \mathrm{X}$. The matrix is dominantly small ooids which suspend fossil fragments. 

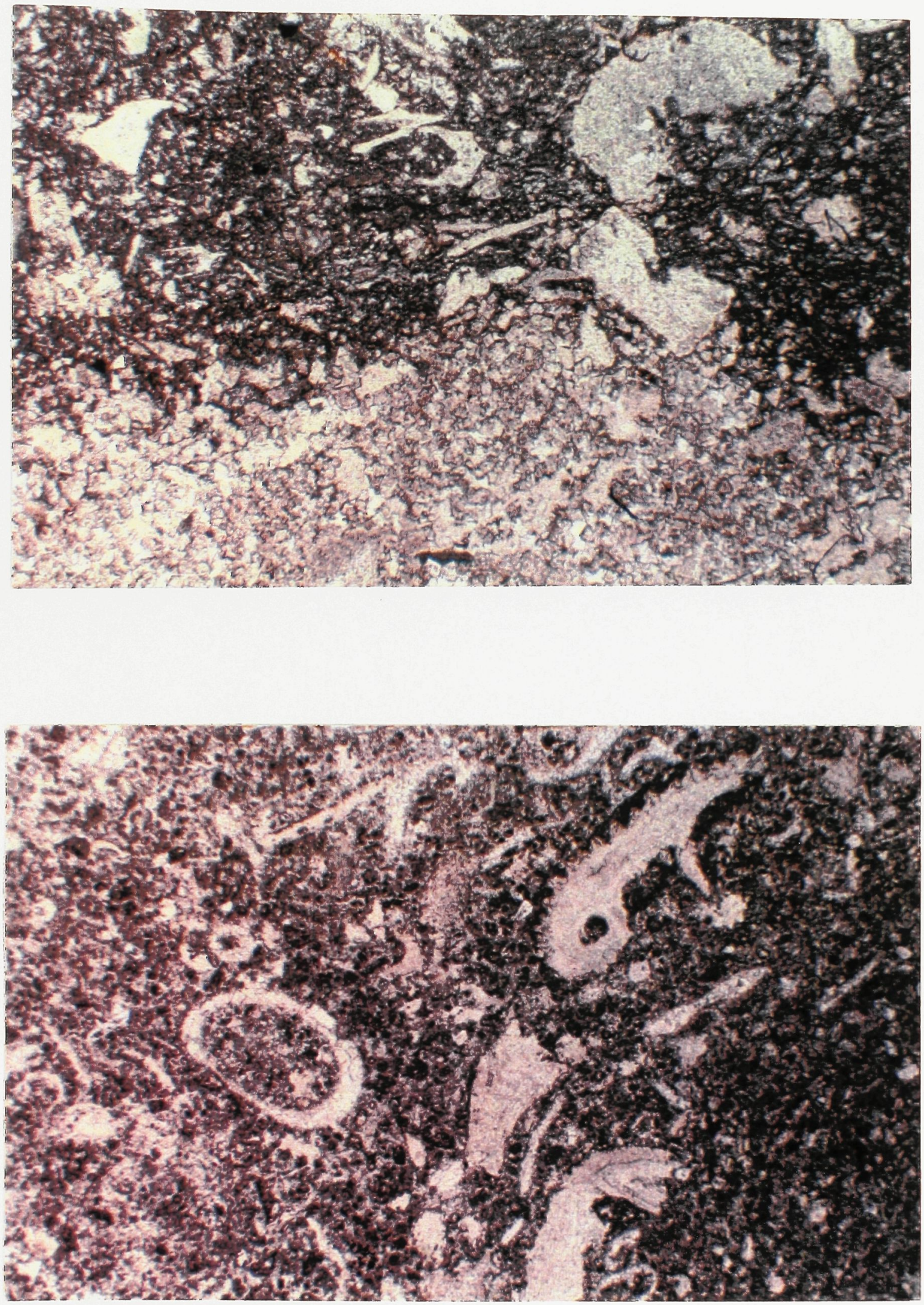
Plate 4.

A. Cobourg limestone: $2.5 \mathrm{X}$. This plate shows a portion of a jagged, clay-lined stylolite (A).

B. Cobourg limestone: 2.5X. Penetrative fractures (A) are abundant. 

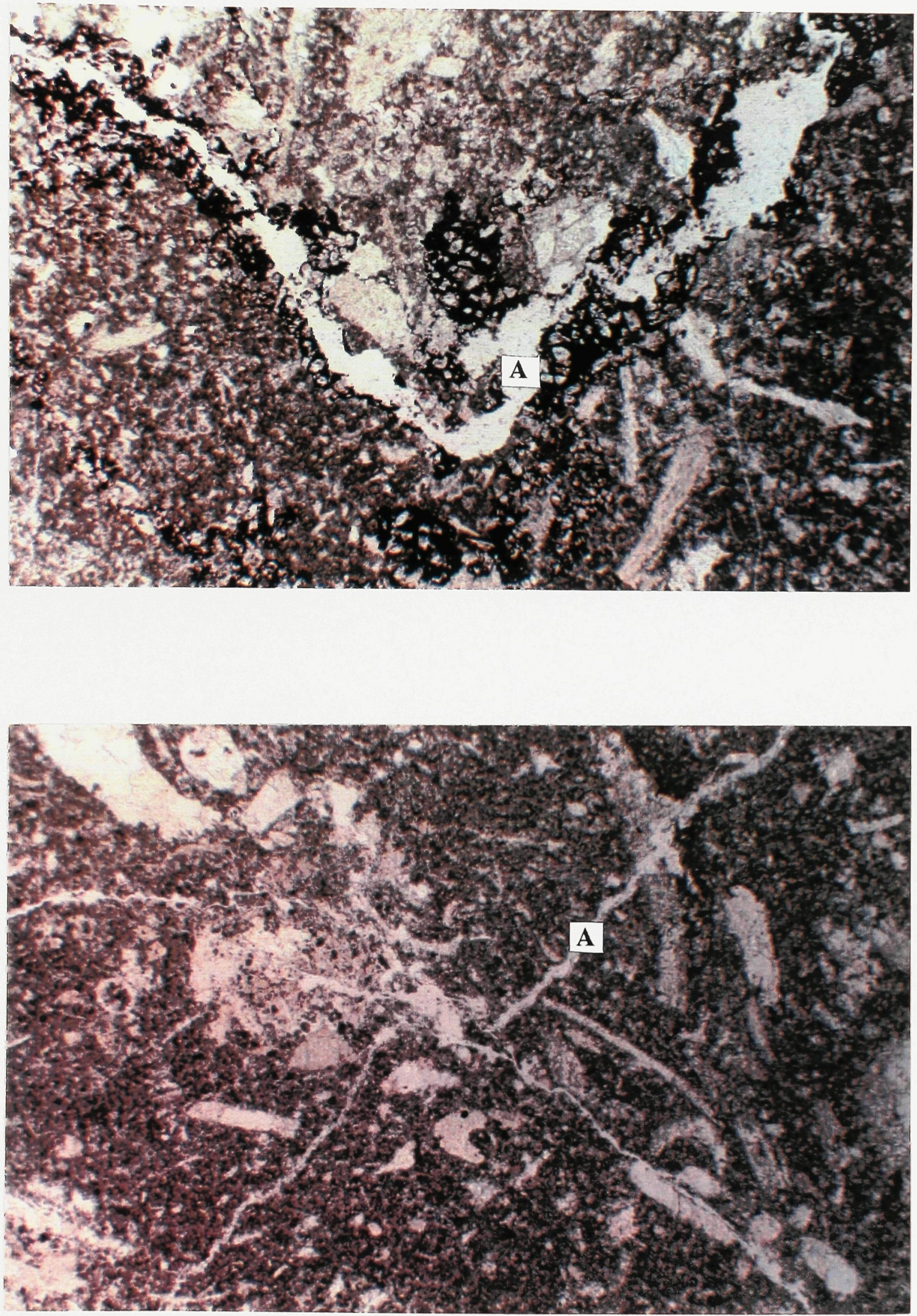
Plate 5.

A. Disraeli Stromatolite: 2.5X. Large crystals of dolomite (A) fill layers, cavities and fractures.

B. Carera Marble: $2.5 X$. Equant calcite crystals form a compact isotropic fabric. 

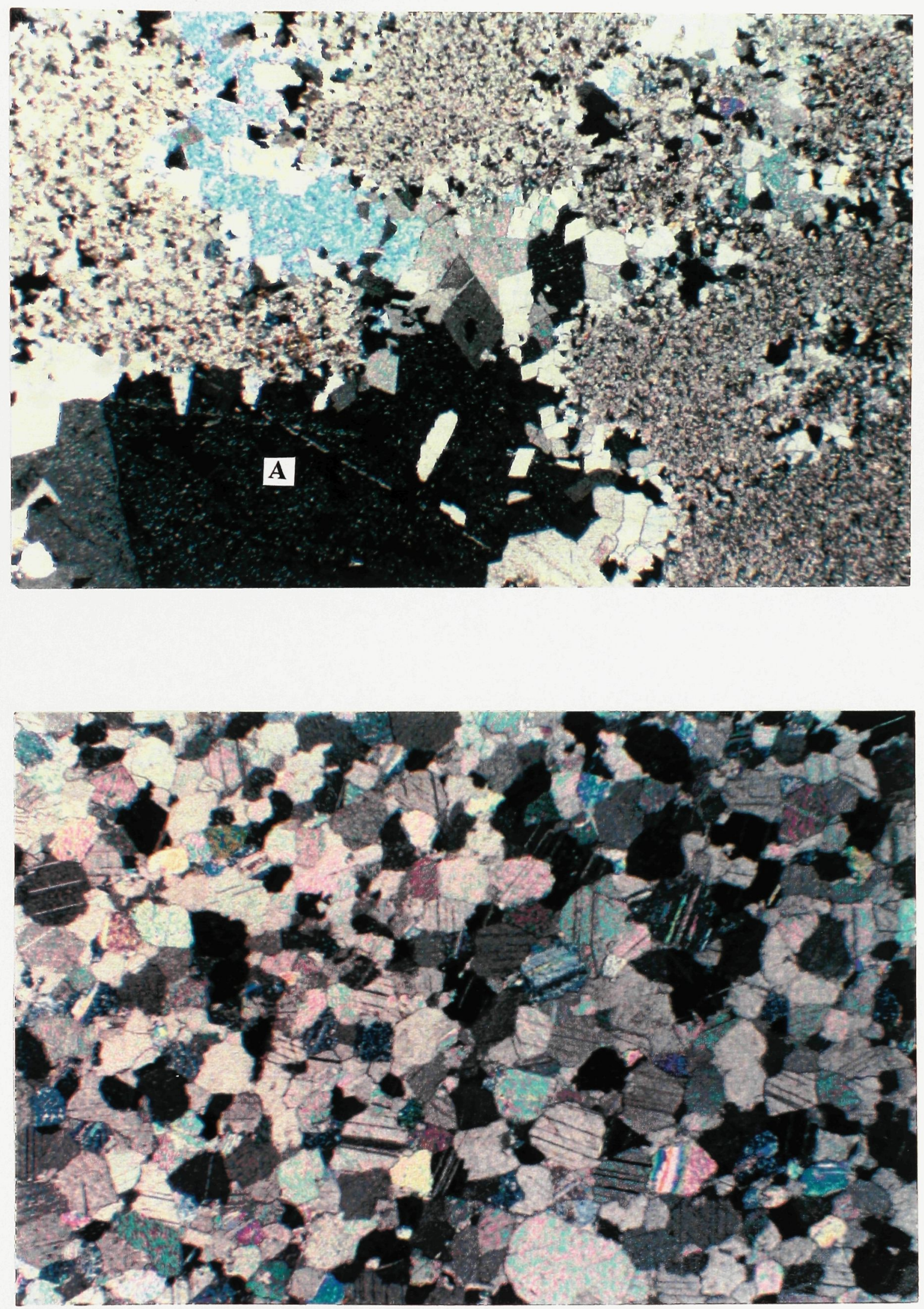
Plate 6.

A. Hampstead granite: 2.5X. Composed of quartz (Q), plagioclase feldspar (F) and biotite (B). A few small crystals of zircon are scattered in the section $(Z)$.

B. White granite: $2.5 \mathrm{X}$. Similar to Hampstead granite, with mainly plagioclase (F), quartz and biotite (B). 

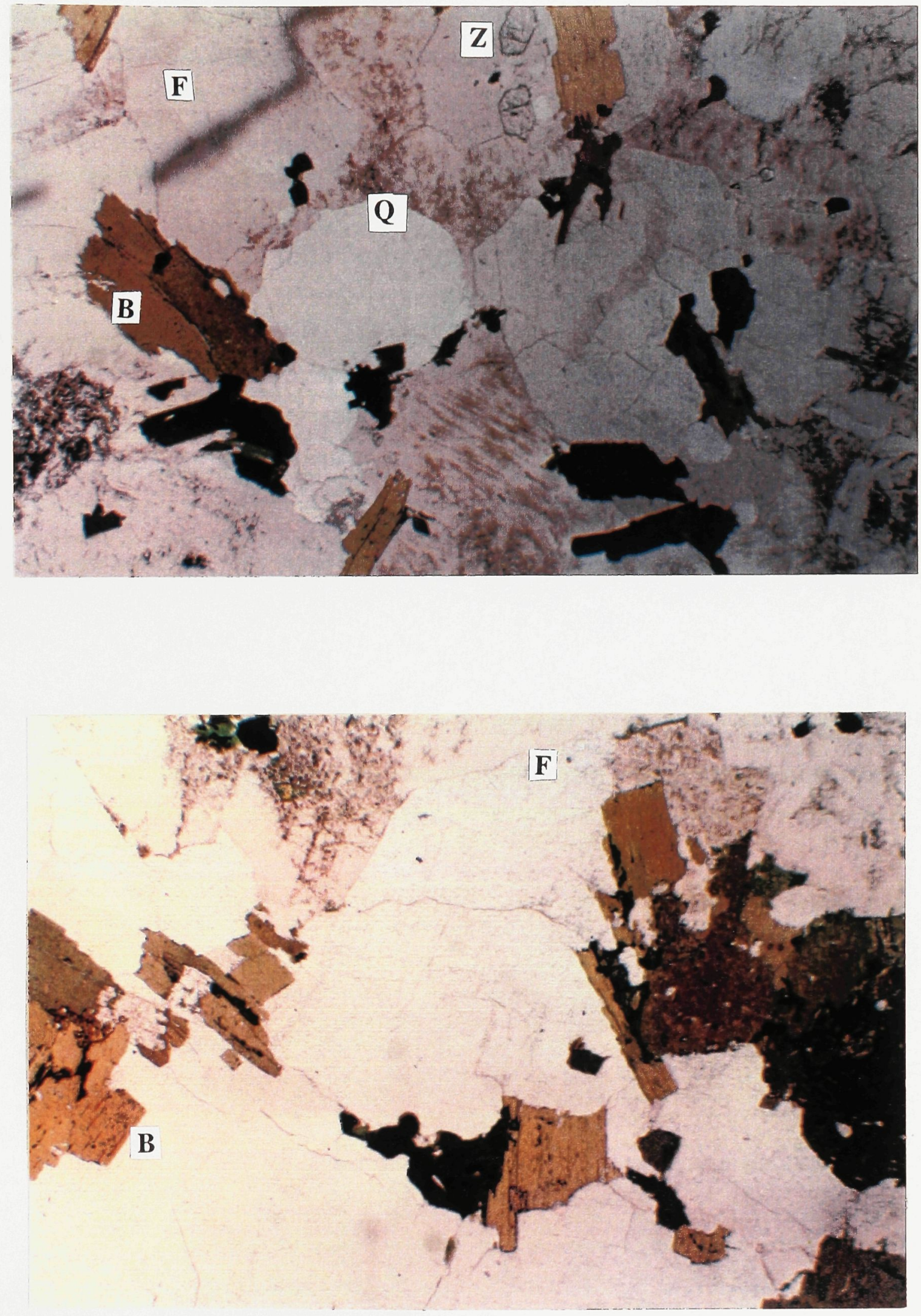
Plate 7.

A. Red granite: $2.5 \mathrm{X}$, crossed polars. This rock is characterized by large, euhedral crystals of plagioclase feldspar $(F)$, interspersed with less quartz, magnetite, and mica.

B. Rapakivi granite: 2.5X. Round euhedral crystals of potassic feldspar ( $\mathrm{Pf})$ are surrounded by plagioclase feldspar (F). Magnetite can also be seen (M). 

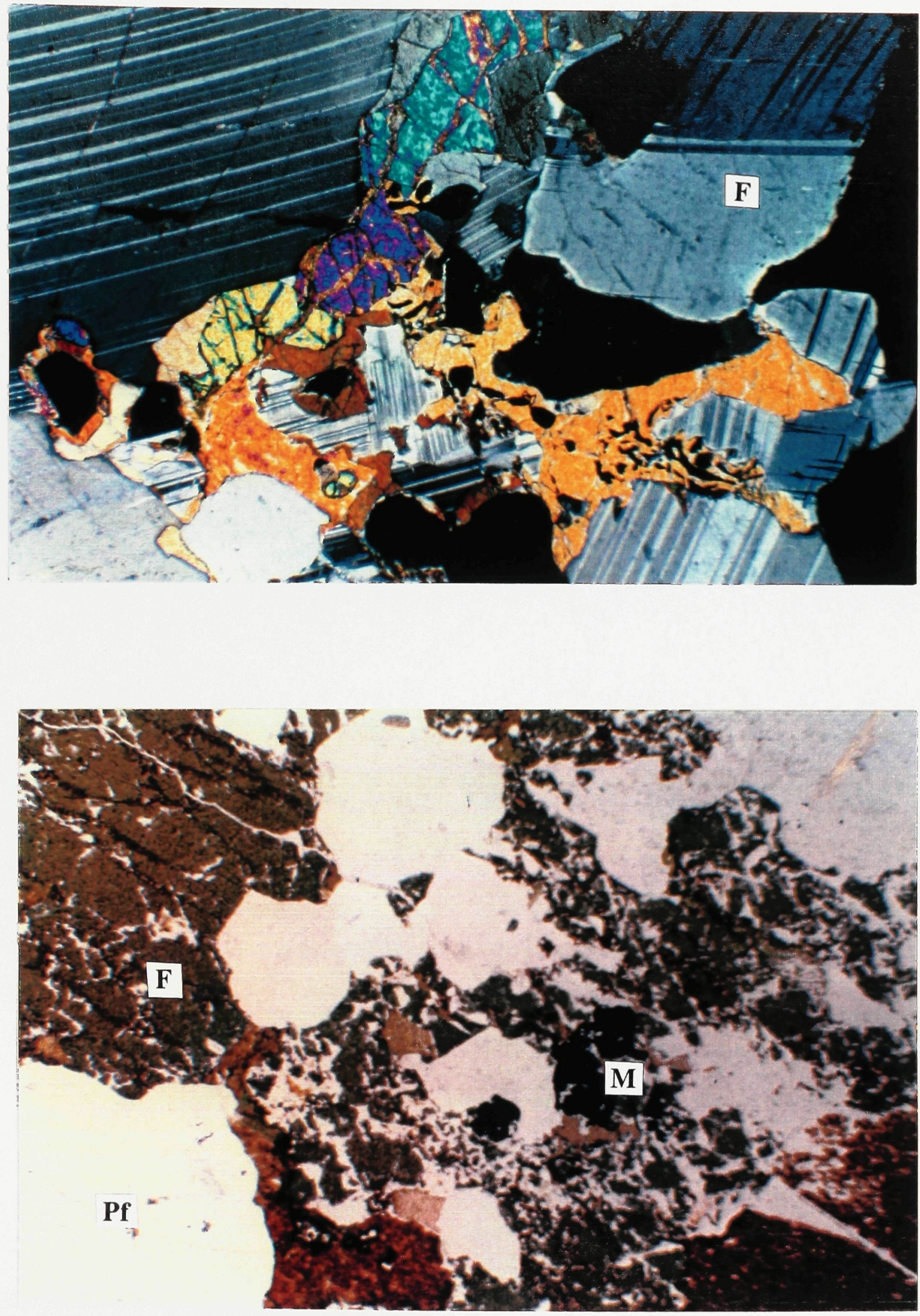


\section{Plate 8.}

A. Light anorthosite: $2.5 \mathrm{X}$. Mostly calcic plagioclase feldspar (F) with significant amounts of biotite altering to magnetite (B-M).

B. Dark anorthosite: 2.5X. Similar to the light anorthosite. Apatite crystals (A). 

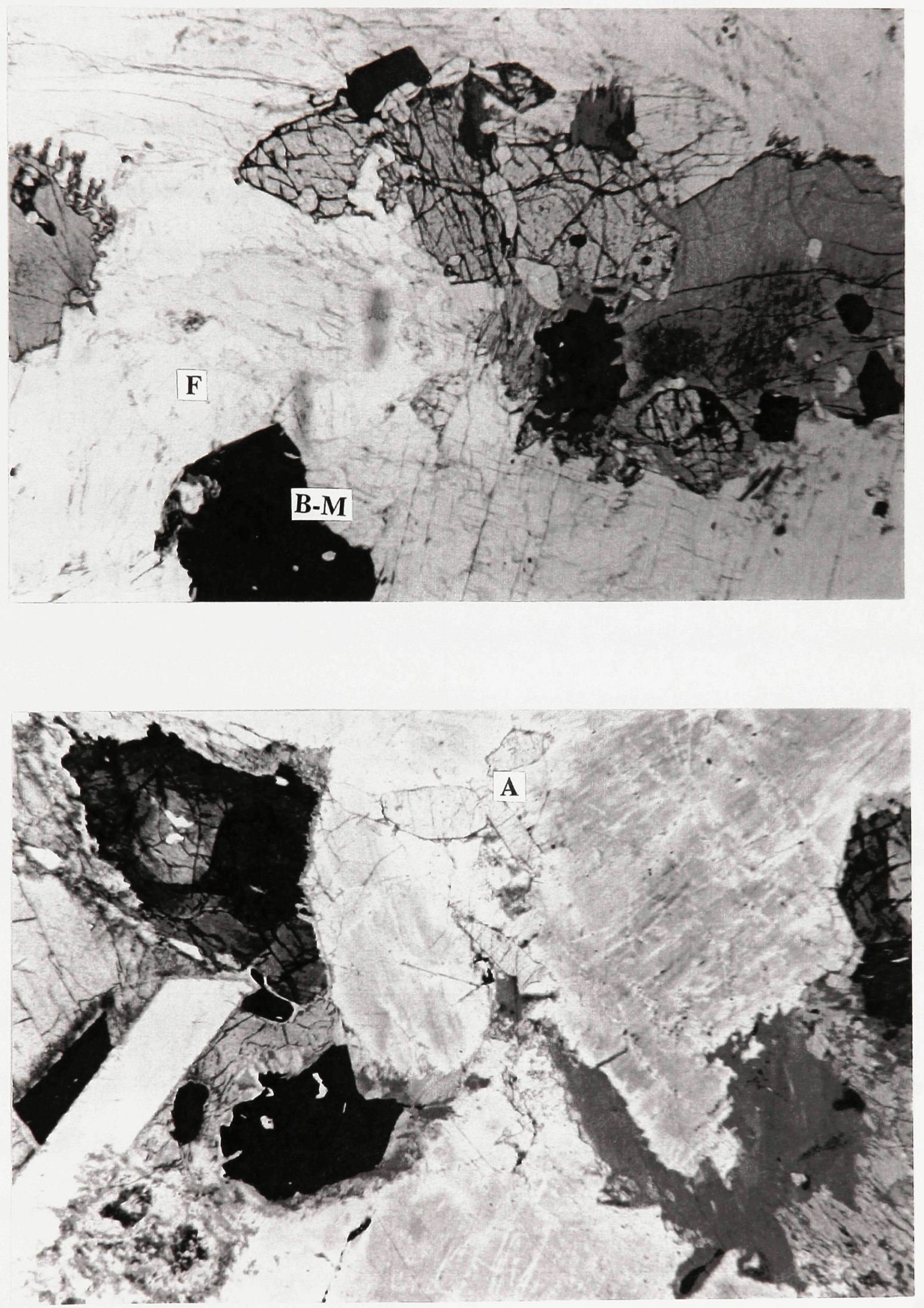
large enough to cut ASTM regulation- size sub-samples. Except in the Peace Tower, Ohio sandstone makes-up the coping stone, cornices, and window dressing stone for the Parliament buildings.

Ohio sandstone consists dominantly of framework quartz, with a significant clay mineral component and minor mica, which accounts for the softness and suitability for the carving of irregular-shaped blocks. No fractures or seams were seen in thin section, but fine matrix marks beds and other structures. Minute spots of ironoxide are ubiquitous.

Number $\mathbf{4}$ is Indiana Limestone from Indiana, U.S.A. The sample came from a fresh block intended for use in carvings on the exterior of the Parliament buildings. This limestone is light buff coloured, medium to coarse grained, and very fossiliferous. In thin section, clear fossil fragments, oolites and grains are interspersed with crystals of calcite cement. The mineralogy is nearly pure calcite, with a very minor quartz component. The main use for this limestone at Parliament is ornamental figures and some stair rails, but it is a significant building stone in many U.S. and Canadian buildings. No fractures or structures were observed.

Number $\mathbf{5}$ is Tyndall limestone from Manitoba. This sample was used for the interior of the Centre Block of Parliament. The rock is a rich buff-brown colour, fine to coarse grained, and contains abundant fossils and trace fossils that commonly exceed $5 \mathrm{~cm}$ in length. The mineralogy consists primarily of calcite and dolomite, with minor quartz. Bedding is marked by slightly different shades of carbonate.

Number $\mathbf{6}$ is local limestone taken from the Daly building after demolition. 
The origin of the limestone is considered to be from the Coburg Formation quarried near the building site. The rock is a bluish-grey colour and fine to coarse grained. Vugs are common and contain crystals of calcite as linings or infills.

The mineralogy is dominantly calcite with a trace of quartz. Unlike most of the other building blocks, this rock contains abundant pervasive and interconnected fractures and stylolites. The bulk of the rock is a muddy fine matrix of calcite accommodating a myriad of fossils, fossil fragments, and oolites. The oolites tend to be concentrated in particular beds. Fractures are common and range from fine to wide. Many of the fractures are open, but some follow clay-lined stylolites. The stylolites are usually jagged and irregular, and most can be traced throughout the width of individual building stones. The open gap in the centre of the stylolite shown in Plate $4 \mathrm{~A}$ is possibly due to frost or salt wedging.

Number $\mathbf{7}$ is a stromatolitic marble from Disraeli Lake near Thunder Bay, Ontario. This material was sampled and examined due to the exotic appearance and interest for development. Samples collected came from the surface and no sound, completely unweathered rock could be collected.

The rock is variably coloured with hues of red and purple. The mineralogy is dominated by dolomite, with lesser amounts of calcite, quartz, and chlorite. the sample is generally laminated or banded in concentric patterns, and some fractures follow these bands where the rock had been weathered. Thin sections show the finely crystalline nature of the bulk of the rock. Large pores and fractures are commonly infilled with large interlocking crystals of calcite or dolomite. Some fractures are 
open, with calcite crystals lining the walls, as in Plate 3B.

Number 8 is Carera Marble from Italy. The sample was provided by The Tile Centre on Carling Avenue in Ottawa. This is a white, massive, medium-grained, marble dominated by calcite, with minor amounts of dolomite and quartz. The grain size is fairly uniform, and neither porosity nor structural deformation is apparent.

Number 9 is a white granite from Hampstead, New Brunswick, which has been used for sidewalks, stairs, and monument bases. Because this particular sample came from the base of a monument, ASTM sized blocks could be cut.

The principal minerals are feldspar, quartz, and mica. The texture is coarse grained and equigranular. In hand sample, large but sparse crystals and masses of pyrite are common. In thin section, the crystals appear tightly bound and euhedral. A few apatite crystals less than $0.01 \mathrm{~mm}$ in diameter display basal fractures. There is little evidence of alteration. No pervasive fractures were observed in the rock.

Numbers $10-14$ are from The Tile Centre, and their origin is unknown. Number 10 is a white granite composed of feldspar, mica, and quartz. Some of the biotite has been corroded, and rare micro-fractures were seen in the quartz grains.

Number 11 is a red granite composed of feldspar, quartz and, mica. The thin section shows widespread replacement of biotite by magnetite. Plagioclase crystals are large laths which in places contain cross-cutting micro-fractures. Mica and magnetite are common at the junctions of large feldspar crystals.

Number 12 is a Rapakivi granite, possibly from Quebec. Large, ovoid orthoclase crystals are rimmed with greenish plagioclase. Magnetite is a common 
alteration of biotite and constitutes a up to $4 \%$ of the rock. A few fractures were seen in hand specimen and thin section, but are discontinuous and sealed.

Number 13 is a light coloured anorthosite with $1-2 \mathrm{~cm}$ lath-shaped anorthite intergowths and minor mica. The biotite is generally altered to magnetite.

Number 14 is a dark coloured anorthosite with coarse crystals of anorthite, amphibole, lesser mica, and magnetite.

Number 15 is a red sandstone from Malone, New York, that was used sparingly for arches in the Parliament Buildings. This sandstone consists mainly of quartz, with up to five percent white clay minerals. This sample was too small to carry out any tests or analysis.

\section{$\underline{4.3 \text { Analyses. }}$}

Analyses were performed on the samples to calculate the bulk specific gravity, the amount of water absorption over time, the variation in absorption, the porosity, and the distribution of pore sizes.

Bulk specific gravity and absorption were calculated following ASTM regulation C97-47 (1982). Bulk specific gravity is a means of determining the unit weight of the rock, and absorption is the amount of water absorbed by a rock over a 48 hour period.

Samples 1,2,3,6, and 9 were large enough to meet ASTM size restrictions, but all other samples were not. For this reason, the analyses were performed twice with two sets of sub-samples to gauge the accuracy and average the results. The accuracy 
for the large (ASTM) samples was very good, but less so for the small chip samples. A cross reference graph was produced to indicate the accuracy by superimposing the specific gravity results of the ASTM blocks over the averaged chip sub-sample results (Figure 11).

The specific gravity results are tabulated in Appendix 1, and are illustrated in Figures 9 and 10. Specific gravity was calculated in the following manner:

$$
\text { Bulk specific gravity }=\mathrm{A} /(\mathrm{B}-\mathrm{C})
$$

where:

$A=$ weight of the dried specimen

B = weight of the soaked and surface-dried specimen in air, and

$\mathrm{C}=$ weight of the soaked specimen in water.

The bulk specific gravity is the ratio of mass to that of an equal volume of water. When this density figure is multiplied by 62.4 , the unit weight per cubic foot (pounds/ $\mathrm{ft}^{3}$, the common measure for manufacturers) is generated. If the specific gravity is too high, above $140 \mathrm{lb} . / \mathrm{ft}^{3}$, the rock is considered too hard; if it is below $105 \mathrm{lbs} / \mathrm{ft}^{3}$, it is considered too weak (Moen, 1967).

The specific gravity of the sandstones and limestones of the Parliament and Victoria Museum buildings is generally low, indicative of low density minerals and open packing of the framework grains. The remainder of the samples are much higher in density.

The absorption results are tabulated in Appendix 1 and are illustrated in 
Figures 12- 14. Absorption was calculated over a 48 hour period and then for a 4 week and 6 week period. Samples were dried in an oven at $105^{\circ} \mathrm{C}$ for 48 hours, weighed, and then submerged in water at room temperature. After 48 hours, 4 weeks, and 6 weeks, the samples were weighed and the absorption calculated as:

$$
\text { Absorption, weight } \%=[(\mathrm{B}-\mathrm{A}) / \mathrm{A}] \times 100
$$

where:
$\mathrm{A}=$ weight of the dried specimen, and
B = weight of the specimen after immersion.

The percent absorption increased moderately from the 48 hour to the 6 week period. Samples $1-5$ are prone to absorb water relative to the remainder of the samples, which absorb very little water. Ohio sandstone absorbed the most water, reaching $11 \%$ over 6 weeks. This is a crude measure which is controlled partly by porosity and partly by permeability. Similar to density, high absorption (above 17\%) constitutes weakness, and low absorption (below 3\%) indicates excessive hardness (Moen, 1967).

Discrepancies between this absorption test and repeated tests could be accounted for by variations within the stone type. A simple test was applied in which a single drop of water placed on the surface of a sample was used to estimate the initial rate of absorption, and several drops over the face of a sample were used to determine the variability in absorption rate for each rock. This test will be termed 

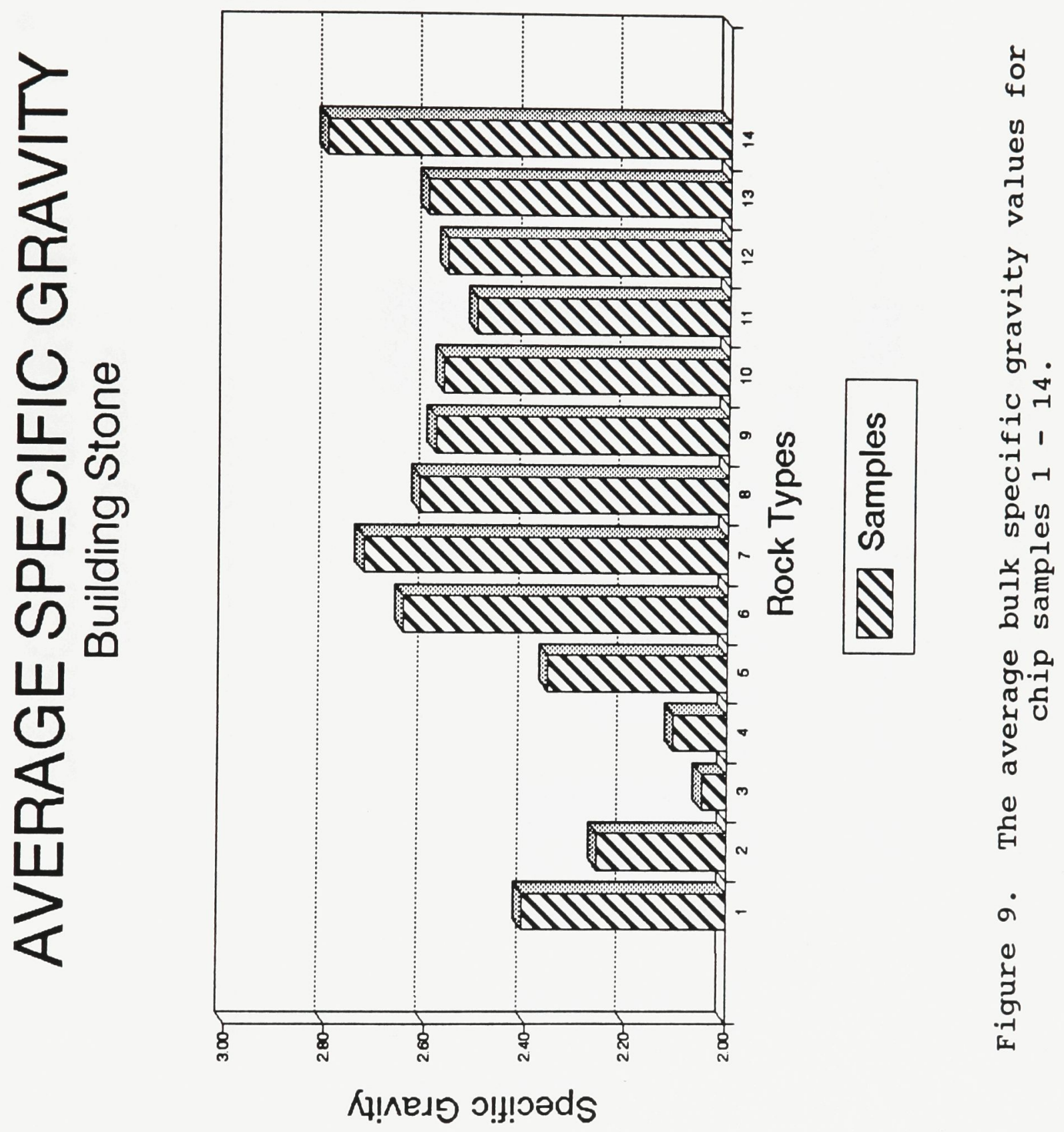

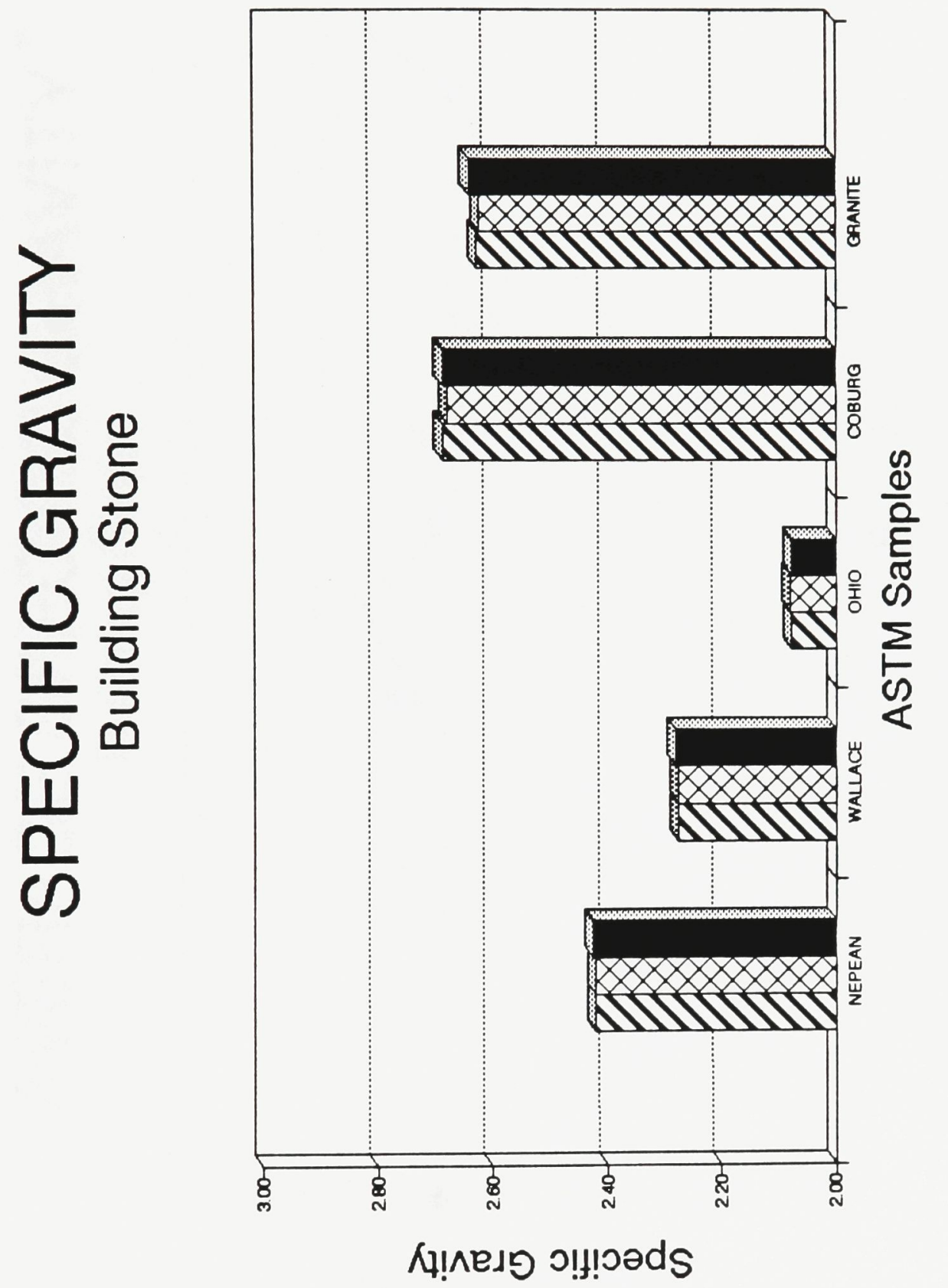

年 


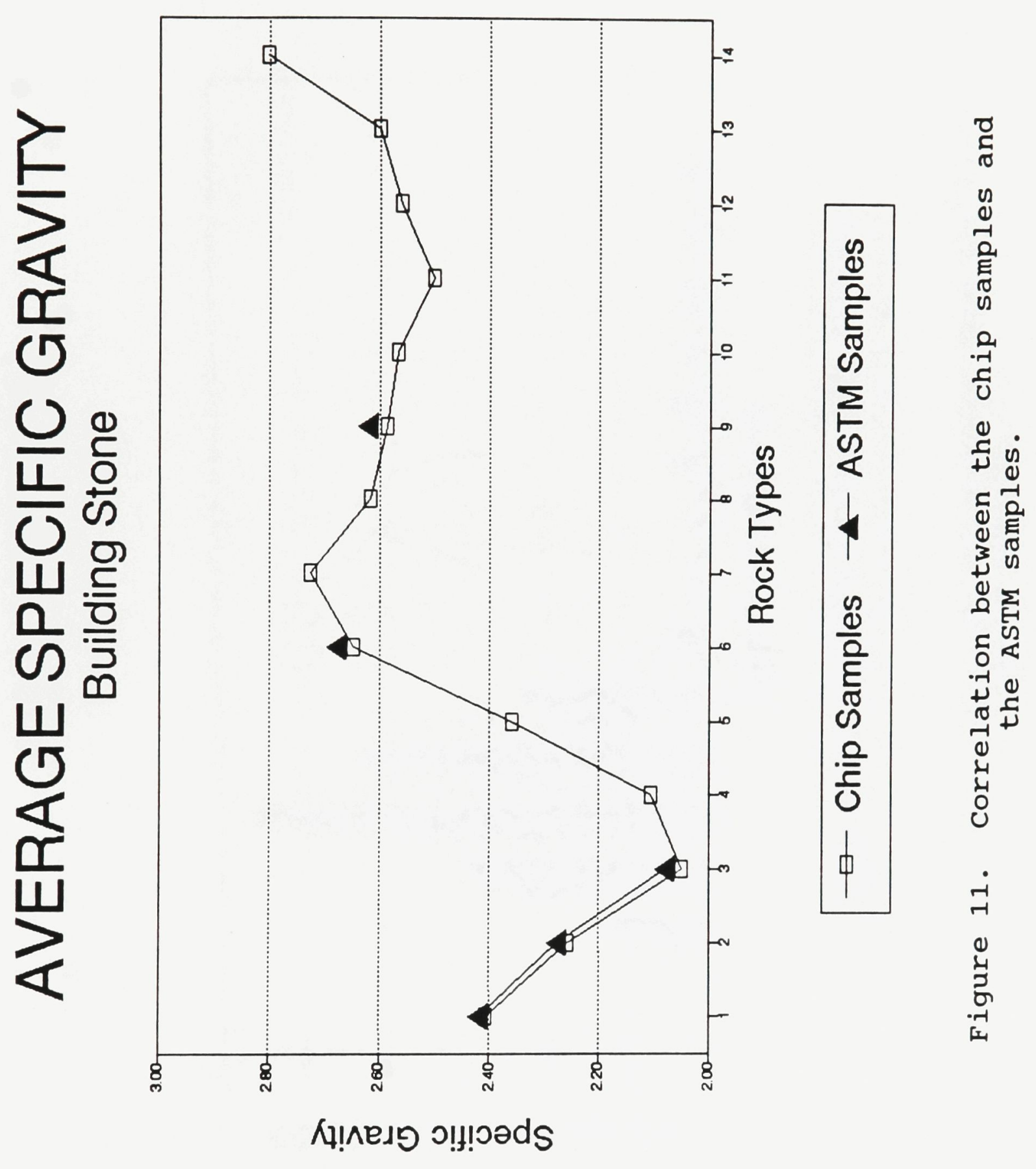




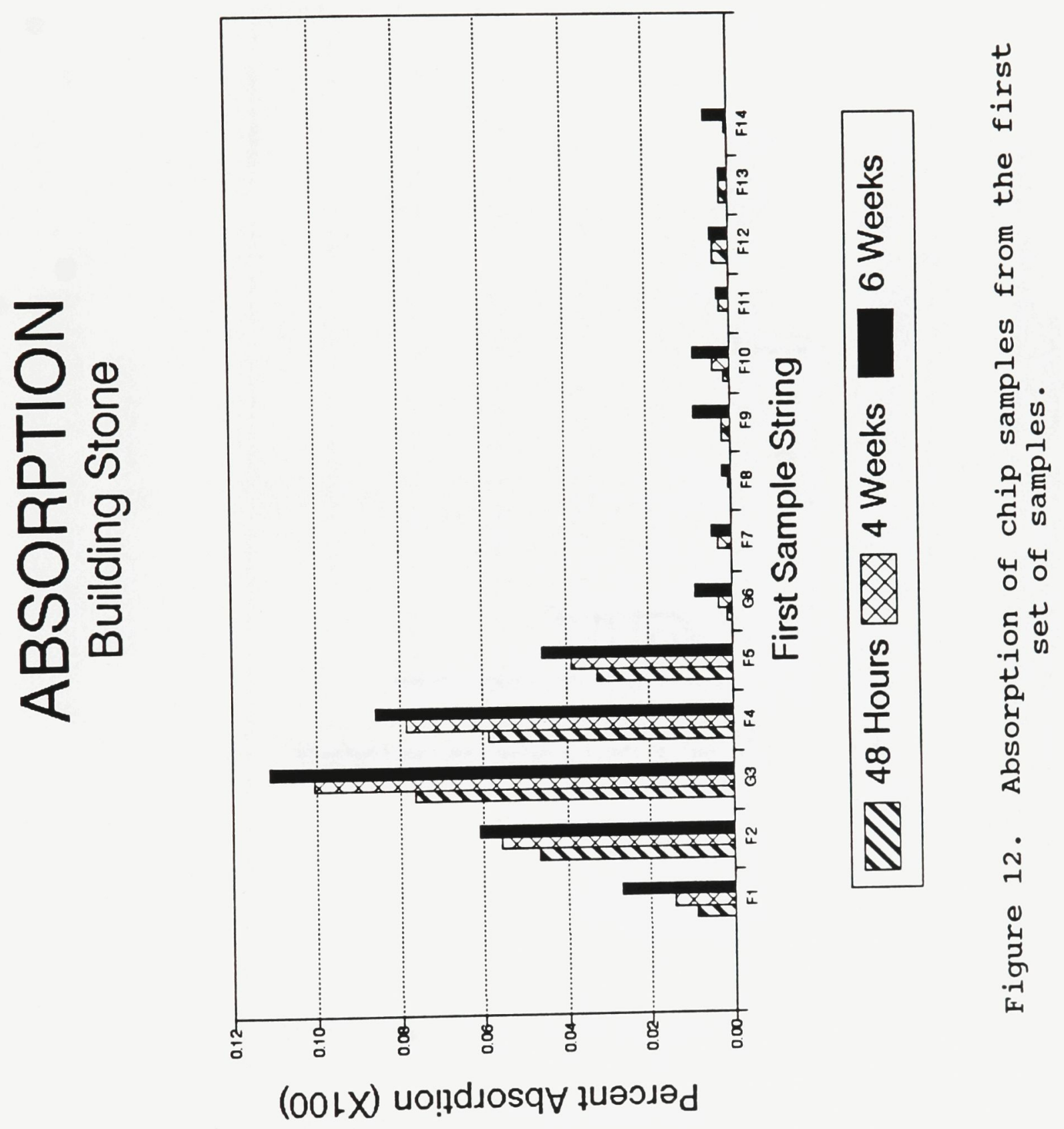




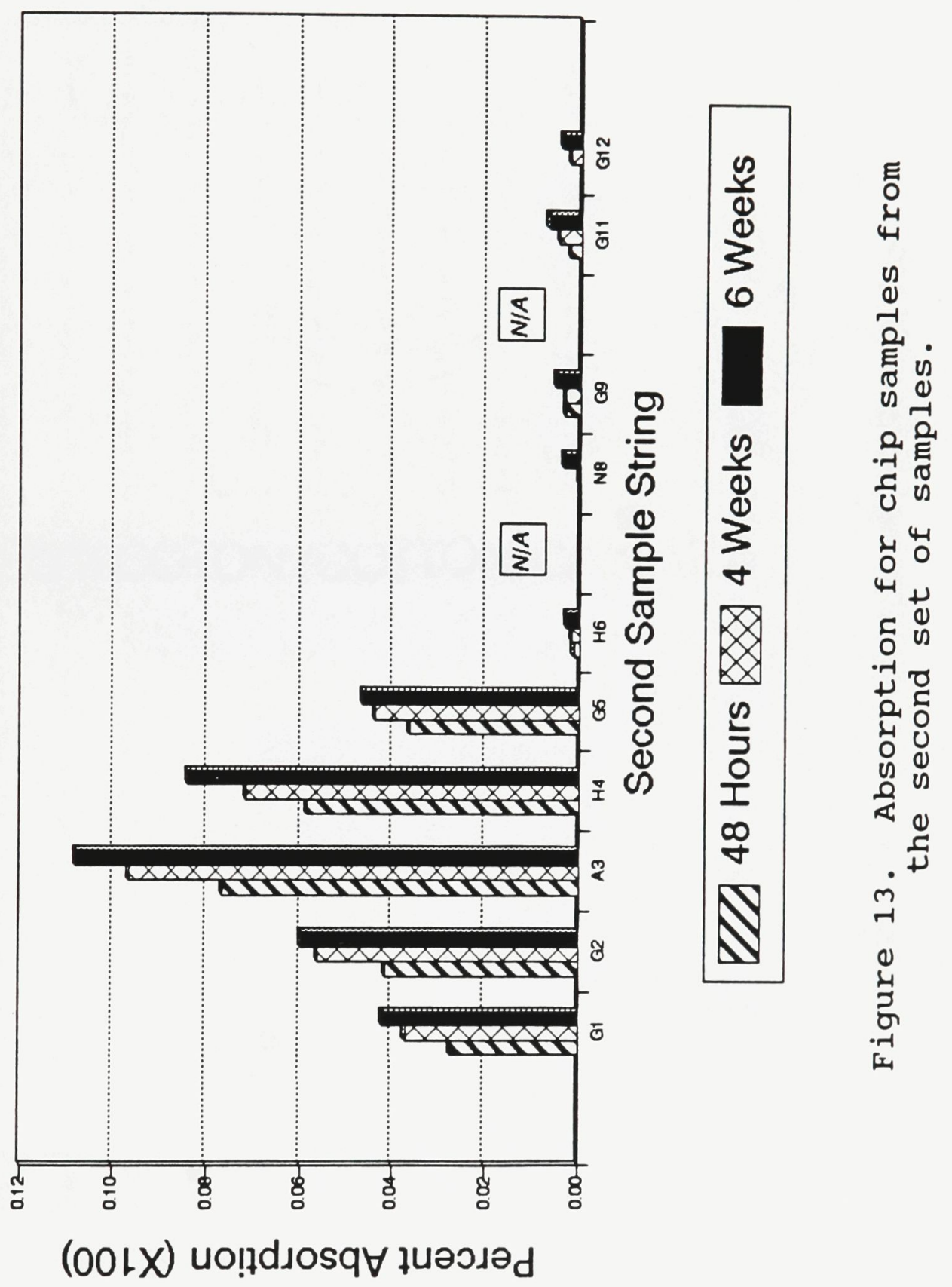




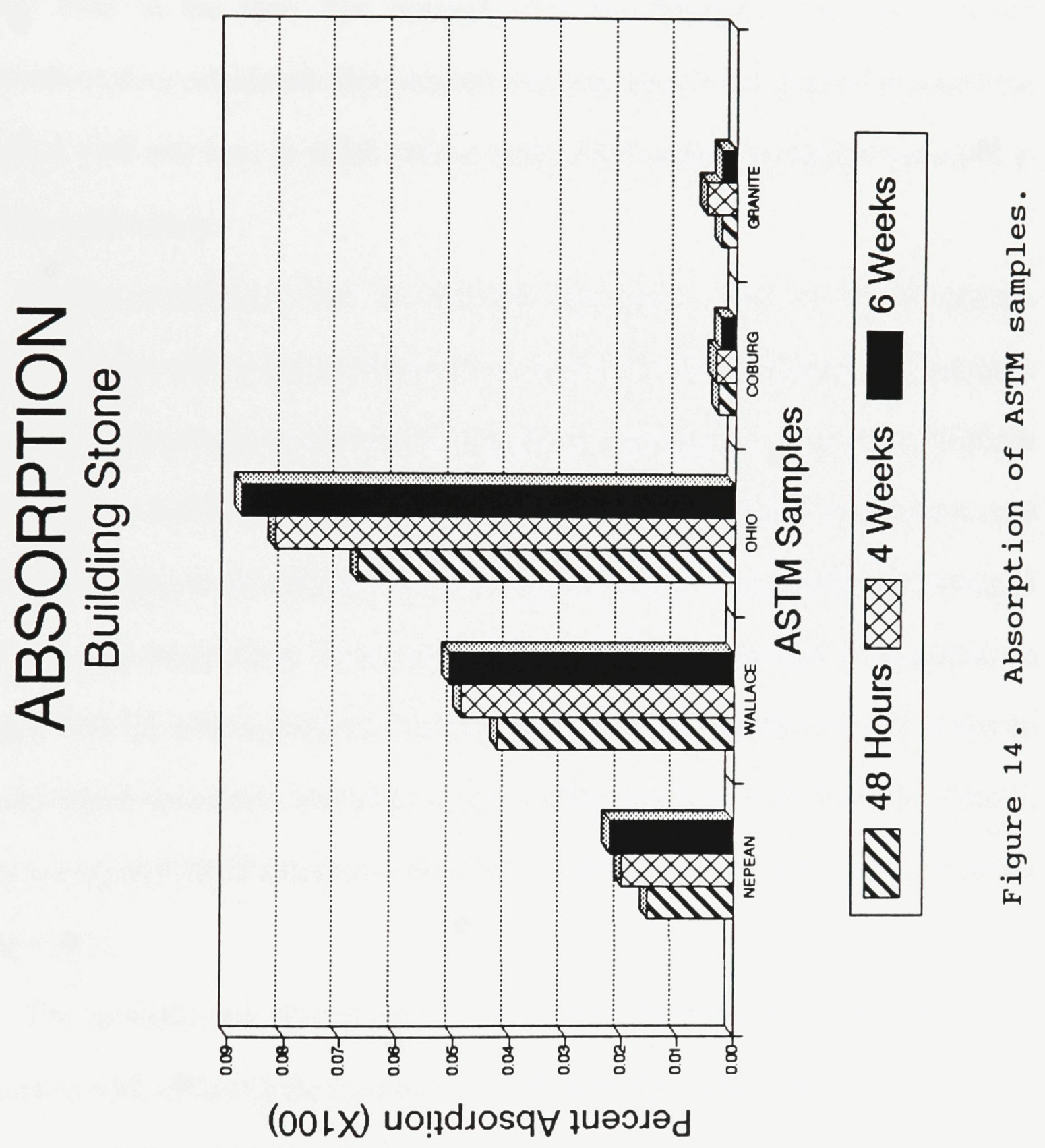


the "droplet test". Figure 15 illustrates this test using the ASTM size blocks. A single drop of water was placed on the surface, and the time required for complete absorption of the drop was recorded. This was then repeated four more times on different sites of the face. The average time for absorption and the standard deviation was then calculated. Evaporation was only considered important where the absorption rate was low, in which case a small, clear plastic container was used to cover the water drop.

Nepean sandstone had an average absorption rate of 0:8:07 (hours: minutes:seconds) with a standard deviation of $0: 13: 11$. This indicates that this rock type varies dramatically in absorption rate from one sample to another. Wallace sandstone has a similar absorption rate of $0: 5: 74$, but the standard deviation is only 0:0:42, indicating it to be a much more consistent rock type. Ohio sandstone averaged 0:0:06 with high consistency. This rock type is thus highly absorbent. Daly limestone averaged $0: 44: 12$, with a standard deviation of $0: 28: 49$. The wide variance is due to fractures which accelerate absorption, not to differences in rock porosity. Finally, granite averaged 0:30:52 minutes to absorb the water drop with a standard deviation of only 0:7:18.

The porosity and distribution in pore sizes for samples $1,2,3,4$, and 6 was determined with an American Instruments 60,000 PSI Mercury Intrusion Porosimeter (MIP) through the courtesy of the National Research Council. A sample chip is submerged in mercury, and increasing increments of pressure are applied to the sample to induce absorption into the different pore size fractions. Figures 16-20 
represent the pore size distribution for samples $1,2,3,4$ and 6 .

Nearly $80 \%$ of the pores in Nepean sandstone are between 55 and 1.75 microns in diameter. The remaining pores are between 1.75 and 0.175 microns. Wallace sandstone has a much wider range of pore sizes, the bulk of which are between 100 and 1.75 microns, the remainder being more evenly spread over 1.75 to 0.015 microns. Ohio sandstone is similar to Nepean sandstone, in that $85 \%$ of the pores are between 100 and 1.75 microns. The remainder are evenly spread over 1.75 to 0.025 microns. Indiana limestone has $35 \%$ pores in the $100-0.88$ micron range, $40 \%$ in the 0.88 to 0.35 micron range, and the remaining $25 \%$ between 0.35 and 0.035 microns. Just under $60 \%$ of the porosity of the Daly limestone is between 55 and 1.75 microns. $23 \%$ of the pores are between 1.75 and 0.07 microns, and nearly $10 \%$ of the pores are between 0.025 and 0.022 microns.

The pore size distribution is a valuable tool in predicting the likely control on physical weathering. Salt can be most destructive where large volumes can be quickly absorbed and recrystallized. This is likely where the pore size is very large, as in the Ohio sandstone. Freeze-thaw cycles are most damaging where the pore size is small (1-.1 microns). This is because large pores tend to drain rather than build up with water, and in large pores there is often enough space for expansion of water. Thus, Nepean and Ohio sandstones are more vulnerable to salt weathering and Wallace, Indiana, and Daly rocks are more vulnerable to the freezing of pore water. 


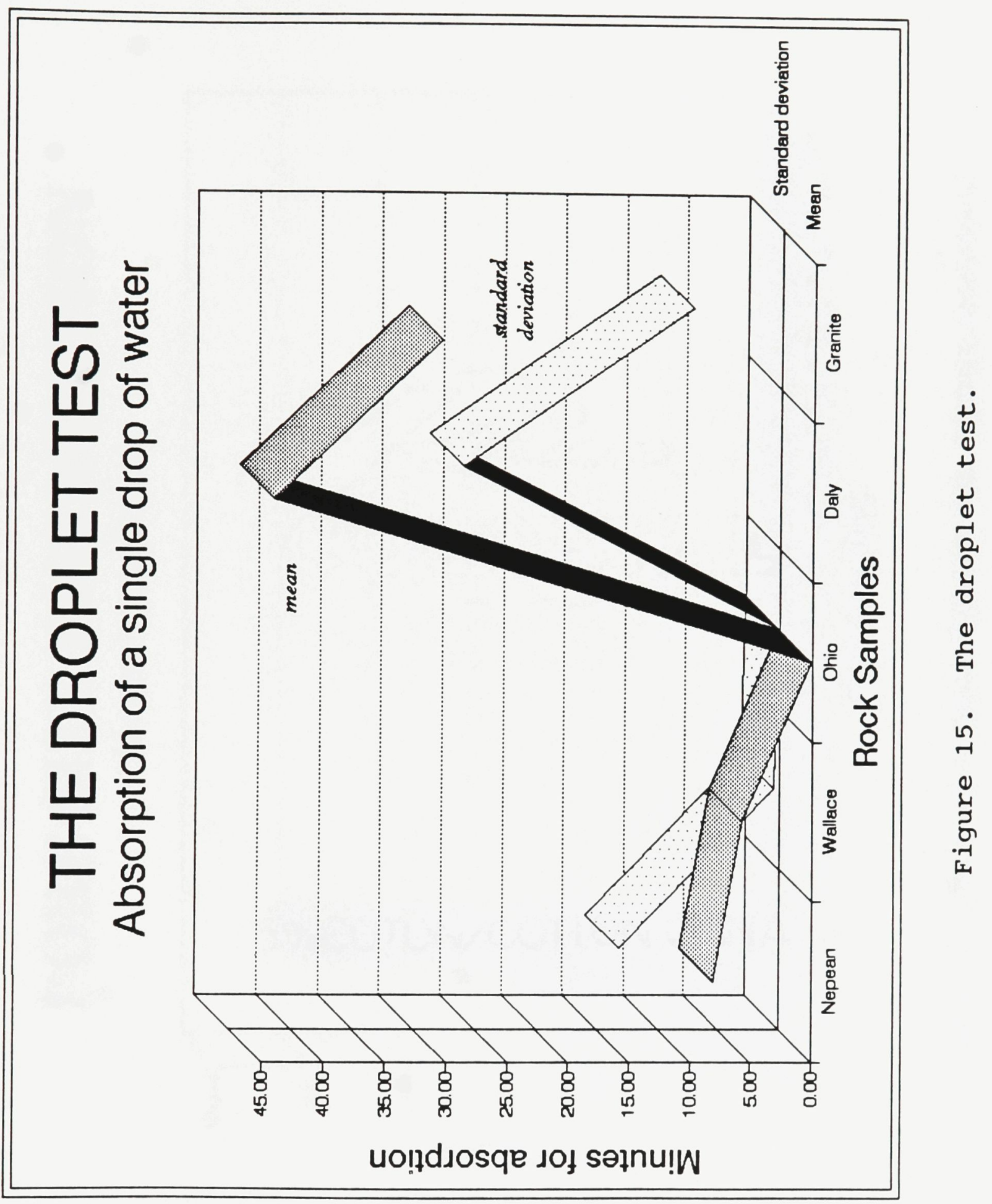




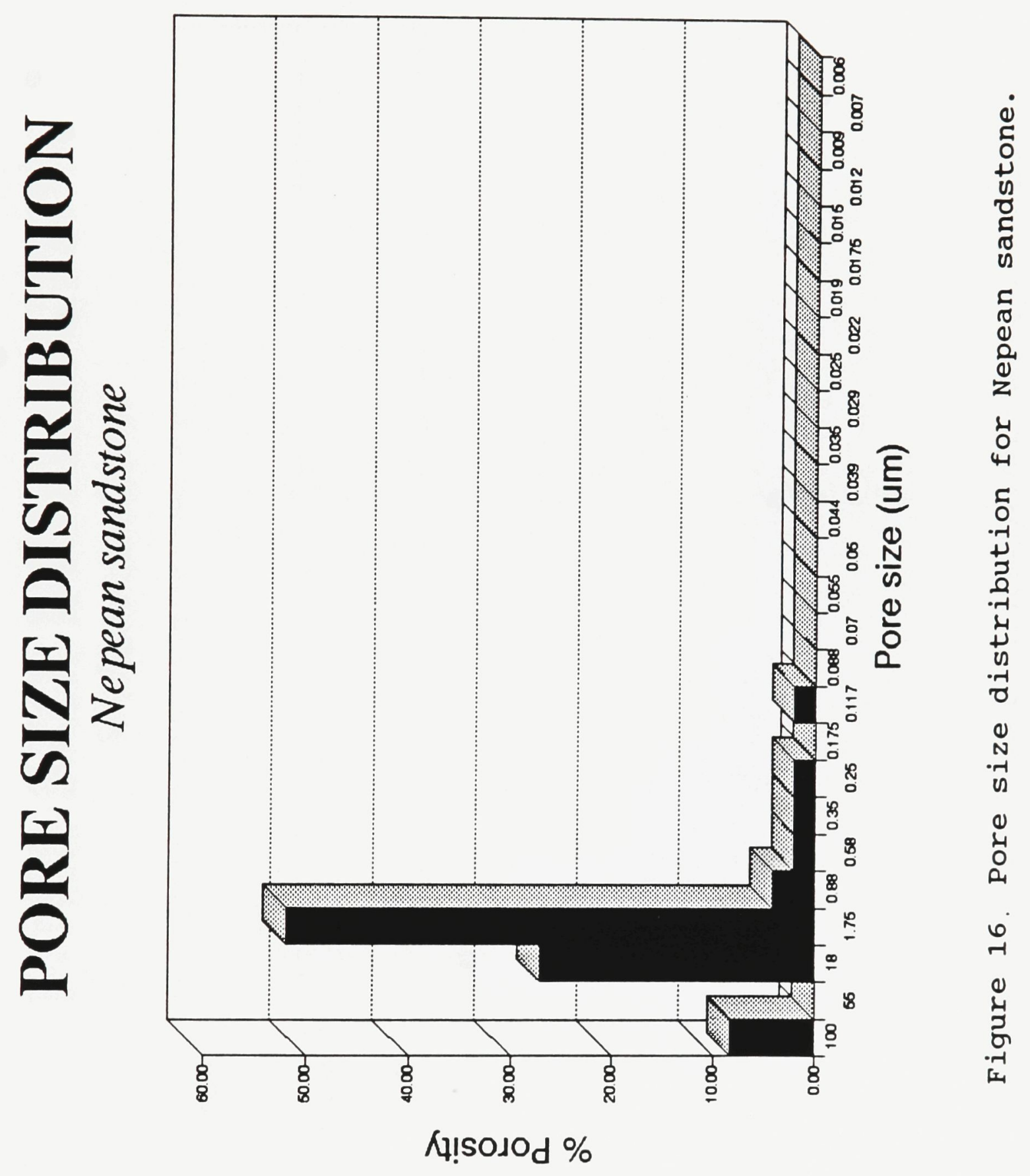




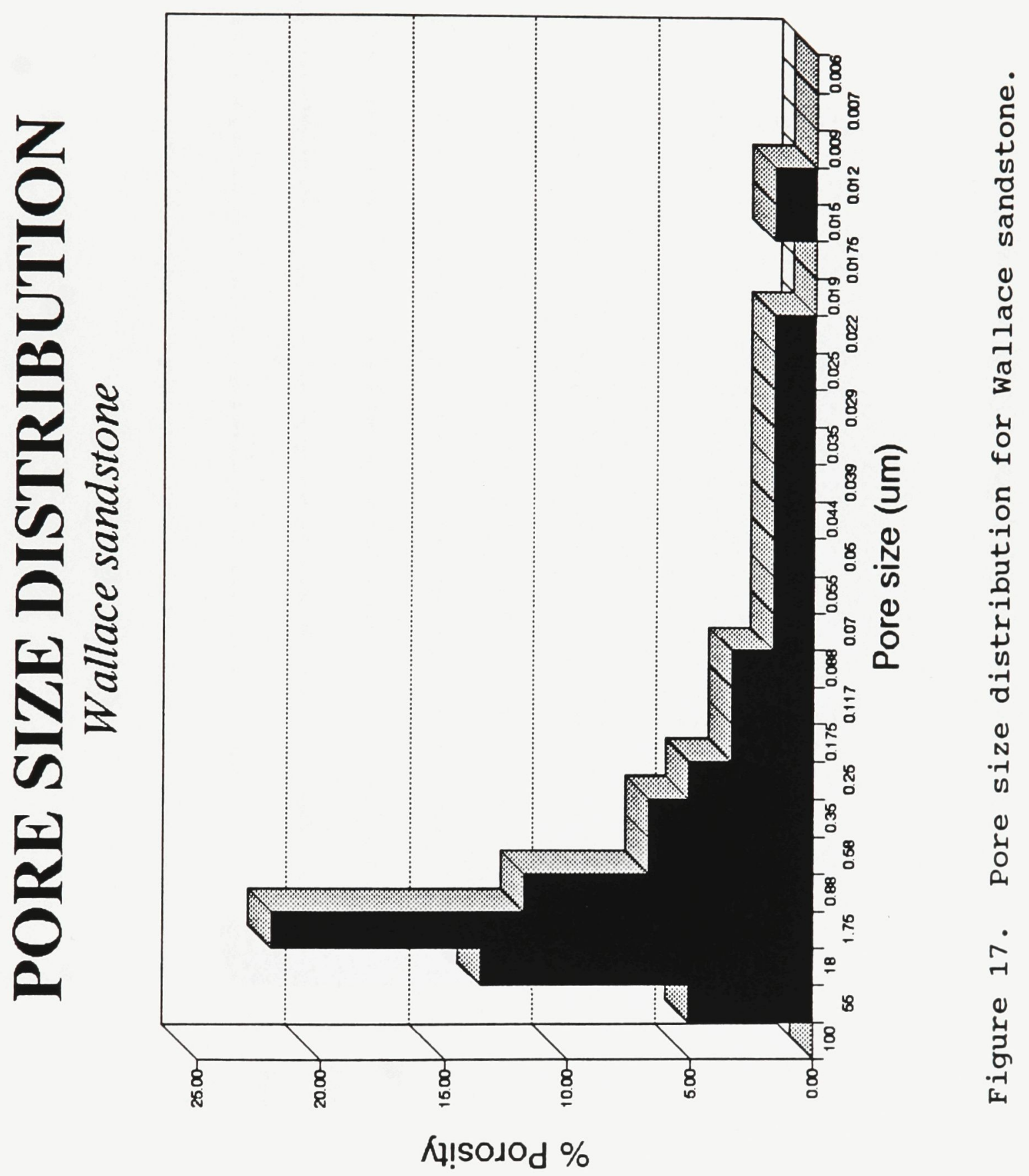




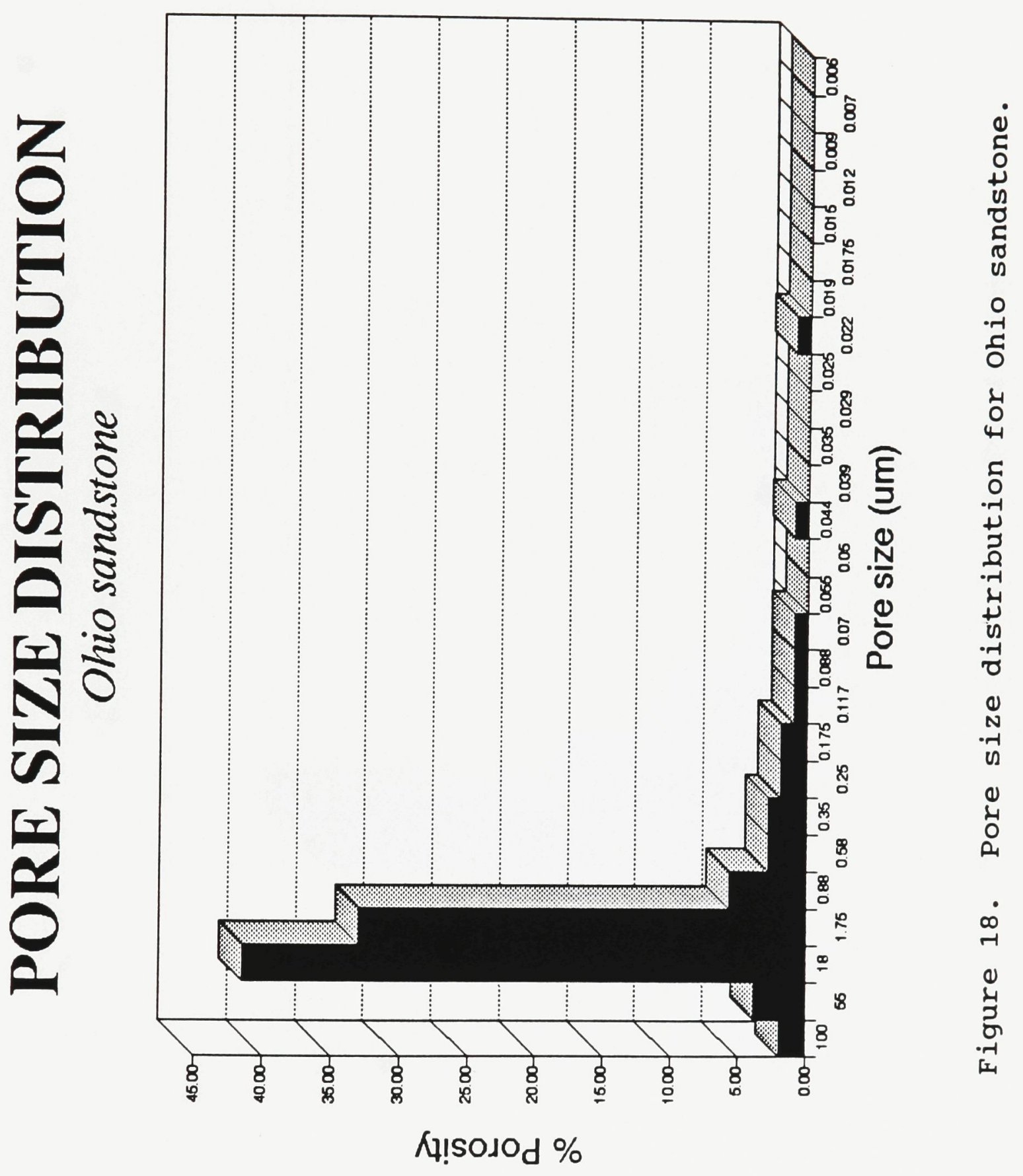




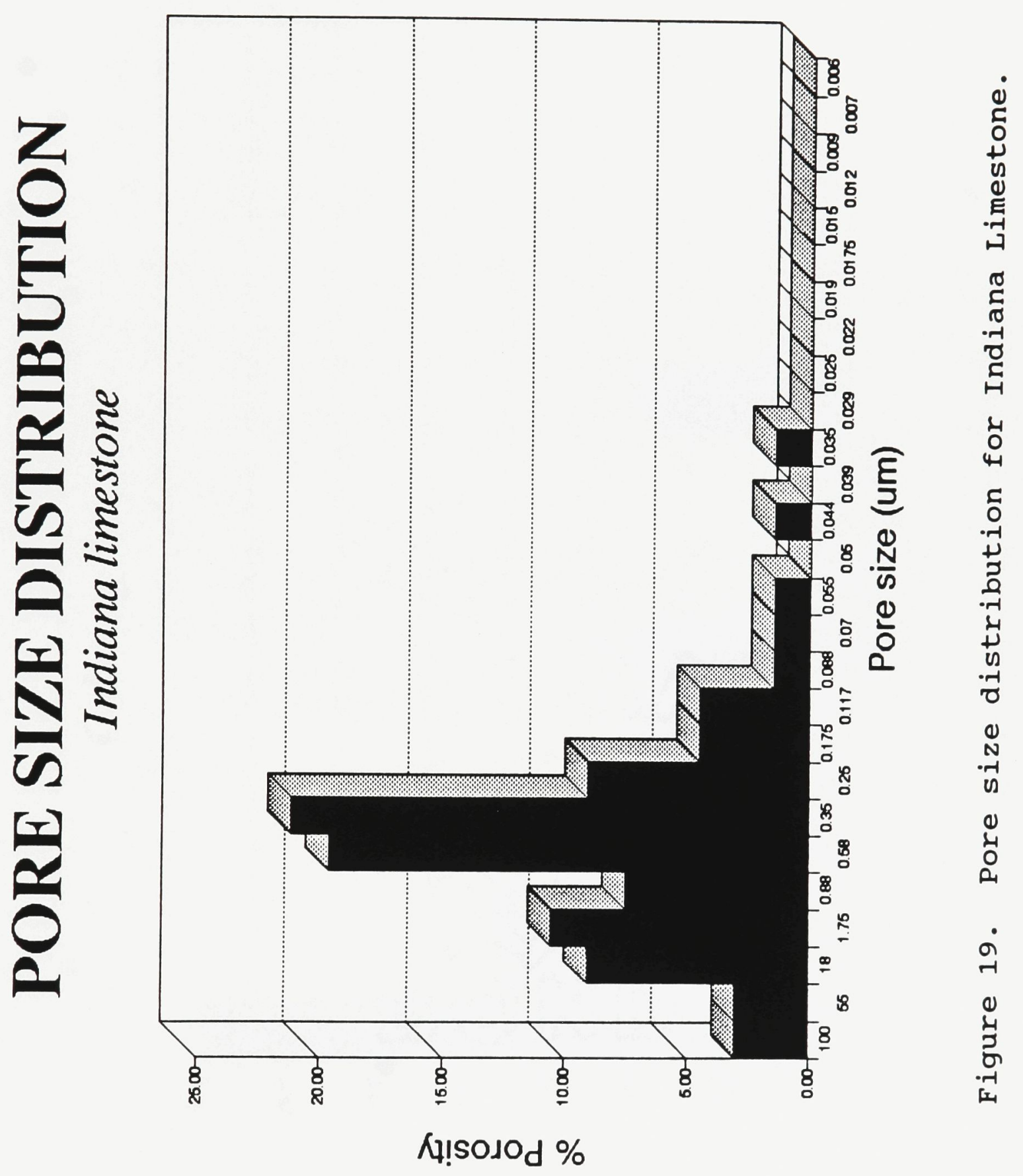




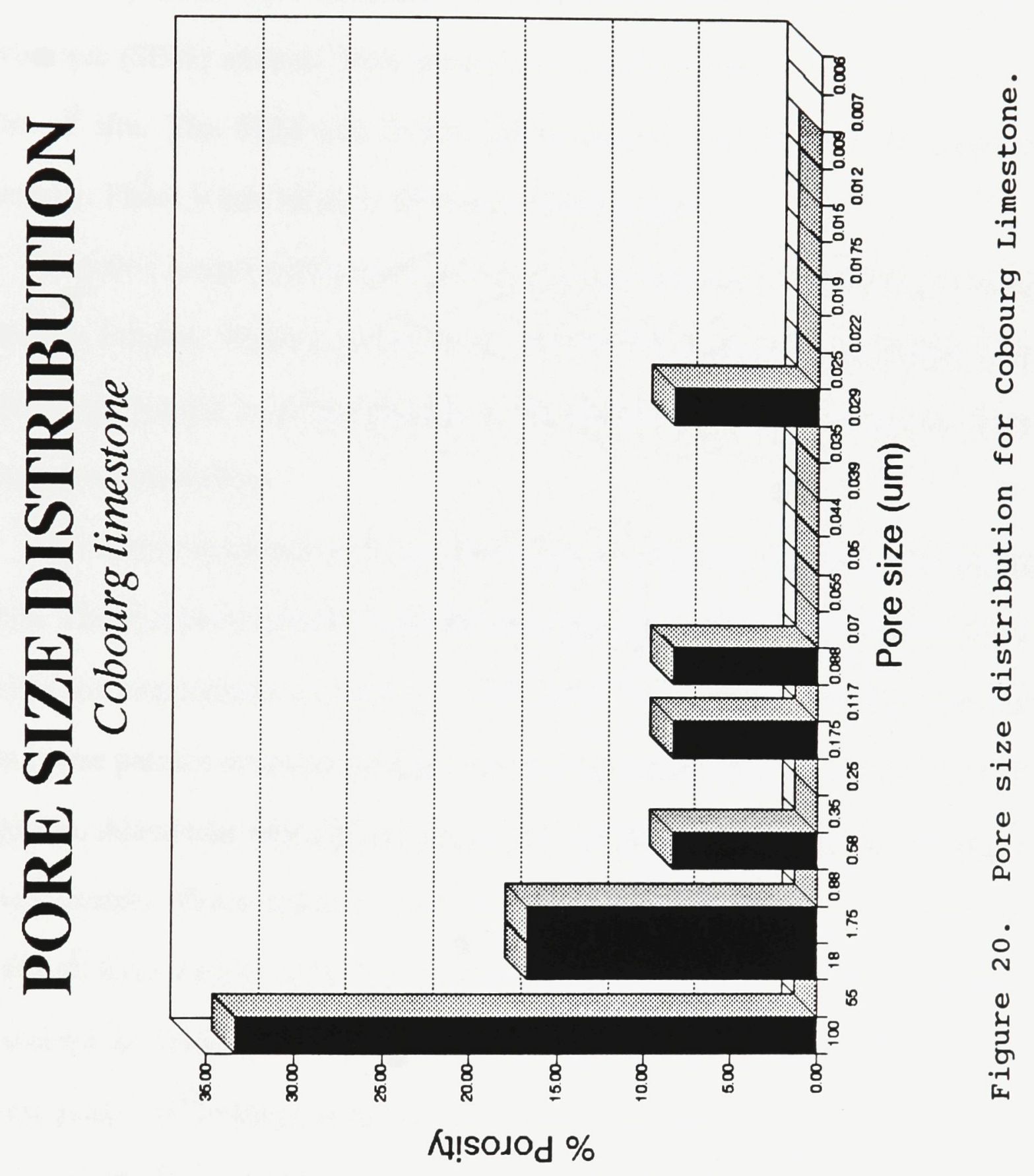




\subsection{Scanning Electron Microscopy}

Two samples of surface-discoloured (a thin veneer of soot over minor white efflorescence) stone were collected from Parliament Hill for scanning electron microscopic (SEM) analysis. Both samples were collected from spalled surfaces of blocks in situ. The SEM and X-Ray diffractometer was operated at Carleton University. Plates 9 and 10 show SEM microphotographs.

Sample 1 is a grey efflorescence coating on sandstone collected from the stone fence that borders Wellington Street in front of the Parliament buildings. This material was ground to a fine powder to distinguish the different particles. Four features became evident.

The main constituent of the powder is gypsum which forms masses and bladed crystals. The spectrum indicates enrichment in calcium, sulphur and oxygen, which matches the composition of gypsum, $\mathrm{CaSO}_{4} \cdot 2 \mathrm{H}_{2} \mathrm{O}$. Colloidal carbon-rich material forms sparse patches or masses with spectra showing an enrichment in carbon as well as gypsum. Aluminum and silicon spheres are common, resting on and within the gypsum crystals. These spheres could be related to sand-blasting from cleaning operations. Rare strands of linked thread-like matter is presumed to be biological. The spectra for these strands indicate carbon and oxygen enrichment, but distinct spectral peaks are lacking, probably due to the small size and the dominance of gypsum crystals. Some features for sample 1 are illustrated in Plate 9.

The second sample is a thin chip of Ohio sandstone with a black coating. This sample, dislodged from the building block by surface spalling, was collected $1.5 \mathrm{~m}$ 
above the ground on the north wall at the northwest corner of the West Block. The chip was viewed as a whole-mount. The principal mineral is quartz, but this is blanketed with a colloidal black coating of iron and some carbon. The margin between the coating and the sandstone is sharp and easily cleaved. Similar to sample 1, a few strands of biological material and spores were seen. Plate $10 \mathrm{~A}$ shows a smooth colloidal surface coating on (sample 2) sandstone which is iron and carbon enriched along with aluminum, silicon, and oxygen. Plate 10B (also sample 2) displays the colloidal surface coat, but with a chip removed, exposing an underlying quartz grain. This coating is also iron-rich.

Sample 2 shows the presence of an iron-rich colloidal surface coating. The black colour is probably due to fine carbon dust collecting on the iron coating. The colloidal nature of the iron coating suggests a biological source. The erratic nature of carbon masses could indicate airborne particulates that cling to the colloidal crust.

\subsection{Experiments.}

Three experiments were conducted to determine susceptibilities for each rock type to: acids; freeze/thaw cycles with salt water, and; wet/dry cycles with salt water. These experiments simply provide an indication of the relative degrees of sensitivity, rather than absolute rates or measures.

The acid test employed a $3 \%$ solution of $\mathrm{HCl}$ in which small chip samples were placed at room temperature for 24 hours. This concentration of acid was sufficient to dissintegrate a significant portion of the carbonate samples, but not 
completely consume them. The samples were then dried and weighed, and their weights compared to their original weights. The results are illustrated in Figure 21 and tabulated in Appendix I.

Limestones and marbles were predictably affected the most, losing as much as $13 \%$ of their mass. Sandstones that contain some carbonate were slightly corroded and the remaining samples were relatively untouched.

The freeze/thaw experiment utilized a saline bath averaging $8 \% \mathrm{NaCl}$ in which the samples were soaked, withdrawn, and then allowed to freeze to $-30^{\circ} \mathrm{C}$. The cycle of freezing and thawing (to $20^{\circ} \mathrm{C}$ ) was repeated approximately once every 12 hours. Re-soaking in the saline solution was repeated every five cycles. Observations were made about where the salt precipitated and any damage that had occurred. At the end of the experiment, the samples were dried and rubbed with a soft bristle-brush to remove loose surface grains. Weights were measured to determine the amount of loosened and removed framework from salt and ice crystallization.

Wet/dry cycles were monitored for samples that were soaked in a $5-20 \% \mathrm{NaCl}$ solution. Water baths originally measured about $20 \% \mathrm{NaCl}$, but reduced in concentration to about $5 \%$ after several cycles. This was arranged to simulate periodic salt deposition and concentration fluctuations at entrances and along roadways. The concentrations are not as important as the uniform treatment of all samples, as this was a test of relative impact. After the drying process ( 9 hours), samples were rubbed with a soft brush to remove any loose grains on the surface. This process allowed greater penetration of the salt crystals and accelerated scaling. 
Measurements were made of the pre- and post-experiment weights. Mass loss results are illustrated in Figure 22.

The average loss for wet/dry cycling was $1.0 \%$ (by weight) whereas for freeze/thaw cycling, the average loss was $0.8 \%$. This difference is possibly accounted for by abrasion of the wet/dry samples after each cycle, which would accelerate weathering. Samples $1,3,4,5,7,11,12$, and 13 were more affected by wet/dry cycling and samples $2,6,8,9,10$, and 14 were more affected by freeze/thaw cycling. Only samples 3 and 4 showed significant discrepancies; all others had similar losses between the two tests. The overall trend indicates that the samples with greatest porosity were most affected; however, the fact that Indiana limestone was more affected than Ohio sandstone indicates that the pore size is a more important factor than overall porosity. It is surprising that Nepean and Wallace sandstones showed as much resistance as the granites. The trend of each test is confirmed by the trend of the other test.

According to these results, Indiana limestone and Ohio sandstone are the least resistant to frost and salt weathering. Nepean sandstone is remarkably resistant; however, the variability of Nepean sandstone suggests that repetition with several samples would undoubtedly give diverse results. 
Plate 9.

A. Weathered grain with sooty patches (A).

B. Possible strand of biological material (B) amongst gypsum crystals (G). 

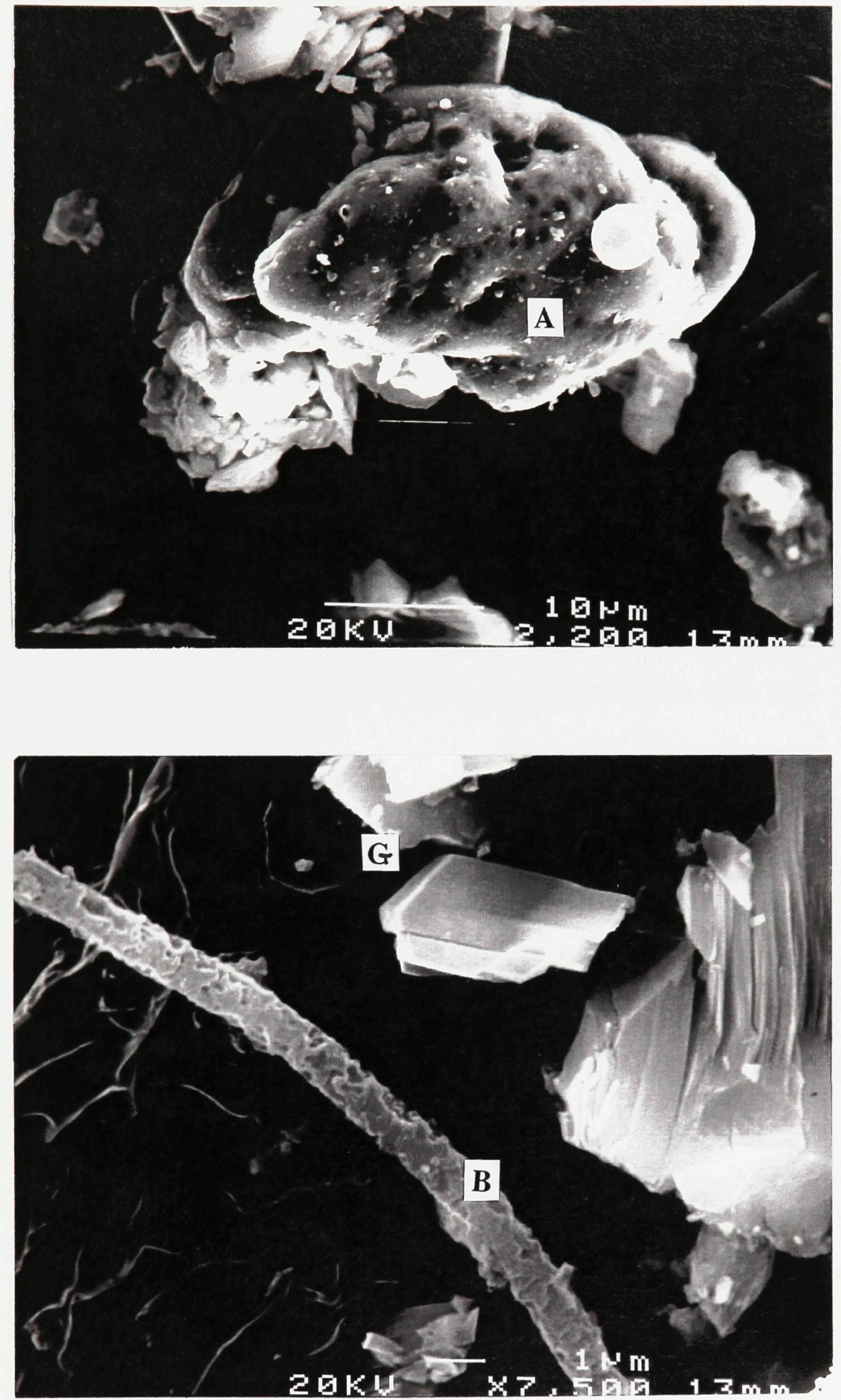
Plate 10.

A. The edge of the surface crust on sandstone.

B. A chip of quartz (Q) is exposed in this colloidal surface coat (C). 

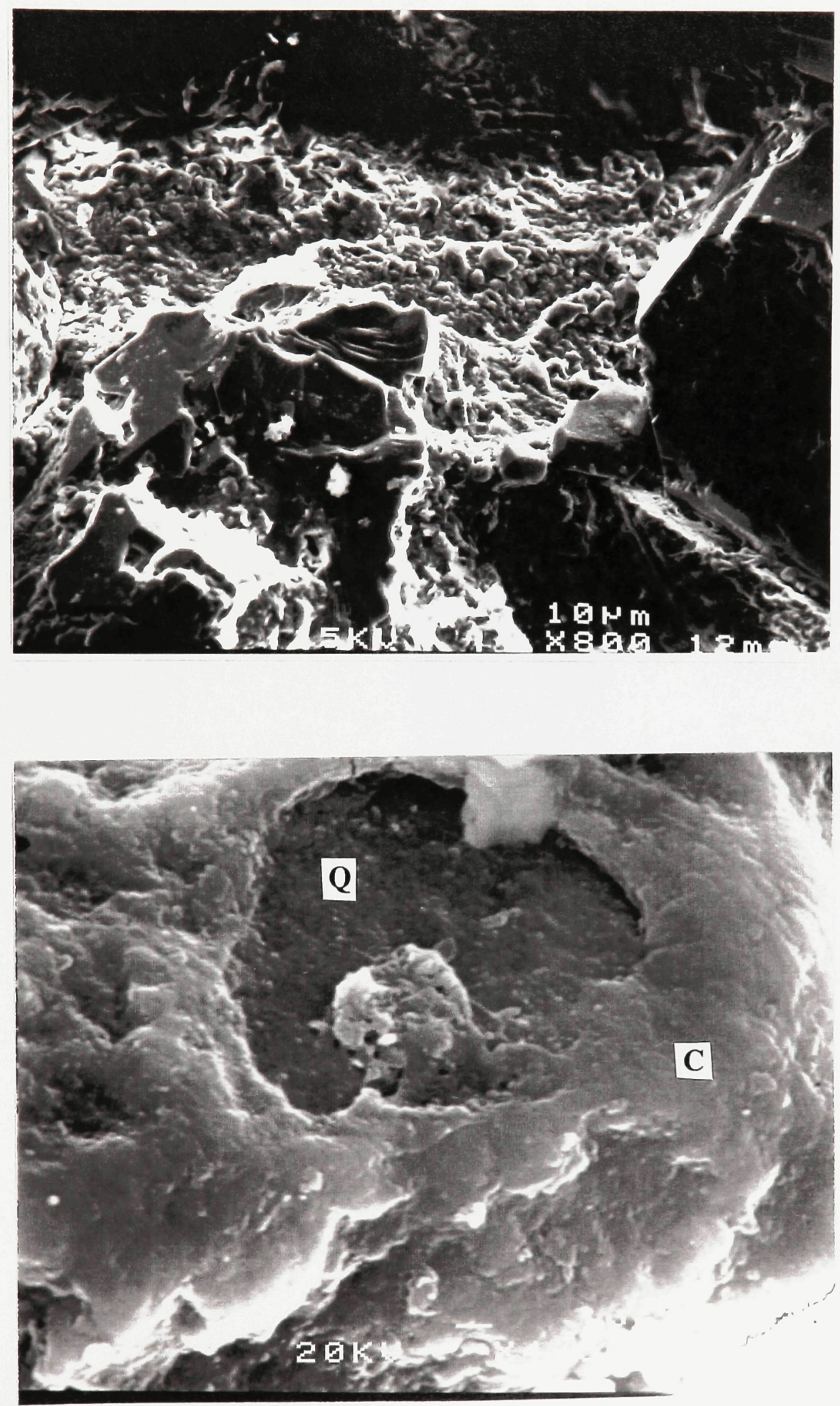


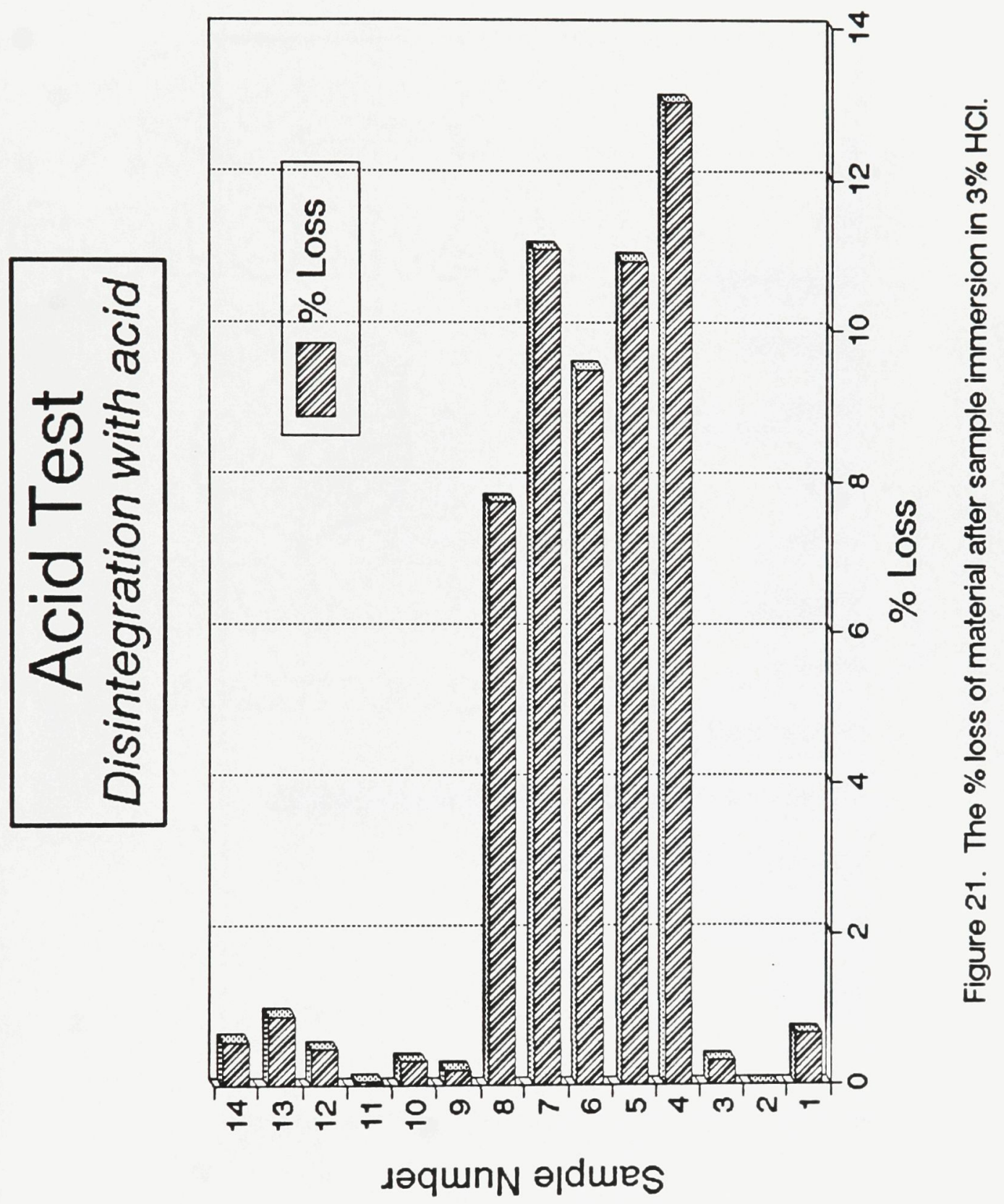




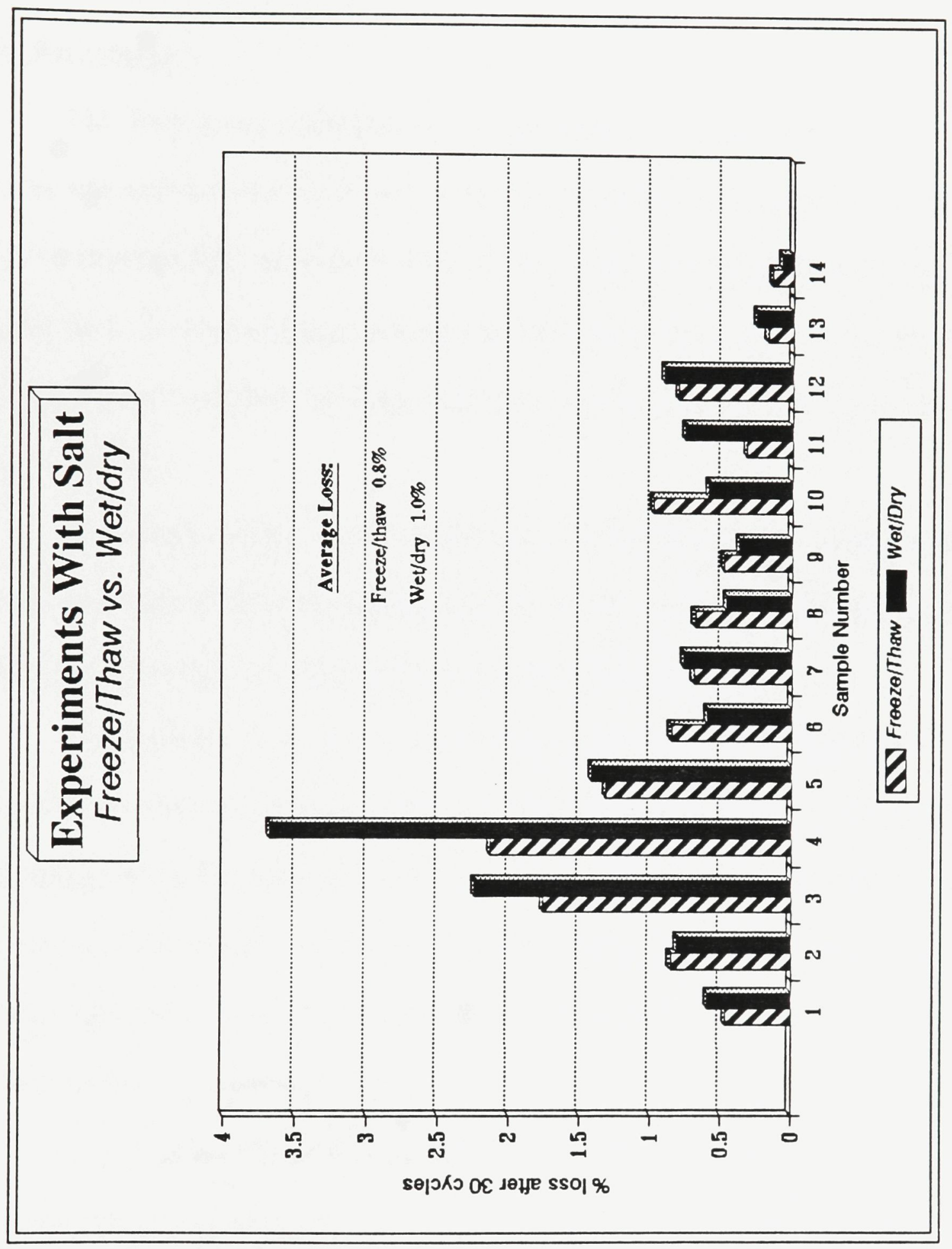

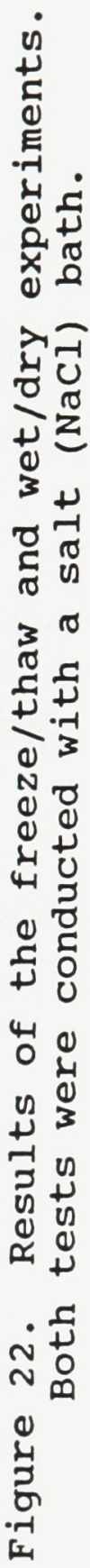




\section{Chapter 5. Weathering Features}

\section{$\underline{5.1 \text { Parliament. }}$}

The Parliament buildings were constructed between 1860 and 1867. The library was added to the north side of the Centre Block and completed in 1877 . The site, Parliament Hill, consists of 29 acres $(11.7 \mathrm{Ha})$ in central Ottawa, and stands higher than its surroundings, jutting out into the Ottawa River. The Parliament buildings consist of three buildings that form a quadrangle occupying an area of 9.5 acres $(3.84 \mathrm{Ha})$.

The Centre block, on the north part of Parliament Hill, incorporates the House of Commons and the attached library on the north side. This building faces south, has a frontage of $143 \mathrm{~m}$ and at the widest point is $113 \mathrm{~m}$.

The building to the east of Centre Block, the East Block, forms a rectangle $97 \mathrm{~m}$ by $75 \mathrm{~m}$. The West Block, to the west of Centre Block, forms an "L" shape $84 \mathrm{~m}$ of frontage along the south side and $67 \mathrm{~m}$ along the quadrangle (east side). In 1876 , an area of 1579 square metres was added to the west block to accommodate new offices. Originally two-storey buildings, the basements and attics were added to provide additional office space in 1877 .

In 1916, a fire destroyed the entire Centre Block, excluding the library. The structure was completely demolished and rebuilt with new stone. The Peace tower, which rises 291 feet at the south central front of the Centre Block, was added during reconstruction from 1919-1927. During this time, members of parliament were moved 
to the Victoria Museum where parliament was temporarily housed.

The Parliament buildings were built in the Pointed Gothic style, with gables and statues overhanging the walls. The main building block is Nepean sandstone, but Ohio sandstone was used for window frames, sills, some railings on staircases, cornices, and other ornate blocks. Potsdam sandstone was used sparingly for relieving arches. The peace tower is composed of Nepean sandstone and Wallace sandstone, the Wallace blocks serving the same functions as Ohio sandstone in the rest of Parliament.

The exterior walls of the Parliament Buildings are doubly plied, with sandstone outer-facing and local limestone inner walls. The original mortar is now considered to be excessively rigid, and much of the new pointing employs a softer mortar that will expand, contract and shift with movement. The Peace Tower is mainly composed of Nepean sandstone, but with corner blocks and window dressings of Wallace sandstone. This structure is backed with five feet of concrete except between the floor level of the clock chamber and the spire, which is solid stone.

Most ornaments and plaques on the buidlings were carved from Ohio sandstone. Indiana limestone was used for interior plaques, statues, and some exterior window frames and stair rails. The interior of the Centre Block is lined with polished Tyndall limestone. Monument bases, steps, and sidewalks are generally made of Hampstead granite or Stanstead granite.

Because the architects wanted asymmetry within each building and between the buildings, blocks of each type of rock occasionally occupy unexpected places. 
Wallace sandstone occupies the lowest parts of the entries into the Centre Block, topped by Ohio sandstone. Wallace sandstone was also used in stone fences across the front of the Centre Block. Indiana limestone was used as stair rails for the Library. In general, Nepean sandstone was used as core building blocks for the colour and texture that forms the walls of the buildings. Wallace or Ohio were used where larger, flat faced blocks were needed with uniform qualities, such as around windows and at corners. Ohio sandstone was used for blocks carved into intricate forms, such as rails and piers.

Due to the heterogeneous nature of the Parliament buildings, a wide variety of weathering features were observed. Some features are characteristic of a particular rock type; others are common to groups of rock types.

Nepean sandstone tends to vary in weathering more than any other rock type. This is due to variations in porosity, bedding, and other structures. Differential weathering resulting in layered relief parallel to bedding is common (Plate $11 \mathrm{~A}$ ), with more silicious beds standing out relative to the carbonate-cemented beds. Iron oxide accumulation is also quite common. Most of the iron oxide is probably derived from crystals of pyrite which are common in some blocks. The formation of iron oxide, although perhaps minor, serves to disrupt the cement and grains. Some blocks of Nepean sandstone display pockets where carbonate- rich pods have dissolved, leaving space for soot, bacteria, and plants to accumulate.

Wallace sandstone tends to recess along bedding or tool mark lines. In addition, most blocks show physical weathering features that are recessed due to 
spalling or scaling in the middle of the block, or on one side toward the edge of corner blocks. When soaked, salt ions from de-icing salts, mortar, or natural salts in the stone move with the water as the stone continues to dry. Drying begins at the edges and salt migrates into the centre where it eventually precipitates. Subflorescence takes place and disrupts the grains. Subsequent rain and wind remove the loosened particles, leaving a depression in the centre of the stone face (Plate 11B).

Ohio sandstone also shows recession along tool marks and bedding. The bedding in Ohio sandstone commonly displays ripples and cross-bedding, and recession is widespread along these structures.

Salt weathering is one of the most notable and destructive mechanisms in building stone of the Parliament buildings. This is most conspicuous in Ohio sandstone at the base of entry arches. The lowermost stone block is Wallace, which shows little damage due to the salt. The overlying block is Ohio sandstone, which exhibits severe loss. The entries are laden with de-icing salt $(\mathrm{NaCl})$ in the winter, which migrates up the pillars by capillary action to the Ohio sandstone, where it is absorbed. The build-up is so dramatic, that thick crusts of $\mathrm{NaCl}$ were visible in August lining corners and faces of the pillars (Plate 12A).

$\mathrm{NaCl}$ efflorescence was also observed in pockets of Nepean sandstone, creating deep holes and differential weathering. Salt can travel up the mortar joints and be selectively absorbed where the porosity is greatest. Some blocks of Wallace display efflorescence as thin coatings around centres of spalling. 
A second salt in much lesser quantity also effloresces on Wallace sandstone. This salt, thenardite $\left(\mathrm{NaSO}_{4}\right)$, could be the result of natural salts in the stone, or the recombination of ions from mortar and stone.

On many faces of stone, especially Wallace sandstone, mortar has been spread during restoration work to encase the face of highly weathered stone, with the intention of slowing the weathering process. However, the process of weathering has instead accelerated. Once the face of the stone was enclosed, water could be retained in the rock more easily. The combination of water and mortar has resulted in the formation of gypsum and carbonic acid which not only reacts at the surface, but within the block. Consequently, the mortar sheath is readily removed by gypsum crystallization, and the sandstone can be further disrupted by leaching of the framework and cement. This type of degradation can be seen in Plate 12B.

The most extensive deterioration from gypsum is within the centres of gables and around hollows of ornately sculptured sandstone. Water tends to migrate to, and accumulate within, these protected environments. The lack of flushing water allows gypsum crystals to continue to precipitate unchecked, producing a ragged decaying facade. The source of this gypsum is probably from the mortar or the limestone inner wall (Plate 13A).

Among the carbonates, Indiana limestone demonstrates the effect of chemical dissolution most strikingly where ornate figures are worn down. Old gargoyles and figures have lost many features in less than seventy years. The underside of sloping arches above the Library are made of limestone, probably of local origin. Within 
some of these blocks, stylolites and bedding fractures have accelerated weathering.

Granite steps and walkways exhibit two distinct features that are probably to some degree related. The edges of blocks are chipped. A distinct iron oxide stain develops along the outer edge about three inches in from the rim. As water evaporates from the edges and migrates inward, iron oxide will also migrate along the same path to a point in which the concentration forces the iron oxide to precipitate along the water line. Granite will chip along the edge partly due to salt and frost expansion, and partly due to expansion caused by the formation of iron oxide from iron-rich minerals. However, some of the damage may be due to snow-plowing (Plate 13B).

Black soot is common on building blocks at Parliament, but some blocks appear to be more vulnerable than others. Two explanations can account for this inconsistency: 1. Blocks are attacked because of their configuration, and; 2. blocks are attacked because of their internal characteristics.

Nepean sandstone is highly variable in soot accumulation. Some blocks are black while others appear fresh. Most blocks that are low to the ground and face east or are in sheltered nooks tend to be black. Plate 14 illustrates the effect of direction on soot build-up at the southwest entrance on the south side of the Centre Block. The west face of the entry is relatively clean of soot. The south face is slightly more sooty, but the east face is black. The influence of wind and sun on drying is conspicuous. Of the blocks higher off the ground, the variation in soot build-up is more striking. This can be explained by the wide variation in porosity. Some Nepean 
blocks are porous, whereas others, or layers within them, are impervious.

Ohio and Wallace sandstone on the other hand, are consistently blackened or consistently fresh, depending on location and orientation. Ohio sandstone clearly demonstrates the importance of orientation and site location for accumulation of soot. Plate $15 \mathrm{~A}$ illustrates the orientation of step blocks on a pier which consistently attract and accumulate soot. The angled blocks below the cornice have clean faces just under the cornice lip, where, sheltered from flushing water, gypsum crystals promote continual spalling. A dark line forms at the top of the sooty face, and small sooty lobes develop where overlying seams are located. This is a result of higher moisture content and movement. The black line below the cornice is the drip line. Angled step blocks on piers are darker where the angle of inclination is lower. This can indicate longer periods of moisture retention and snow buildup.

Biological weathering is only a significant factor on the north faces of the Parliament buildings or near ground level. This is especially so at the Library, perhaps because of the exposure to dampness from the river. Mosses frequently inhabit mortar joints and pockets or fractures in rocks on the north side. Nepean sandstone is best suited to biological weathering due to the irregular surface and the pockets of porous material. In several places, moss has completely disintegrated both the mortar and the outer few centimetres of calcareous Nepean sandstone (Plate 15B).

An experiment was performed to determine if the moss was accelerating corrosion of the mortar by acidity. A clump of moss was removed from between 
Nepean sandstone blocks. The moss was secured in mortar that had completely broken-down to sand. Both the moss and the disintegrated mortar were separately crushed in de-ionized water and measured for $\mathrm{pH}$. In addition, a consolidated piece of mortar not affected by moss was analyzed.

The moss and hyphae had a neutral $\mathrm{pH}$, slightly more acidic than the mortar. Although the result is inconclusive (Figure 23). However, it is evident that the neutral $\mathrm{pH}$ of the moss roots may affect water $\mathrm{pH}$, and thus promote dissolution of the mortar. Roots of the moss were observed to be completely intergrown with the softened mortar, indicating slow but persistent physical as well as chemical destruction.

Other organisms that inhabit the rock surfaces include moths, spiders, and other insects which build cocoons or nests in the hollows. Bird droppings are common in some areas, especially along the tops of sills, and could lead to the formation of salts or acids if not removed by rain-water. 


\section{pH level of moss and mortar}

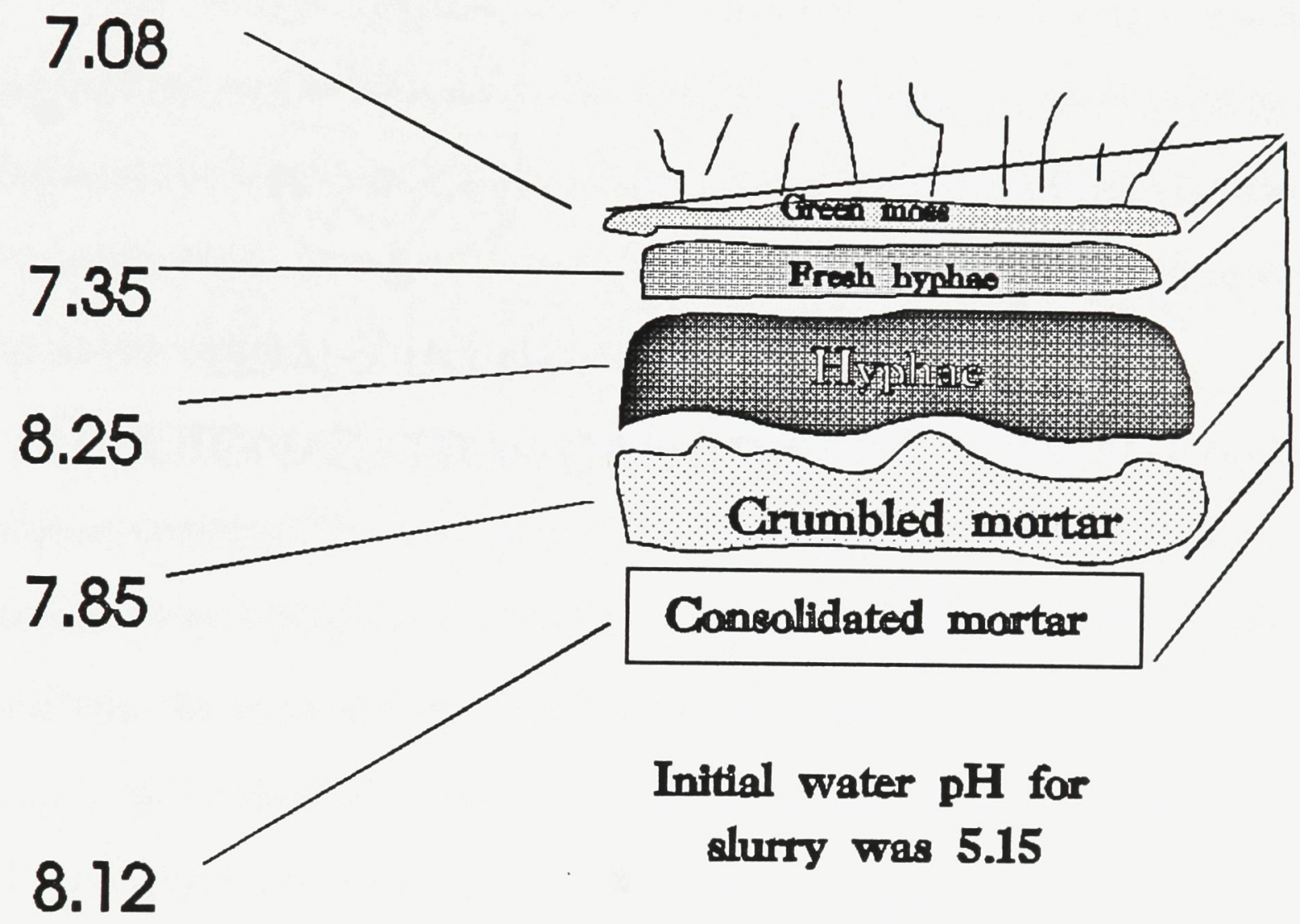

Figure 21. Mllustration of $\mathrm{pl}$ il of moss and mortar 


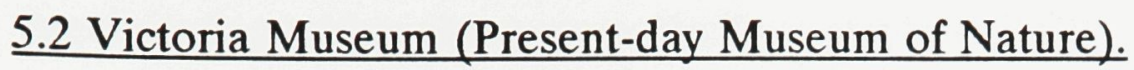

The Victoria Museum was built in $1905-1912$ in the castlesque style. The building occupies roughly 3 acres south of the junction of McLeod and Metcalfe Streets. The site is relatively low and surrounded by large deciduous trees, low-rise buildings, and moderate urban traffic. The building is roughly square and rises 4 stories.

The Victoria Museum has been the focus of several recent structural investigations due to shifting of the foundation, and surface weathering. Unlike the Parliament buildings, cleaning was performed on the building about 20 years ago, to remove the build-up of soot. Features seen in this building are similar to those of the Parliament buildings, but under slightly different conditions.

The Victoria Museum was constructed with exterior walls of Nepean and Wallace sandstone. The foundation is of local limestone, and the steps are made of granite. Many features in the building stone are the same as in the Parliament buildings. The most striking weathering feature is gypsum and other salt scaling within edge blocks of butresses. This scaling commonly forms only on one side, the side better protected from the wind and sunshine, or the side which is last to dry. Drying draws the salt toward the last moist portion of the stone where precipitation takes place. Butresses are constructed with Wallace sandstone corner blocks and a central strand of Nepean sandstone. It is common to see spalling in Wallace blocks only on one side and adjacent to the central Nepean blocks. This is most likely caused by winds pushing gypsum or other salts toward the core in one direction and 
precipitating within the porous Wallace sandstone (Plate 16A). Another prominent location for spalling due to salt, is along the inward corners within Wallace sandstone blocks (Plate 16B). This is especially apparent on the north side, however is seen on all sides.

Salt destruction is most apparent at the street level, in local limestone foundation blocks. Spalling leaves shards of limestone on the ground below the blocks that exhibit efflorescence. Fractures in the limestone could be caused by shifting, ice wedging, or salt crystallization. The fractures were probably in the rock originally, opened by frost or salt, and then expanded by lateral shifting along the fractures.

Black soot is only slightly apparent, due to recent cleaning and possibly because of the sheltered nature of the building. Soot has started to accumulate along tool marks, resulting in a distinctive banding. Soot tends to build up in the depressions first, where it is trapped or protected from removal. Slight recessions follow bedding.

\subsection{Daly Building.}

The Daly building was built in 1905 and acquired by the government in 1916 . Formerly the Rea building, the Daly Building was originally only two stories high, but additions from 1913-16 added five floors to the original structure and a seven story, four-bay addition to the north. The building was a massive rectangular stone structure with an area of 2,787 square metres, and large, repetitive windows (Chicago 
style). In 1964 a decorative cornice was added to the top of the building.

A consulting report was commissioned in 1990 by the National Capital Commission to Suter/Keller Engineers in which engineering, geological and architectural reports were included. Data from the unpublished geological report (Donaldson and Munro, 1990) provided observations and interpretations that have been built upon in this thesis.

Two stone types were used in the construction: a locally quarried (probably at the building site) limestone, and a second locally quarried limestone for the 1913 additions. The first stone is considered to be from the Cobourg Formation of Trenton Age (Donaldson and Munro, 1990). Samples of this type, termed type I, are a buff-grey coloured lumpy-bedded muddy limestone with silt build-up on the exposed surfaces. The rock is fragmented with numerous stylolites, vertical fractures and fossil fragments. The rock type used for the 1913 addition (type II), is considered to be from the Lowville Formation, also of Ordovician age, but older than Cobourg, and is of a more massive, coarsely crystalline nature. This stone was used as columns and spandrel supports.

Features in these building stones included fragmentation, frost wedging, spalling, and minor dissolution. The type I stone blocks display considerable deterioration. This is due to the fragmented and fractured nature of the stone. Spalling and breakage of facing-stone has been accentuated by the method of construction. Most blocks were tightly spaced, not allowing appropriate expansion of the rock. Plate 17 reveals some of the most distinctive weathering features. Steel pins 
were used to tie back facing stone blocks and the vertical engagement pins had completely rusted, resulting in expansion and spalling of rock fragments. This was most apparent in header stones. Blocks which were most exposed to rain such as sills and column capitals were seriously disintegrated and fractured.

The type II stone, used for the 1913 addition, is an intraclastic coarsely crystalline limestone. This rock has a greater modulus of rupture and is considerably more resistant to weathering.

The former Geological Survey and Mines Branch building, located at the corner of Sussex and George Streets, was built in 1860, originally as the Clarendon Hotel. The stone is similar to type I stone of the Daly building; many blocks near the ground and in sills display continuous fractures, commonly gaping 1-3 mm wide.

\subsection{Notre Dame Cemetery.}

A brief investigation into the weathering of headstones at the Notre Dame cemetery was performed to assess the several types of rock used, in relation to the date of emplacement and the exposure to centre-town pollution.

Grey and white marble headstones have bedding and silicate or pyrite mineralization which, depending on age, stand in relief relative to the calcite. A crude relief determination was performed to roughly calculate the amount of carbonate dissolution. Five measurements were made on each of the four sides (north, east, south, and west) with a digital depth micrometer for three grey marble headstones and three white marble headstones. A computer program was written in 
turbo $\mathrm{C}++$ to calculate the average decay rate $(\mathrm{mm} / \mathrm{year})$ for each side of each headstone, the average of each side for all headstones, and finally the overall decay rate. The algorithm, input, and the results are recorded in Appendix II. Only six headstones were measured, due to the scarcity of sufficiently old headstones that contained enough elevated minerals to measure.

The results indicate that an average of $0.0042 \mathrm{~mm}$ of rock is lost to solution each year. The west face lost the most material $(0.0045 \mathrm{~mm})$ and the north face lost the least $(0.0038 \mathrm{~mm})$. The results are somewhat variable due to differences in composition. The white marbles appear to have lost slightly more material than the grey marbles.

Pure white marbles in the oldest headstones could not be used to obtain relief measurements, due to a lack of non-carbonate minerals. However, these headstones appeared to be the most corroded, and in many cases, the lettering could no longer be read. Most of these pure white marbles had yellow or grey lichen growing on the surface, but no appreciable differences in relief were noted around these lichens.

Brown sandstones were severely corroded, especially in the centres of ornate relief, much like the centres of gables. The smaller the hollowing, the more severe the spalling and crumbling. On flat faces, especially where drainage is constant, black or dark coloration is pronounced. These two features are distinctly linked. Where water is drawn into hollows or under lips, gypsum crystals can build up, block pore entrances and subfloresce. This action breaks up the surface grains and promotes crumbling or spalling. Where water can continuously flow, organics can thrive and 
collect iron, manganese or other dark materials, yet gypsum crystals are removed by water flow and do not precipitate as often. The sooty crust is less likely to be removed by subflorescence. 
Plate 11.

A. Differential weathering in Nepean sandstone. Note that the least resistance is shown by the distinctively laminated blocks.

B. Spalling in Wallace sandstone due to migration of salts to the centre of a block where precipitation takes place (A). 

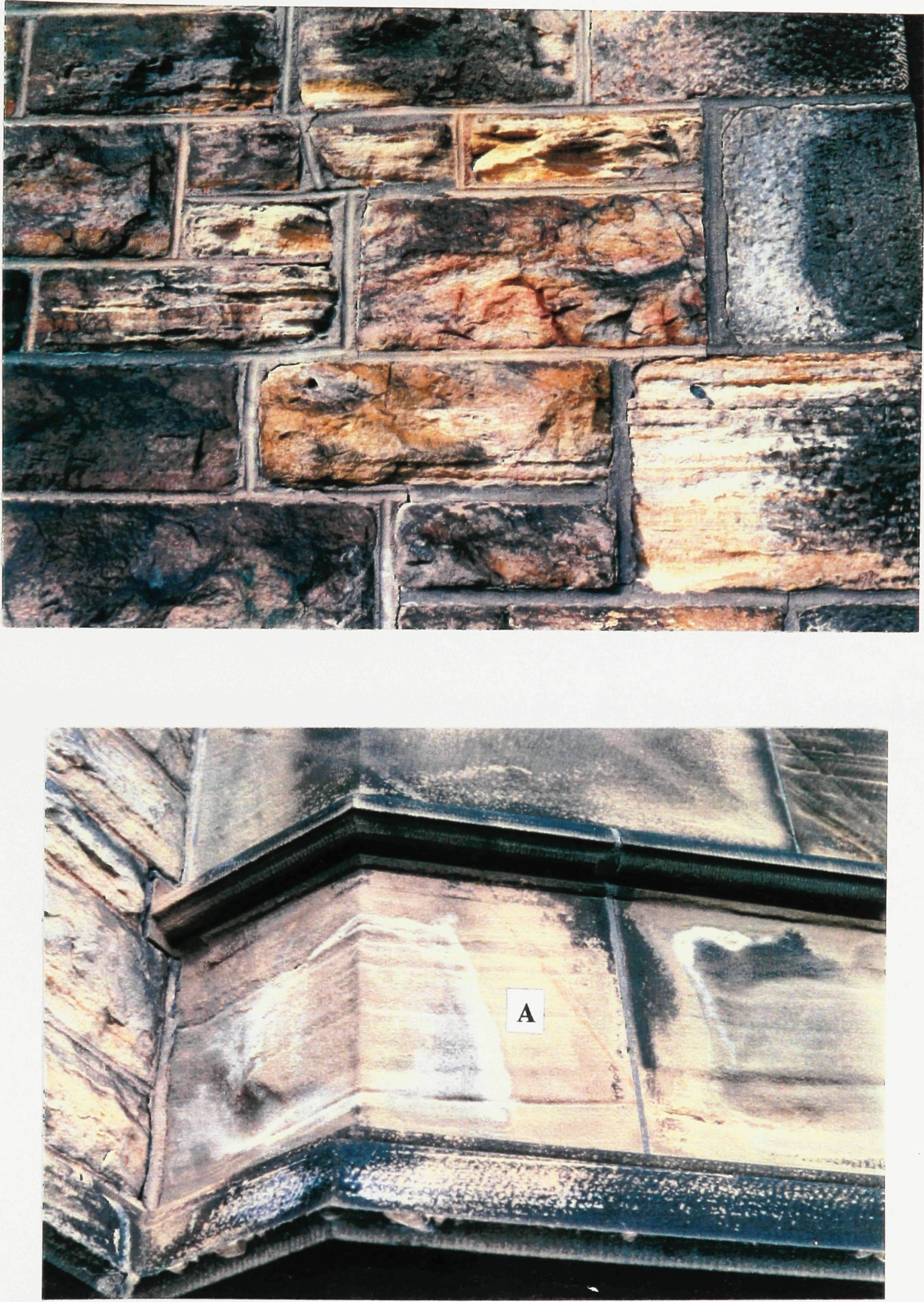
Plate 12.

A. Spalling and surface disintegration in Ohio sandstone $(\mathrm{O})$ due to crystallization of de-icing salts. Note the lower block of Wallace sandstone (W) is markedly more resistant than the Ohio sandstone, which is severely recessed.

B. Mortar capping on spalled surfaces of Wallace and Nepean sandstones; the south face of the Peace Tower, Parliament buildings. 

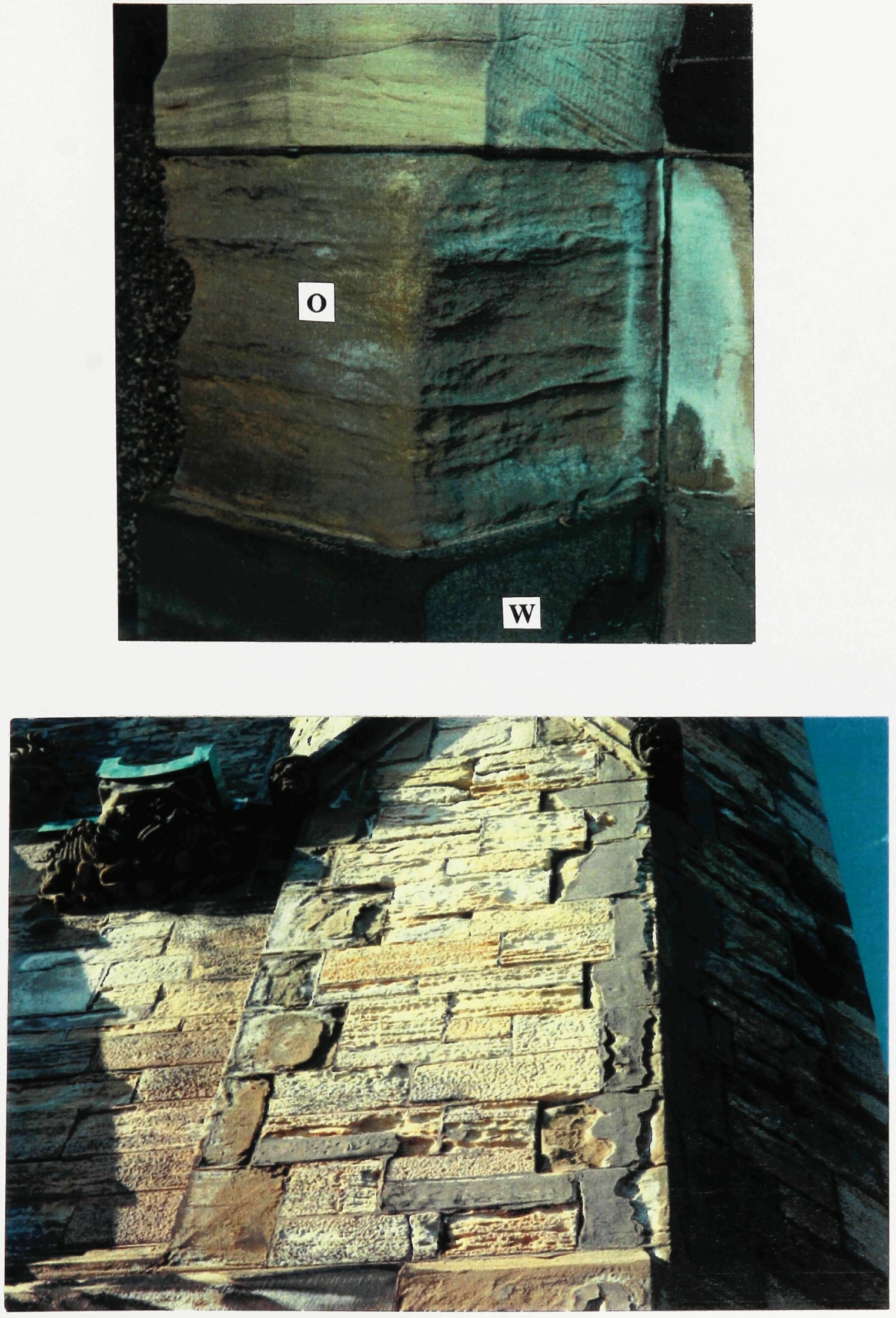
Plate 13.

A. Gypsum scaling in a gable. Protected from flushing rainwater, the central portion of the gable is spalling at a rapid rate.

B. Iron oxide staining and weathering in Hampstead granite, just in front of the Centre Block, Parliament Buildings. The edge of the stone is chipped and recessed, due in part or in whole to iron oxide formation from pyrite and biotite. 

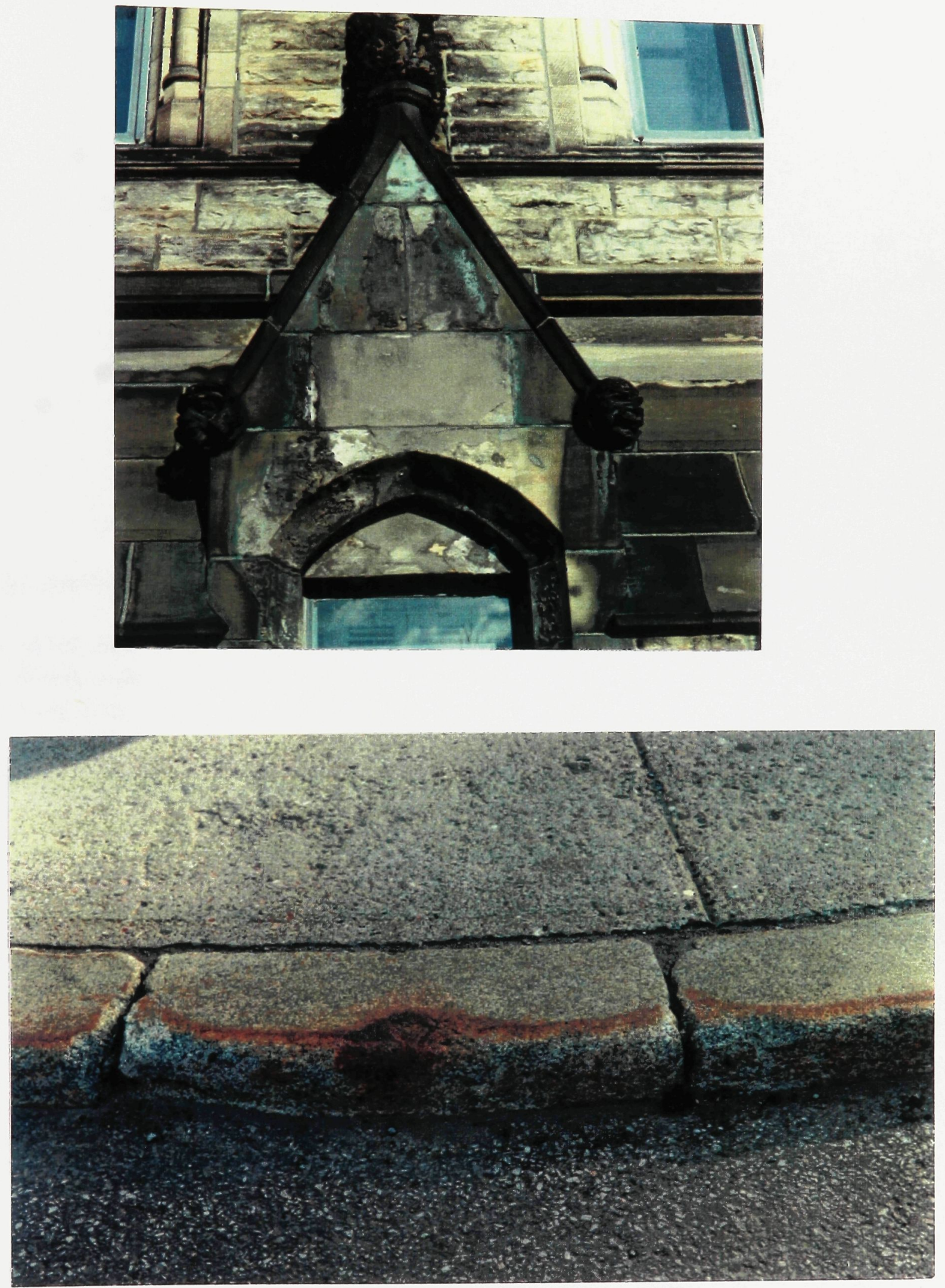
Plate 14.

The southwest entrance, on the south side of Centre Block, Parliament Buildings.
A. West side
B. South side
C. East side

Note the obvious soot build-up on the east face of the entrance. 


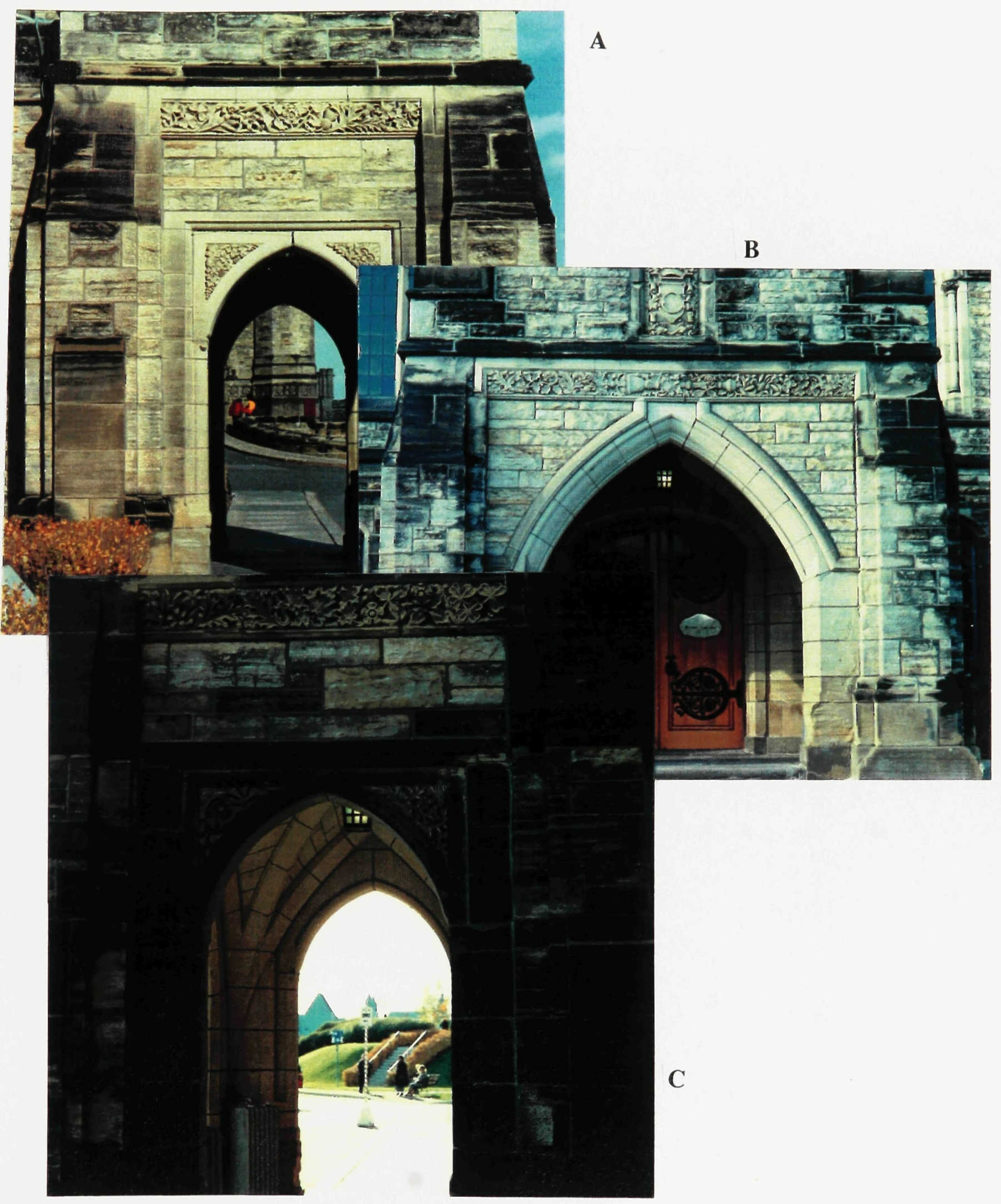


Plate 15.

A. Sooty accumulation on Ohio sandstone. The soot buildup on blocks below the cornice (C) defines the drip line (D) and rain-flushed stone. The lack of soot immediately below the cornice is "clean" due to spalling from accumulating salt crystals. North face of the West Block, Parliament Buildings.

B. Moss and leaf-bearing plants growing in the mortar and Nepean sandstone (M). North side of the Library of Parliament. 

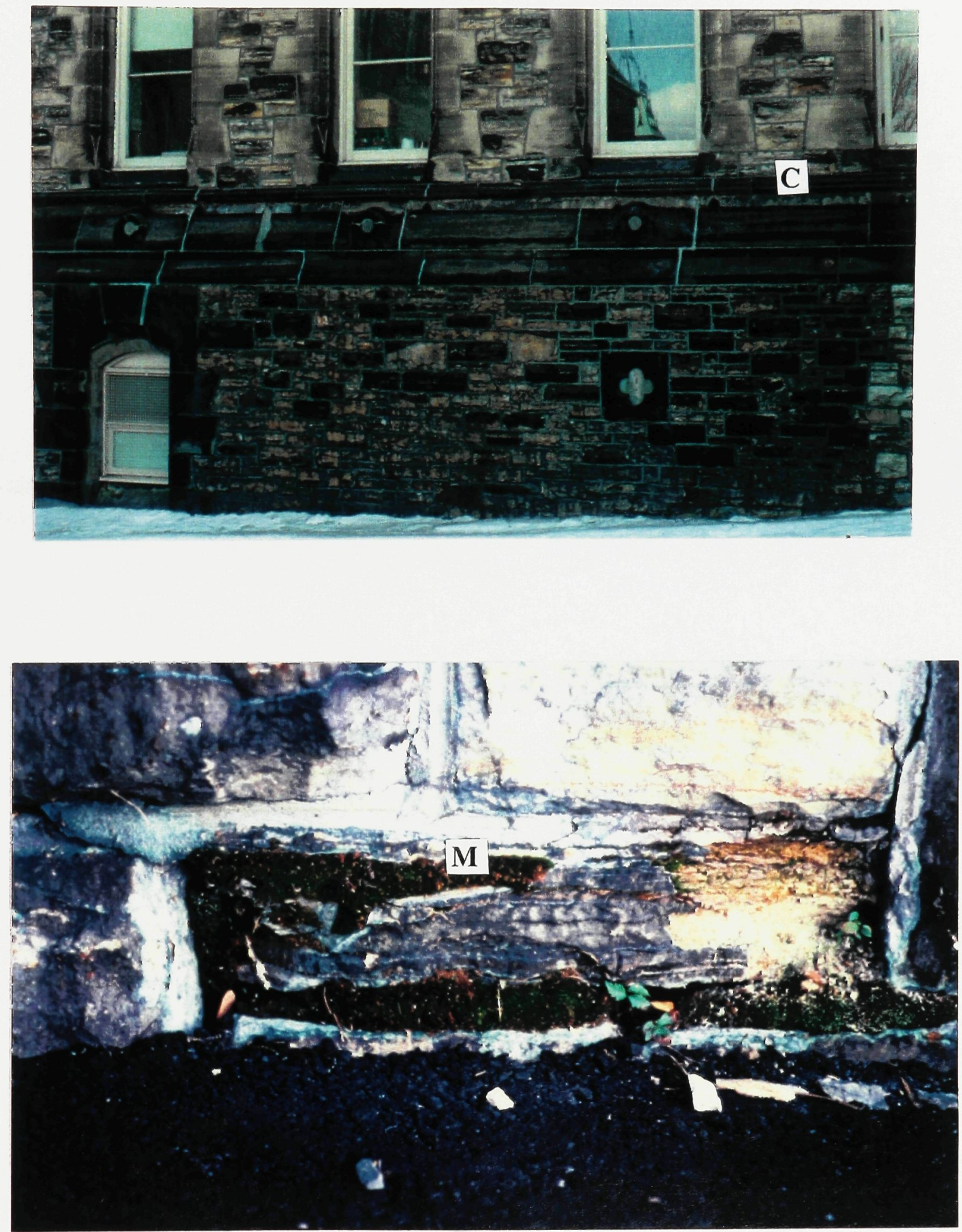
Plate 16.

A. Spalling on only one side Wallace sandstone (W) along the edge of Nepean sandstone $(\mathrm{N})$. This could be due to wind direction and partly due to sunshine direction.

B. Spalling in corners of Wallace sandstone, and efflorescence. 

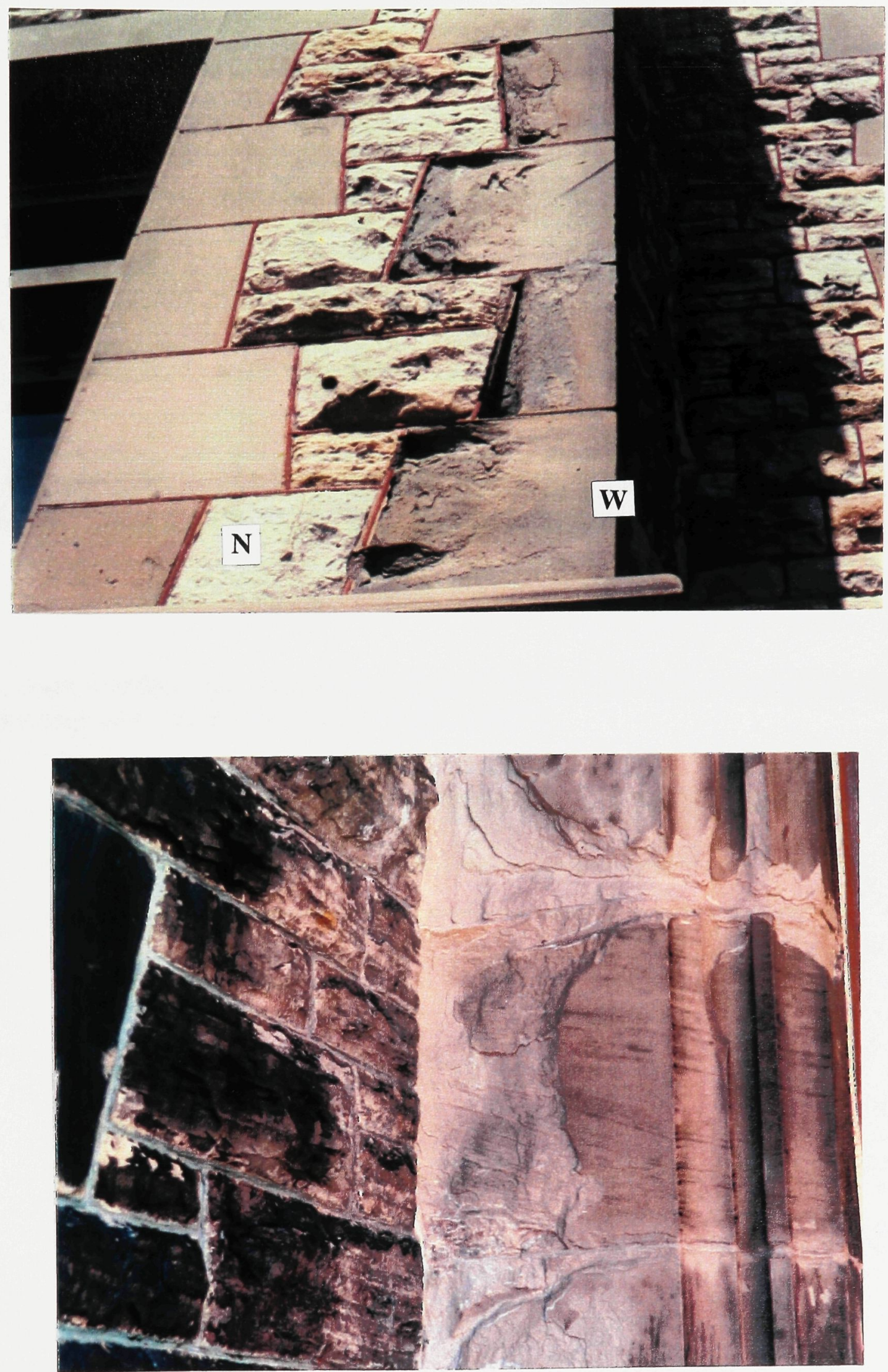
Plate 17.

A. A stylolite (S) in a block of Type II limestone, from a column in the former Daly building. Small vertical fractures (F) can also be seen throughout the rock.

B. Lumpy bedding and extreme weathering seen in Type I (Cobourg) limestone, from a building adjacent to the former Daly building. 

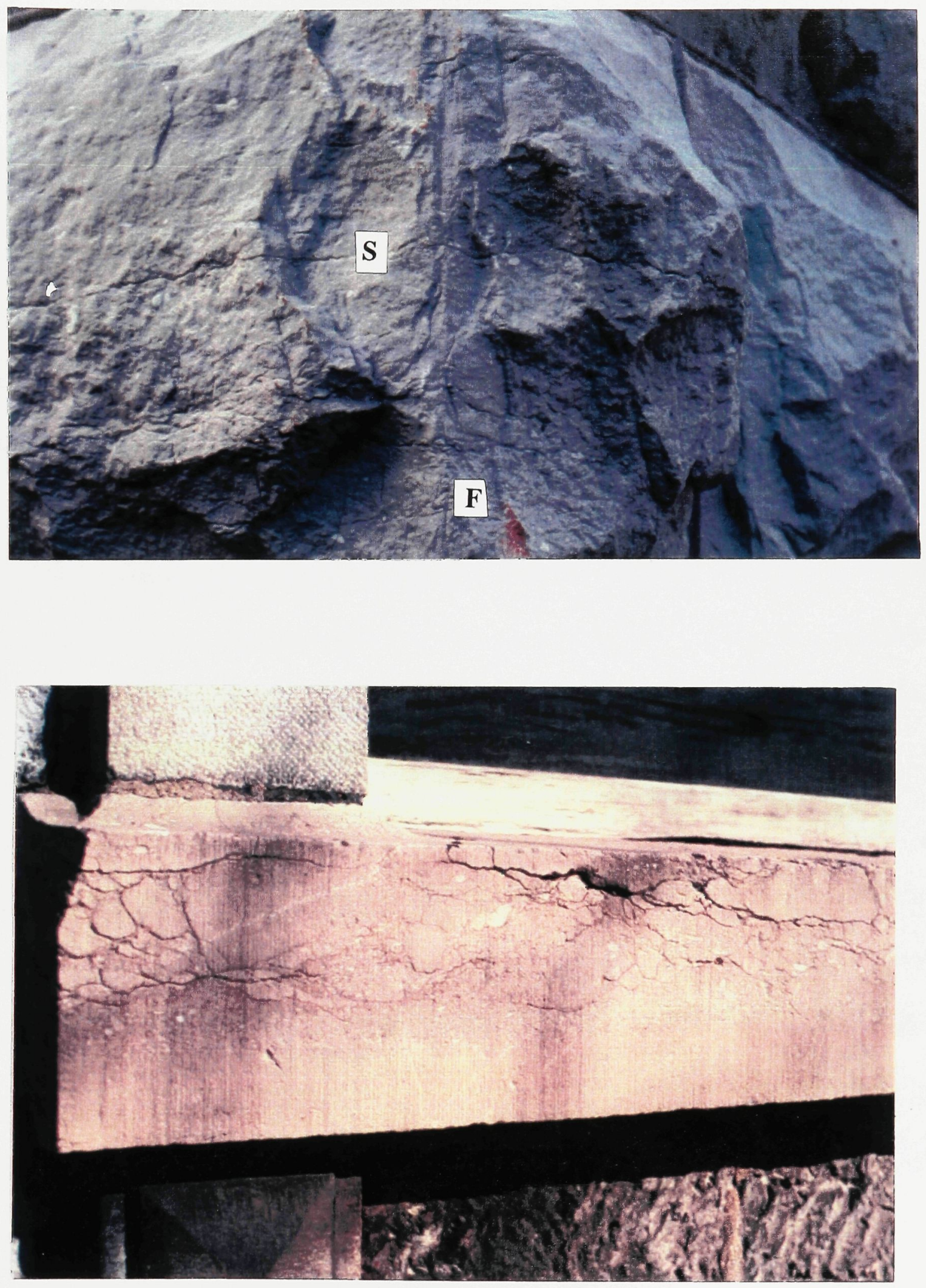
Chapter 6. Discussion of Results

\subsection{Weathering.}

The climate of Ottawa has a direct bearing on weathering characteristics of building stones. Ottawa has a cold climate, with several months of below freezing temperatures and more importantly, many days in which the temperature fluctuates above and below the freezing point. Freezing and thawing has been shown to be extremely detrimental to the cohesion of some porous rocks (Hudec, 1975). Crystal growth produces excessive strain in fine pore spaces and results in rupture.

The levels of pollution at Ottawa can be described as moderate to high relative to other large cities in Canada. Levels of $\mathrm{SO}_{2}$ are quite low, as they would be expected to be in contrast to areas close to industrial and smelting industries. This has not always been the case, however, with a pulp and paper mill nearby and traditional coal burning for furnace fuel. However, the levels of $\mathrm{SO}_{4}$ are anomalously high relative to Montreal and Saskatoon. Perhaps the levels at Toronto, Sudbury, and Windsor would be high as well, but data are not available for comparison. $\mathrm{NO}_{2}$ levels are moderate, corresponding in a general way to the volume of automobile use. A surprising result is the level of $\mathrm{CO}$, which rates higher than Windsor and Montreal, and nearly reaches the level of Toronto. The location of the detector may be a factor. The soiling index is relatively high, and probably relates to the amount of carbon dust from exhausts.

Acidity of rainfall at Ottawa is quite high, nearly at the level considered 
dangerous for lakes. Due to a lack of statistics, it is difficult to compare these or other measures of pollution for changes over the past century.

Absorption tests indicate the approximate amounts of water that will be incorporated by a rock over an extended period of time. The results show distinct differences for each rock type, and within some of the rock types. Sandstone varies greatly, as does limestone, and generally indicates a porous material. All other samples have very low porosity, including the local limestone. Specific gravities show trends opposite to the absorption trends, reflecting the abundance of pore space as well as mass differences of constituent minerals.

Numerous publications have demonstrated the influence of pore size on the destructive mechanics of ice formation. Rocks which predominantly have pores greater than 3um are relatively resistant to rupture. Large pores are easier to drain, leaving space for ice crystals to expand. Rocks with predominantly small pores (<3um) rupture more easily. Within these pore spaces, thin films of adsorbed water produce greater hydroscopic pressures than ice within the pores. Consequently, the adsorbed water attempts to migrate to areas of lower pressure at the surface, in order to crystallize as ice. If the water is blocked or if the water moves too quickly, corresponding to a rapid drop in temperature, the liquid becomes unstable and rupture will take place.

This scenario becomes slightly more complex with salt water. During cooling, the solution remains as a liquid longer because of the lower freezing point associated with salt. A saturated salt solution $(\mathrm{NaCl}, 26 \%)$ will begin to freeze at $-22^{\circ} \mathrm{C}$. A weak 
salt solution will begin to freeze sooner, concentrating the remaining solution. Rocks immersed in $3-5 \% \mathrm{NaCl}$ solutions show the greatest amount of expansion and failure. With lower concentrations of salt in the water, a large proportion of the solution will freeze as it reaches the surface of the rock, and this will block the pores, reducing the rate and amount of water migration. A significant finding from expansion tests by Litvan (1975) indicate that expansion continues below $-25^{\circ} \mathrm{C}$ with all saline solutions, but not with pure water. It is possible that the porosity is more significant than the pore size with salt crystallization. Salts, especially $\mathrm{NaCl}$ and gypsum, can build up within pores where moisture levels are high but flow is impeded. This, together with repeated freezing cycles, can result in ever-constricting pores. These concepts are consistent with the experiments, and with the weathering features seen in the rocks that were studied.

Nepean sandstone displays a wide range of weathering features and weathering intensity. Those portions of the sandstone that are more porous tend to recess selectively and effloresce within these pockets. The impervious siliceous beds project with greater resistance. This can also be caused by chemical leaching of carbonate cement, destroying cohesion. Although the freeze/thaw and wet/dry tests did not suggest that severe damage would be expected, the sample studied probably differs from many others due to the heterogeneous nature of the rock. All that can be concluded is that some portions of the Nepean sandstone, (the less porous, silicious forms) are resistant to weathering. Pore size determinations show that the sample analyzed has mainly large pores and should not be considered highly 
vulnerable to frost damage.

Wallace sandstone demonstrates spalling, especially at outer corners where water can infiltrate from two sides and wind can accelerate drying. Drying in turn promotes efflorescence. Most pore sizes are large, but the distribution is greater than in the Nepean sandstone, and thus could render the Wallace sandstone more vulnerable to frost action.

Ohio sandstone is drastically weathered by salt formation. This is best shown with the lower blocks in the entry arches. Wallace sandstone draws water up the sides, but the overlying Ohio sandstone soaks in salt like a sponge, and retains this salt for long periods. Pore sizes are similar to the Nepean, mostly very large with very few in the fine range. In the absence of salt, Ohio sandstone should be more resistant than Wallace to frost action.

Indiana limestone tends to weather chemically due to its carbonate-rich composition. Little damage due to mechanical weathering was seen in this rock type in buildings, possibly because chemical weathering masks the mechanical weathering. The freeze/thaw and wet/dry experiments revealed, however, that this rock type is the most vulnerable of all types tested, losing $.021 \%$ and $.037 \%$ mass in the respective tests. Since the tests were not conducted the same way, they should not be compared to each other directly. The freeze/thaw results correlate well with the pore size distribution results, which indicate a large number of pores in the fine range. The wet/dry results are an indication of weathering over a long period of time, but may reflect artificially induced accelerated weathering due to the use of a brush to remove 
loose material. Indiana limestone displays a propensity for fast mechanical weathering in the presence of saline water, with or without freezing. Most pores are spread between 55 and .117 microns, suggesting that Indiana limestone would be susceptible to both frost and salt.

Local limestone (Cobourg Formation) collected from the Daly building exhibited very low absorption. This was confirmed by the porosimeter data, which assigned $1.7 \%$ porosity to the stone. The droplet test showed that the rate of absorption was slow, but the deviation in results was significant, just over half the value. This is accounted for by the interconnecting fractures that mostly follow bedding and stylolites. Water could be seen channelling along fractures as it was being absorbed. This was a fresh interior sample, yet many of the weathered outer surfaces are far more fractured. Pore sizes were variable, and may indicate fracturing or vugs. Most pores were large. Most large fractures in the Daly limestone outline lumpy bedding, and therefore interconnect. This leads to deep wedging and hence dislodgement. Stylolites are plentiful and allow for movement between the two sides along the slick clay-coated surfaces, causing significant displacement in the Daly building. The high degree of water movement allowed for an open system and advanced chemical weathering. The samples used in the freeze/thaw and wet/dry tests developed a thin surficial coat of beige dust, similar to that seen on weathered faces of in-situ building blocks.

The igneous rocks show much lower absorption than the sandstones, but there was a surprising loss from the granites in the freeze/thaw and wet/dry tests. Possibly 
salt corroded the magnetite and biotite sufficiently to generate such a loss. In the Rapakivi granite, the corrosion of magnetite was obvious, resulting in pits on polished faces. The mafic igneous rocks did the best in the tests, losing only an insignificant mass. These rocks would however, succumb to chemical weathering over time.

Figure 24 illustrates the relationships between the rock characteristics and the amount of mass loss in the weathering tests. The data for each property were modified by the following factors to demonstrate their relationships on one graph:

$\begin{array}{ll}\text { absorption... } & \mathrm{X} * 50 \\ \text { specific gravity... } & \mathrm{X} * 1 \\ \text { porosity... } & \mathrm{X} / 4 \\ \text { droplet test... } & \mathrm{Log}\{1+(1 / \mathrm{X})\} \\ \text { freeze/thaw... } & \mathrm{X} * 100 \\ \text { wet/dry... } & \mathrm{X} * 100\end{array}$

The modification to the droplet test caused an inversion which relates directly to porosity and absorption rather than to the length of time for absorption. Note the overall trend that signifies a correlation between porosity/absorption and degree of weathering. Notice however, that the greatest loss was for Indiana limestone, which does not correspond to the peak of the absorption, porosity, or droplet test curves. This is due to the pore size distribution. Indiana limestone consists of fine pores which are easily blocked, resulting in excessive pressure as water attempts to migrate 
to the surface, and salt crystals grow within the confined pores.

A second graph was developed to illustrate the effect of pore size and absorption with the amount of spalling in the experiments. Figure 25 plots absorption and spalling against the most abundant pore size for each sample. This illustrates the influence of fine pores on deterioration. Note the greatest loss was with the Indiana limestone, which has a majority of pores that average $0.35 \mathrm{~mm}$.

Scanning electron microscopy revealed that the thin black coatings on sandstone are composed mainly of colloidal iron with patches of carbon. The carbon accounts for the black coloration, and probably comes from vehicle and industrial exhausts. Some of the stone blocks have not been cleaned for several decades, and thus coal and wood burning in the past could account for much of the carbon. The colloidal habit of the iron suggests a biological source, much like the reported "desert varnish", and several strands of probable biogenic origin were observed on the surface of the rock. Furthermore, the greatest concentrations of black surface coatings are close to the ground where water flow and retention is greatest, providing a habitat for organisms.

The surfaces of Ohio sandstone are particularly coated with black veneer, probably in response to moisture content. Where surfaces of this and other vulnerable rocks were clean, gypsum crystals commonly occur between the clean and blackened surfaces. Gypsum crystals had formed as a subflorescence that pried the outer blackened crust off. Where the blackened surface remains for long periods, it 


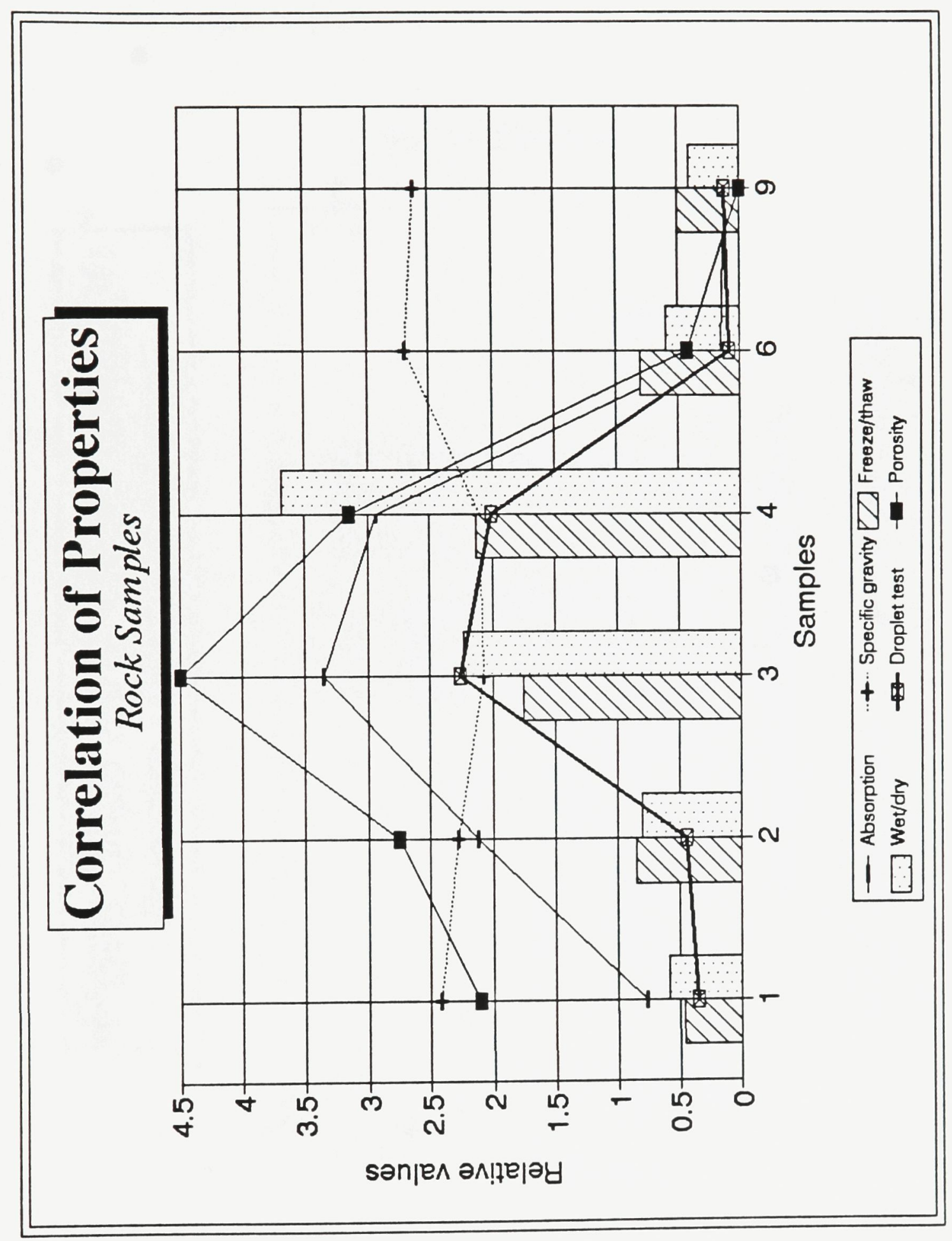

ก)

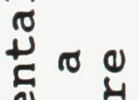

อ 조

4)

억 ?

x.

1) - $>+$

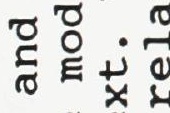

(1) 0

(1) क्षे

•

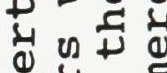

잉 ट

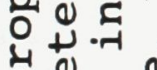

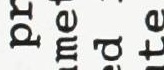

ส

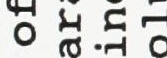

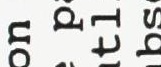

○

$+$

का मे

400

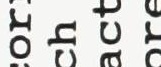

0 U

« ᄃㄷㅇ

- Uु.न

$\sim$

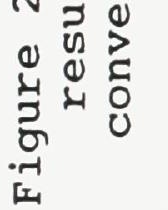


(\%) uo!̣dıosq
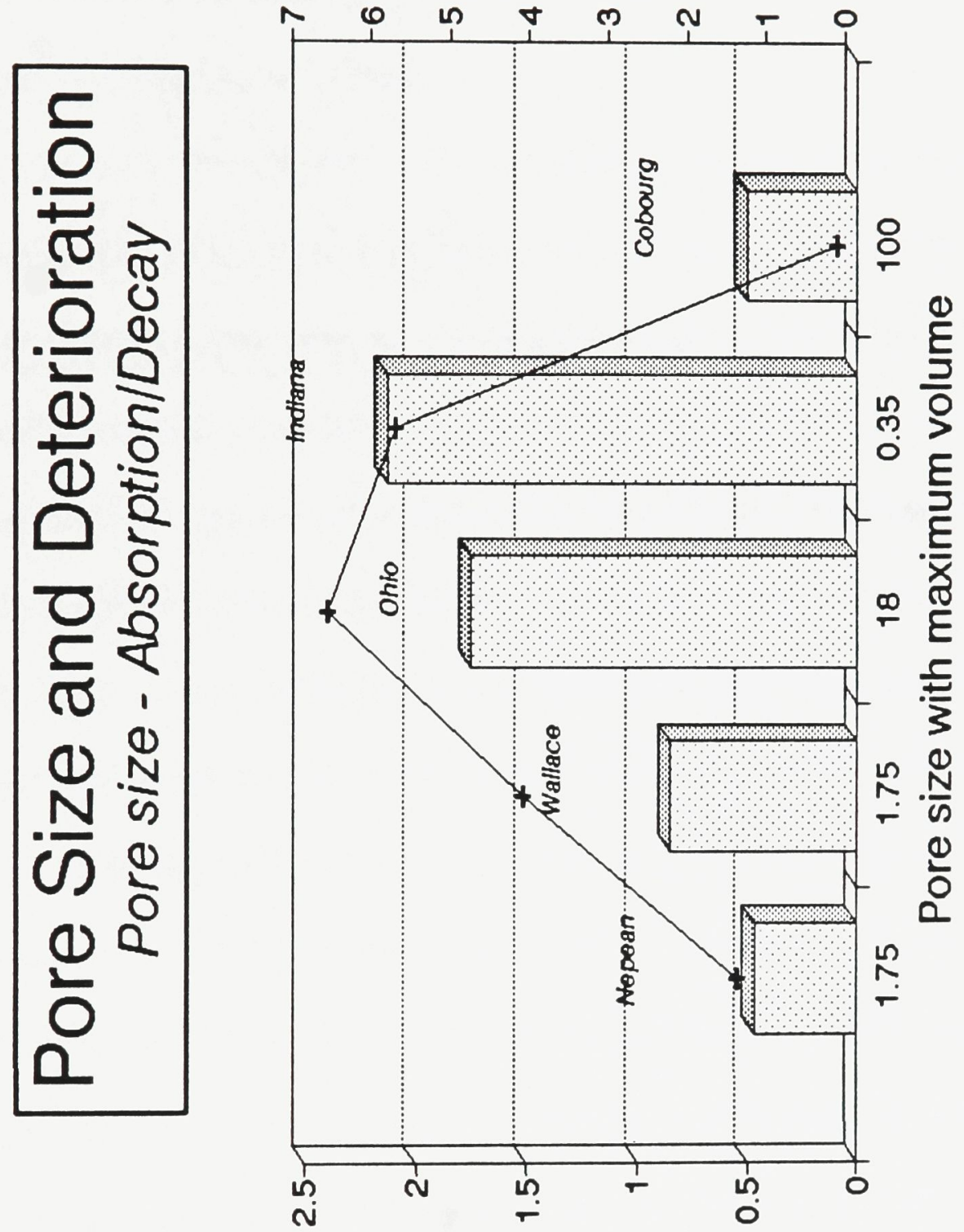

(\%) ssol MEчұ/əzəəג」

ᄃ.

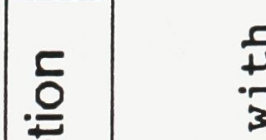

임

$\rightarrow 0$

ช. N

虰

(1)

다 잉

$+2$

ट

洁

-न

40

을

(1)

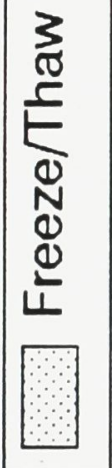

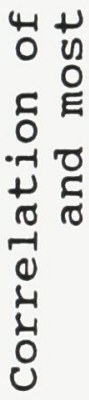

$\stackrel{n}{\sim}$

己ู 
is likely that internal damage is accelerated due to the containment of moisture.

Iron oxide commonly develops on the surface of Nepean sandstone due to the destruction of pyrite. Obvious destruction by iron oxides also is exhibited by the granite sidewalk in front of Parliament in which rusty bands develop just behind surfaces of spalling and chipping.

Chemical weathering is most noticeable in some of the Nepean sandstone and the carbonate rocks. Beds and lenses rich in calcareous cement are sunken due in part to porosity, but also to the abundance of calcite that leaches out. Indiana limestone exposes weathered fossils on the bannister at the northwest side of the library, and carvings are smoothed and reduced at their edges due to dissolution. The acidity of rainfall and fog accelerates this process. The rate at which dissolution has taken place is approximated to be $0.0042 \mathrm{~mm} / \mathrm{year}$ from relief measurements on marble headstones at the Notre Dame Cemetery, but the rate may now be altered due to changing pollution levels. In the past twenty years, most pollutants have decreased in intensity; however, the increase in vehicle emissions and the decrease in industrial emissions could alter the weathering process by changing the nature of rainfall, and this could change the rate of weathering. The interactions between sulphur, nitrogen, and carbon with water are not clearly known, and so modelling changes in weathering would be difficult. From the headstone data, the west face of headstones is affected most by dissolution, averaging $0.0045 \mathrm{~mm} / \mathrm{year}$. The north side shows the least amount of weathering. This probably is due to prevailing winds driving moisture in one predominant direction. A study involving more headstones 
and several cemetaries could serve to confirm these observations.

The three buildings studied all show significant signs of weathering. The most detrimental effect is caused by salt water acting on sandstone blocks in the Parliament buildings. Salt has also caused deterioration of the Victoria Museum and Daly buildings, but other factors can be even more detrimental. The Victoria Museum is especially prone to effects of wet/dry mechanisms as well as salt. The Nepean sandstone blocks show differential weathering between and within each block. Wallace sandstone shows spalling associated with frost and drying cycles. As for Parliament, edge blocks consistently spall more on the damp side. Gypsum crystals will crystallize where moisture persists and flow is restricted, as in hollows or depressions and in the centres of rock faces. Gables are particularly susceptible, and show profuse scaling.

Attempts to control spalling by capping a disintegrating face with mortar only serves to accelerate weathering. Water which seeps into the rock from above, or along joints, migrates to the surface and contacts the carbonate-rich mortar. Being trapped from the drying sun and wind, chemical reactions between the mortar and water produce gypsum and carbonic acid. The acid corrodes the calcite cement in the Nepean sandstone, and gypsum will crystallize and expand.

\subsection{Replacement stone.}

The core of three drill holes were logged to evaluate the potential of Ottawa limestone and Nepean sandstone for replacement material. Two drill holes are in 
Nepean sandstone and the third is in Ottawa limestone. The logs and sections are shown in Appendix III.

From examination of the Ottawa limestone, no clear intervals of dependable building stone were seen. Most horizons are intercalated with shale beds, and they show abundant stylolites and fractures. Some units could be used, and if a section was to be exploited, surface extensions of the intervals from $520 \mathrm{ft}$. to $753 \mathrm{ft}$. (the Hull, Rockland, Leray, and Lowville Formations) in the Billings Bridge Hole would be the best intervals. Areas in southern Ontario have much better limestone quarries with fewer structural flaws.

The Nepean sandstone is no longer quarried in Ottawa or anywhere else in Ontario. The old quarry at Bells Corners is held by CANMET in case additional blocks of stone are needed. The quarry is approximately 15000 square metres in area and only $5 \mathrm{~m}$ deep. The quarry is near the top of the Nepean Formation, because the overlying March Formation outcrops near the main road, and because a great deal of iron-oxide and porous lenses occur here.

Several sedimentary structures are evident in the quarry. Ripples are common on the floor of levels one and two (see the airphoto in Appendix V). Dewatering structures were seen at the north end of the quarry and on level 2. Desiccation cracks and possible burrows were seen infrequently at the north end of level 1. Liesegang banding is common on the second level, south side, and along the second level face. On both level floors, scattered depressions are left where calcite has been dissolved. Channels are apparent in both the north face, level 1, and the east face, level 2. Most 
of the rock is highly siliceous, silica-cemented, and in beds at least $10 \mathrm{~cm}$ thick. Elsewhere the beds range from $10 \mathrm{~cm}$ to $<1 \mathrm{~cm}$. At the east face, level 2 near a channel, a series of fractures trends $200^{\circ}$. The surface expression is a series of parallel ridges. The faces of the fractures are flat and smooth, dipping $80^{\circ}$ north. A large block of stone near the northeast face of level 2 (quarry source unknown) contained a $1 \mathrm{~cm}$ gap infilled with crumbling pyrite. Beds in the quarry that are most suitable for building stone are between $0.6 \mathrm{~m}$ and $2.7 \mathrm{~m}$ up from the floor of level 1 . This rock is buff to white, thickly bedded, lacks significant pyrite, and is mainly siliceous. Possibly some of the fractures are faults, and therefore more detailed mapping would be necessary before large quantities of stone could be properly quarried.

According to the logs, the section from about $13.7 \mathrm{~m}-27.4 \mathrm{~m}$ above the Precambrian contact is the most unblemished stone for building purposes. Choosing a stone based on colour is not appropriate, because iron-stained blocks could prove to be poor quality structural stone. If a horizon is exploited for colour or banding, weathering features should be expected to appear sooner and be more destructive than in the more siliceous, massive stone. From the log at Lanark, it is apparent that lower portions of the Nepean Formation are near surface, and could probably be quarried.

\subsection{Preservation.}

Preservation techniques involve either chemical modification or chemical impregnation (Bell and Coulthard, 1990). Chemical modification of a stone can 
change the manner in which the rock interacts with the environment, consequently altering the chemical reactions and preventing the production of harmful salts. An example is the alteration of marble and limestone by adding $\mathrm{BaCl}_{2}$ and $\mathrm{Ba}(\mathrm{OH})_{5}$ solutions, forming $\mathrm{BaCO}_{3}$ which is less soluble than calcium carbonate. Chemical impregnation acts to prohibit water entry and to secure loose material. In the past, waxes, linseed oil and metallic stearates have been used with poor results, either due to a change in stone appearance or the formation of acids. Silicones, divided into classes for sandstone (class A) and carbonates (class B), have been more recently used, however obtain poor penetration for medium porosity rocks. A third class, C, is called siliconates and is primarily meant for carbonates because it tends to cause rust staining in sandstones that contain ferruginous material. Penetration is poor and are ineffective upon retreatment. The thin skin created by these silicone treatments permits salts to crystallize near the surface and cause spalling. Silicone treatments are short-lived and must be applied every few years.

A technique was used on the lower outer walls of the East and West Blocks of Parliament, in which a resin was applied to the rock faces. The results of weathering cannot be determined, because no samples could be attained, and both the application date and substance used are unknown. However, the resin has turned a dull orange colour. This could be the result of sunlight on the resin, or perhaps the outward migration of iron oxide that has been trapped behind the resin surface.

Another technique applies isobutyl monomeric alkyl alkoxy silane, a combination of organic and inorganic molecules, which attaches one side of the 
molecule chemically to a silicate grain, and the other side, which is hydrophobic, disperses water yet allows the pores to breathe (Attewell and Taylor, 1990). Unfortunately this techniqe is very expensive.

It is difficult to evaluate such preservatives, because most applications are relatively new and untested through time. The buildings in Ottawa could have impervious barriers installed at their bases, to slow the upward absorption of salt water. More sand could be mixed with salt for application to roads near stone buildings in winter. Salt boxes should be bottom sealed and moved away from the buildings. Any preservatives used on the stone should first be tested on site to determine changes to the stones appearance. 


\section{Chapter 7. Conclusion}

The buildings in Ottawa demonstrate significant weathering features as a result of the climate, pollution, de-icing salts, architecture, and biological activity. The combination of these weathering agents and the properties of the rocks, determine the type of weathering, rate of weathering and the features that result from weathering. Some blocks can weather more than others by mass and yet be sounder. Other rocks can appear to be more resistant due to low porosity and low mass loss, and yet be easily weakened structurally. This was the case for Ottawa limestone in the Daly building. The style of weathering and the features in the rock contributed to the failure of performance.

Some building stones display a variety of features due to wide variations within the rock. This is especially true for Nepean sandstone, in which sedimentary structures and bedding variations result in differential weathering, and discolouration is a result of oxidized pyrite.

Other rock types are considerably more uniform in structure and composition. Wallace sandstone has a uniform structure and moderately high porosity. The features most commonly seen are spalling associated with salt or frost action. Ohio sandstone is very porous, generally uniform, and has large pores. Ohio is vulnerable to salt weathering, a feature dramatically displayed in lower entry-way arches which have been reduced significantly in size.

The Peace tower is expected to be completely repointed and all cracks infilled 
over the next two or three years. Gypsum has formed as a result of water interaction with the concrete backing. The water migrates to the surface of the stone and precipitates gypsum crystals as sub- and efflorescence, removing the outer layer of stone. A softer, more plastic mortar will be used between the stone blocks to allow for expansion and contraction; it is better to crack the mortar than the stone.

Indiana limestone is easily attacked by solution, and because it is characterized by small pores, it is vulnerable to frost action, especially in the presence of salt. Dissolution is difficult to monitor, however on the Chateau Laurier, a rough surface indicates fossills are weathering at a slightly different rate and dissolution is occurring. Most of the Chateau Lauier and other limestone buildings have a one metre base of granite, which hinders the absorption of salty water from the ground. At entrances, the action of salt is evident, as efflorescence is common, and spalling serious.

Hampstead granite contains large crystals of pyrite which rapidly oxidize. Biotite provides an additional source of iron; walkways of such granite commonly show water marks that record migrating rust stains. The granite tends to chip along the exposed edge to the side of the rust stain.

The mafic igneous rocks performed best in weathering experiments, and could be considered the most resistant building stone of those studied. However, the experiments do not necessarily record chemical alterations, which should be a significant factor over time in basic rocks.

An average weathering rate of $0.0042 \mathrm{~mm} / \mathrm{year}$ was concluded for marbles in 
Ottawa under urban conditions. This compares favourably with the average weathering rate of $0.0065 \mathrm{~mm} /$ year for exposed marble headstones at Esh, England. If the weathering rate measurements are accurate, orientation is a significant factor in weathering. The west face shows the most weathering and the north face the least. Under these circumstances, it is reasonable to recommend that the wide face be oriented north-south. Treatment of marble headstones, could be effective with a water repellent. Attwell and Taylor (1990) recommend a deeply penetrating monomer with water repellent properties could be used on clean surfaces. Isobutyl silane would allow the rock to breathe and yet would repell water.

Tools such as absorption and pore size distribution are suitable techniques for predicting the weathering performance of building stone, however, these should be performed in conjunction with observational applications such as thin section examination. Knowledge of absorption or porosity should be accompanied by the distribution of pore sizes and visual interpretations of mineralogy, texture, and structure in order to understand how the rock will interact with water, salt, wind, and pollution. The droplet test was a quick and useful test for determining the initial rate of water absorption. The test also indicates variations within a rock which could be used to distinguish between appropriate and unsuitable stratigraphic horizons for replacement stone.

In order to reduce the rate of weathering for sandstone blocks in the Parliament buildings, mortar facings should be removed, and old, hard mortar in joints should be repointed. Any blocks of limestone that were used for replacement 
above sandstone blocks should also be removed. These sources of lime result in the formation of gypsum crystals and accelerate weathering.

Highly absorbant sandstone blocks should not be used near the ground, especially where de-icing salts are regularly used. Lower blocks on the buildings should, when necessary, be replaced with granite, thereby obstructing the ascent of saline water. Since salt acts in a cummulative way, flushing the lower blocks, cornice undersides, and hollows, at regular intervals would help remove the build-up of salt crystals. Where parts of the building jut out, impervious blocks are a reasonable material to use which will limit the amount of absorption and moisture movement associated with wind.

The average block size at the Parliament Buildings is about $0.06 \mathrm{~m}^{3}$ for Nepean sandstone, and about $.014 \mathrm{~m}^{3}$ for Ohio and Wallace sandstones, however the sizes are highly variable. With an average thickness of about $20 \mathrm{~cm}$, these blocks should reasonably last several centuries; exactly how long depends on the structural integrity as much as loss in thickness. The Ohio sandstone blocks at entrances will need to be replaced within the next few decades due to spalling from salt crystallization. Research into the cumulative effects of weathering and internal alteration would be constructive in modelling the lifespan of these rock types.

Replacement for Nepean sandstone can be found in the CANMET quarry at Bells Corners. Good bedded samples were noticed on the east wall of the lower (first) level between $0.6 \mathrm{~m}$ and $2.75 \mathrm{~m}$. Highly silicious material and some good, white bedded stone was seen on the east face of the upper (second) level. It is probably 
necessary to inspect each block for carbonate pockets and porosity. The best material however, is found near the bottom of the Formation and would have to be extracted where the lower part of the Formation is near surface. This would necessitate a quarry near Lanark or another bottom-formation area.

Replacement blocks for limestone buildings should be crystalline, massive, and contain as few stylolites as possible. These requirements are not easily met from Ottawa sources, but reasonable specimens can be found between $158.5 \mathrm{~m}\left(520^{\prime}\right)$ and 215m (705') in the Billings-Bridge drill hole; portions that contain stylolites should be discarded. This corresponds to the Hull through to the Lowville Formations, a section $30.5 m\left(100^{\prime}\right)-73 m\left(240^{\prime}\right)$ below the Billings Formation. From the core, it would appear that some suitable rock could be obtained at the bottom of the Cobourg Formation, however due to the association with the upper portion of the formation, it would probably be wise to avoid any Cobourg material unless thoroughly tested first.

The Droplet test is a quick and reliable assessment of the absorptive properties of a rock and the variability of absorption. It is possible that this method could become an American Standard and Testing Method. 


\section{References}

American Standards and Testing Methods (ASTM).

1986: Standards, part C 97.

Attewell, P., Taylor, D.

1990: Time dependant atmospheric degredation of building stone in a

polluting environment; Environment, Geology and Water Sciences, V. 16, No. 1, p. 43-55.

Ballantyne, C., Black, N., Finlay, D.

1989: Enhanced boulder weathering under late-lying snow-patches; Earth

Surface Processes and Landforms, V. 14, p. 745-750.

Bell, F., Coulthard, J.

1990: Environment, Geology and Water Sciences, V. 16, No. 1, p. 75-81.

Climatic Perspectives.

1993: Acid Rain section; Climatic Perspectives, Vol. 15, August 23-29, P. 5.

Cooke, C., Smalley, I.

1968: Salt weathering in deserts; Nature, Vol. 220, p. 1226-1227

Cooks, J., Otto, E.

1990: The weathering effects of the lichen Lecidea Aff. Sarcogynoides

(Koerb.) on Magaliesberg quartzite; Earth Surface Processes and Landforms, V. 15, p. 491-500.

Dennen, W., Anderson, P.

1962: Chemical changes in incipient rock weathering; Geological Society of America Bulletin, Vol. 73, p. 375-384.

Donaldson, J.A., Munro, I.

1990: Geological assessment of building stone in the Daly Building, Ottawa, Ontario; Unpublished report to Suter Keller Inc., 17 p. 
Dorn, R.

1989: A comment on 'a note on the characteristics and possible origins of desert varnishes from southeast Morocco' by Drs. Smith and Whalley; Earth Surface Processes and Landforms, V. 14, p. 167-170.

Dorn, R.

1990: Rock varnish; American Scientist, V. 79, p. 542-553.

Dragovich, D.

1987: Measuring stone weathering in cities: Surface reduction on marble monuments; Environment, Geology and Water Sciences, V. 9, No. 3, p. 139141.

Drzal, M., Smyk, B.

1968: The role of the micro-biological element in the formation of structures and forms of a rocky substratum;

Przeglad Geographiczny, Vol. XL, No. 2, p. 425-430.

Dunn, J., Hudec, P.

1966: Water, clay and rock soundness; Ohio Journal of Science, Vol. 66, No.

2, p. $153-167$.

Environment Canada

1993: Environment Canada, Monthly Meteorological Summary; Ottawa, July, 1993.

Environment Canada.

1993: Annual Meteorological Summary, 1992.

Environment Canada.

1993: National Air Pollution Surveillance (NAPS), annual summary for 1991;

Environmental Protection Series, EPS 7/AP/24. 
Fagerlund, G.

1975: Studies of the destruction mechanism at freezing of porous materials; Unknown source.

Gauri, K.

1990: Decay and preservation of stone in modern environments;

Environment, Geology and Water Sciences, V. 15, No. 1, p. 45-54.

Goosens, D., Philippaerts, J., Gijbels, R., Pijpers, A., Van Tendeloo, S., Althaus, E. 1989: A SIMS, XPS, SEM, TEM, and FTIR study of feldspar surfaces after reacting with acid solutions; Water-Rock Interaction,

Grant, W.

1969: Abrasion $\mathrm{pH}$, an index of chemical weathering; Clays and Clay Minerals, Vol. 17, No. 3, p. 151-155.

Griggs, D.

1936: The factor of fatigue in rock exfoliation; Journal of Geology, 44, p. 781796.

Hockman, A., Kessler, D.

1950: Thermal and moisture expansion studies of some domestic granites; U.S.

National Bureau of Standards, Research Paper 2087, Vol. 44, p. 395-410.

Hudec, P.,

1975: Correlation of rock weathering parameters; Vleme Congr. Int. F.F.E.N.

Hudec, P., Sitar, N.

1975: Effect of water sorption on carbonate rock expansivity; Canadian Geotechnical Journal, V. 12, p. 179-186.

Hutchinson, A., Johnson, J., Thompson, G., Wood, G., Sage, P., Cooke, M.

1993: Stone degradation due to wet deposition of pollutants;

Corrosion Science, Vol. 34, No. 11, p. 1881-1898. 
Indiana Limestone Company (ILCO).

1962: ILCO Specification Manual.

Jerwood, L., Robinson, D., Williams, R.

1990: Experimental frost and salt weathering of chalk-I; Earth Surface

Processes and Landforms, V. 15, p. 611-624.

Kauffmann, J.

1960: Corrosion et protection des pierres calcaires des monuments; Corrosion et Anticorrosion, Vol. 8, No. 3, p. 87-95.

Kaye, C.

1957: The effect of solvent motion on limestone in solution; The Journal of Geology, Vol. 65, p. 35-46.

Kertesz, P.

1990: Decay and conservation of Hungarian building stones; Environment, Geology and Water Sciences, V. 16, N0. 1, p. 3-7.

Litvan, G.

1976: Frost action in cement in the presence of de-icers; Cement and Concrete Research, V. 6, No. 3, pp. 6.

Litvan, G.

1982: Frost action in porous systems; Internal report for the National Research Council, Division of Building Research.

Livingston, R., Baer, N.

1990: Use of tombstones in investigation of deterioration of stone monuments;

Environment, Geology, and Water Sciences, V. 16, No. 1, p. 83-90. 
Loughlin, G.

1931: Notes on the weathering of natural building stones; American Society for Testing Materials, Proc., Vol. 3, No. II, p. 759-767.

Maage, $M$.

1984: Frost resistance and pore size distribution in bricks; Materiaux et Constructions, V. 17, No. 101, p. 345-350.

Millot, G., Cogne, J.

1967: La maladie de gres de la cathedrale de Strasbourg; Bulletin Service de Carte Geologie, Alsace-Lorraine, Vol. 20, No. 3, p. 131-157.

Olliers, C.

1969: Weathering. Oliver and Boyd, Edinburgh, 304 p.

Public Works, Canada (John Page).

1868: Annual Report on the Public Buildings at Ottawa: Appendix No. 21, p. 201-243.

Schaffer, R.

1932: The weathering of natural building stones; Dept. Sci. Ind. Res., Building Resources Special Report 18, p.1-149.

Silverman, M., Munoz, E.

1970: Fungal attack on rock: solubilization and altered infrared spectra;

Science, Vol. 169, p.985-987.

Schenk, D., Peterson, A., Matthess, G.

1989: Accelleration and retardation of silicate weathering due to organic substances;

Sharp, A., Trudgill, S., Cooke, R., Price, C., Crabtree, R., Pickles, A., Smith, D. 1982: Weathering of the ballustrade on St. Paul's cathedral, London; Earth Surface Processes and Landforms, V. 7, p. 387-389. 
Stitcher, H., Bach, R.

1966: Fundamentals in the chemical weathering of silicates;

Soils and Fertilizers. V. 29, p.321-325.

Trudgill, S., Viles, H., Inkpen, R., Cooke, R.

1989: Remeasurement of weathering rates, St. Paul's Cathedral, London; Earth

Surface Processes and Landforms. V. 14, p. 175-196.

Verbeck, G., Klieger, P.

1956: Studies of the salt scaling of concrete; HRB Bulletin.

V. 150 , p. 1-13.

Vos, B., Tammes, E.

1969: Moisture and moisture transfer in porous materials;

Rpt. Nr. B 1-69-96, Inst. TNO for Building Structures. Delft, Holland.

Voute, C.

1969: Indonesia, geological and hydrological problems involved in the preservation of the monument of Borobudur; Unesco Rpt. Ser. No. 1241/BMS. RD/CLT; Paris, 37 p.

Wilson, A.

1956: A Guide to the Geology of the Ottawa District. The

Canadian Field Naturalist. Vol. 70, No. 1.

Winkler, E.

1966: Important agents of weathering for building and monumental stone; Engineering Geology. V. 1, No. 5, p. 381-400.

Winkler, E.

1987: Weathering and weathering rates of natural stone; Environment, Geology and Water Sciences. V. 9, No. 2, p. 85-92. 
Winkler, E., Wilhelm, E.

1970: Saltburst by hydration pressures in architectural

stone in urban atmosphere; Geol. Soc. America Bulletin. V.

81 , No. 2, p. 567-572.

Winkler, E.

1973: Stone: Properties, Durability in Man's Environment.

Springer Verlag, Wien New York, 230 p.

Xidakis, G., Diamantis, J., Marinos, P.

1990: Building stones and geological environment in three ancient cities of Aegean

Thrace, Greece; Environment, Geology and Water Sciences. V. 16, No. 1, p. 91-101. 
Appendix I

Analytical and Experimental Data 


\section{ABSORPTION AND SPECIFIC GRAVITY}

\begin{tabular}{|l|rrr|rrr||}
\hline Sample & \multicolumn{3}{|c|}{ Absorption } & \multicolumn{3}{|c|}{ Specific Gravity } \\
\hline String 1 & 2 days & 4 weeks & 6 weeks & 2 days & 4 weeks & 6 weeks \\
F1 & & & & & & \\
F2 & $0.88 \%$ & $1.40 \%$ & $2.67 \%$ & 2.42 & 2.41 & 2.41 \\
G3 & $4.66 \%$ & $5.58 \%$ & $6.08 \%$ & 2.28 & 2.24 & 2.24 \\
F4 & $7.64 \%$ & $10.07 \%$ & $11.12 \%$ & 2.04 & 2.00 & 2.04 \\
F5 & $5.86 \%$ & $7.84 \%$ & $8.57 \%$ & 2.08 & 2.07 & 2.09 \\
G6 & $3.23 \%$ & $3.87 \%$ & $4.56 \%$ & 2.40 & 2.31 & 2.42 \\
F7 & $0.08 \%$ & $0.31 \%$ & $0.85 \%$ & 2.64 & 2.61 & 2.67 \\
F8 & $0.00 \%$ & $0.29 \%$ & $0.44 \%$ & 2.72 & 2.74 & 2.72 \\
F9 & $0.00 \%$ & $0.03 \%$ & $0.17 \%$ & 2.62 & 2.61 & 2.63 \\
F10 & $0.18 \%$ & $0.18 \%$ & $0.85 \%$ & 2.58 & 2.57 & 2.61 \\
F11 & $0.11 \%$ & $0.39 \%$ & $0.84 \%$ & 2.57 & 2.54 & 2.60 \\
F12 & $0.00 \%$ & $0.22 \%$ & $0.28 \%$ & 2.58 & 2.46 & 2.54 \\
F13 & $0.35 \%$ & $0.35 \%$ & $0.42 \%$ & 2.57 & 2.51 & 2.56 \\
F14 & $0.17 \%$ & $0.17 \%$ & $0.17 \%$ & 2.51 & 2.63 & 2.67 \\
String 2 & $0.00 \%$ & $0.03 \%$ & $0.55 \%$ & 2.80 & 2.78 & 2.82 \\
G1 & & & & & & \\
G2 & $2.75 \%$ & $3.73 \%$ & $4.22 \%$ & 2.42 & 2.41 & 2.33 \\
A3 & $4.15 \%$ & $5.59 \%$ & $6.00 \%$ & 2.25 & 2.21 & 2.27 \\
H4 & $7.67 \%$ & $9.69 \%$ & $10.81 \%$ & 2.11 & 2.00 & 2.00 \\
G5 & $5.87 \%$ & $7.17 \%$ & $8.42 \%$ & 2.09 & 2.15 & 2.15 \\
H6 & $3.67 \%$ & $4.37 \%$ & $4.67 \%$ & 2.31 & 2.33 & 2.38 \\
& $0.11 \%$ & $0.15 \%$ & $0.28 \%$ & 2.60 & 2.61 & 2.66 \\
N8 & & & & & & \\
G9 & $0.00 \%$ & $0.00 \%$ & $0.34 \%$ & 2.64 & 2.56 & 2.64 \\
& $0.31 \%$ & $0.31 \%$ & $0.52 \%$ & 2.47 & 2.56 & 2.59 \\
G11 & & & & & & \\
G12 & $0.21 \%$ & $0.44 \%$ & $0.68 \%$ & 2.40 & 2.50 & 2.55 \\
ASTM & $0.00 \%$ & $0.19 \%$ & $0.41 \%$ & 2.58 & 2.56 & 2.59 \\
NEPEAN & $1.51 \%$ & $1.98 \%$ & $2.19 \%$ & 2.42 & 2.42 & 2.42 \\
WALLACE & $4.23 \%$ & $4.87 \%$ & $5.09 \%$ & 2.27 & 2.28 & 2.28 \\
OHIO & $6.70 \%$ & $8.18 \%$ & $8.79 \%$ & 2.08 & 2.08 & 2.08 \\
COBURG & $0.30 \%$ & $0.33 \%$ & $0.24 \%$ & 2.69 & 2.68 & 2.68 \\
GRANITE & $0.25 \%$ & $0.49 \%$ & $0.24 \%$ & 2.63 & 2.62 & 2.64 \\
\hline
\end{tabular}

Absorption and Bulk Specific Gravity data. 


\section{$\mathrm{X}$-Ray analysis of samples}

\begin{tabular}{|c|c|c|c|c|c|}
\hline \multicolumn{6}{|c|}{ Minerals Present } \\
\hline Sample & \begin{tabular}{|l} 
Minerals \\
\end{tabular} & rom X-ra & diffraction & & Source \\
\hline $\begin{array}{l}\text { Nepean Sandstone } \\
\text { Wallace sandstone } \\
\text { Ohio sandstone } \\
\text { Indiana Limestone } \\
\text { Tyndal Limestone } \\
\text { Coburg limestone } \\
\text { Disraeli strom. } \\
\text { Carera marble } \\
\text { Hampstead granite } \\
\text { White granite } \\
\text { Red granite } \\
\text { Rapakevi granite } \\
\text { Light anorthosite } \\
\text { Dark anorthosite } \\
\text { Efflorescence } \\
\text { Efflorescence } \\
\text { Efflorescence } \\
\text { Efflorescence }\end{array}$ & $\begin{array}{l}\text { quartz } \\
\text { quartz } \\
\text { quartz } \\
\text { calcite } \\
\text { calcite } \\
\text { calcite } \\
\text { dolomite } \\
\text { calcite } \\
\text { mica } \\
\text { mica } \\
\text { mica } \\
\text { mica } \\
\text { mica } \\
\text { mica } \\
\text { gypsum } \\
\text { halite } \\
\text { halite } \\
\text { gypsum }\end{array}$ & $\begin{array}{l}\text { mica } \\
\text { mica } \\
\text { quartz } \\
\text { quartz } \\
\text { quartz } \\
\text { quartz } \\
\text { quartz } \\
\text { quartz } \\
\text { quartz } \\
\text { quartz } \\
\text { feldspar } \\
\text { feldspar }\end{array}$ & $\begin{array}{l}\text { kaolinite } \\
\text { kaolinite } \\
\text { dolomite } \\
\text { calcite } \\
\text { dolomite } \\
\text { feldspar } \\
\text { feldspar } \\
\text { feldspar } \\
\text { feldspar } \\
\text { amphibole }\end{array}$ & $\begin{array}{l}\text { feldspar } \\
\text { feldspar }\end{array}$ & $\begin{array}{l}\text { Parliament Bldgs. } \\
\text { Parliament Bldgs. } \\
\text { Parliament Bldgs. } \\
\text { Parliament Bldgs. } \\
\text { Parliament Bldgs. } \\
\text { Daly Bldg. } \\
\text { Disraeli Lake } \\
\text { Italy } \\
\text { Parliament Bldgs. } \\
\text { unknown } \\
\text { unknown } \\
\text { unknown } \\
\text { unknown } \\
\text { unknown } \\
\text { Ohio s.s./Parliament } \\
\text { Ohio s.s./Parliament } \\
\text { mortar/ Parliament } \\
\text { Nepean s.s./Parliament }\end{array}$ \\
\hline
\end{tabular}

$\mathrm{X}$-ray analyses data for the rock samples used in other experiments and analyses. 


\begin{tabular}{|l|r|r|r|r|r|}
\hline \hline \multicolumn{7}{|c|}{ DROPLET TEST } \\
\hline Sample--> & Nepean & \multicolumn{1}{l|}{ Wallace } & \multicolumn{1}{l|}{ Ohio } & \multicolumn{1}{l|}{ Daly } & Granite \\
& & & & & \\
Minutes & 5.30 & 5.47 & 0.05 & 13.22 & 26.38 \\
and & 37.00 & 5.20 & 0.06 & 55.15 & 20.45 \\
seconds & 5.02 & 6.15 & 0.06 & 70.00 & 41.23 \\
& 0.52 & 6.15 & 0.05 & 75.00 & 26.08 \\
& 0.15 & 5.51 & 0.05 & 7.25 & 38.00 \\
& 0.45 & 6.10 & 0.06 & 45.00 & 31.00 \\
& 5.05 & 5.35 & 0.05 & 52.00 & 52.00 \\
\cline { 2 - 7 } Std. Dev. & 13.11 & 0.38 & 0.00 & 26.01 & 7.18 \\
Mean & 8.07 & 5.74 & 0.06 & 44.27 & 30.52 \\
\hline \hline
\end{tabular}

Droplet test: A single drop of water was placed on the surface of a stone block over 5 different sites, and measured for the time to be absorbed. 


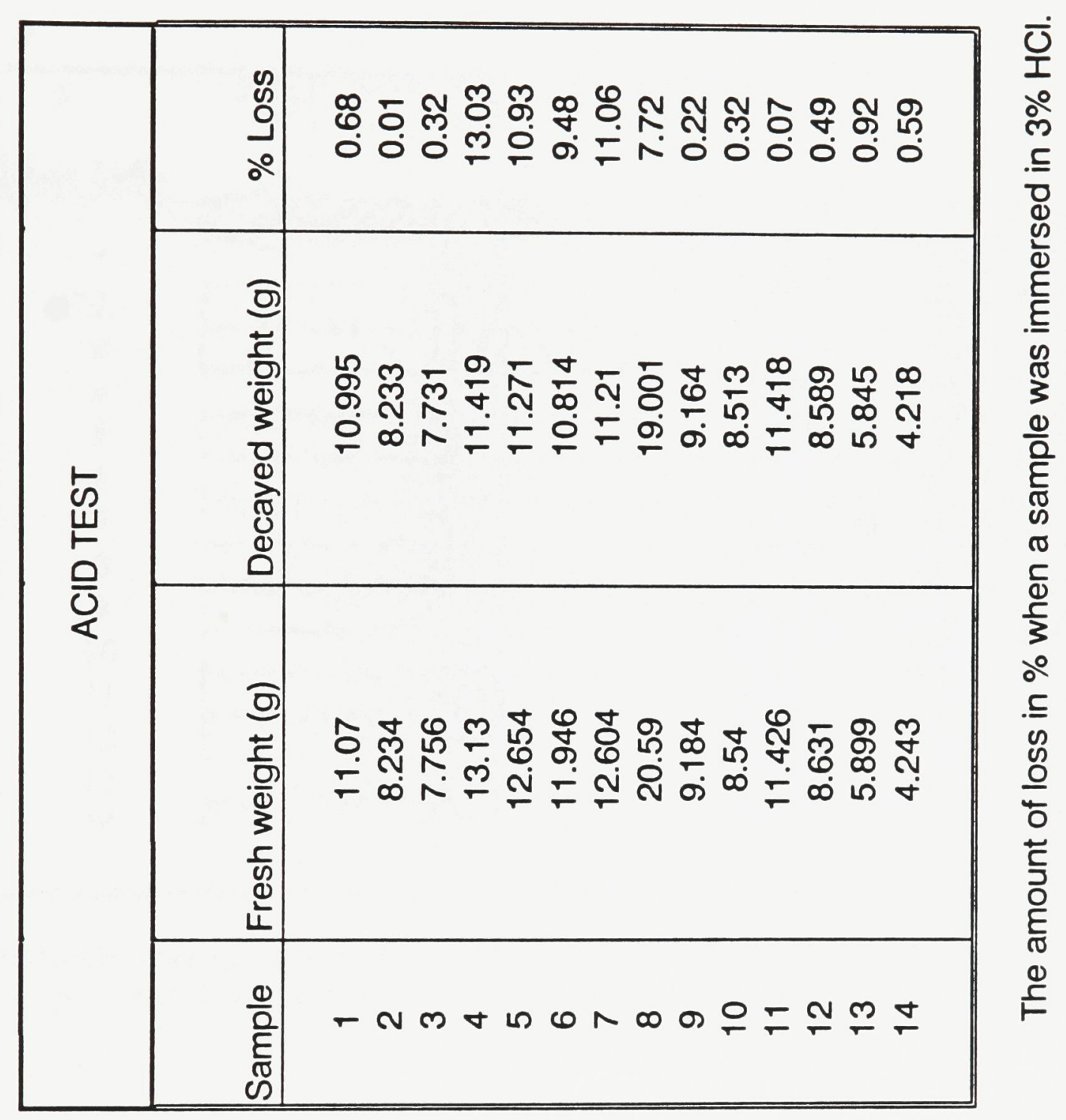




\section{FREEZE/THAW IN SALT TEST}

\section{Rock Type}

\begin{tabular}{|c|c|c|c|c|}
\hline & Fresh sample(g) & 30 Cycles later(g) & $\operatorname{Loss}(\mathrm{g})$ & \% loss \\
\hline 1 & 43.5 & 43.3 & \begin{tabular}{|l}
0.2 \\
\end{tabular} & $0.5 \%$ \\
\hline 2 & 47.1 & 46.7 & 0.4 & $0.8 \%$ \\
\hline 3 & 34.3 & 33.7 & 0.6 & $1.7 \%$ \\
\hline 4 & 14.1 & 13.8 & 0.3 & $2.1 \%$ \\
\hline 5 & 38.2 & 37.7 & 0.5 & $1.3 \%$ \\
\hline 6 & 47.4 & 47 & 0.4 & $0.8 \%$ \\
\hline 7 & 43.6 & 43.3 & 0.3 & $0.7 \%$ \\
\hline 8 & 36.6 & 36.35 & 0.25 & $0.7 \%$ \\
\hline 9 & 51.9 & 51.65 & 0.25 & $0.5 \%$ \\
\hline 10 & 35.9 & 35.55 & 0.35 & $1.0 \%$ \\
\hline 11 & 46.8 & 46.65 & 0.15 & $0.3 \%$ \\
\hline 12 & 31 & 30.75 & 0.25 & $0.8 \%$ \\
\hline 13 & 59.2 & 59.1 & 0.1 & $0.2 \%$ \\
\hline 14 & 70.7 & 70.6 & 0.1 & $0.1 \%$ \\
\hline & \multicolumn{2}{|r|}{ Average } & 0.296 & $0.8 \%$ \\
\hline
\end{tabular}

Samples were repeatedly frozen and thawed in a saline $(\mathrm{NaCl})$ solution for 30 days, and then the \% loss of material was measured. 


\begin{tabular}{|c|c|c|c|c|}
\hline \multicolumn{5}{|c|}{ WET/DRY IN SALT TEST } \\
\hline & Fresh samnle(a) & 30 Cyclec later ( & I $\operatorname{arcs}(\Omega)$ & \\
\hline 1 & 429 & 4265 & $\frac{2000(5)}{025}$ & $00 \%$ \\
\hline 2 & 499 & 49.5 & 0.4 & $0.8 \%$ \\
\hline 3 & 24.6 & 24.05 & 0.55 & $2.2 \%$ \\
\hline 4 & 16.3 & 15.7 & 0.6 & $3.7 \%$ \\
\hline 5 & 41.2 & 40.62 & 0.58 & $1.4 \%$ \\
\hline 6 & 51 & 50.7 & 0.3 & $0.6 \%$ \\
\hline 7 & 39.6 & 39.3 & 0.3 & $0.8 \%$ \\
\hline 8 & 43.1 & 42.9 & 0.2 & $0.5 \%$ \\
\hline 9 & 55.3 & 55.1 & 0.2 & $0.4 \%$ \\
\hline 10 & 42.9 & 42.65 & 0.25 & $0.6 \%$ \\
\hline 11 & 33.2 & 32.95 & 0.25 & $0.8 \%$ \\
\hline 12 & 31.1 & 30.82 & 0.28 & $0.9 \%$ \\
\hline 13 & 60.95 & 60.8 & 0.15 & $0.2 \%$ \\
\hline 14 & 70.1 & 70.05 & 0.05 & $0.1 \%$ \\
\hline & & Average & 0.311 & $1.0 \%$ \\
\hline
\end{tabular}

Samples were repeatedly wetted and dried in a saline $(\mathrm{NaCl})$ solution for 30 cycles, rubbed with a brush each time to remove loose particles, and then measured for loss of material. 
Appendix II

Headstone Algorithm

Turbo $\mathrm{C}++$ 


\section{/* Program Headstone *I \\ $I^{*}$ written in Turbo $\mathrm{C}++* /$}

$I^{*}$ Designed to accept the number of headstones to be used, the */

$I^{*}$ age of each headstone, and 5 depth measurements for each */

$I^{*}$ face. The program computes the average decay rate in $\mathrm{mm} / \mathrm{yr} * /$

/* for each face of each headstone, the average opf each face */

$I^{*}$ all headstones, and the overall average decay rate of */

$I^{*}$ marble headstones. ${ }^{*} /$

\# include <stdio.h>

\# include <stdlib.h>

\# include <conio.h $>$

void main (void)

\{

FILE *fdata;

float stone[50][4][5], stoneAge[50], faceAvg[50][4], globalFaceAvg[4]; int idx, face, reading, numOfStones;

char *side[4] = \{"north", "east", "south", "west" ;

fdata = fopen("stone.dat", "w");

if (fdata $==$ NULL)

\{

printf("Unable to open file: stone.dat");

\}

$\operatorname{exit}(1)$

clrscr();

puts(" $\mid n \backslash n$ Please enter the number of headstones <50:");

printf("|t|t|t-...> ");

fflush(stdin);

scanf("\%d", \&numOfStones);

printf("lnNumber of stones: \%d", numOfStones);

fprintf(fdata, "\%d\n", numOfStones);

for $($ face $=0$, face $<4$, face ++ )

globalFaceAvg $=0.0$;

for $(\mathrm{idx}=0, \mathrm{idx}<$ numOfStones, $\mathrm{idx}++)$

\{

printf(InStone \# \%d, idx+1);

printf("Please enter stone age: "); 


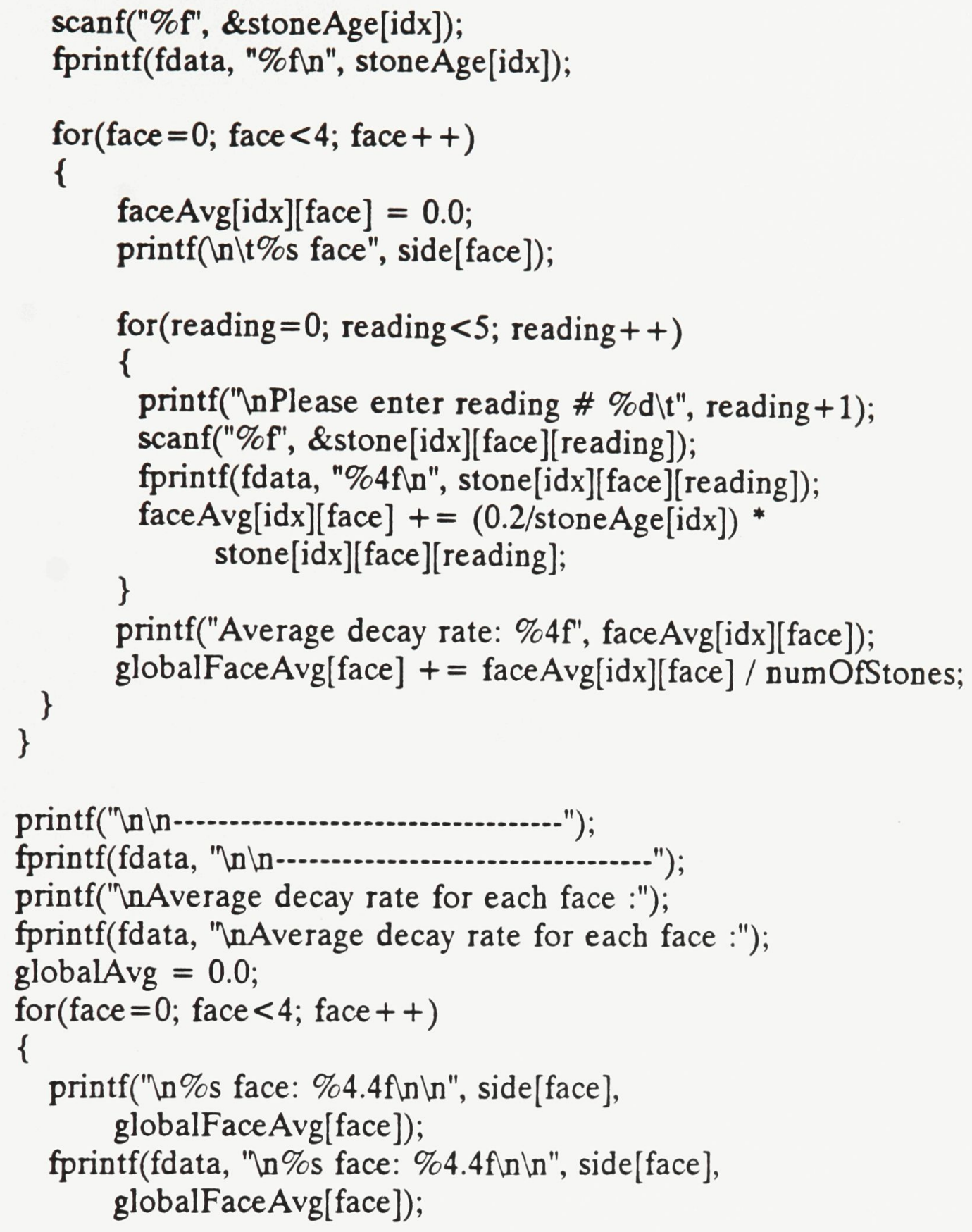


INPUT 
6

0.470000

Age: 121.000000

0.440000

0.470000

0.450000

0.460000

0.190000

0.190000

0.260000

0.210000

0.250000

0.230000

0.160000

0.100000

0.260000

0.250000

0.180000

0.130000

0.150000

0.180000

0.150000

Age: 119.000000

0.590000

0.610000

0.680000

0.530000

0.590000

0.880000

0.930000

0.900000

0.880000

0.910000

0.700000

0.770000

0.660000

0.690000

0.730000

0.740000

0.750000

0.830000

0.970000

0.950000

Age: 124.000000 
0.190000

0.180000

0.170000

0.290000

0.300000

0.510000

0.600000

0.300000

0.640000

0.600000

0.860000

0.780000

0.250000

0.260000

0.290000

0.800000

0.640000

0.810000

0.670000

0.820000

0.690000

Age: 128.000000

0.550000

0.500000

0.460000

0.450000

0.700000

0.480000

0.530000

0.530000

0.540000

0.630000

0.620000

0.720000

0.650000

0.640000

0.940000

0.620000

0.630000

0.590000

0.610000

Age: 104.000000

0.440000

0.420000 

0.540000
0.460000
0.430000
0.430000
0.420000
0.530000
0.600000
0.440000
0.490000
0.470000
0.390000
0.420000
0.460000
0.380000
0.530000
0.570000
0.370000
0.410000

0.500000

Age: 135.000000

0.320000

0.600000

0.610000

0.540000

0.420000

0.440000

0.390000

0.430000

0.420000

0.370000

0.390000

0.490000

0.420000

0.410000

0.320000

0.540000

0.480000

0.360000

0.380000 
APPENDIX III

Drill Hole Logs 
Hole 1 : Billings Bridge, Ottawa. 


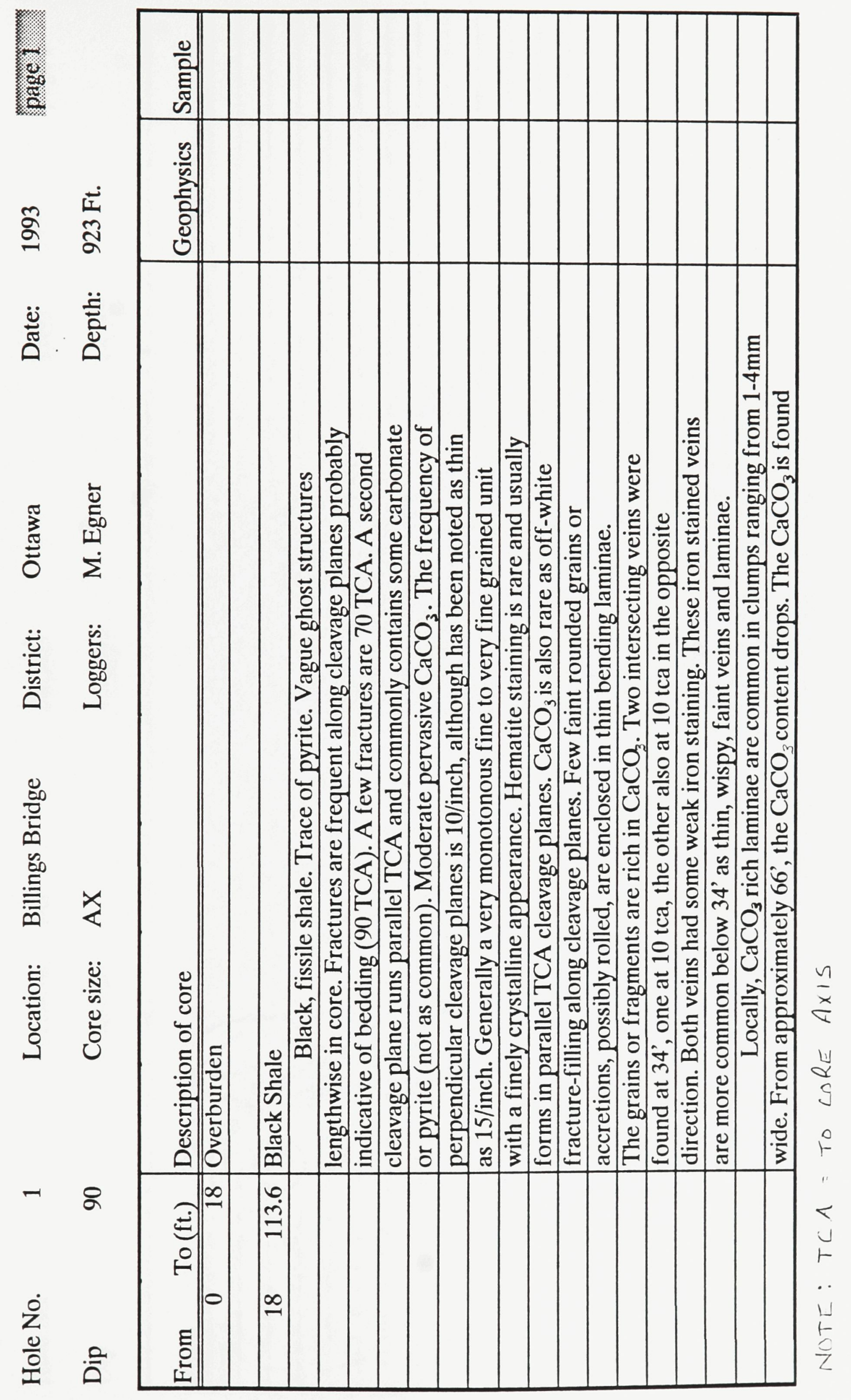




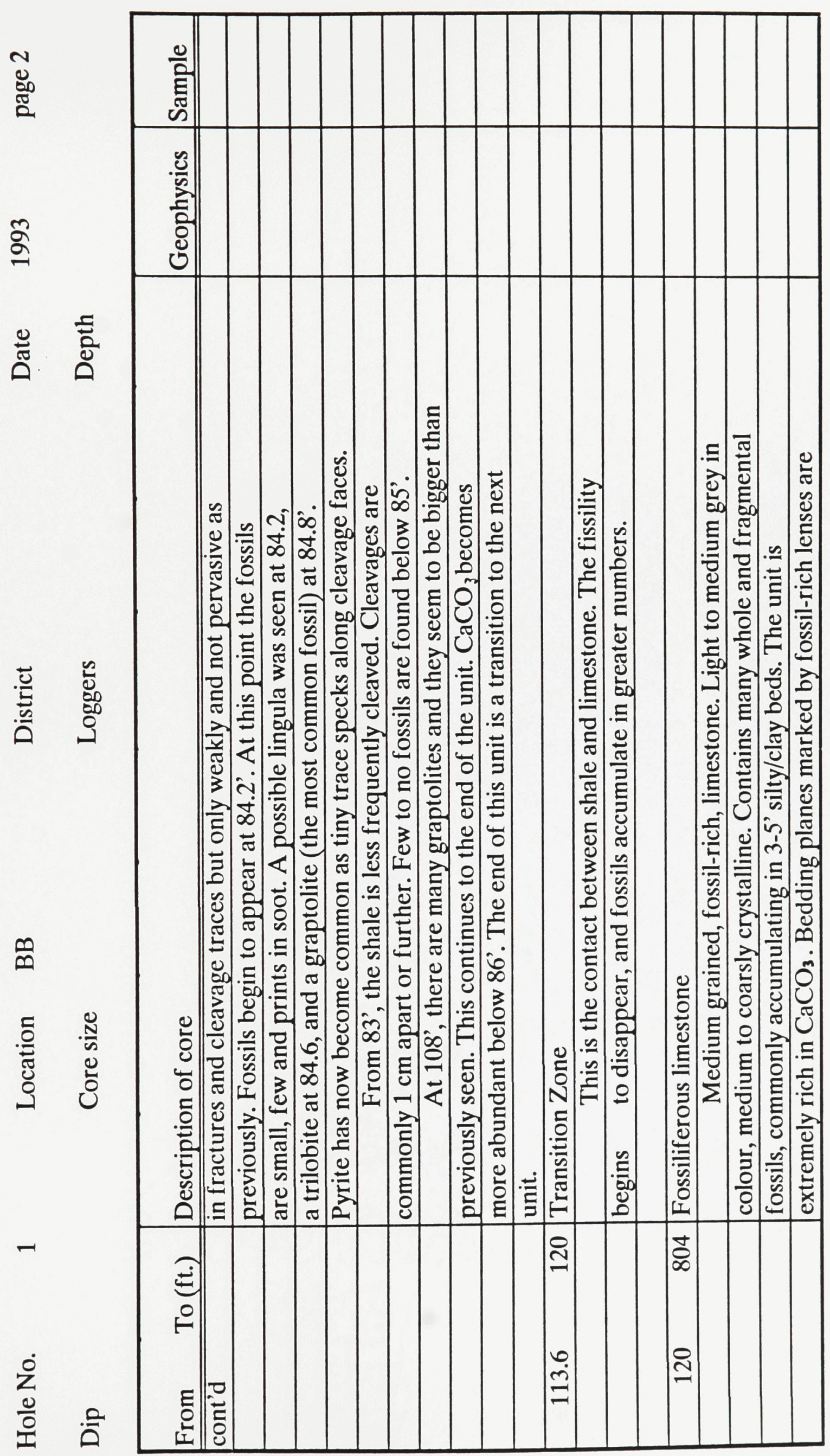




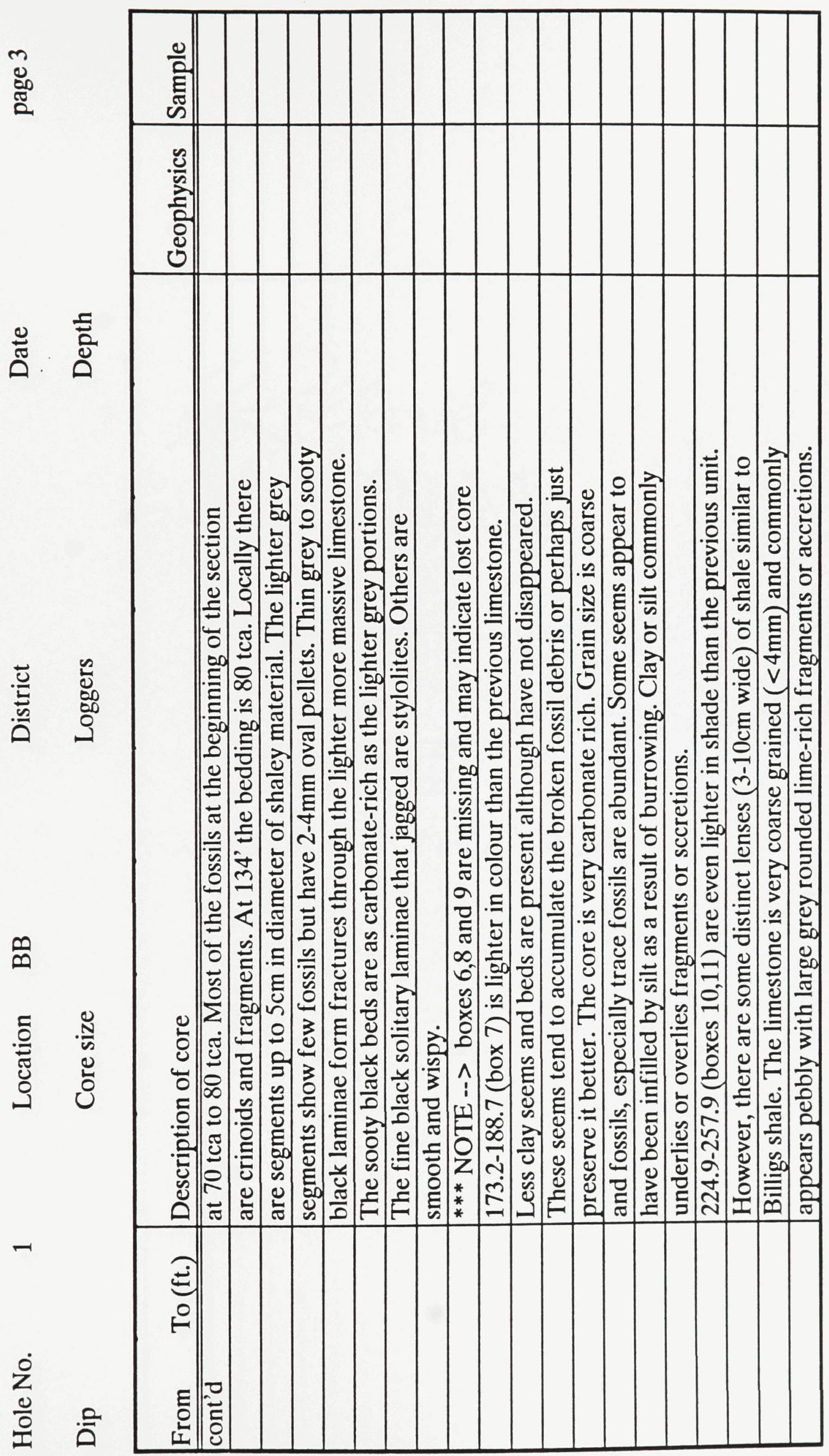




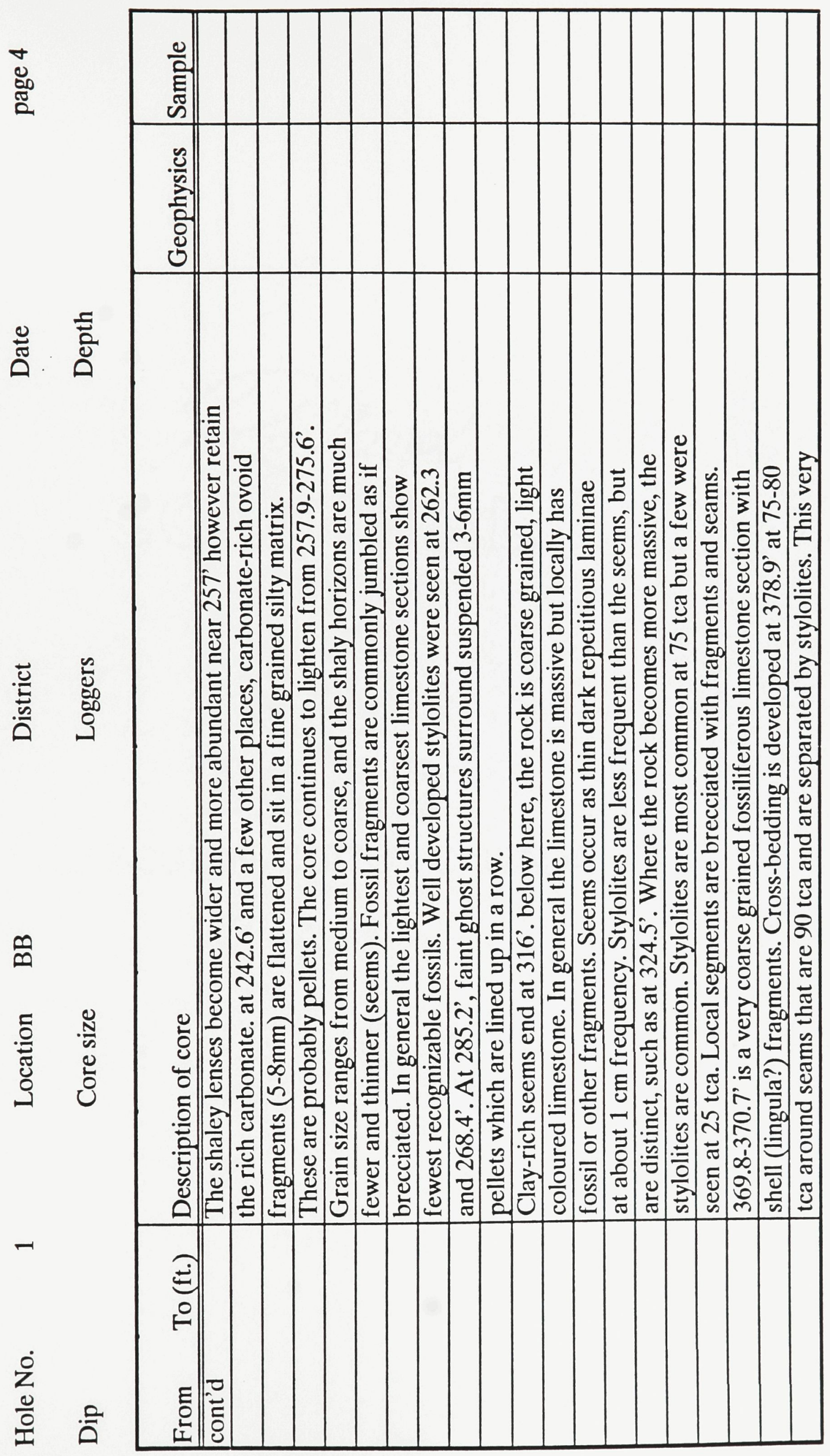




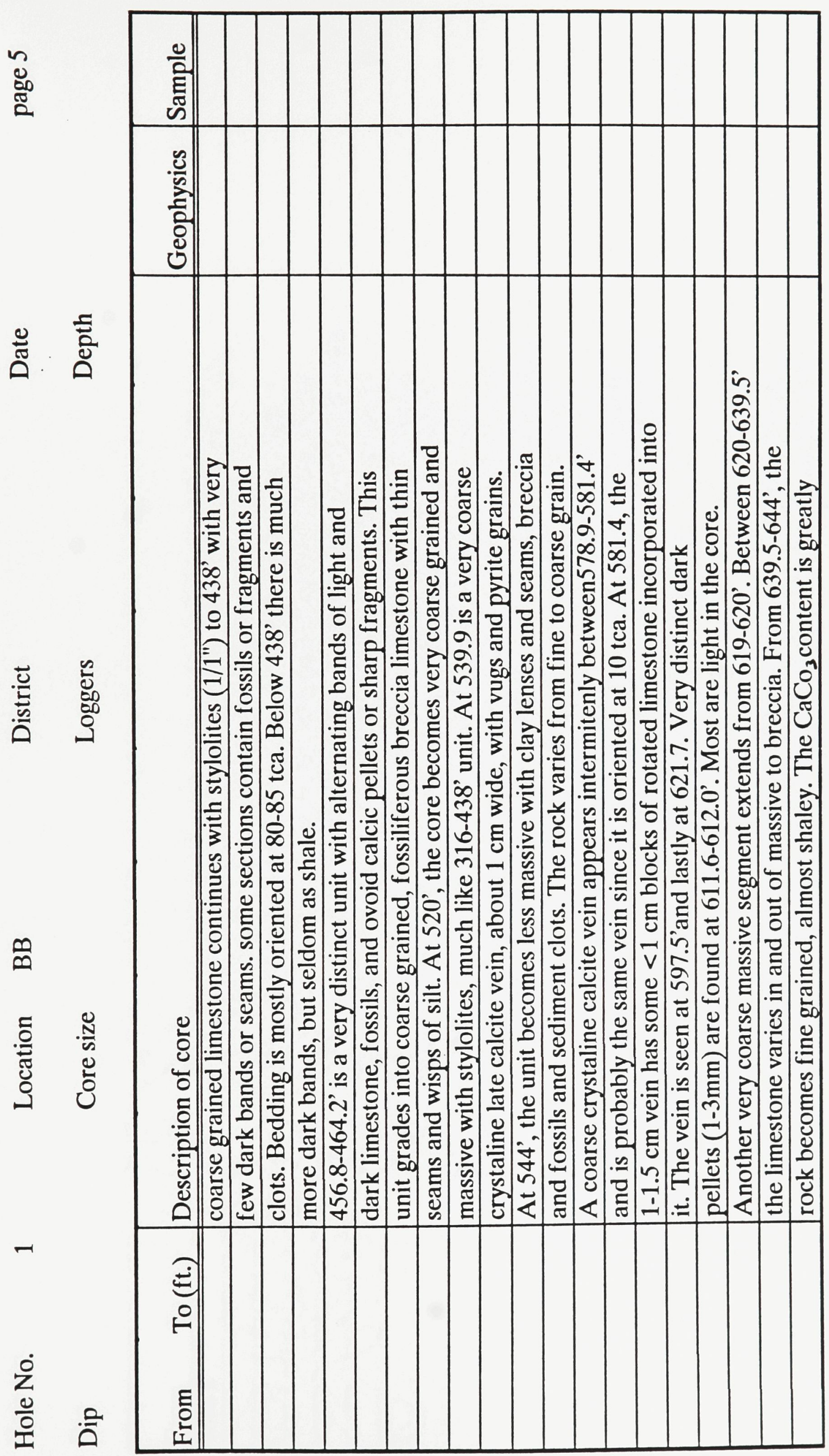




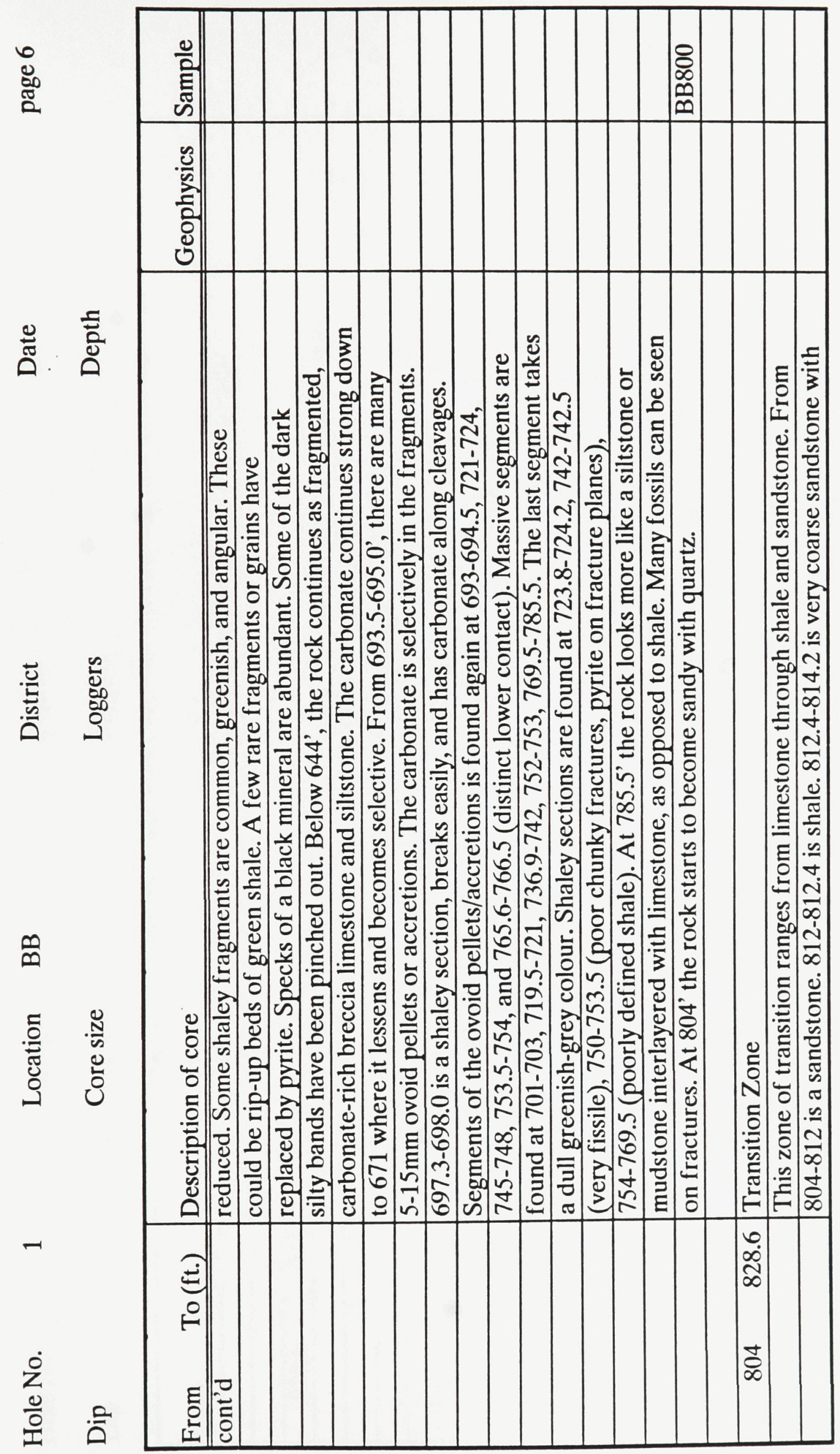




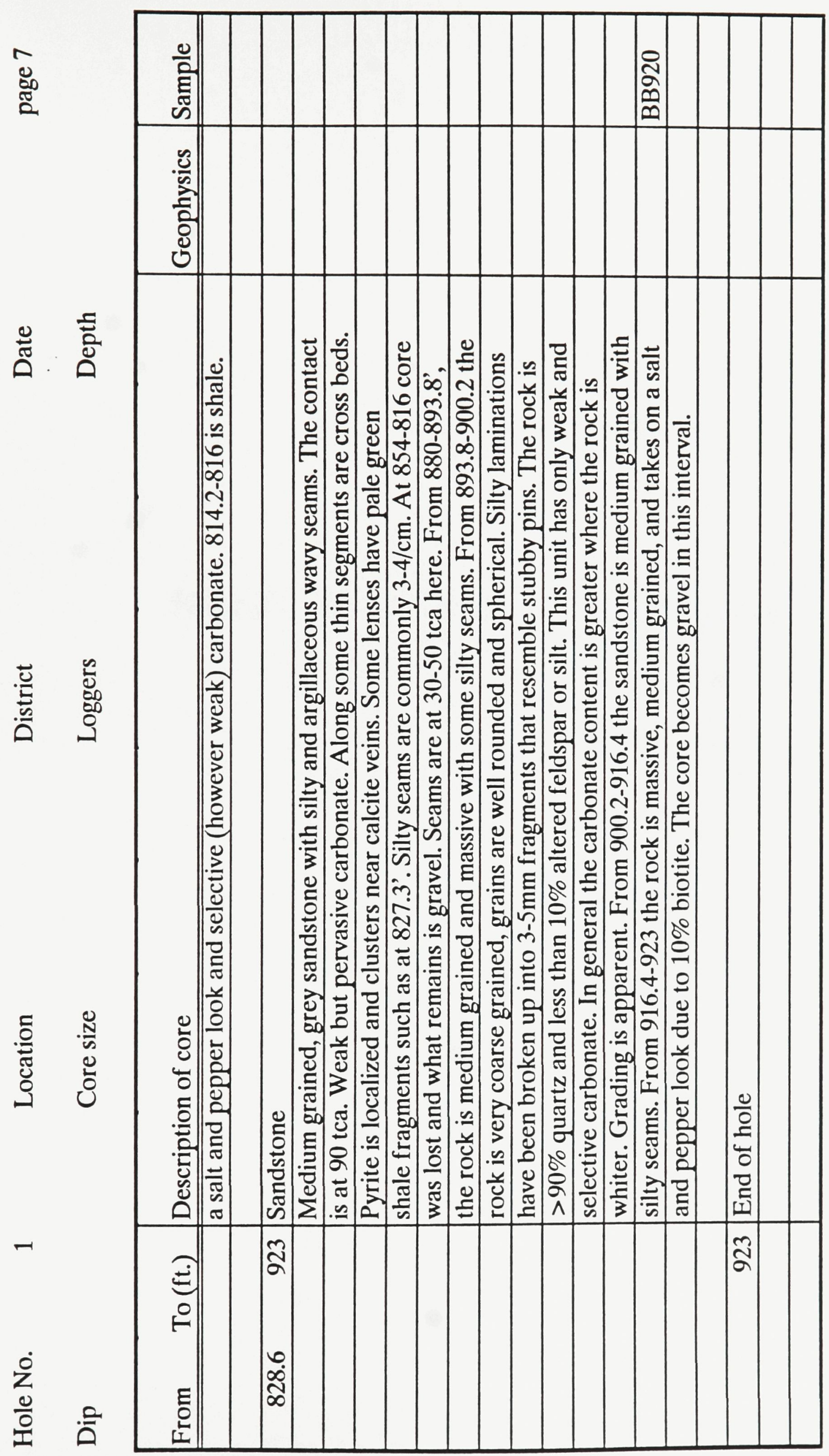


Hole 2 : Bells Corners, Carleton County. 


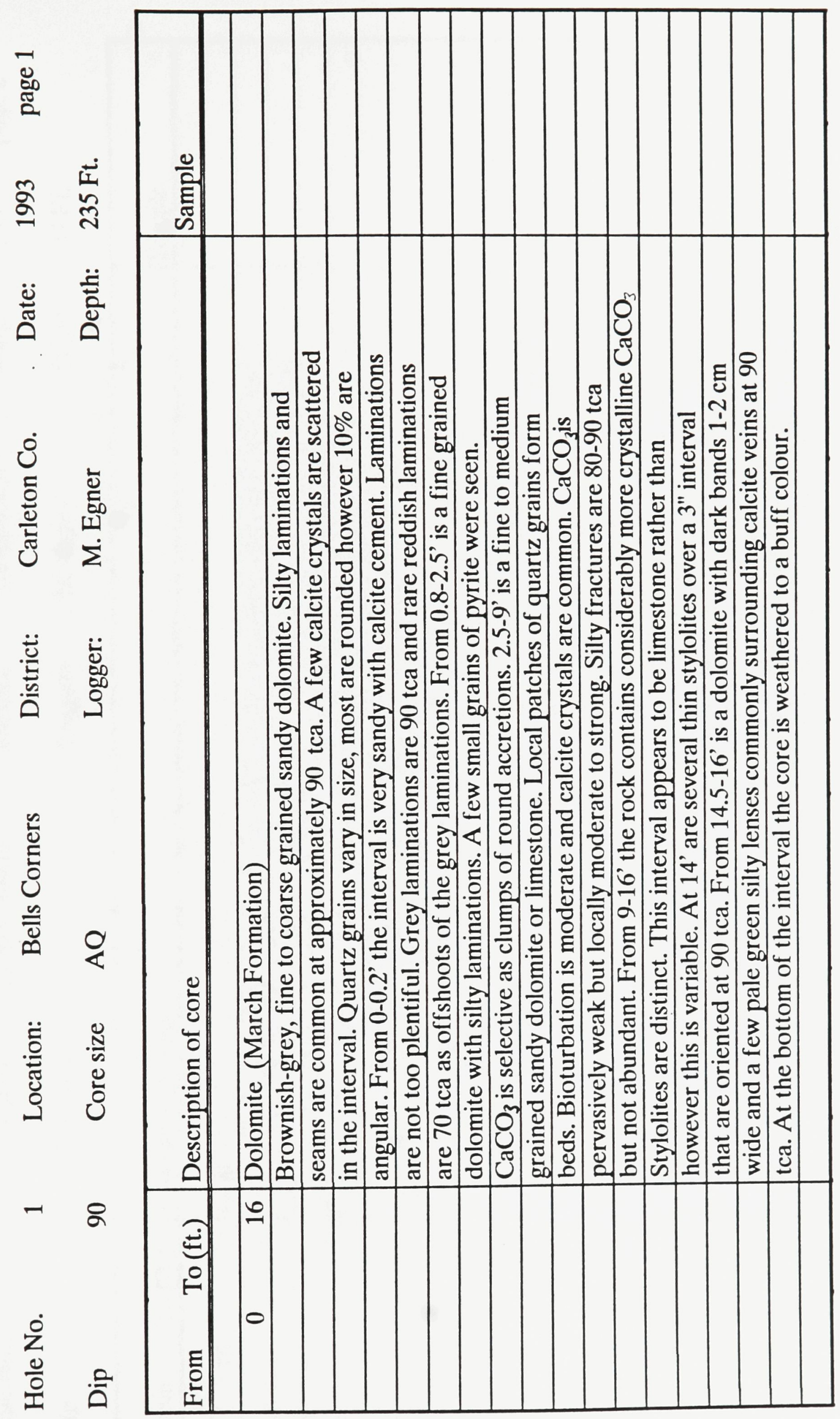




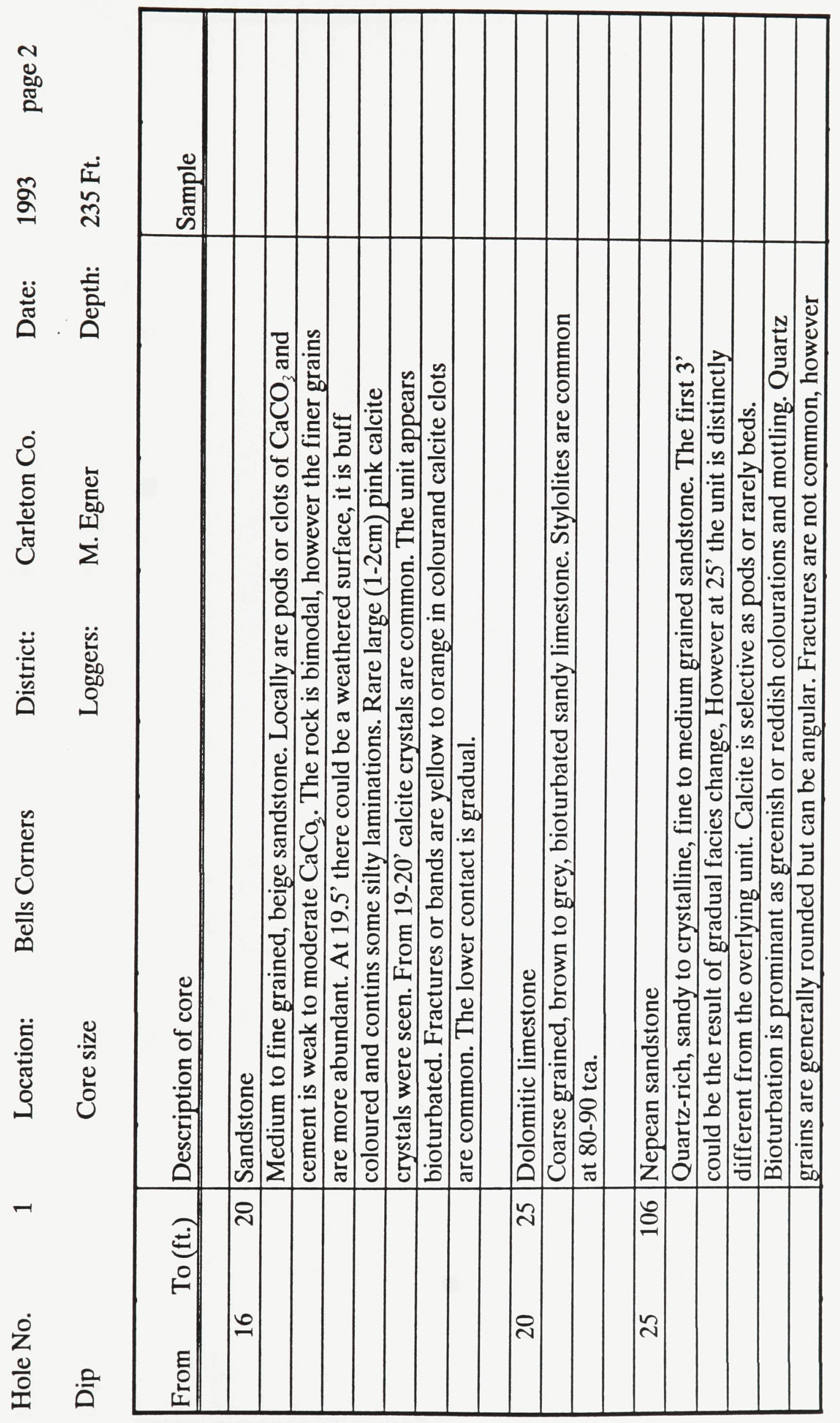




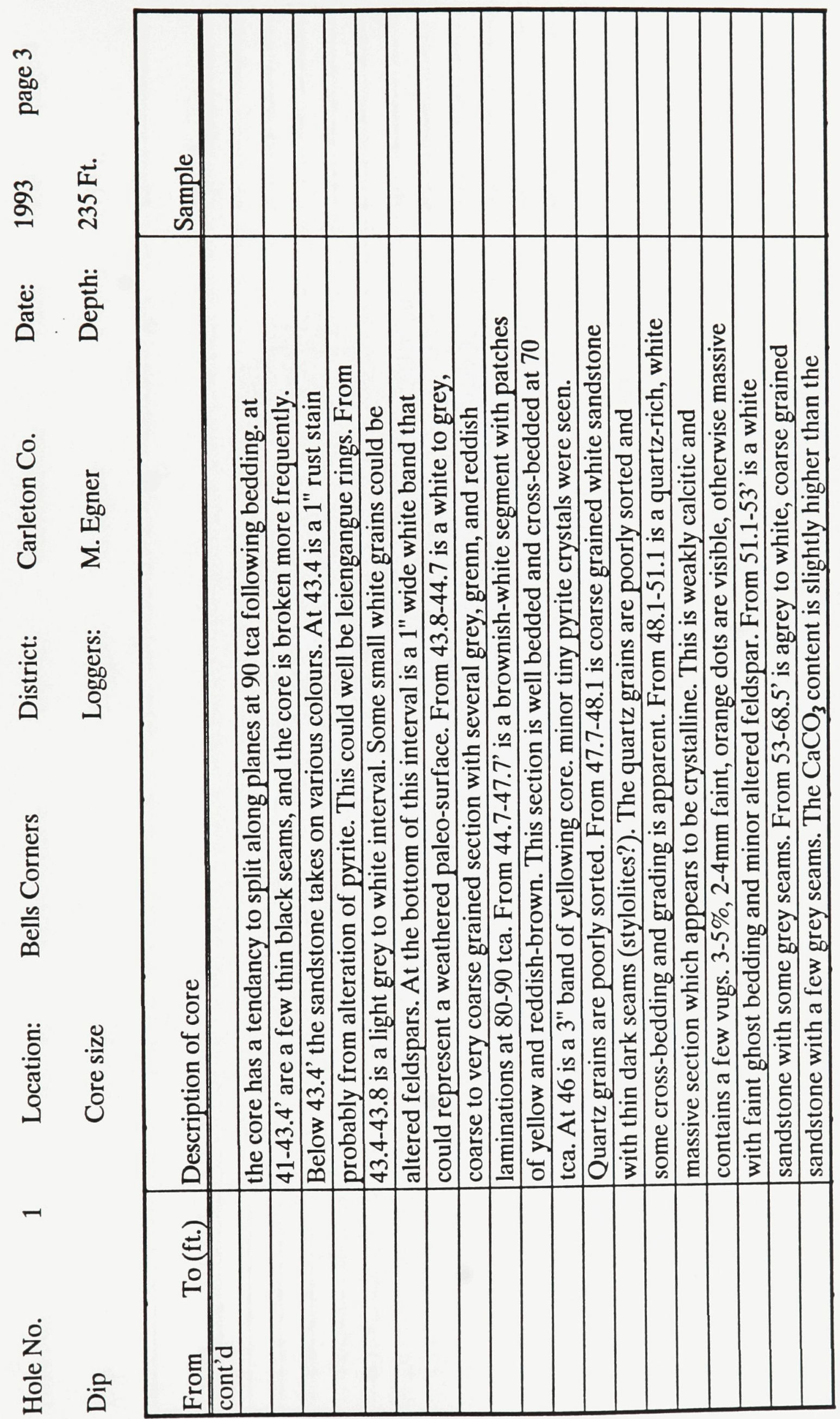




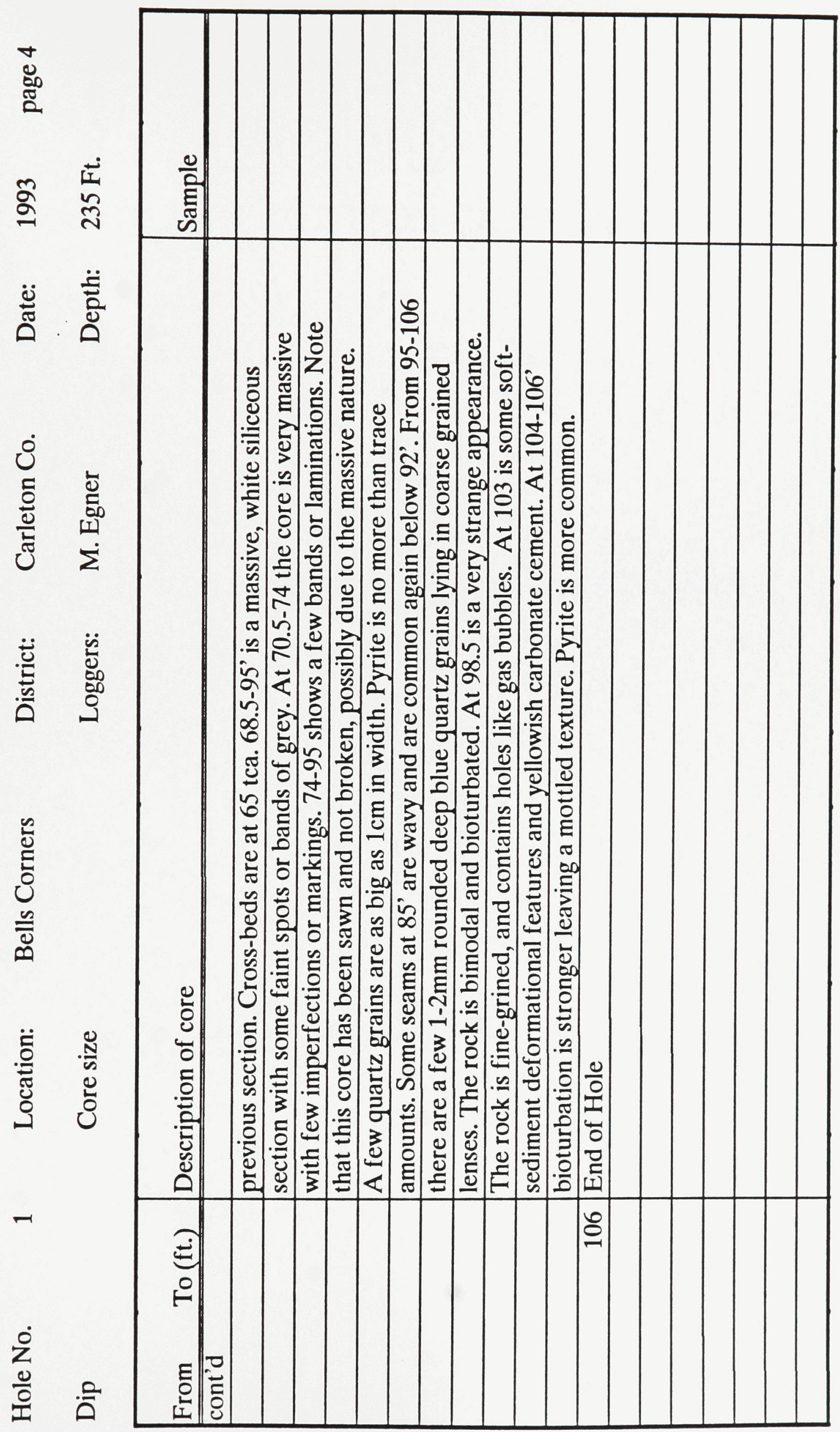


Hole 3 : Lanark, Lanark County. 


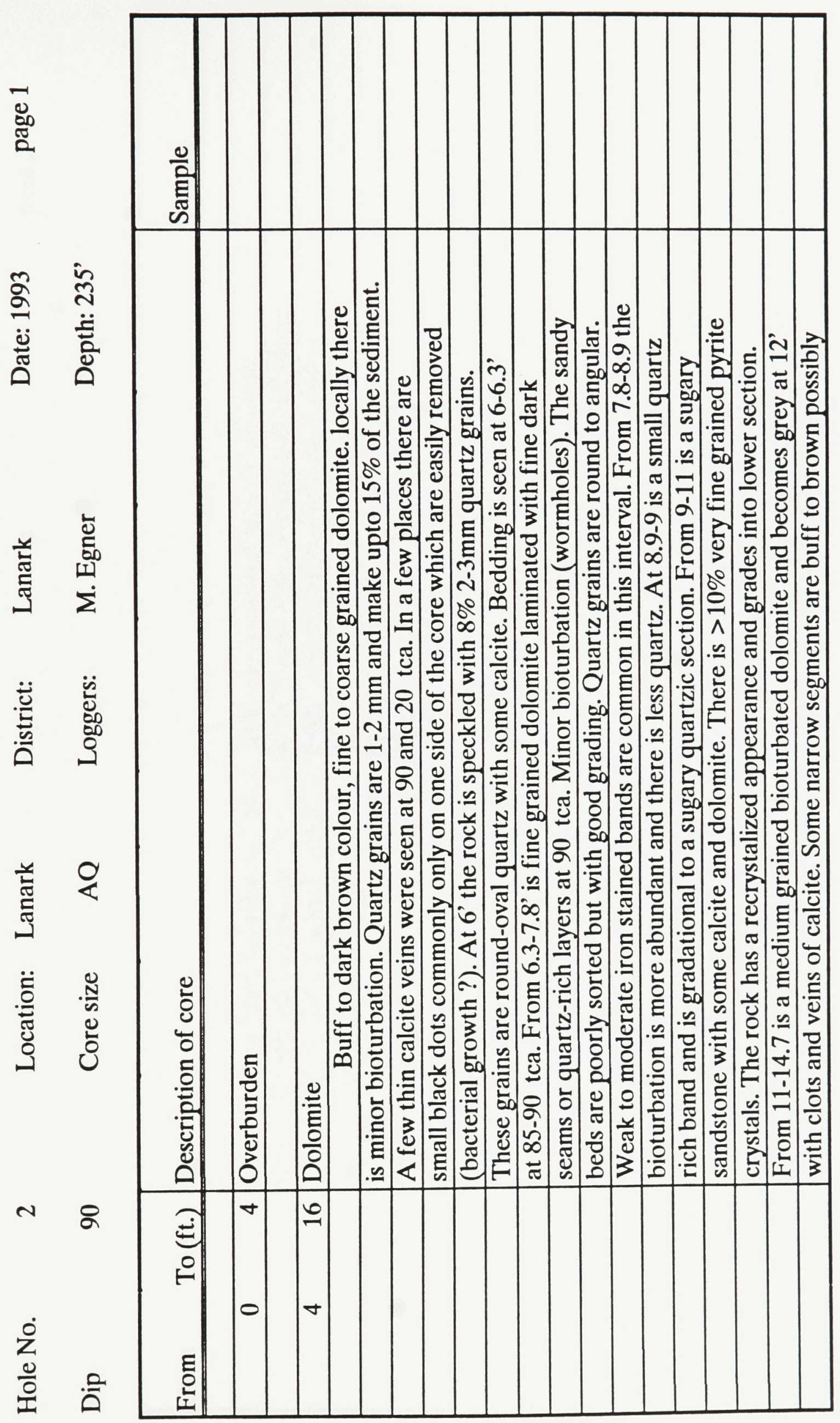




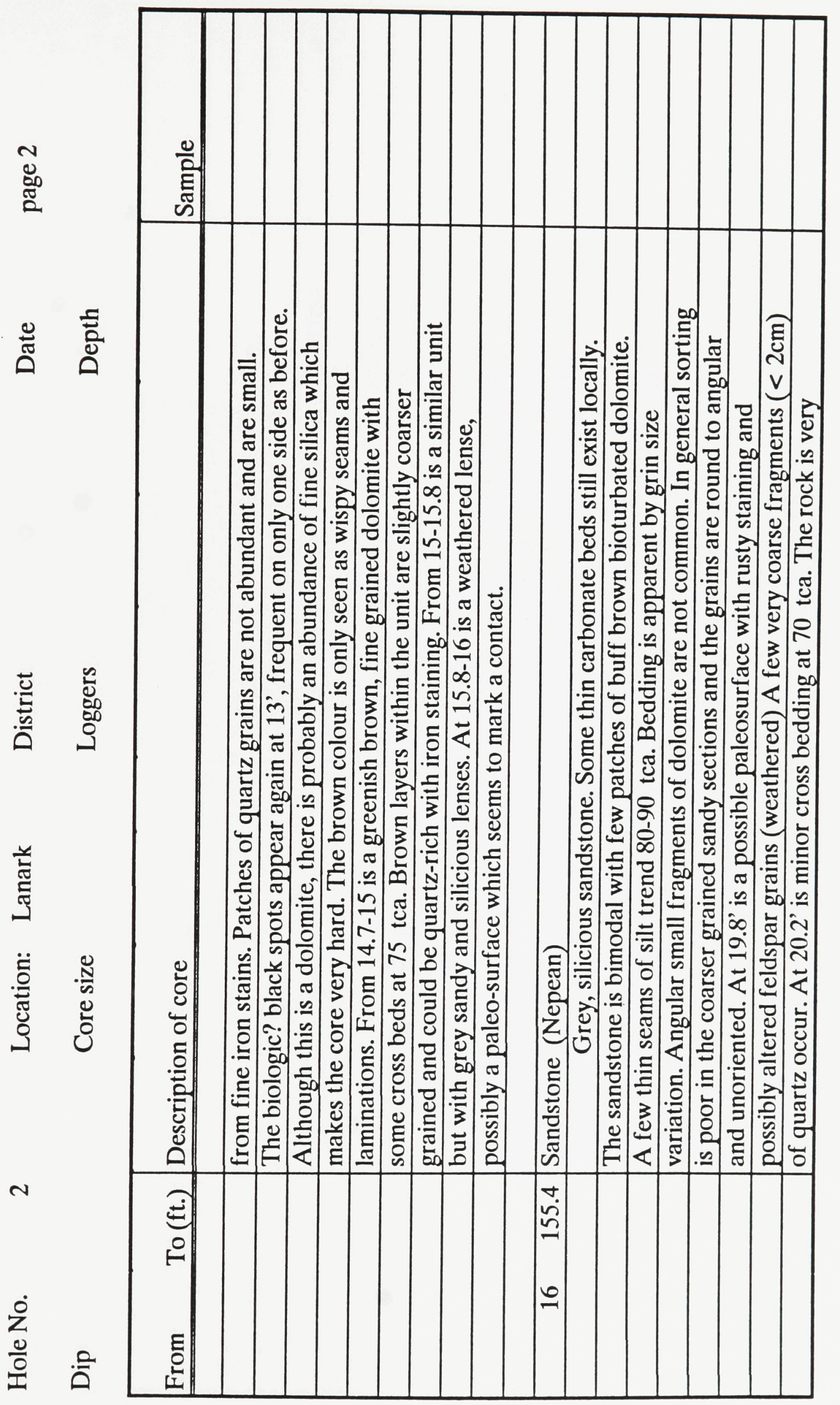




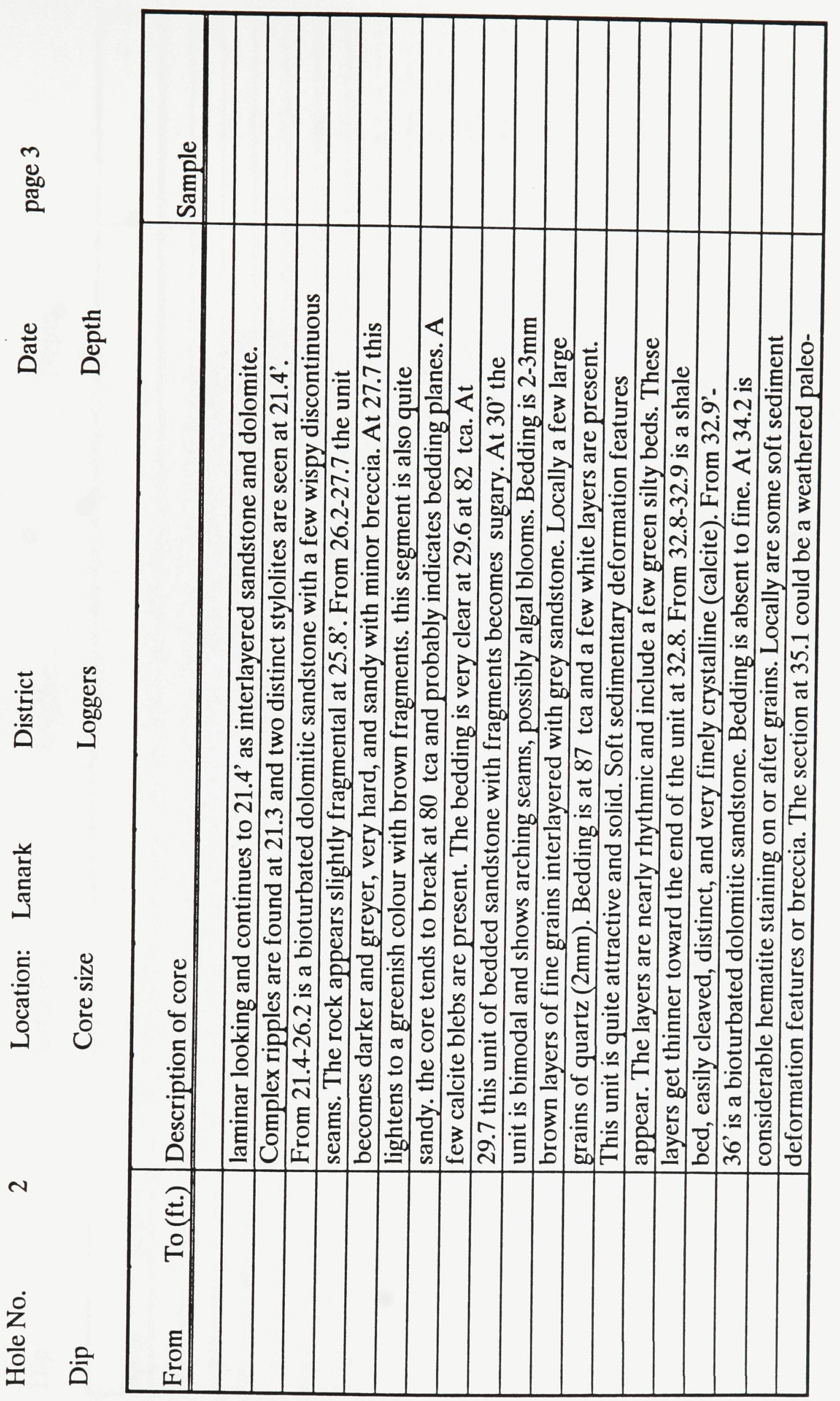




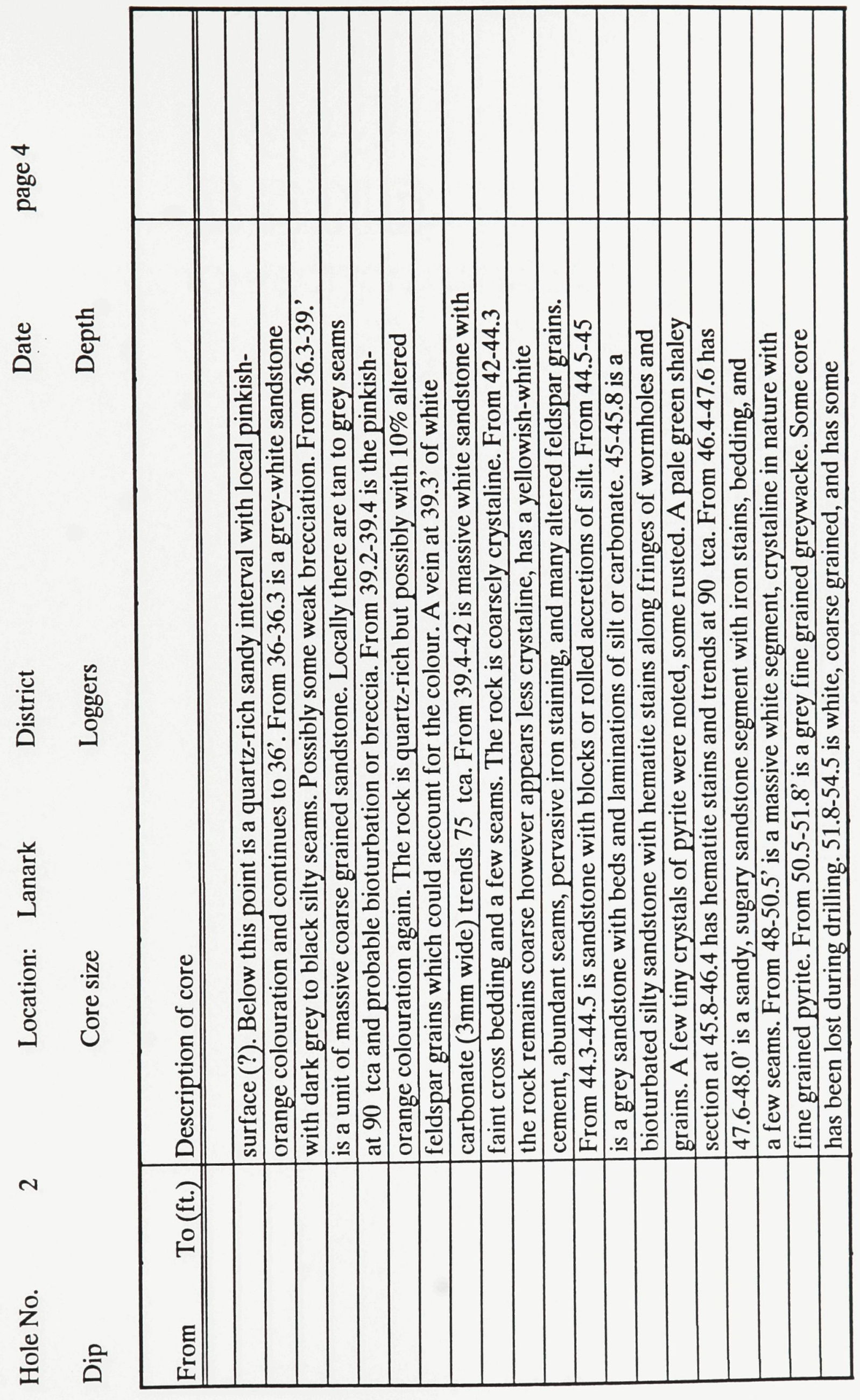




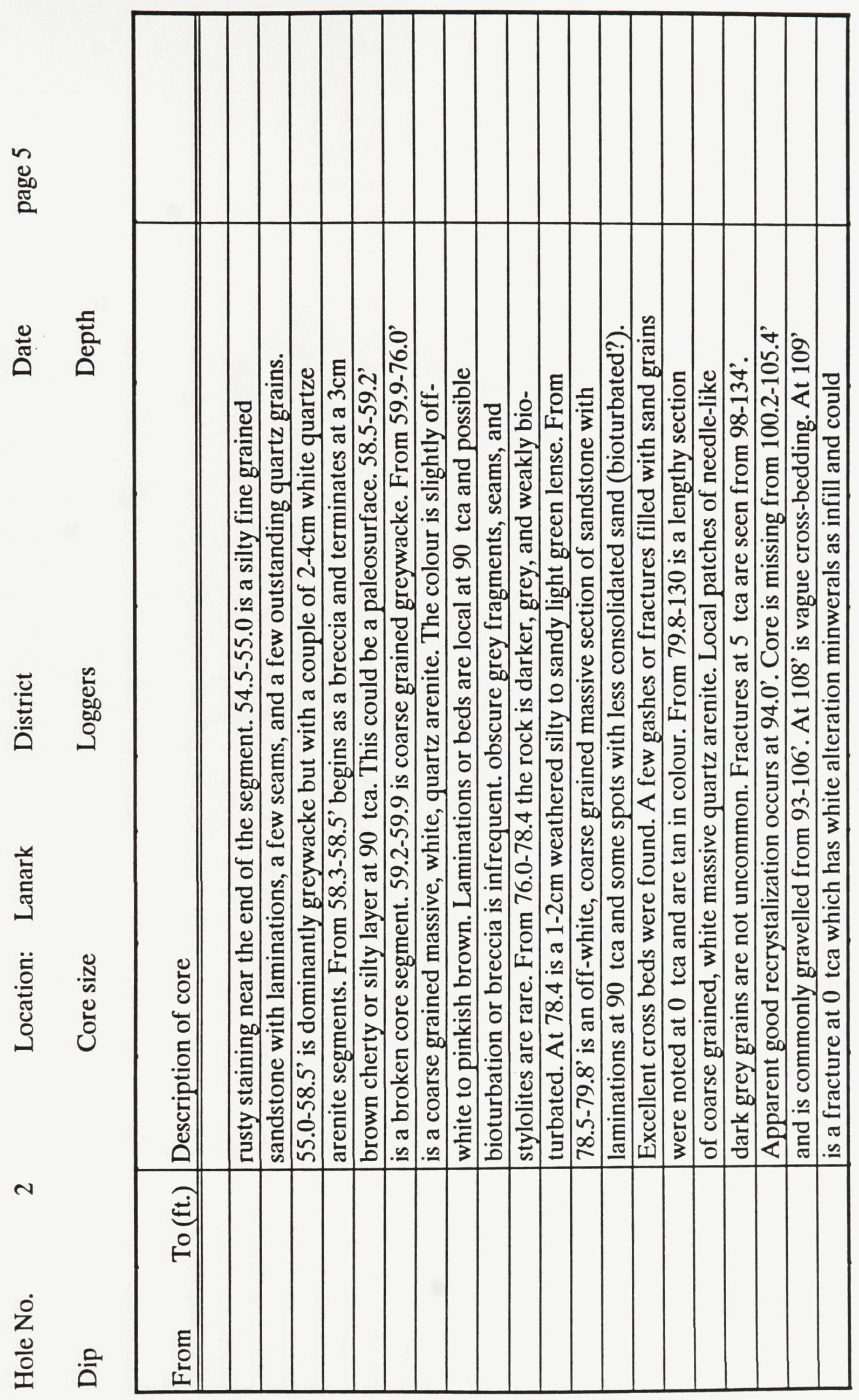




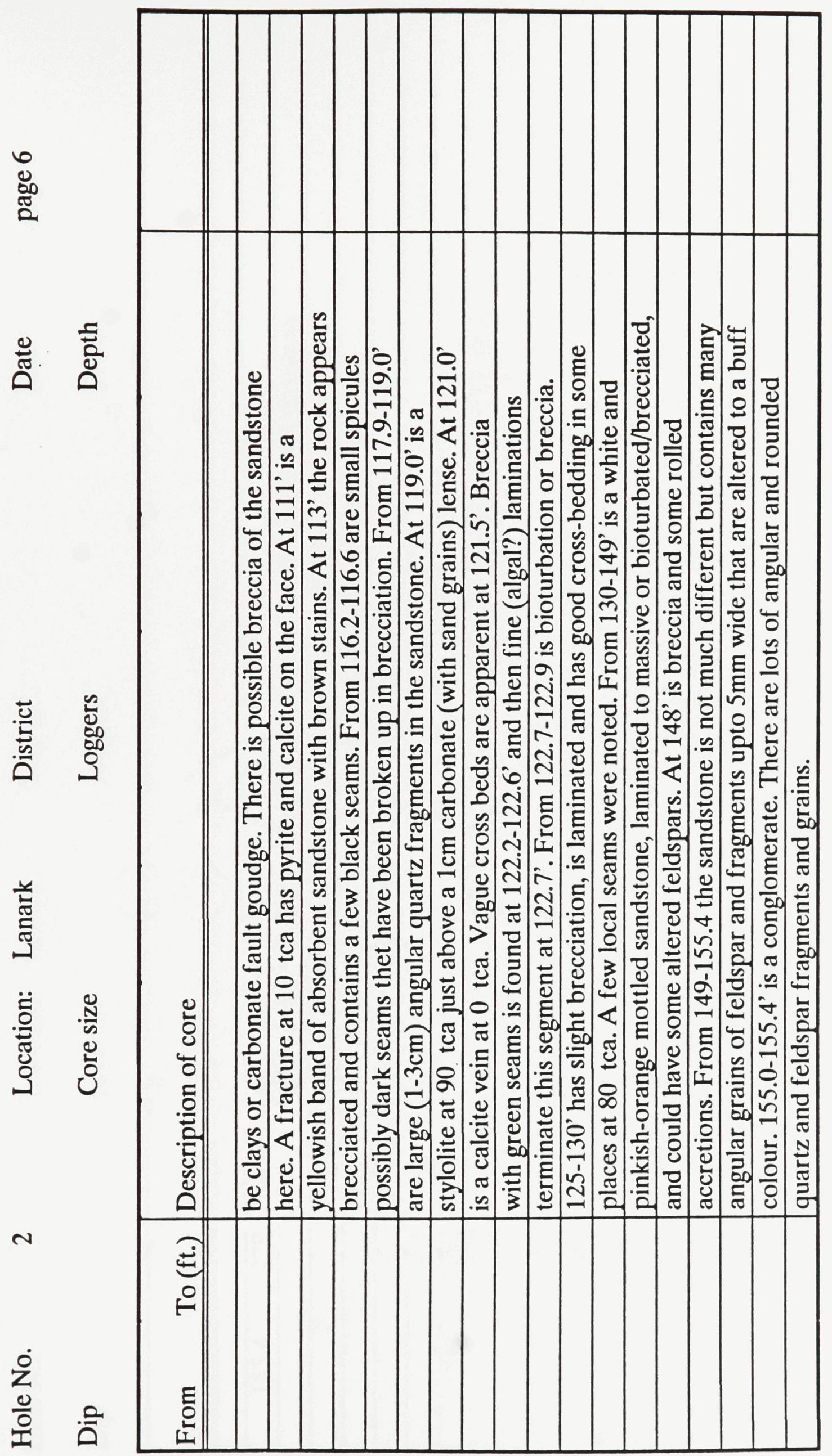




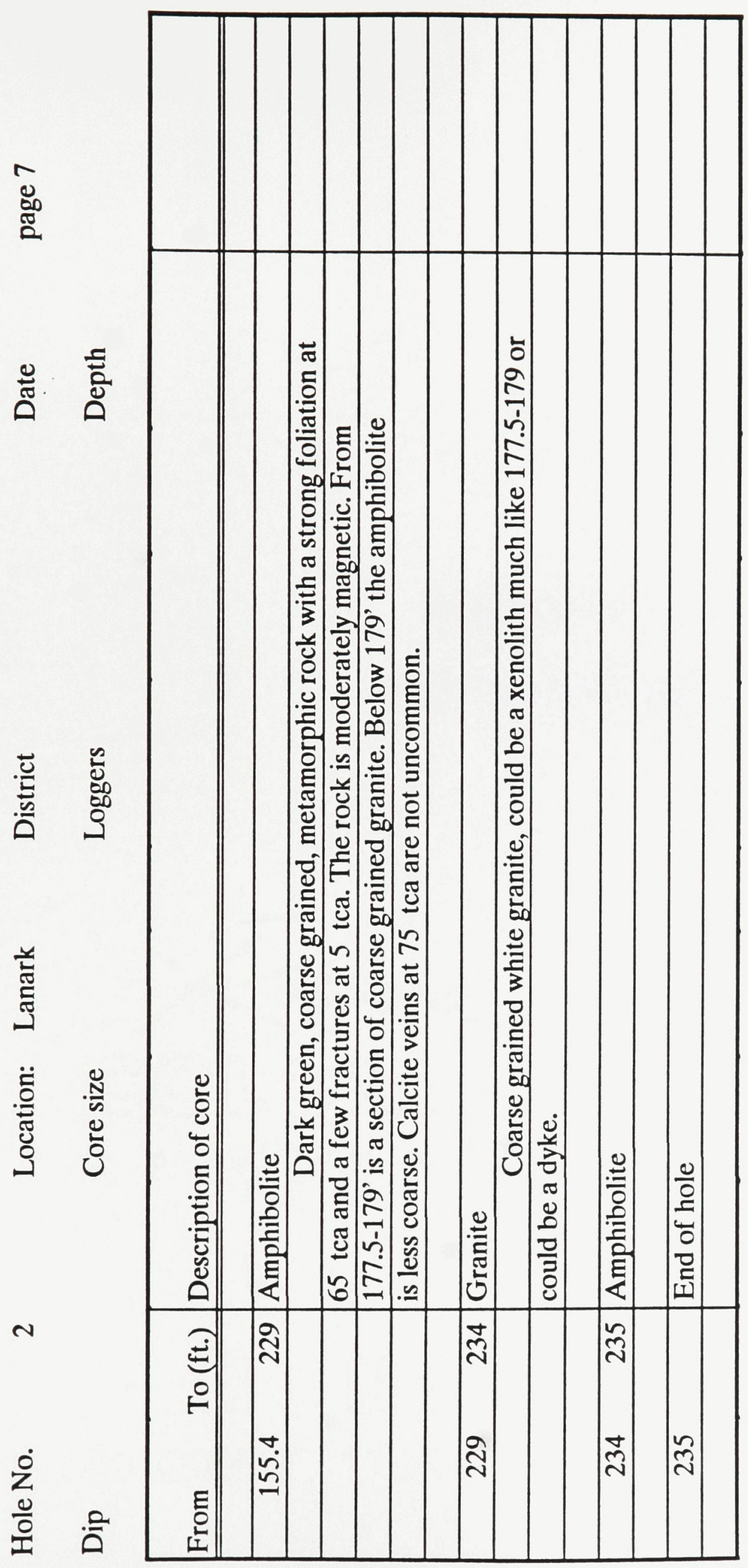


Appendix IV

Drill Hole Sections 


\title{
Lithological Legend
}

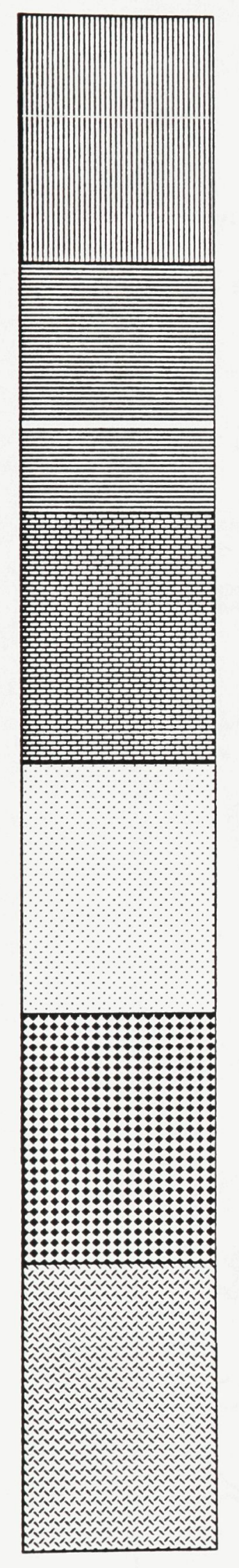

Overburden

Shale

\section{Limestone or Dolomite}

Sandstone

\author{
Amphibolite
}

Granite 
DRILL HOLE SECTIONS

Symbols

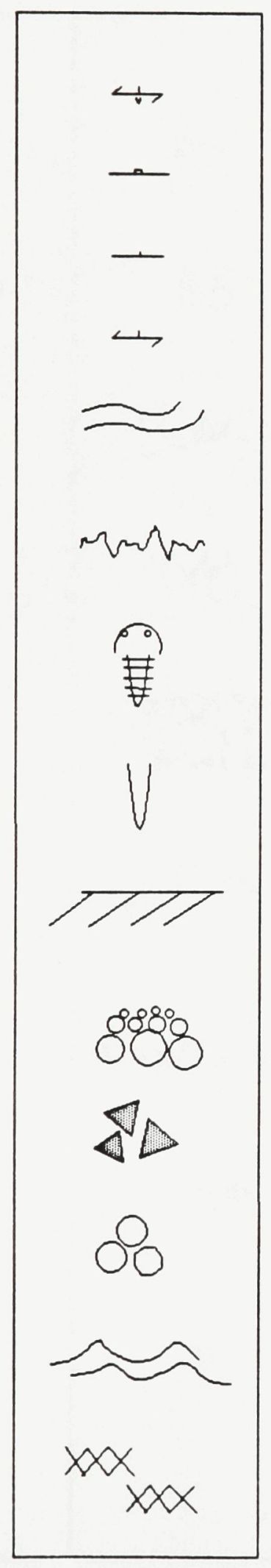

Vein

Jointing

Bedding

Foliation

Seams or laminations

Stylolytes

Fossils

Bioturbation

Cross-bedding

Graded bedding

Brecciation

Conglomerote

Ripples

Massive or crystalline 
DRILL HOLE SECTIONS

Symbols cont'd

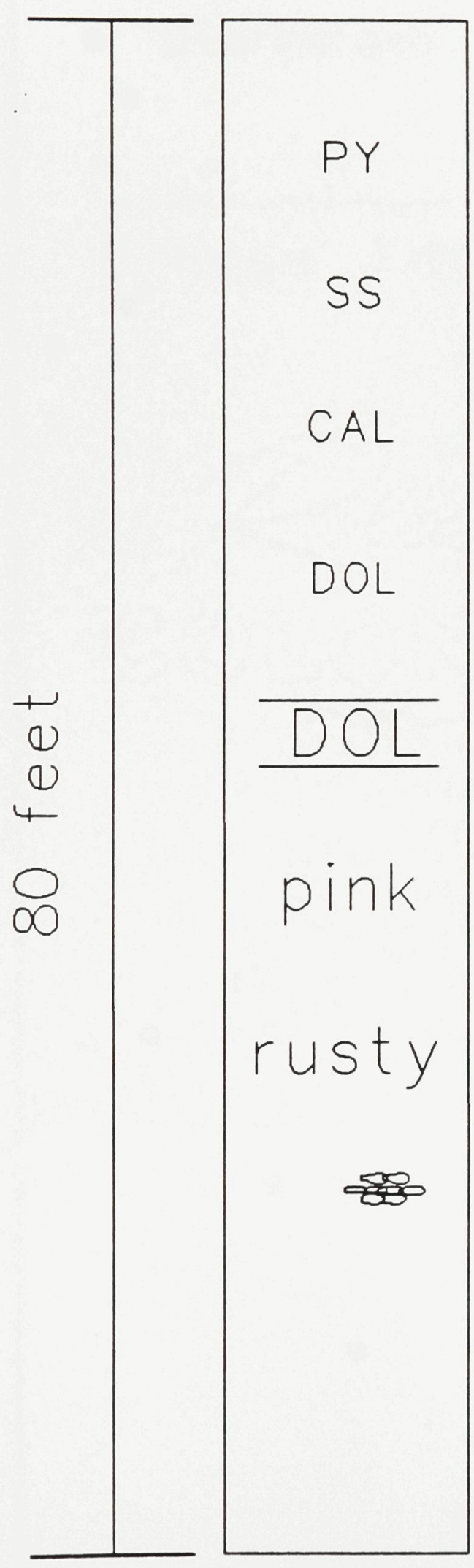

Pyrite mineralization

Sondy section

Calcareous section

Dolomitic section

Lense of dolomite

Pink colourotion

Iron oxide staining

concretions, sphericle nodules

Vertical

Scale... $10 \mathrm{ft}$. to 1 inch 


\section{Drill Hole Billings' Bridge}

Surface

Overburden

Billings' $F m$.
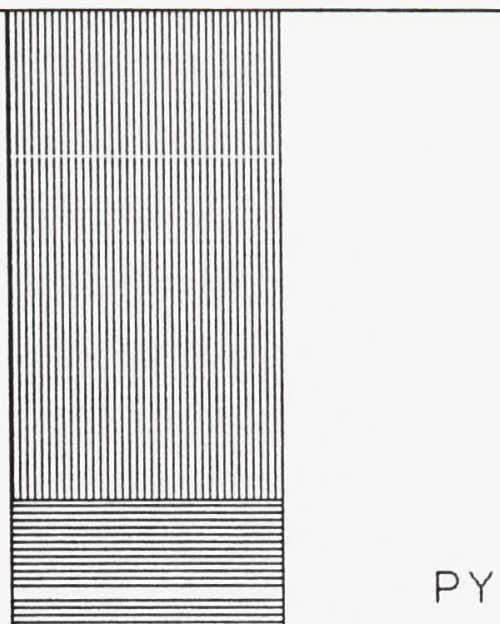

Shale
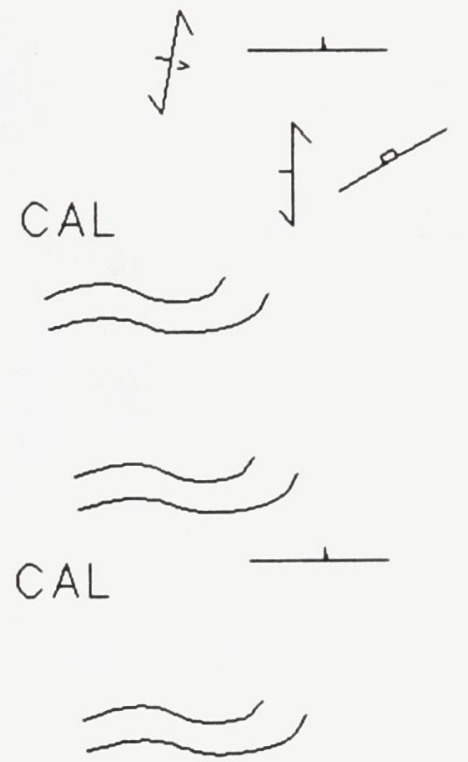

$80^{\prime}$ continued 


\section{Drill Hole Billings' Bridge cont'd ${ }^{182}$} 80 cont'd

Billings' Fm.

Shale

Eastview Fm. Ottawa Group

Cobourg Fm.
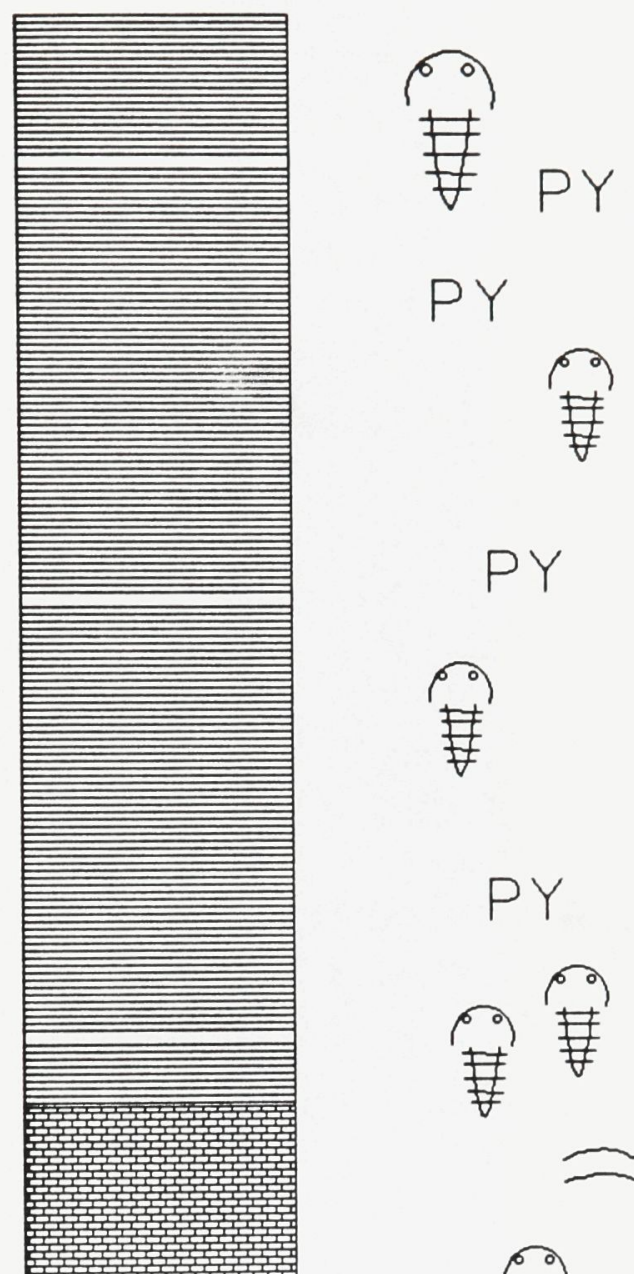

$$
\text { PY }
$$

毒

PY

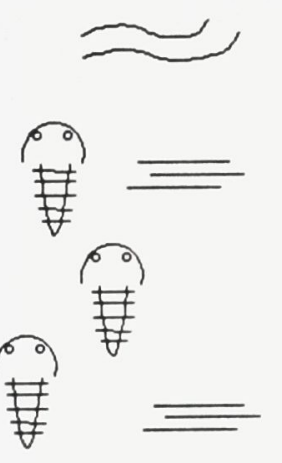

Limestone 


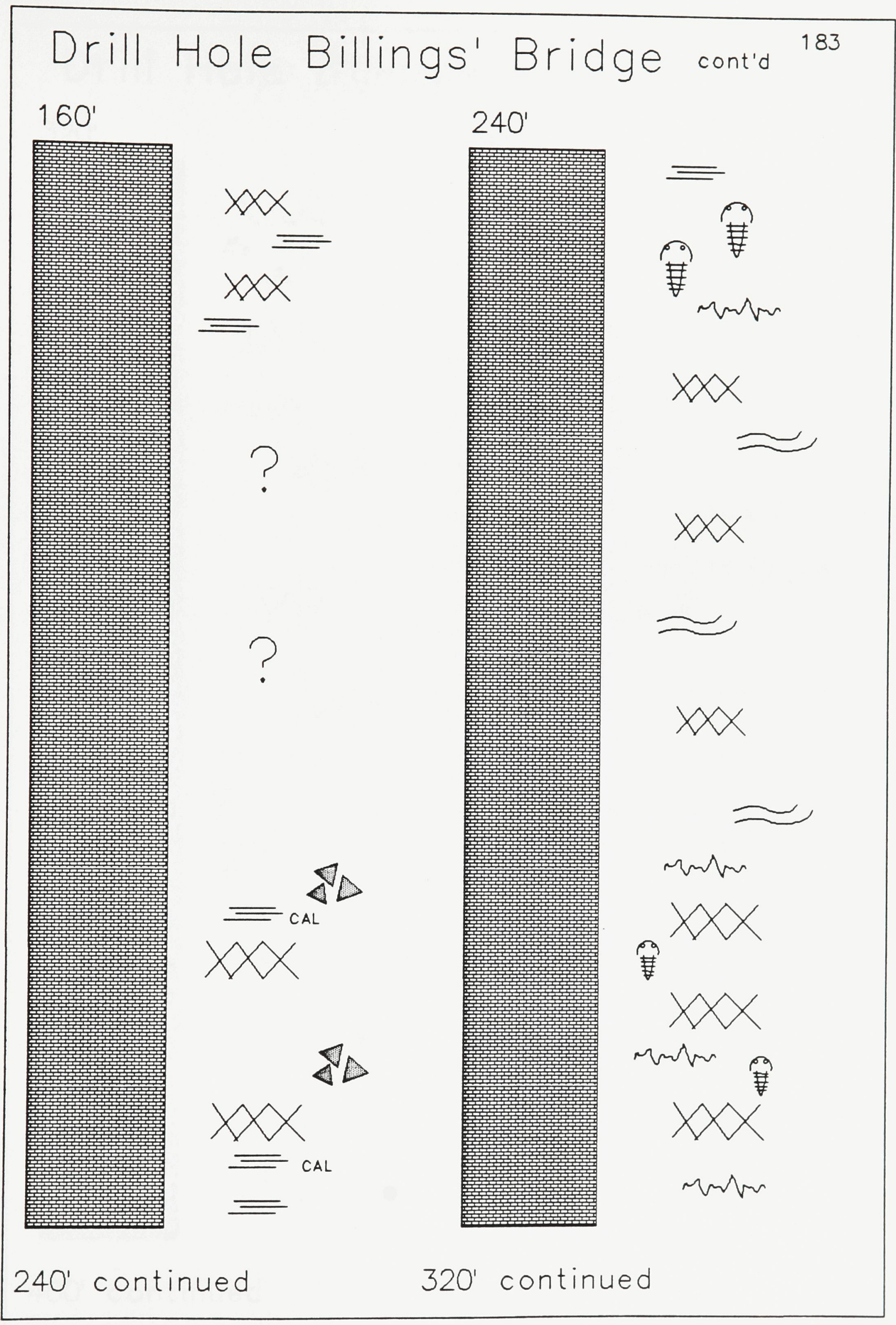




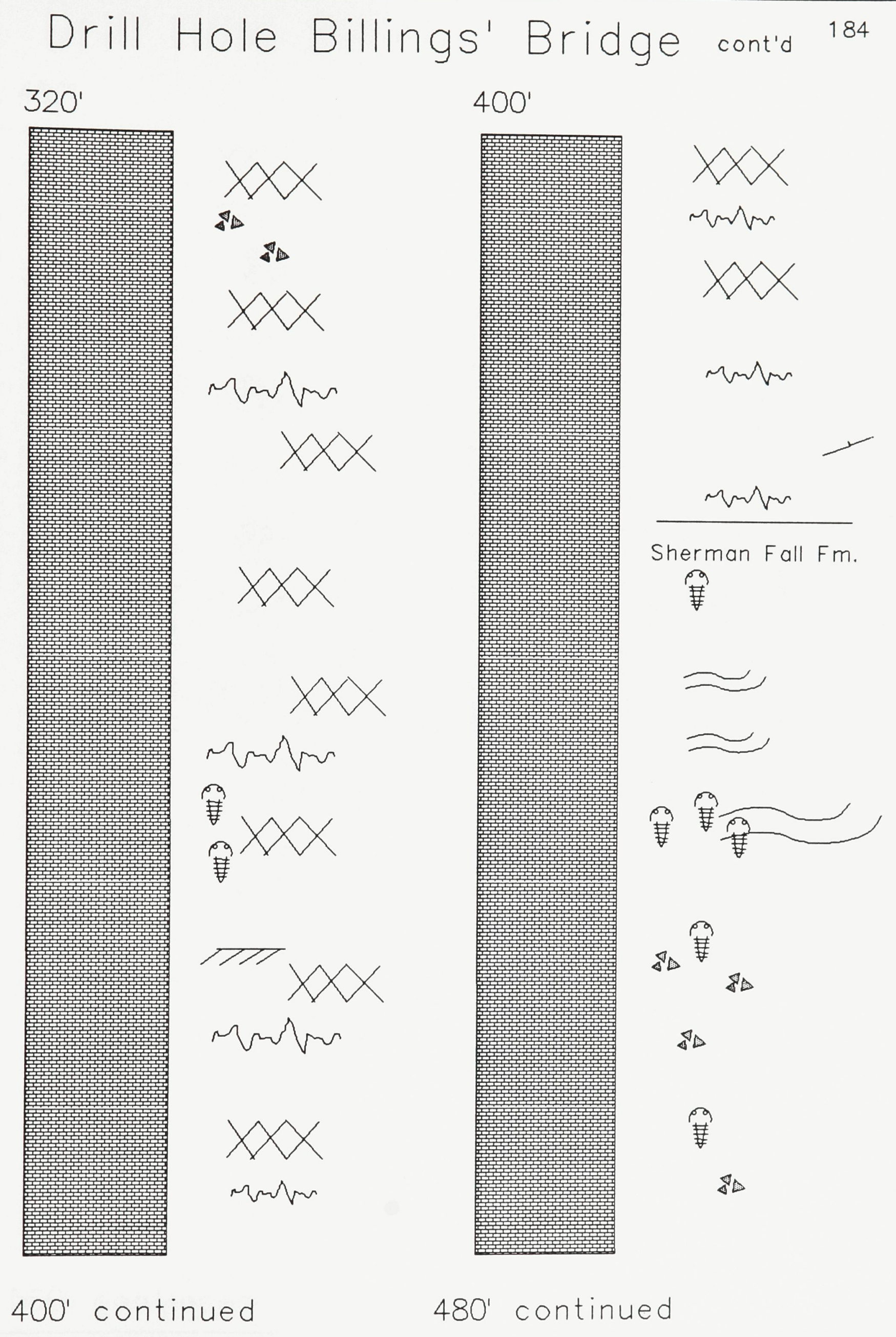




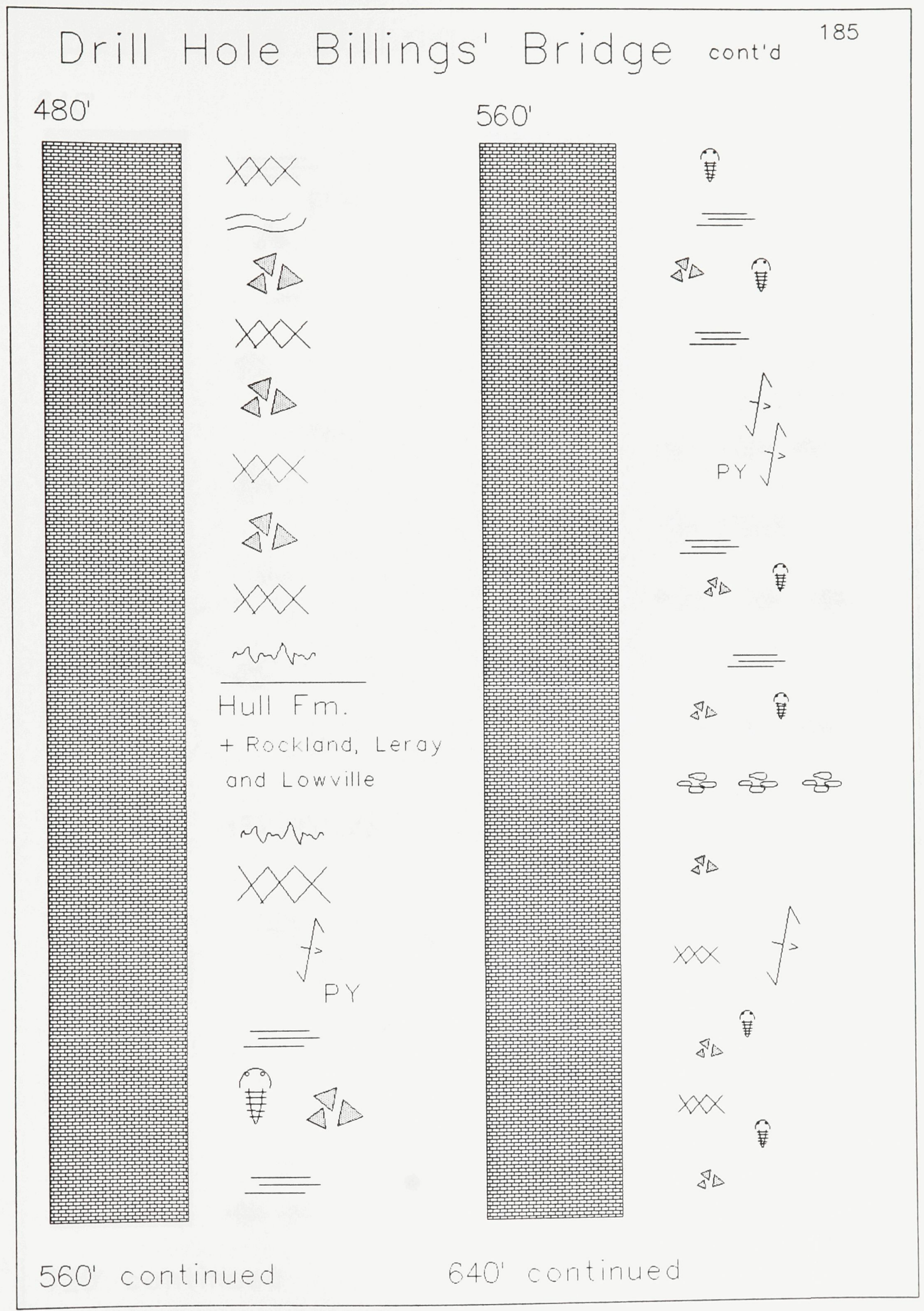




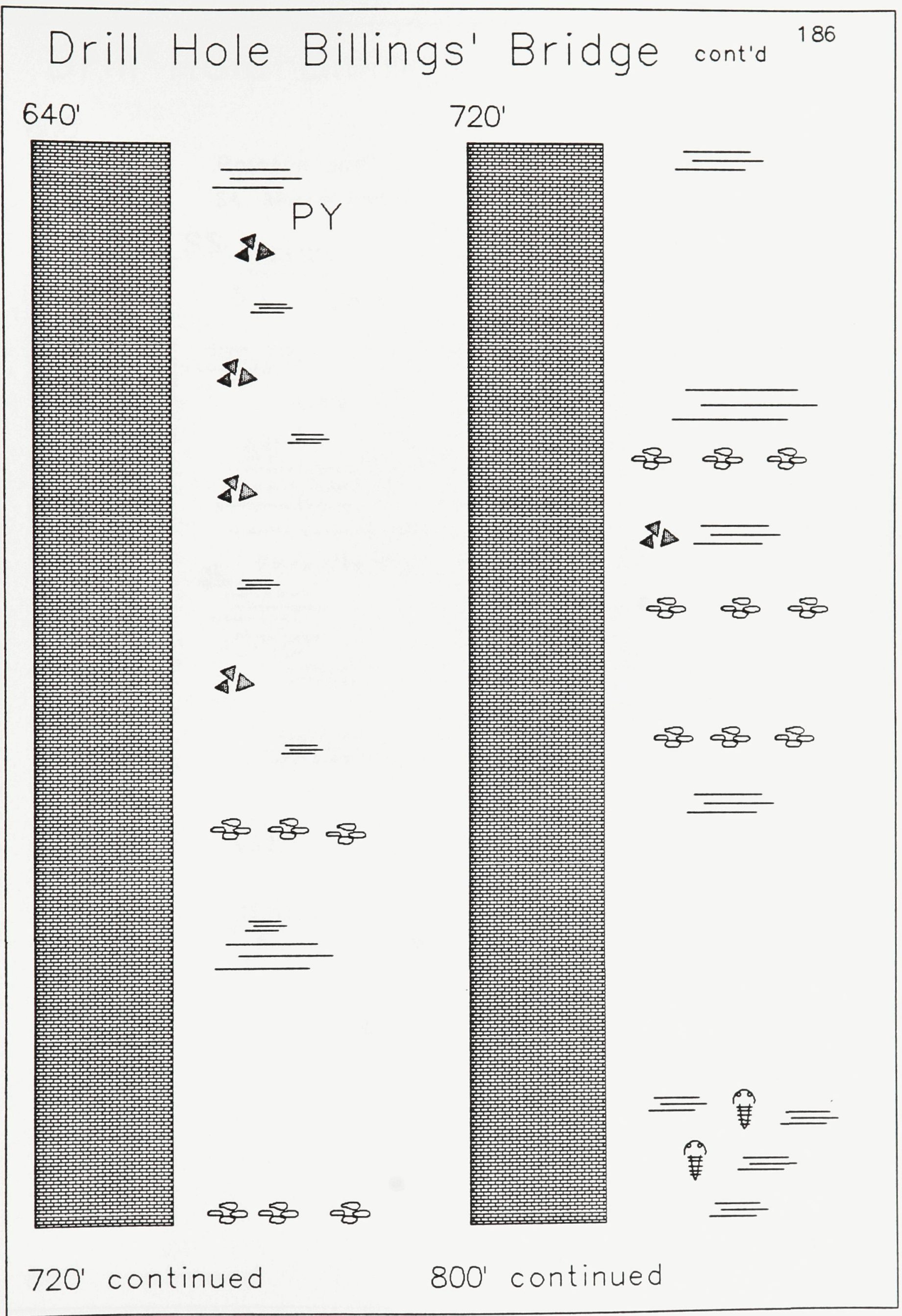




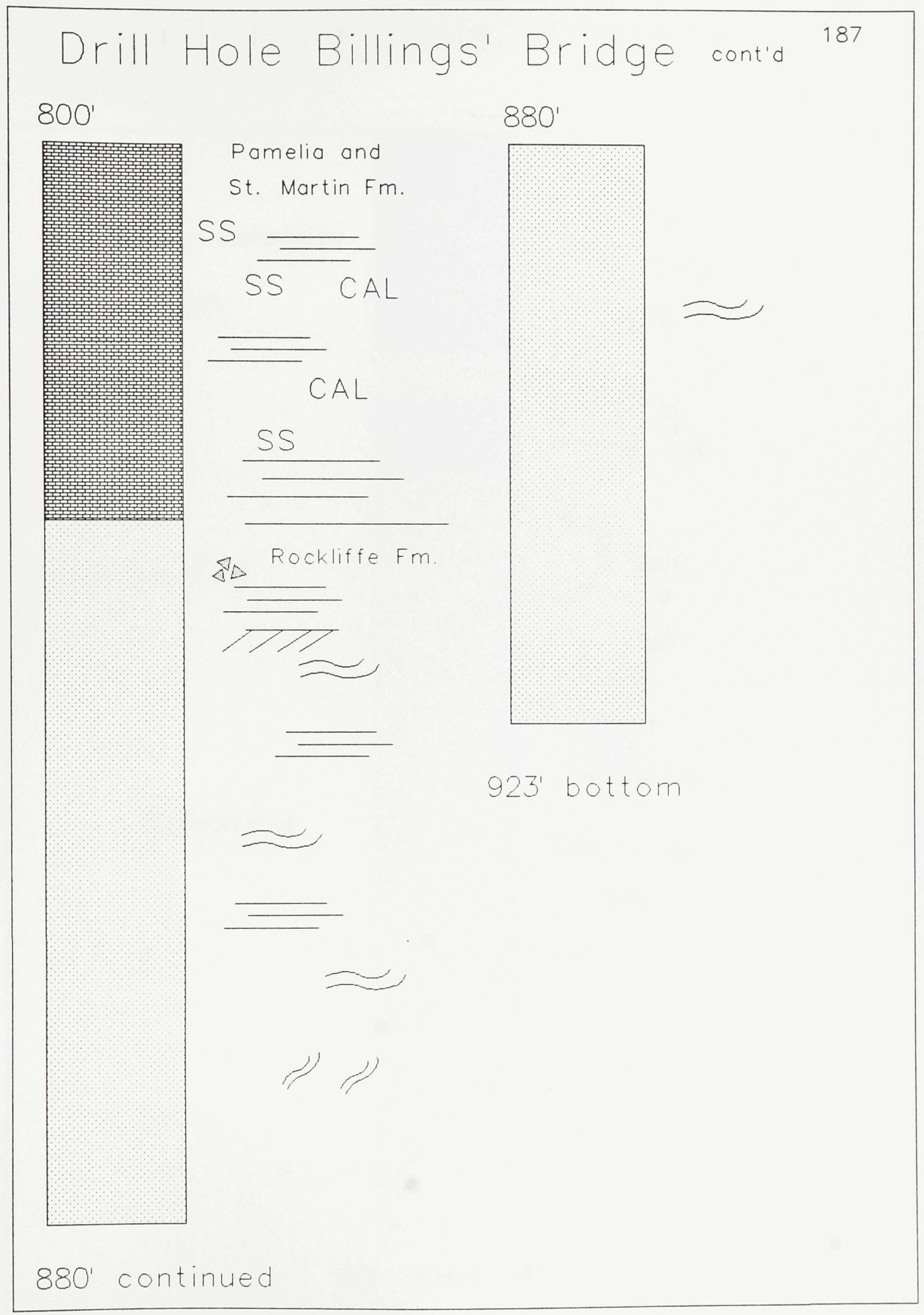




\section{Drill Hole Bells' Corners 188}

Surface

Sandy dolomite

March Fm.

Nepean Fm.

Sandstone

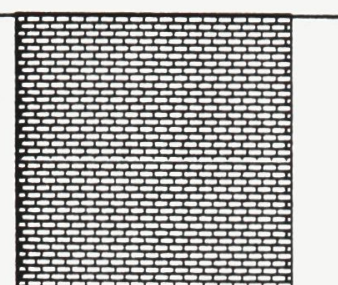

$C A L$

$V_{V \text { maner }} \approx$

rantur

$C A L$

monind

V V

$x \times x$

$x \times x$

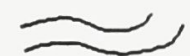

rusty
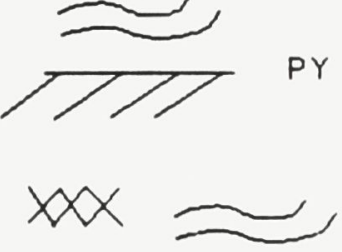

$x x x$

$x \times x$

$x x$

$\infty x$

$\infty x$ 
Drill Hole Bells Corners cont'd 189

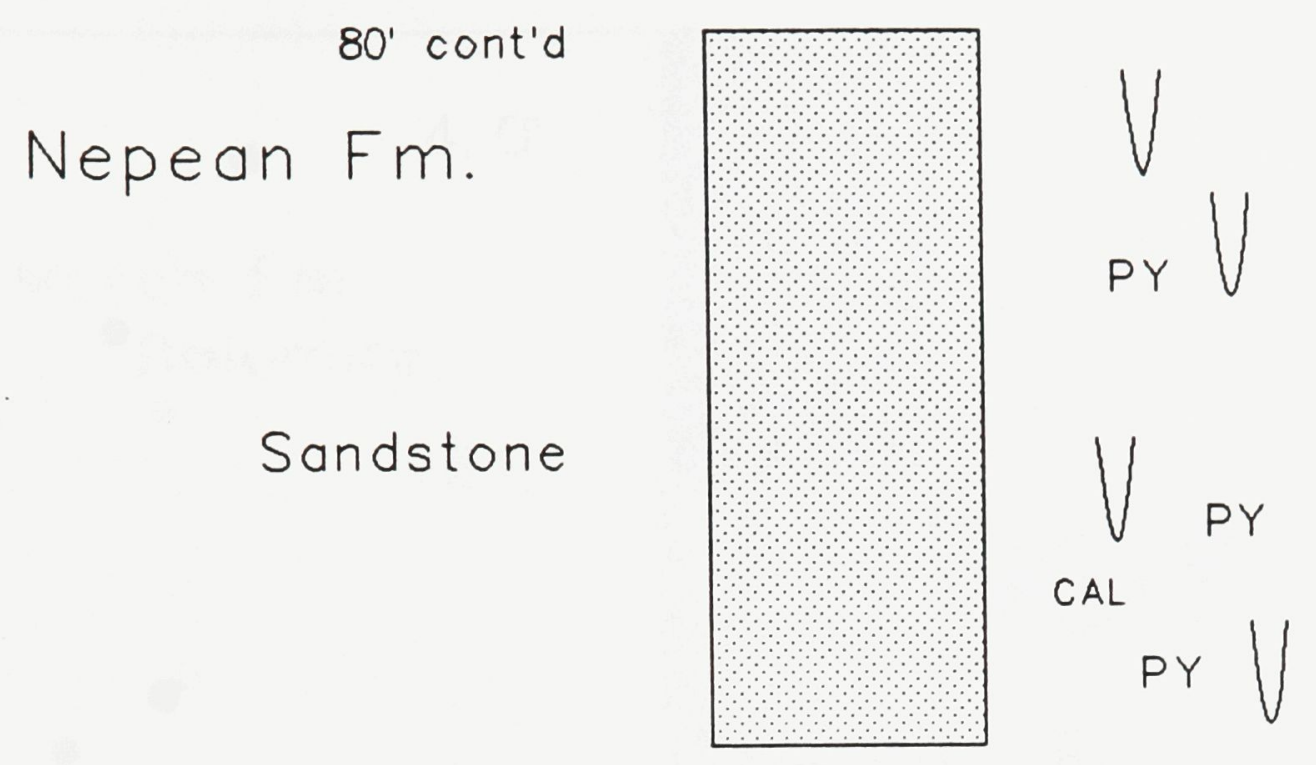

106' bottom 


\section{Drill Hole Lanark 2190}

Surface

March Fm.

Dolomite

4. $0^{\prime}$

16. $0^{\prime}$

Nepean Fm.

\section{Sandstone}

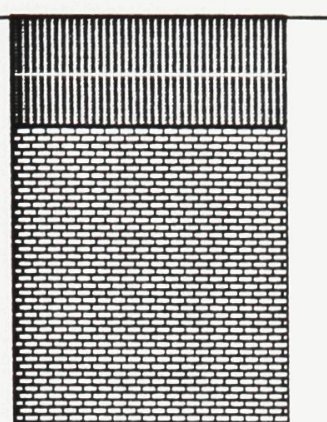

Overburden

$\underset{V_{V}^{U V}}{\widetilde{V U}_{V}}$

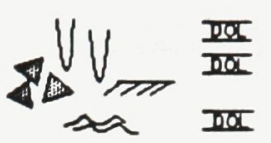

8

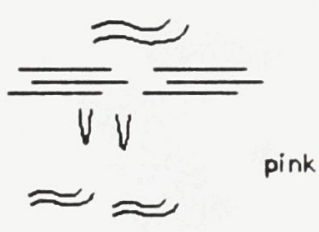

VU

WX

\$D UV rusty

$=$

$W X \begin{gathered}\text { rusty } \\ \text { Py }\end{gathered}$
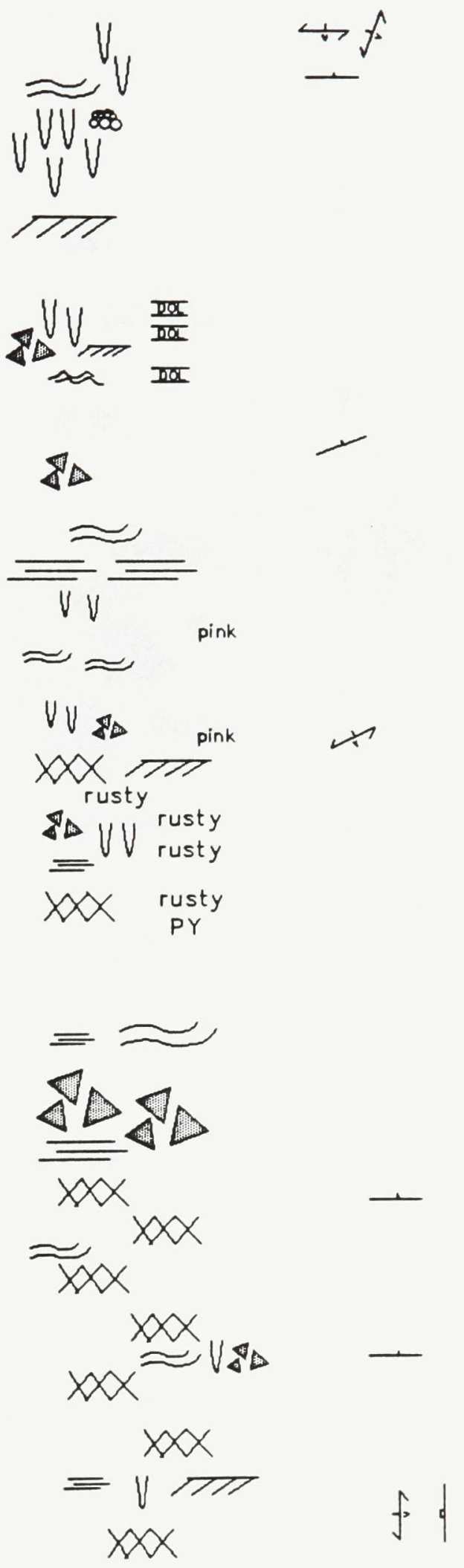

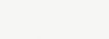
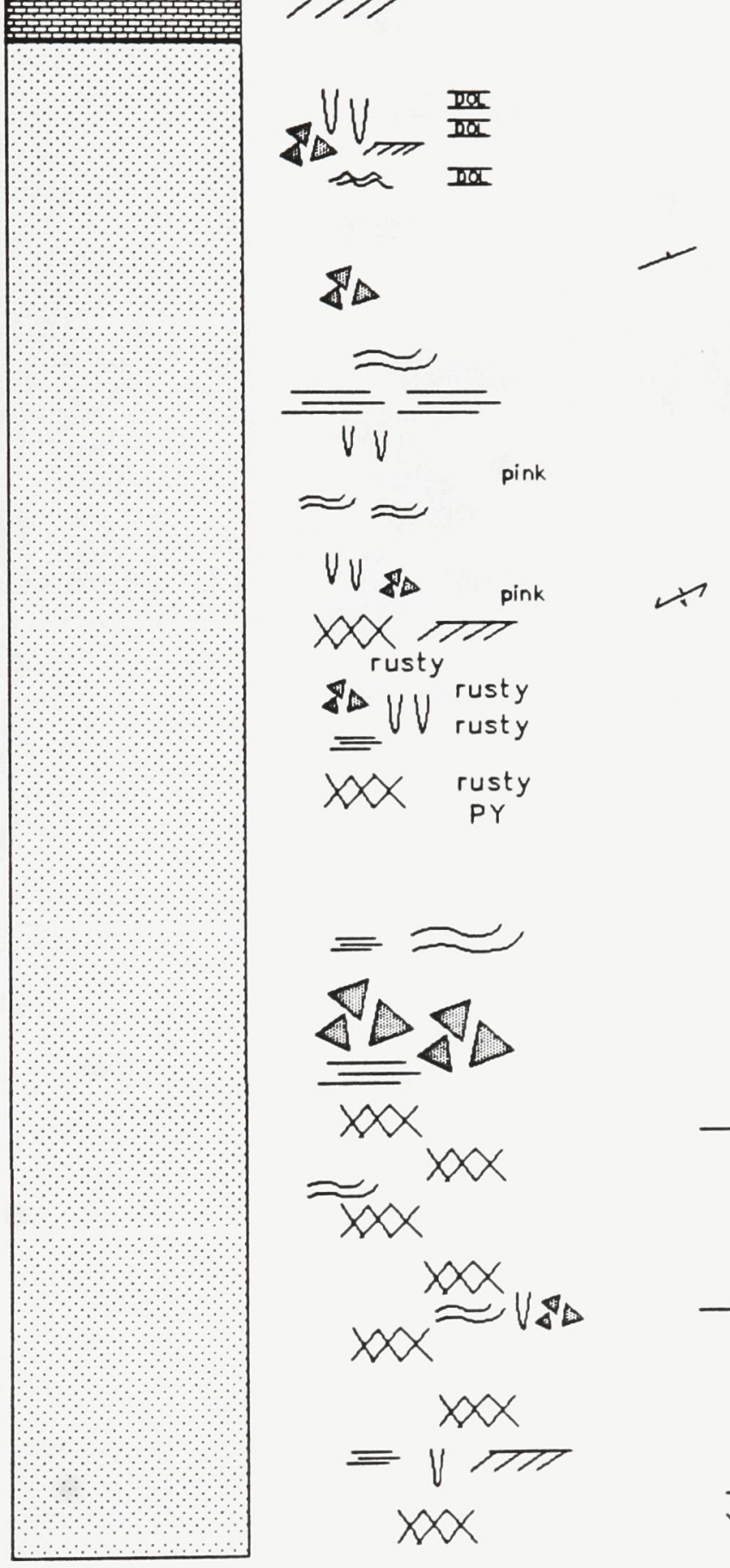

\section{0 continued}




\section{Drill Hole Lanark 2 conto}

80 ' cont'd

Sandstone

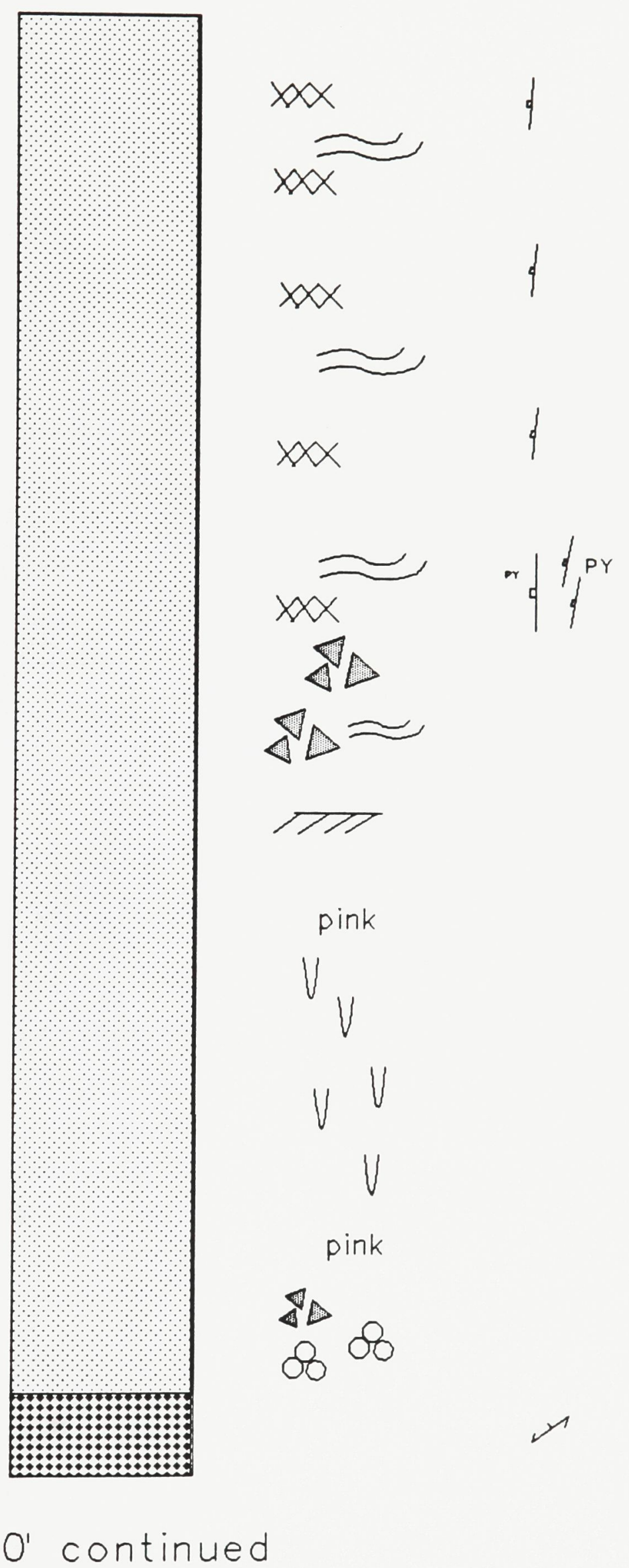


$160^{\prime}$ cont'd

Amphibolite

Gronite

Amphibolite

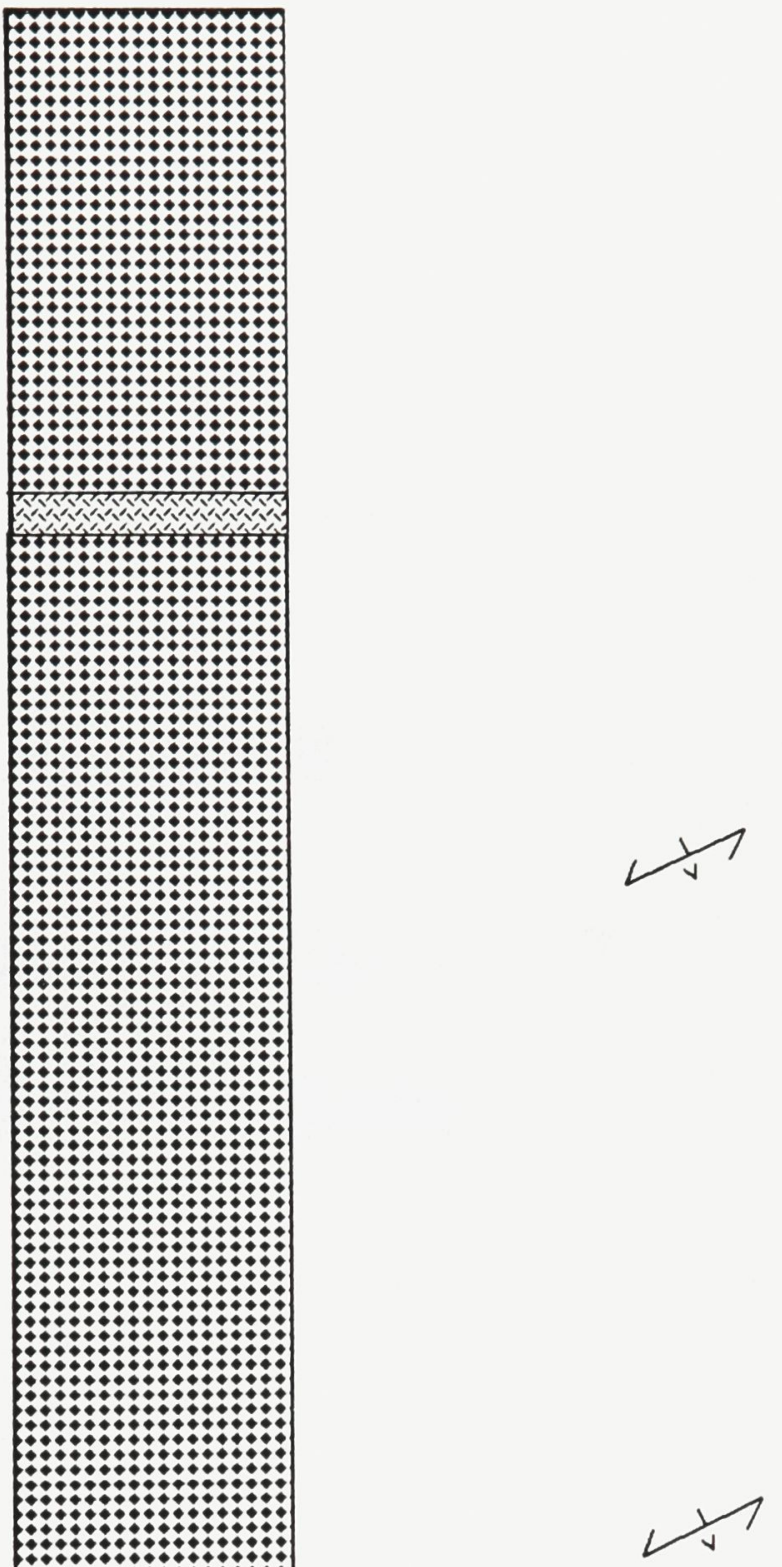

Granite

Amphibolite 
Appendix V

\author{
Building Plans \\ and \\ Bells Corners Quarry
}




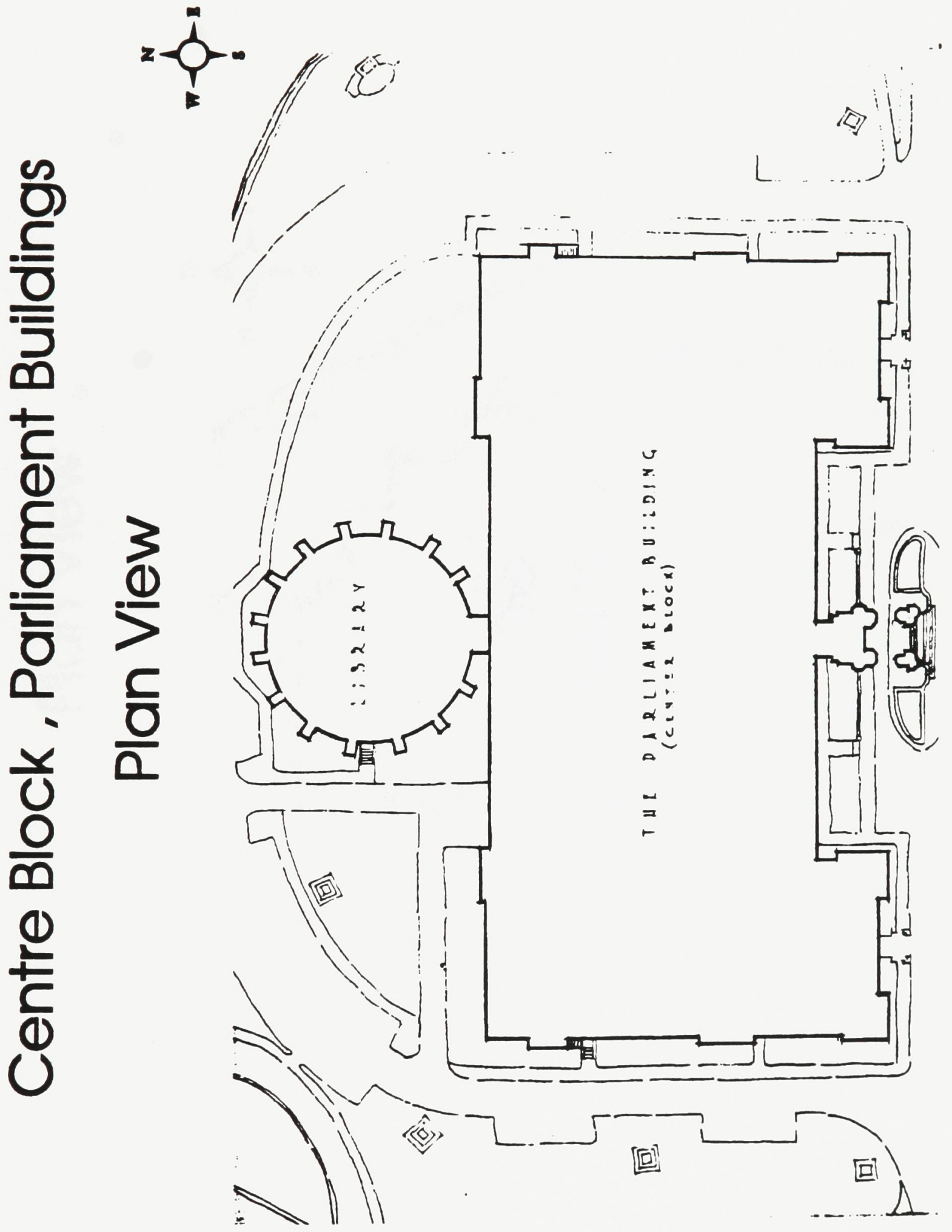



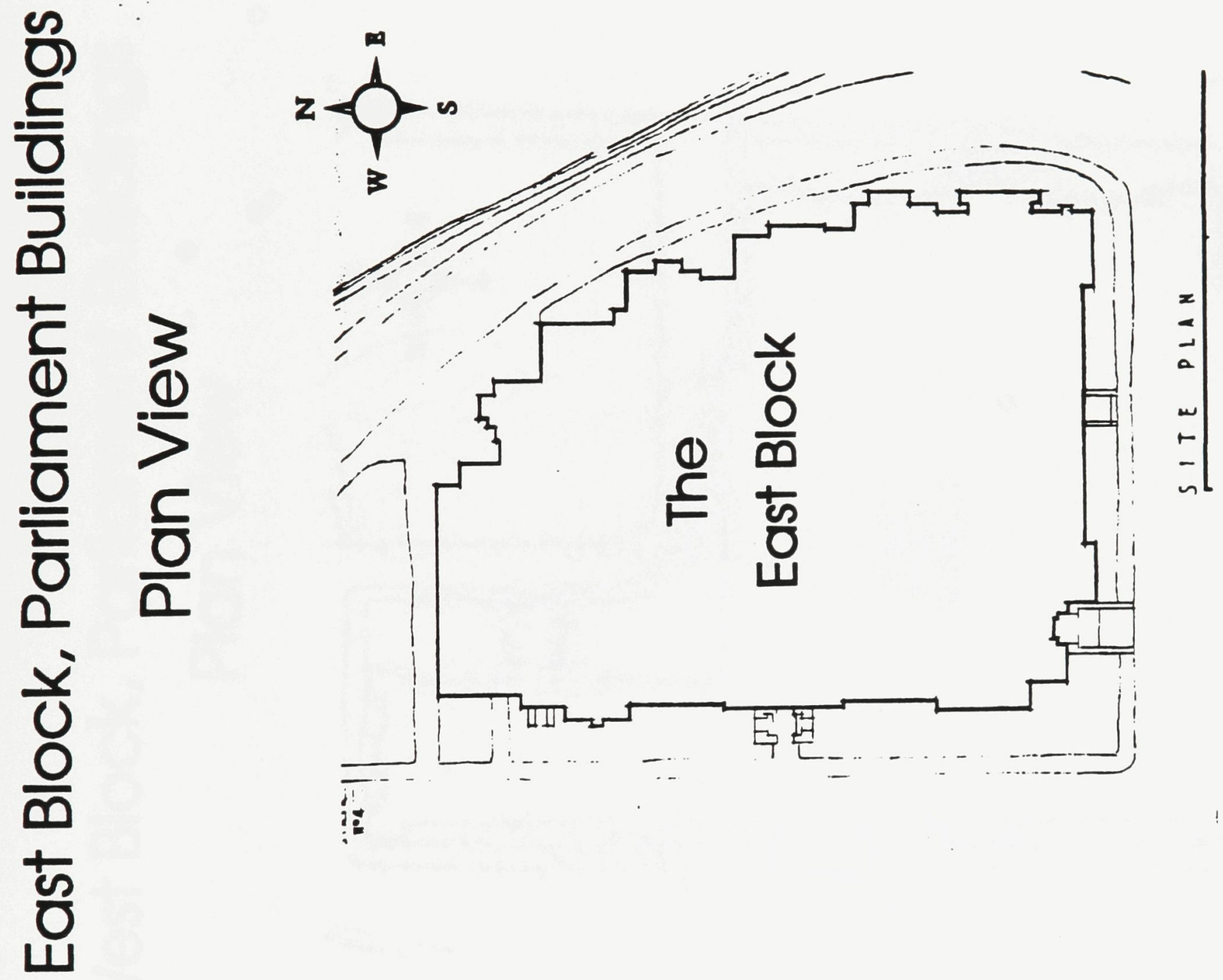

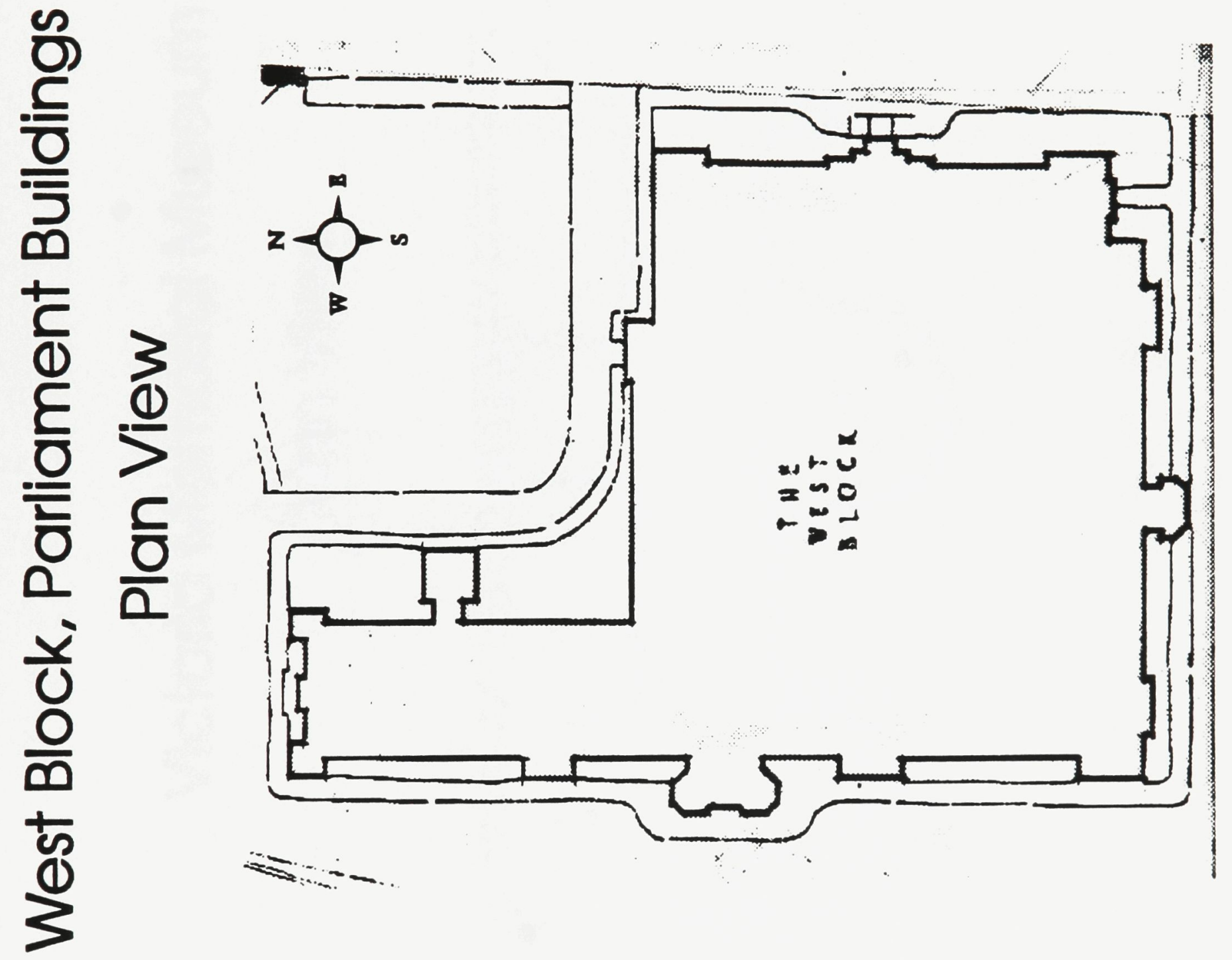


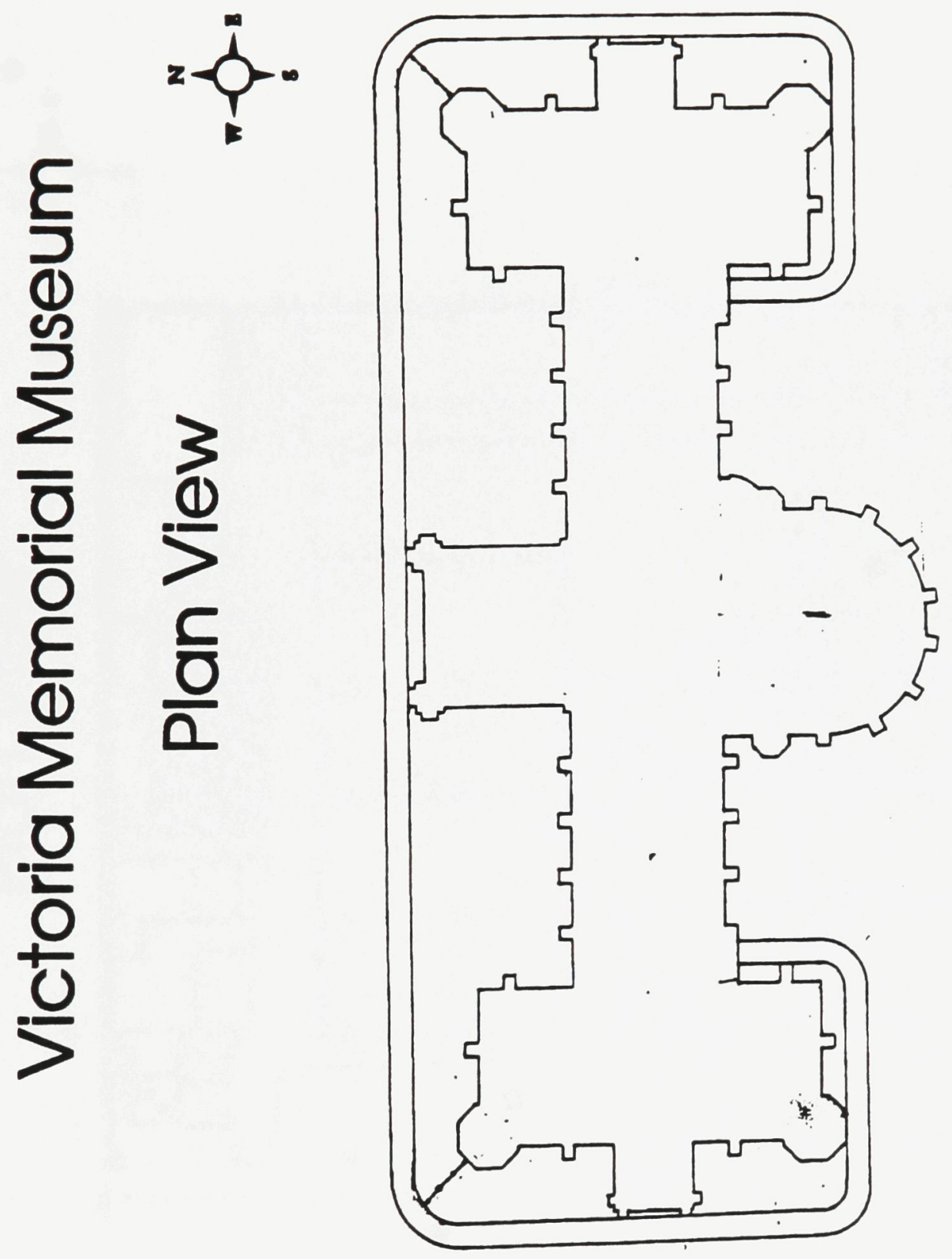




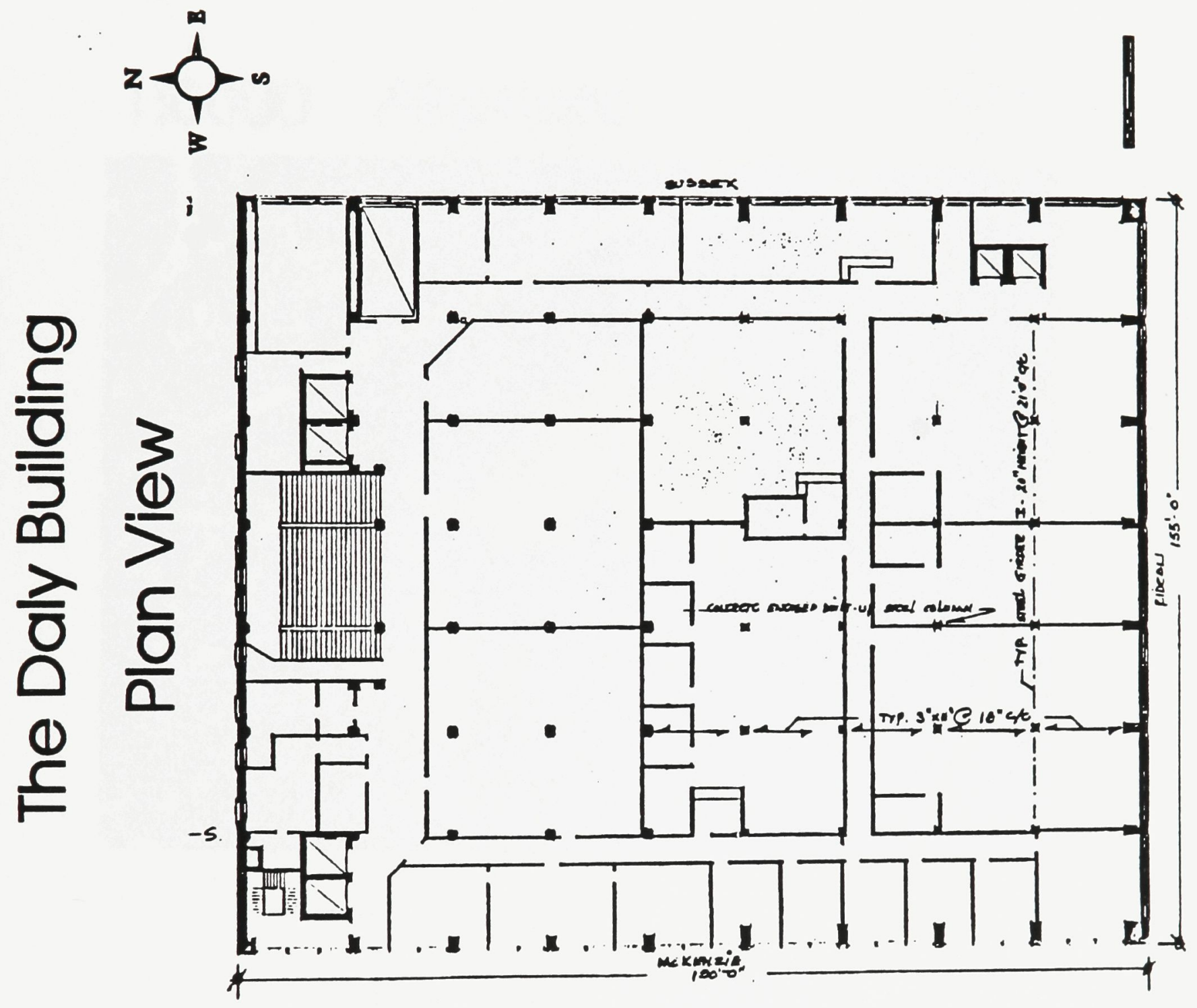




\section{Bells Corners (CANMET) Quarry}
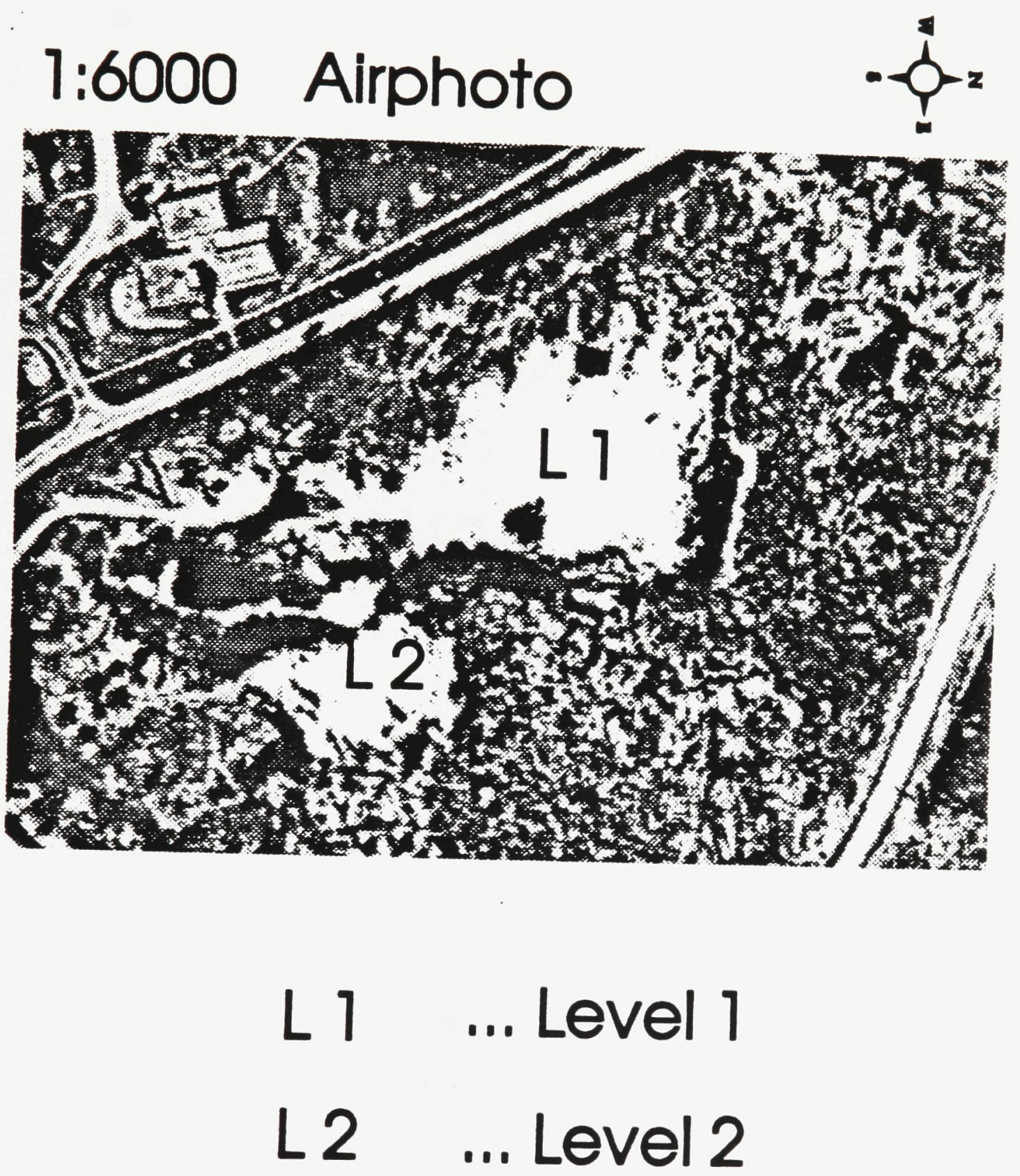